\title{
The mannose receptor, localization and role in the clearance of tissue-type plasminogen activator.
}

\author{
Proefschrift \\ ter verkrijging van de graad van Doctor \\ aan de Rijksuniversiteit te Leiden, \\ op gezag van de Rector Magnificus Dr. W.A. Wagenaar, \\ hoogleraar in de faculteit der Sociale Wetenschappen, \\ volgens besluit van het College van Dekanen \\ te verdedigen op donderdag 23 oktober 1997 \\ te klokke 15.15 uur \\ door \\ Femia Noorman \\ geboren te Hengelo in 1966
}


Promotiecommissie:

Promotor: $\quad$ Prof. dr. P. Brakman

Copromotor: $\quad$ Dr. D.C. Rijken (Gaubius Laboratorium, TNO Prevention and Health)

Referent: Prof. dr. Th.J.C. van Berkel

Overige leden: Prof. dr. A.F. Cohen

Prof. dr. C.D. Dijkstra (Vrije Universiteit, Amsterdam)

ISBN $\quad 90-5412-037-1$

The studies presented in this thesis were performed at the Gaubius Laboratory of TNO-PG, Leiden, at the division of Biopharmaceutics of the Leiden/Amsterdam Center for Drug Researcil, Leiden, and at the department of Pathology, Slotervaart Hospital, Amsterdam. This work was financially supported by the Netherlands Heart Foundation (Grant 90.294) and the "Leiden-Leuven Research stichting".

Financial support by the Gaubius Laboratory of TNO-PG and the Netherlands Heart Foundation for the publication of this thesis is gratefully acknowledged. Financial support obtained from the "Dr. Ir. J.H. van der Laar Stichting" is much appreciated.

Cover illustration: modified picture of the mannose receptor expression in the liver, for original picture see page 152. 


\section{Stellingen behorende bij het proefschrift: The mannose receptor, localization and role in the clearance of tissue-type plasminogen activator.}

1 De identiteit, de hoeveelheid en de onderlinge afstand van de eindstandige suikergroepen bepalen de affiniteit van een ligand voor de mannose receptor (dit proefschrift).

2 Het remmende effect van receptor liganden op de afbraak van weefseltype plasminogeenactivator $(t-P A)$ door macrofagen in vitro is een goede indicatie voor het remmende effect van deze liganden op de afbraak van t-PA in vivo (dit proefschrift).

3 Het aantal receptoren op de celmembraan van de humane macrofaag dat in staat is om monoclonaal antilichaam 15-2 tegen de mannose receptor te binden weerspiegelt het activatietype van de macrofaag (dit proefschrift).

4 Als de variabiliteit in leverdoorbloeding bij patienten met een hartinfarct een rol speelt bij het risico op bloedingen bij thrombolytische therapie met t-PA (A. de Boer, proefschrift, Leiden 1990), dan kunnen stoffen die de interactie tussen t-PA en de mannose receptor blokkeren gebruikt worden om dit risico te reduceren (dit proefschrift).

5 De term "niet-specifieke afweer" is onjuist gezien de grote rol van specifieke suikerherkenning bij dit proces (Malhorta et al., Nature Medicine 1995; 1: 237-43, Prigozy et al. Immunity 1997; 6: 187-97, Jullien et al. J. Clin. Invest. 1997; 99: 2071-74).

6 Als immuunziektes zoals reumatoïde arthritis en de ziekte van Crohn veroorzaakt worden door langzaam delende bacteriën dan zouden deze ziektes niet behandeld moeten worden met middelen die de afweer onderdrukken (Rook et al. Immunology Today 1992; 13: 160-4).

7 De waarneming dat hersenschade vaker voorkomt bij (ex)professionele boksers dan bij (ex)amateurboksers (Jordan et al. JAMA 1997; 278: 136-140) roept de vraag op wat er eerder was, de hersenschade of de behoefte om professioneel te boksen.

8 De behoefte om genetische factoren vast te stellen die het risico op ongezondheid door slechte leefgewoontes vergroten, wordt bepaald door de wens om zoveel mogelijk slechte leefgewoontes in stand te houden.

9 Wanneer een placebo een genezende werking heeft, dient de rol van emoties bij de desbetreffende ziekte en/of het genezingsproces nader onderzocht te worden.

10 Het verschil tussen een gezond en een ziek persoon is dat alleen de zieke persoon zeker is van zijn toestand.

11 Aangezien de aarde het enige is wat ons allen bindt, zouden we de aarde niet moeten verdelen. 
Wherever there is mind, there is body, and wherever body, mind

Hieronymus David Gaubius (1705-1780)

(citation from the Essay of 1747, De Regimine Mentis, a translation by L.J. Rather annotated in Mind and Body in Eighteenth Century Medicine, University of California Press, 1965) 



\section{CONTENTS}

Introduction

Chapter 1 Role of carbohydrate in the binding of tissue-type plasminogen activator (t-PA) to the human mannose receptor.

Submitted.

Chapter 2 Degradation of tissue-type plasminogen activator by human monocyte-derived macrophages is mediated by the mannose receptor and by the low density lipoprotein receptor-related protein.

Blood 1995; 86: 3421-3427.

Chapter 3 Monoclonal antibodies against the human mannose receptor that inhibit the binding of tissue-type plasminogen activator. Thrombosis and Haemostasis 1997; 77:718-724.

Chapter 4 Monoclonal antibodies against the human mannose receptor as a specific marker in flow cytometry and immunohistochemistry for macrophages.

Journal of Leukocyte Biology 1997; 61: 63-72.

Chapter 5 Expression of the human mannose receptor under physiological and pathological conditions. An immunohistochemical study using monoclonal antibody 15-2.

Submitted.

Chapter 6 Lysine-based cluster mannosides that inhibit ligand binding to the human mannose receptor at nanomolar concentration.

Journal of Biological Chemistry 1996; 271: 28024-28030.

Chapter 7 Cluster mannosides can inhibit mannose receptor-mediated tissue-type plasminogen activator degradation by both rat and human cells.

Hepatology 1997; in press.

Chapter 8 Inhibition of mannose receptor-mediated clearance of tissue-type plasminogen activator (t-PA) by dextran: a new explanation for its antithrombotic effect.

Thrombosis and Haemostasis 1997; in press.

Chapter 9 General discussion.

Regulation of tissue-type plasminogen activator concentrations by clearance via the mannose receptor and other receptors.

Fibrinolysis \& Proteolysis 1997; in press. 
Samenvatting

Publications

Curriculum Vitae

Nawoord 135

Appendix Coloured figures belonging to chapter 3,5 and 7 


\section{INTRODUCTION}

\section{The mannose receptor, localization and role in the clearance of tissue-type plasminogen activator.}

The human body houses approximately $1 \times 10^{13}$ cells. About 200 different cell types cooperate to create a balanced milieu in which they can survive. Cells create, control and maintain their surroundings by the use of molecular interactions. One way for the cells to maintain the environment is the production of enzymes and inhibitors. These proteins can modify the composition of extracellular structures and/or each other's action depending on their concentrations and localization.

The cells control the concentration of an extracellular protein by regulating its production and/or degradation. The degradation of some proteins can be controlled by the expression of endocytic receptors that specifically recognize and bind these molecules (ligands). After a molecule is bound to an endocytic receptor it is usually internalized and degraded by the cell. The localization of these ligands depends on the localization of the ligand-producing cells, the transport of the ligands through the body after release, and the localization of the cells that express the endocytic receptors.

A disease is caused by internal (e.g. genetic defects) and/or external (e.g. infection) factors that disturb the balanced environment. We can help the body to recover from a disease by the administration of drug(s). To anticipate the effects of a drug it is important to know its mechanisms of action and the concentrations that are required for these actions. The dosage, administration route, tissue distribution and degradation (clearance) of the drug determine the concentration of the drug at the site of action. Like endogenous ligands, some drugs are cleared by cells after binding to endocytic receptors.

This thesis describes the properties of the mannose receptor which is one of the endocytic receptors that mediate the clearance of an endogenous enzyme called tissue-type plasminogen activator (t-PA), which is also used as a drug. 


\section{The mannose receptor}

The mannose receptor is a $175 \mathrm{kDa}$ type I transmembrane protein that belongs to the C-type lectin family. ${ }^{1}$ The receptor consists of a $\mathrm{N}$-terminal cysteine rich domain, a fibronectin type II domain, eight carbohydrate recognition domains (CRDs), a transmembrane domain, and a C-terminal cytoplasmatic tail $^{2}$ (Fig 1). The receptor has a low affinity for monosaccharides and a high affinity for ligands that bear poly-mannose structures. ${ }^{3}$ The affinity of the ligand probably depends on the number of CRDs it can bind to. ${ }^{4,5}$

Fig 1

Schematic representation of the mannose receptor.

C: Cysteine rich domain, $F_{n}$ : fibronectin type II repeat, eight carbohydrate recognition domains $(1-8)$ with the mannose binding sites (in 4,5 and 7), and a C-terminal transmembrane region with a cytoplasmatic tail).

GP1 represents a glycoprotein with a typical high mannose-type oligosaccharide that is able to bind to the mannose receptor. GP2 represents a glycoprotein with a typical complex-type oligosaccharide that is not able to bind to the mannose receptor. $(\mathrm{O}=\mathrm{N}$-acetylglucosamine, $\boldsymbol{0}=$ mannose, $\square=$ galactose, and $\boldsymbol{\nabla}$ = neuraminic acid) .

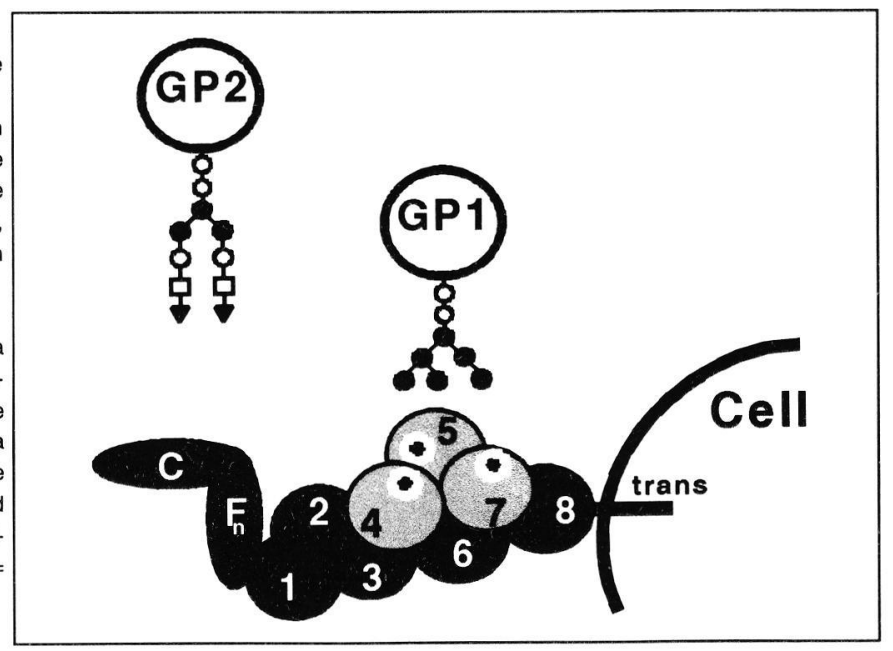

The mannose receptor mediates the endocytosis of glycoproteins bearing high mannose-type oligosaccharides such as lysosomal enzymes ${ }^{6}$ and t-PA ${ }^{7}$ (Fig 2) and the phagocytosis of pathogens carrying poly-mannose structures on their membrane. ${ }^{8}$ After binding the ligand-receptor complex is internalized. Inside the cell the ligand is released in the acid environment of the endosome, the ligand is degraded in the lysosome while the receptor is recycled to the membrane. ${ }^{9,10}$

The $175 \mathrm{kDa}$ mannose receptor has been isolated ${ }^{11-13}$ from human macrophages, liver and placental tissue. Many cell types such as macrophages, ${ }^{9}$ liver and splenic sinusoidal endothelial cells, ${ }^{14,15}$ sperm cells, ${ }^{16}$ airway smooth muscle cells, ${ }^{17}$ lymphocytes and Langerhans cells ${ }^{18}$ have been shown to bind mannose receptor ligands, but they may express other mannose binding proteins or mannose receptorrelated proteins. ${ }^{19-23}$

By use of ligand inhibition studies the $175 \mathrm{kDa}$ mannose receptor has been implicated in the mediation of several processes. In this way it has been shown that the mannose receptor expressed in the liver plays an important role in the clearance of its ligands from the circulation. ${ }^{24}$ The mannose receptor also appears to play an important role in the innate immune system by mediating complement-independent uptake of pathogens ${ }^{8}$ and in the adaptive immune system by the uptake of antigens prior to antigen presentation. ${ }^{25,26}$ Furthermore the mannose receptor may play a role in lymphocyte homing to the spleen, ${ }^{15}$ sperm fertility, ${ }^{16}$ smooth muscle cell proliferation, ${ }^{17}$ and fusion of macrophages into foreign body-type giant cells. ${ }^{27}$ 


\section{Coagulation and fibrinolysis}

After damage to a blood vessel the blood coagulates and a clot is formed, and after tissue repair the clot is degraded. Two processes are involved: coagulation and fibrinolysis. Both processes are cascades of enzymatic reactions; only a few enzymes need to be activated which in turn activate a lot of other enzymes. The coagulation cascade produces thrombin that converts soluble fibrinogen into an insoluble network of fibrin, a main component of a blood clot. The fibrinolytic cascade leads to the production of plasmin that converts fibrin into soluble fibrin degradation products, which results in the dissolution of the blood clot. Coagulation and fibrinolysis are controlled by production and degradation of enzymes and inhibitors. The balance of these processes determines whether the blood clot is formed or degraded. ${ }^{28}$

\section{Tissue-type plasminogen activator (t-PA)}

One of the molecules able to initiate the lysis of the blood clot is t-PA which converts plasminogen into plasmin. t-PA is a $70 \mathrm{kDa}$ serine protease containing five domains; the finger domain, the growth factor domain, kringle 1, kringle 2, and the protease domain. The protein contains three $\mathrm{N}$-linked glycosylation sites $^{29,30}$ (Fig 2). It contains one high mannose-type oligosaccharide on kringle 1 and one complex-type oligosaccharide on the protease domain. Kringle 2 may (type I t-PA) or may not (type II t-PA) contain a complex-type oligosaccharide. Furthermore t-PA is fucosylated in the growth factor domain.

\section{Fig 2}

Schematic representation of tissue-type plasminogen activator (t-PA).

Two views of a model of $t-P A$ showing a hypothetical spatial arrangement of the domains. The finger domain (FD), growth factor domain (GD), Kringle 1 (K1) which is glycosylated with a high mannose-type oligosaccharide $(\mathrm{CH} 1)$, Kringle 2 (K2) which contains the lysine binding site (LBS) and a complex-type oligosaccharide $(\mathrm{CH} 2)$ and the protease domain (PD) which contains the active site (AS) and a complex-type oligosaccharide (CH3) (modified from Opdenakker et al. ${ }^{29}$ ).

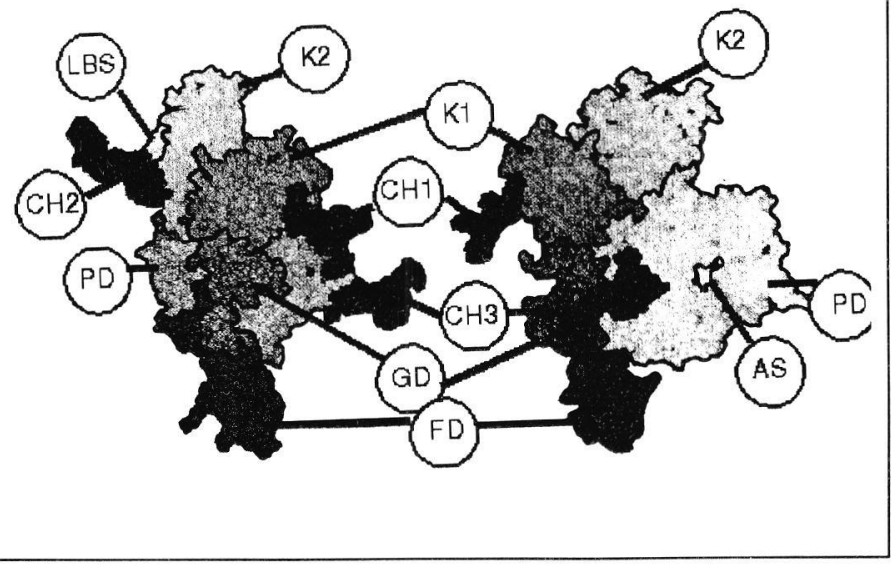

In a healthy situation t-PA circulates in low concentrations in the blood. Synthesis and blood clearance of t-PA as well as inhibition of t-PA by plasminogen activator inhibitor-1 (PAI-1) control the activity of t-PA in blood. The t-PA in the blood is continuously produced by the endothelial cells lining the blood vessels, ${ }^{31}$ and continuously cleared mainly by the liver. ${ }^{32,33}$ The clearance of t-PA is very rapid. Within 5 minutes half of an injected dose of t-PA has disappeared from the blood. The clearance of t-PA is a receptormediated process. The mannose receptor is one of the endocytic receptors expressed in the liver that mediate the clearance of t-PA. ${ }^{7}$ By use of recombinant technology, t-PA can be made outside the body. Recombinant t-PA is successfully used as a drug in thrombolytic therapy ${ }^{34}$ and may be useful in antithrombotic therapy. ${ }^{35}$ 


\section{Aim of this thesis}

The thrombolytic and antithrombotic effect of t-PA depend on its concentration in the blood. The mannose receptor is one of the receptors that mediates the clearance of t-PA from the blood. We hypothesized that by blocking the binding of t-PA to this receptor it might be possible to decrease the clearance of t-PA and thereby increase the efficacy of both endogenous and exogenous t-PA. Inhibitors of the t-PA-mannose receptor interaction may thus be useful drugs in thrombolytic and antithrombotic therapy. The aim of this study was to extend our knowledge of the mannose receptor in order to develop efficient mannose receptor inhibitors. These inhibitors may in the future be used to prevent or to treat thrombotic (and other) diseases.

To study the human mannose receptor-t-PA interaction and to evaluate the efficacy of inhibitors we developed and characterized two in vitro assays (chapter 1 and 2). Monoclonal antibodies against the human mannose receptor were developed as a tool to specifically study the $175 \mathrm{kDa}$ mannose receptor that is able to bind t-PA (chapter 3). To assess the possible role(s) of the mannose receptor in man these monoclonal antibodies were used to evaluate the mannose receptor expression on cells in vitro and in human tissues under physiological and pathological conditions (chapter 4,5). A panel of mannose receptor inhibitors was synthesized and tested for their efficacy to inhibit the interaction of t-PA with the mannose receptor in vitro and the t-PA clearance in vivo (chapter 6,7$)$. To provide evidence for a possible antithrombotic effect of mannose receptor inhibitors in man, we studied the effect of the antithrombotic drug, dextran, on the t-PA-mannose receptor interaction in vitro and its effect on exogenous t-PA clearance and on endogenous t-PA concentrations in vivo (chapter 8 ). The results of this thesis are discussed in the context of the literature concerning t-PA, the mannose receptor and other t-PA clearance receptors (chapter 9).

The main outcomes of this thesis are that the mannose receptor is expressed by few human cell types. The expression of the mannose receptor on macrophages is highly regulated and depends on the type of macrophage activation. The functioning of the mannose receptor in the liver influences t-PA plasma concentrations. Mannose receptor inhibitors inhibit t-PA plasma clearance and thereby increase t-PA plasma concentrations. Thus mannose receptor inhibitors can be considered as a new strategy to increase the t-PA concentration in blood and thereby increase the efficacy of thrombolytic and antithrombotic therapy. 


\section{REFERENCES}

1 Drickamer K, Taylor ME. Biology of animal lectins. Ann Rev Cell Biol 1993; 9: 237-264.

2 Taylor ME, Conary JT, Lennartz MR, Stahl PD, Drickamer $\mathrm{K}$. Primary structure of the mannose receptor contains multiple motifs resembling carbohydrate-recognition domains. J Biol Chem 1990; 265: 2156-12162.

3 Kery V, Krepinsky JJF, Warren CD, Capek P, Stahl PD. Ligand recognition by purified human mannose receptor. Arch Biochem Biophys 1992; 298: 49-55.

4 Taylor ME, Bezouska K, Drickamer K. Contribution to ligand binding by multiple carbohydrate-recognition domains in the macrophage mannose receptor. J Biol Chem 1992; 267: 1719-1726.

5 Taylor ME, Drickamer K. Structural requirements for high affinity binding of complex ligands by the mannose receptor. J Biol Chem 1993; 268: 399-404.

6 Stahl PD, Somsel Rodman J, Miller MJ, Schlesinger PH. Evidence for receptor-mediated binding of glycoproteins, glycoconjugates, and lysosomal glycosidases by alveolar macrophages. Proc Nat Acad Sci USA 1978; 75: 13991403.

7 Rijken DC, Otter M, Kuiper J, van Berkel ThJC. Receptormediated endocytosis of tissue-type plasminogen activator (t-PA) by liver cells. Thromb Res 1990; suppl X: 63-71.

8 Ofec I, Goldhar J, Keisari Y, Sharon N. Nonopsonic phagocytosis of microorganisms. Annu Rev Microbiol 1995; 49: 239-276.

9 Stahl P, Schlesinger PH, Sigardson E, Rodman JS, Lee YC. Receptor-mediated pinocytosis of mannose glycoconjugates by macrophages: characterization and evidence for receptor recycling. Cell 1980; 19: 207-215.

10 Wileman T, Boshans RL, Schlesinger P, Stahl P. Monensin inhibits recycling of macrophage mannoseglycoprotein receptors and ligand delivery to lysosomes. Biochem J 1984; 220: 665-675.

11 Haltiwanger RS, Hill RL. The ligand binding specificity and tissue localization of a rat alveolar macrophage lectin. J Biol Chem 1986; 261: 15696-15702.

12 Otter M, Zockova P, Kuiper J, van Berkel ThJC, BarrettBergshoeff MM, Rijken DC. Isolation and characterization of the mannose receptor from human liver potentially involved in the plasma clearance of tissue-type plasminogen activator. Hepatology 1992; 16: 54-59.

13 Lennartz MR, Cole FS, Shepherd VL, Wileman TE, Stahl PD. Isolation and characterization of a mannose-specific endocytosis receptor from human placenta. $J$ Biol Chem 1987; 262: 9942-9944.

14 Maynard Y, Baenziger JU. Oligosaccharide specific endocytosis by isolated rat hepatic reticuloendothelial cells. J Biol Chem 1981; 256: 8063-8068.

15 Weston SA, Parish CR. Evidence that mannose recognition by splenic sinusoidal cells plays a role in the splenic entry of lymphocytes. Eur J Immunol 1992; 22: 1975-1981.

16 Benoff S, Hurley I, Cooper GW, Mandel FS, Hershlag A,
Scholl GM, Rosenfeld DL. Fertilization potential in vitro is correlated with head-specific mannose-ligand receptor expression, acrosome status and membrane cholesterol content. Hum Repr 1993; 8: 2155-2166.

17 Lew BD, Songu-Mize E, Pontow SE, Stahl PD, Rattazi MC. A mannose receptor mediates mannosyl-rich glycoprotein-induced mitogenesis in bovine airway smooth muscle cells. J Clin Invest 1994; 94: 1855-1863.

18 Reis e Sousa C, Stahl PD, Austin JM. Phagocytosis of antigens by Langerhans cells in vitro. J Exp Med 1993; 178: 509-519.

19 Childs RA, Feizi T, Yuen CT, Drickamer K, Quesenberry MS. Differential recognition of core and terminal portions of oligosaccharide ligands by carbohydrate-recognition domains of two mannose-binding proteins. J Biol Chem 1990; 265: 20770-20777.

20 Mori K, Kawasaki T, Yamashina I. Subcellular distribution of the mannan-binding protein and its endogenous inhibitors in rat liver. Arch Biochem Biophys 1988; 264 : 647-656.

21 Brock J, Schulze $H$ A, Neels $P$, Fischer A, Bremer $H$, Walzel $H$. Detection of mannose-binding proteins on mouse lymphocytes. Eur J Cell Biol 1991; 54: 90-94.

22 Jiang W, Swiggard WJ, Heufler C, Peng M, Mirza A, Steinman RM, Nussenzweig MC. The receptor DEC-205 expressed by dendritic cells and thymic epithelial cells is involved in antigen processing. Nature 1995; 375: 151-154.

23 Ishizaki J, Hanasaki K, Higashino K, Kishino J, Kikuchi N, Ohara $\mathrm{O}$, Arita $\mathrm{H}$. Molecular cloning of pancreatic group $\mathrm{I}$ phospholipase A2 receptor. J Biol Chem 1994; 8: 58975904.

24 Kuiper J, Otter M, Rijken DC, van Berkel ThJC. Characterization of the interaction in vivo of tissue-type plasminogen activator with liver cells. J Biol Chem 1988; 266: 13931-13935.

25 Sallusto F, Cella M, Danieli C, Lanzavecchia A. Dendritic cells use macropinocytosis and the mannose receptor to concentrate macromolecules in the major histocompatibility complex class II compartment: Downregulation by cytokines and bacterial products. J Exp Med 1995; 182: 389-400.

26 Prigozy TI, Sieling PA, Clemens D, Stewart PL, Behar SM, Porcelli SA, Brenner MB, Modlin RL, Kronenberg M. The mannose receptor delivers lipoglycan antigens to endosomes for presentation to $T$ cells by CD1b molecules. Immunity 1997; 6: 187-197

27 McNally AK, DeFife KM, Anderson JM. Interleukin-4induced macrophage fusion is prevented by inhibitors of mannose receptor activity. Am J Pathol 1996; 149: 975 985.

28 Kluft C. Constitutive synthesis of tissue-type plasminogen activator (t-PA) and plasminogen activator inhibitor type I (PAI-1): Conditions and therapeutic targets. Fibrinolysis 1994; 8 suppl 2: 1-7.

Opdenakker G, Rudd PM, Ponting CP, Dwek RA. 
Concepts and principles of glycobiology. FASEB J 1993; 7:1330-1337.

30 Rijken DC. Plasminogen activators and plasminogen activator inhibitors: biochemical aspects. Baillières's Clinical Haematology 1995; 8: 291-312.

31 Emeis JJ. The control of TPA and PAI-1 secretion from the vessel wall. Vasc Med Rev 1995; 6: 153-166.

32 Brommer AJP, Derkx FHM, Schalekamp MADH, Dooijewaard G. Renal and hepatic handling of endogenous tissue-type plasminogen activator (t-PA) and its inhibitor in man. Thromb Haemostas 1988; 59: 404-411.

33 Cohen AF, Burggraaf $K$, de Boer A, Kluft C. Clearance of plasminogen activators - A major determinant of plasma concentration: therapeutic and diagnostic implications. Ann N Y Acad Sci. 1992; 667: 443-9.

34 Gillis JC, Wagstaff AJ, Goa KL. Alteplase. A reappraisal of its pharmacological properties and therapeutic use in acute myocardial infarction. Drugs 1995; 50: 102-136.

35 Emeis JJ, Bekkers M. Low-dose infusion of tissue-type plasminogen activator (t-PA) prevents arterial thrombosis in a rat thrombosis model: tPA as an antithrombotic agent. Fibrinolysis 1996; 10, Suppl 3: 128. 


\section{CHAPTER 1}

Role of carbohydrate in the binding of tissue-type plasminogen activator to the human mannose receptor.

Femke Noorman, Marrie M. Barrett-Bergshoeff, and Dingeman C. Rijken.

Gaubius Laboratory, TNO Prevention and Health,

Leiden, The Netherlands

Manuscript submitted for publication. 


\section{SUMMARY}

The $175 \mathrm{kDa}$ mannose receptor is one of the receptors that mediates the clearance of tissue-type plasminogen activator ( $t-P A$ ). The affinity of t-PA for the mannose receptor is much higher than the affinity of other high mannose-type oligosaccharide-containing glycoproteins. In order to find an explanation for this high affinity we studied the biochemical interaction of various forms of t-PA with the isolated human mannose receptor in several in vitro binding assays.

t-PA showed a high affinity $(\mathrm{Ki}=0.2 \mathrm{nM})$ for the mannose receptor and the interaction could be fully inhibited by mannan or polyclonal antibodies against the mannose receptor. The interaction was not affected by non-glycosylated t-PA. The high affinity differed slightly between t-PAs synthesized by various cell types and between various glycoforms of t-PA. No statistically significant difference in affinity between t-PA and t-PA complexed to inhibitors was observed. In contrast to intact t-PA, a trypsin digest of t-PA had a low affinity $(\mathrm{Ki}=0.5 \mu \mathrm{M})$ for the mannose receptor. Both intact and trypsin digests of the high mannose-type oligosaccharide-containing glycoproteins ribonuclease B and ovalbumin had a low affinity $(\mathrm{Ki} 0.5-1.5 \mu \mathrm{M})$ for the mannose receptor.

We conclude that neither protein-protein interactions, nor the complex-type oligosaccharides and the fucose residue on t-PA contribute significantly to the high affinity binding of t-PA. We suggest that the conformation of the high mannose-type oligosaccharide on t-PA is influenced by the protein moiety of $t$ $\mathrm{PA}$ in such a way that the oligosaccharide has a high affinity for the mannose receptor.

\section{INTRODUCTION}

The mannose receptor was originally found to be expressed on alveolar macrophages ${ }^{1}$ and the 175 $\mathrm{kDa}$ protein has been isolated from macrophages, ${ }^{2}$ placenta $^{3}$ and liver. ${ }^{4}$ The mannose receptor expressed on macrophages has been implicated as mediating different processes such as endocytosis of glycoproteins, ${ }^{1}$ phagocytosis of organisms having poly-mannose structures on their membrane, ${ }^{5}$ antigen uptake ${ }^{6,7}$ and macrophage fusion into foreign body-type giant cells. ${ }^{8}$ The mannose receptor expressed in the liver has been shown to mediate rapid clearance of high mannose-type oligosaccharide containing glycoproteins from the circulation such as tissue-type plasminogen activator (t-PA). ${ }^{9}$ t-PA is a serine protease that activates fibrinolysis by converting plasminogen into plasmin, which cleaves fibrin into soluble degradation products. ${ }^{10} \mathrm{t}$-PA is successfully used for thrombolytic therapy, for instance after myocardial infarction. ${ }^{11}$ Because of its rapid clearance high doses of t-PA are required to obtain thrombolysis. Thus inhibition of mannose receptor-mediated clearance could be useful in increasing the efficacy of t-PA in thrombolytic therapy. ${ }^{12}$

It has been shown that the binding of t-PA to the mannose receptor is mediated probably by its high mannose-type oligosaccharide. ${ }^{13,14}$ The binding is $\mathrm{pH}$ and $\mathrm{Ca}^{2+}$ dependent and can be inhibited by saccharides such as mannose and mannosylated albumin. ${ }^{4,14}$ The affinity of t-PA for the mannose receptor (Kd 1-4 $\mathrm{nM}^{4,13-15}$ ) is much higher than the affinity of other high mannose-type oligosaccharide containing glycoproteins such as ribonuclease B, B-glucuronidase and ovalbumin (Kd 60-600 nM ${ }^{15-18}$ ). It is not known which structural elements of t-PA are responsible for this higher affinity. Furthermore the clearance of t-PA complexed to plasminogen activator inhibitor type 1 (PAI-1) appears to be slower in human subjects. ${ }^{19,20}$ This might be caused by a lower affinity of t-PA-PAl-1 for the mannose receptor. The affinity of t-PA-proteinase inhibitor complexes for the mannose receptor is, however, not known. 
We initiated this study to determine which structures of t-PA are responsible for the high affinity. We isolated the $175 \mathrm{kDa}$ mannose receptor from human placenta and developed several in vitro binding assays. In these assays we studied the biochemical interactions of various forms of t-PA and t-PAproteinase inhibitor complexes with the mannose receptor. We show that the interaction of t-PA with the mannose receptor varied slightly between the various t-PA preparations, and differed strongly from other high mannose-type oligosaccharide containing glycoproteins, probably by an effect of the protein moiety of t-PA on the conformation of the oligosaccharide.

\title{
MATERIALS AND METHODS
}

\begin{abstract}
Materials
The human mannose receptor was isolated and purified from placental tissue on a mannosylated-albumin-Sepharose column. ${ }^{4,14}$ The column was eluted with $0.2 \mathrm{M} \alpha-\mathrm{D}$-mannose, first in a Triton $\mathrm{X}-100$ free buffer and then in a $1 \%(\mathrm{~V} / \mathrm{V})$ Triton $\mathrm{X}-100$ containing buffer. The isolated protein was demonstrated to be a single $175 \mathrm{kDa}$ protein in SDS-polyacrylamide gel electophoresis. ${ }^{4}$ Polyclonal antibodies were raised against the purified $175 \mathrm{kDa}$ human mannose receptor in a goat and IgG's were isolated from the antiserum by sodium sulphate precipitation. ${ }^{21}$ Control IgG's were isolated similarly from nonimmune goat serum. Melanoma t-PA (mt-PA) was purified from a recombinant human melanoma cell culture. ${ }^{22}$ Recombinant t-PA from $\mathrm{CHO}$ cells (rt-PA) was Actilyse (Boehringer Ingelheim, Ingelheim, Germany). Recombinant non-glycosylated t-PA produced in E. coli (BM 06.021 , molecular mass $59 \mathrm{kDa}^{23}$ ) was a generous gift from Boehringer Mannheim (Mannheim, Germany). A T60A t-PA mutant, lacking the O-linked fucose residue in the growth factor domain, as well as a control t-PA preparation produced similarly were kindly donated by Dr. J. Henkin (Abbott Laboratories, Abbott Park, II., USA). Two-chain rt-PA was prepared by treating single chain rt-PA (Actilyse) with plasmin ${ }^{24}$ and by inhibiting residual plasmin activity with $5 \mu \mathrm{M}$ D-Val-Phe-Lys-chloromethyl ketone (Calbiochem, La Jolla, CA, USA). Type I and type II mt-PA were separated by using lysine-Sepharose chromatography, as described before. ${ }^{25}$ Melanoma t-PA was biotinylated as described earlier. ${ }^{26}$ Mannan (a poly-mannose structure isolated from Saccharomyces cerevisiae) was obtained from Sigma Chemical Co. (St. Louis, MO, USA).
\end{abstract}

\section{Mannose receptor binding assays}

Triton X-100 free purified mannose receptor $(0.15 \mu \mathrm{g} / \mathrm{ml})$ in $20 \mathrm{mM}$ Tris-HCl buffer, $150 \mathrm{mM} \mathrm{NaCl}, 5 \mathrm{mM} \mathrm{CaCl}, \mathrm{pH} 7.4$ (coating buffer) was adsorbed overnight at $4{ }^{\circ} \mathrm{C}$ to the wells of polyvinyl chloride microtitre plates (Flow Laboratories, Irvine, UK). After treating the wells with binding buffer (coating buffer supplemented with $0.5 \%(\mathrm{v} / \mathrm{v})$ Tween 80 and $1 \mathrm{mg} / \mathrm{ml} \mathrm{BSA}$ ) for 0.5 hour at room temperature, the wells were incubated for 2 hours at room temperature with increasing concentrations of biotinylated mt-PA or biotinylated mt-PA-proteinase inhibitor complexes in binding buffer. Bound mt-PA was quantified by incubation of the wells at room temperature for 1 hour with alkaline phosphatase-conjugated streptavidine (Amersham, Buckinghamshire, UK). After washing, the wells were incubated at $25^{\circ} \mathrm{C}$ with the chromogenic substrate p-nitrophenyl phosphate (Sigma Chemical Co., St. Louis, MO, USA). The results were corrected for non-specific binding determined in wells which were "coated" with buffer without mannose receptor. Competitive binding studies were performed by incubating immobilized mannose receptor with mixtures of a non-saturating concentration of biotinylated mt-PA (1-3 nM) and increasing concentrations of inhibitors. When only limited amounts of ligands were available, the binding assay was modified as follows. The immobilized mannose receptor was incubated with $0.14 \mathrm{nM}$ unlabelled $\mathrm{t}-\mathrm{PA}$ preparations. The wells were washed twice with binding buffer and once with $0.1 \mathrm{M} \mathrm{Tris-HCl}$ buffer, $5 \mathrm{mM} \mathrm{CaCl}_{2}, 0.1 \%(\mathrm{~V} / \mathrm{V}) \mathrm{Tween}$ $80, \mathrm{pH} 7.4$. Bound t-PA was eluted with the latter buffer in which $\mathrm{CaCl}_{2}$ was replaced by $10 \mathrm{mM}$ EDTA and then quantified by the $\mathrm{t}-$ PA activity assay of Verheijen et al. ${ }^{27}$

\section{Preparation and quantification of biotinylated $t$-PA inhibitor complexes}

Melanoma t-PA-PAl-1 complex was prepared as described before. ${ }^{28}$ Melanoma t-PA- $\alpha_{2}$-antiplasmin complex was prepared by incubating $1 \mu \mathrm{M} \mathrm{mt}-\mathrm{PA}$ in $50 \mathrm{mM}$ Tris- $\mathrm{HCl}, \mathrm{pH} 7.5$, containing $150 \mathrm{mM} \mathrm{NaCl}, 100 \mathrm{mM}$ 6-aminohexanoic acid (6-AHA) and $0.01 \%$ (V/V) Tween 80 with $2.2 \mu \mathrm{M} \alpha_{2}$-antiplasmin (Biopool, Umeá, Sweden) for $21 \mathrm{hrs}$ at $37^{\circ} \mathrm{C}$. Control mt-PA was incubated similarly without $\alpha_{2}$-antiplasmin. The three preparations were biotinylated ${ }^{26}$ and gel filtered on a Sephacryl S200 HR (Pharmacia, Uppsala, Sweden) column of $100 \times 1 \mathrm{~cm}$ in $50 \mathrm{mM}$ Tris- $\mathrm{HCl}, \mathrm{pH} 7.5$, containing $1.6 \mathrm{M} \mathrm{KSCN}$ and $0.001 \%(\mathrm{v} / \mathrm{v})$ Tween 80 to remove traces of free $\mathrm{mt}-\mathrm{PA}$. The protein preparations were supplemented with BSA (1 mg/ml final concentration), dialyzed against binding buffer of the mannose receptor binding assay, and quantified with an ELISA for t-PA (Biopool, Umeå Sweden) using biotinylated mt-PA as a standard. The ELISA measured t-PA-inhibitor complexes as efficiently as free t-PA. 


\section{Preparation of trypsin digests of glycoproteins}

The glycoproteins rt-PA, ribonuclease B (Sigma, Chemical Co., St Louis, MO, USA) and ovalbumin (Fluka, Buchs, Switzerland) and control buffer, were treated with trypsin (Serva, Heidelberg, Germany) essentially as described for ovalbumin by Glabe et al. ${ }^{29}$ Residual trypsin activity was blocked with $10 \mathrm{KIU} / \mathrm{ml}$ aprotinin (Bayer, Leverkusen, Germany). SDS-polyacrylamide gel electrophoresis on $18 \%(\mathrm{w} / \mathrm{v})$ gels showed that there was no intact glycoprotein left in the solution.

\section{Statistics}

The sigmoidal binding and inhibition curves were analysed using nonlinear regression analysis with the computer program GraphPAD (ISI Software, Philadelphia, PA, USA), yielding the dissociation constant Kd or half maximal inhibitory concentration $\left(\mathrm{IC}_{50}\right)$. The inhibitory constant obtained in the inhibition curve, $\mathrm{Ki}$, was calculated from the $\mathrm{IC}_{50}$, the ligand concentration and the ligand dissociation constant by using the Michaelis-Menten equation $\mathrm{Ki}=\mathrm{IC}_{50} /(1+$ ligand concentration/Kd ligand). "Goodness of fit" was assessed by evaluating the actual distance of the measurements from the fitted line (no weighing). Data are presented as mean \pm standard deviation. Significance of differences was assessed by use of the non-parametric Mann Whitney test: two-tailed $P<0.05$ is defined as significantly different.

\section{RESULTS}

The affinity of melanoma t-PA (mt-PA) for the isolated mannose receptor was determined in two different manners. Increasing concentrations of biotinylated mt-PA were added to the immobilised receptor, which resulted in a typical binding curve (Fig $1 \mathrm{~A})$. Alternatively, a non-saturating concentration of biotinylated mt-PA was added to the receptor in the presence of increasing concentrations of unlabelled mt-PA, which resulted in a typical inhibition curve (Fig 1B). On average the dissociation constant determined in the binding assay (Kd) was $2.4 \pm 0.8 \mathrm{nM}$ (mean $\pm \mathrm{SD}, \mathrm{n}=6$ ) and the inhibitory constant determined in the inhibition assay (Ki) was $0.23 \pm 0.11 \mathrm{nM}(\mathrm{n}=8)$. The lower affinity obtained in the binding assay was probably due to the biotinylation of t-PA.

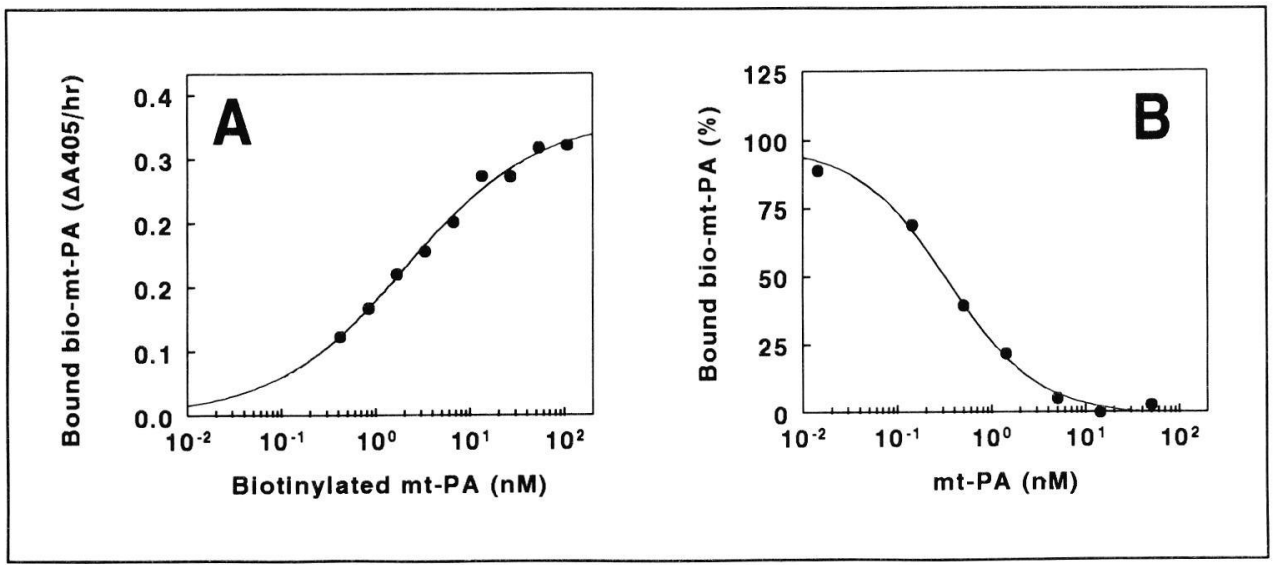

Fig 1 Affinity of mt-PA in the mannose receptor binding assays.

A: typical binding curve of biotinylated mt-PA (bio-mt-PA). Multiwells, coated with isolated human mannose receptor, were incubated with increasing concentrations of bio-mt-PA. After incubation, ligand binding was determined. Binding of bio-mt-PA was corrected for aspecific binding determined in uncoated wells and plotted as $\triangle A 405 / \mathrm{hr}$. B: typical inhibition curve of mt-PA. Multiwells, coated with isolated human mannose receptor, were incubated with a non-saturating concentration of bio-mt-PA in the presence of increasing concentrations unlabelled mt-PA. After incubation, bio-mt-PA binding was determined and corrected for aspecific binding determined in uncoated wells. Binding of bio-mt-PA was expressed as a percentage of the control (without unlabelled mt-PA). 
The specificity of mt-PA binding to the immobilized mannose receptor is shown in Fig 2. Mannan, a known ligand of the mannose receptor inhibited mt-PA binding with a $\mathrm{Ki}$ value of $0.14 \mu \mathrm{g} / \mathrm{ml}$, while nonglycosylated t-PA synthesized by E. coli did not inhibit biotinylated mt-PA binding (Fig 2A). In addition goat polyclonal antibodies raised against the human mannose receptor were able to completely inhibit the binding of mt-PA to the mannose receptor, whereas non-immune immunoglobulines had no effect (Fig $2 B$ ). Since the binding of $t-P A$ to the mannose receptor was fully inhibited by mannan and not inhibited by non-glycosylated t-PA, it is unlikely that protein-protein interactions contribute significantly to the high affinity binding of t-PA. Furthermore the high affinity of t-PA for the mannose receptor in the binding assay did not involve lysine binding sites of t-PA or clustered t-PA molecules, since the lysine analog 6-aminohexanoic acid (6-AHA), which fully dissolves t-PA, did not inhibit the binding of t-PA to the mannose receptor (6-AHA concentration range $0.02-200 \mathrm{mM}$, results not shown).

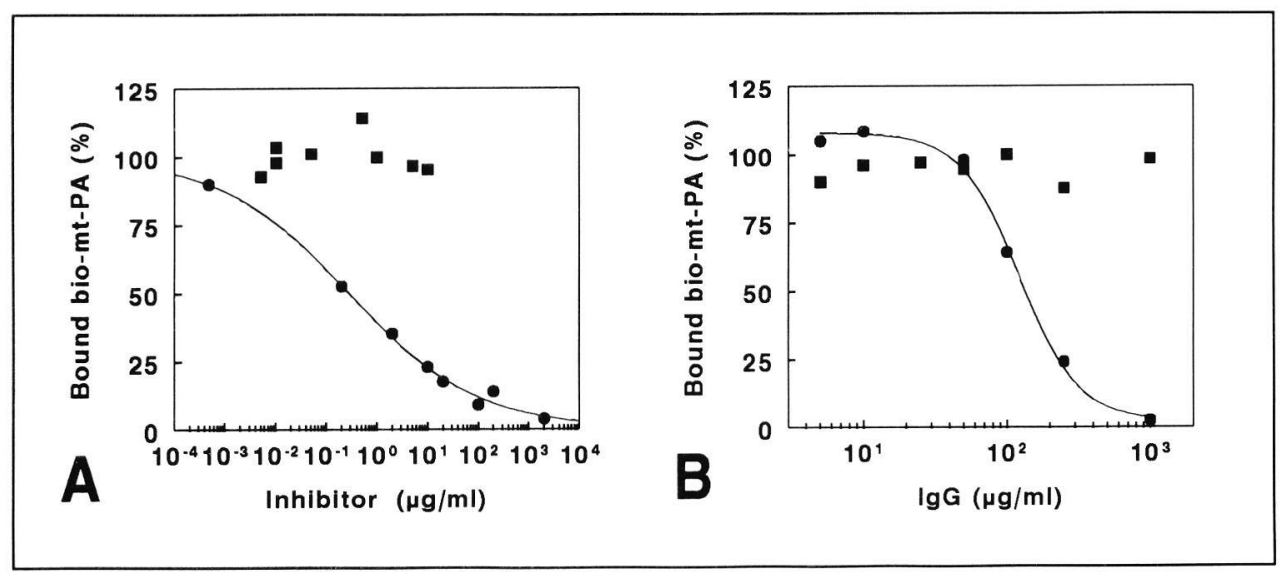

Fig 2 Specificity of mt-PA binding in the mannose receptor binding assay.

The same procedure as described in the legend of Fig 1B was followed, in this case increasing concentrations mannan (-) or nonglycosylated t-PA (घ) were used as inhibitor in Fig 2A. Anti-mannose receptor polyclonal antibodies $(\bullet)$ or non-immune antibodies (घ) were used as inhibitor in Fig 2B.

The above-mentioned experiments were performed with t-PA synthesized by melanoma cells (mt-PA). Recombinant $\mathrm{t}-\mathrm{PA}$ synthesized by $\mathrm{CHO}$ cells (rt-PA) might have a slightly different glycosylation pattern from mt-PA. In the inhibition assay, the affinity of $\mathrm{rt}-\mathrm{PA}$ for the mannose receptor was also high ( $\mathrm{Ki}=$ $0.70 \pm 0.26 n M, n=8)$, but about three times lower than that of mt-PA $\left(K_{i}=0.23 \pm 0.11 n M, n=8\right.$, $\mathrm{P}<0.005)$.

The rt-PA preparation, consisting largely of the single-chain form, was treated with plasmin and converted to the two-chain form. ${ }^{24} \mathrm{Fig} 3$ shows that the two forms of rt-PA had equal affinities for the mannose receptor. These results indicate that the high affinity of t-PA is not dependent on the conformation of the protease domain of t-PA. 
To determine differences in affinity of ligands only available in low amounts a modified binding assay was used. A low concentration (1.3 $\mathrm{nM}$ ) of unlabelled t-PA was incubated with the immobilized mannose receptor. After washing the bound t-PA was eluted from the wells by the use of EDTA and the activity of the eluted t-PA was determined. As shown in Fig 4 similar amounts of type I and type II mt-PA bound to the mannose receptor which indicated that there was also no difference in affinity between type I and type II mt-PA. Both glycoforms of t-PA contain the high mannose-type oligosaccharide on kringle 1 and the complex-type oligosaccharide on the protease domain. Type I t-PA contains a complex-type oligosaccharide on kringle 2, whereas type II t-PA lacks this oligosaccharide. ${ }^{25,30-33}$ These results indicate that the complex-type oligosaccharide on kringle 2 is not involved in the high affinity of t-PA for the mannose receptor.

As expected from the different affinities determined in the above-mentioned experiments less rt-PA than $\mathrm{mt}$-PA type I or type II bound to the mannose receptor (Fig 4). In this modified binding assay, we also tested the affinity of a t-PA mutant, T60A, that lacks the O-linked fucose residue in the growth factor domain. Control t-PA, synthesized by the same cell type as the mutant t-PA, had a similar affinity as itPA since similar percentages bound to the mannose receptor. Slightly less mutant t-PA than control tPA $(2.4 \pm 0.3 \%$ versus $3.6 \pm 0.1 \%$, respectively, $\mathrm{P}<0.05)$ bound to the mannose receptor which indicated that the mutant t-PA had a slightly lower affinity for the mannose receptor. Since the amount of mutant tPA that did bind to the mannose receptor at these low concentrations was still high it is unlikely that the fucose unit strongly contributes to the high affinity of t-PA for the mannose receptor.

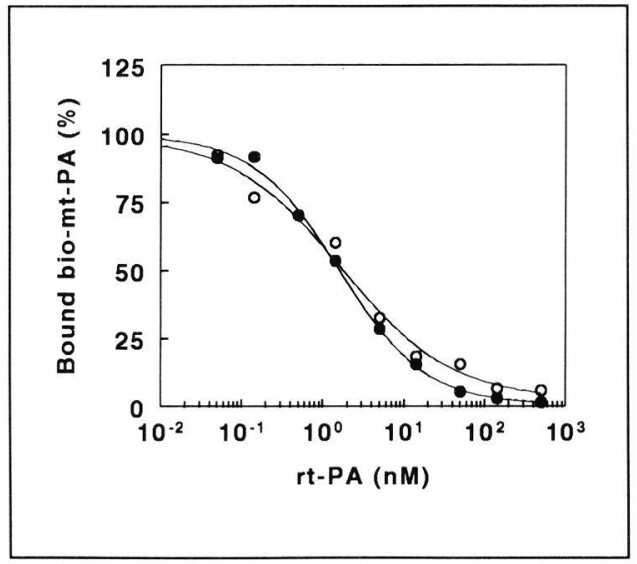

Fig 3 Affinity of single-chain and two-chain rt-PA in the mannose receptor binding assay.

The same procedure as described in the legend of $\mathrm{Fig} 1 \mathrm{~B}$ was followed. In this case increasing concentrations of singlechain $(\bullet)$ or two-chain $(\mathrm{O})$ rt-PA were used as inhibitor.

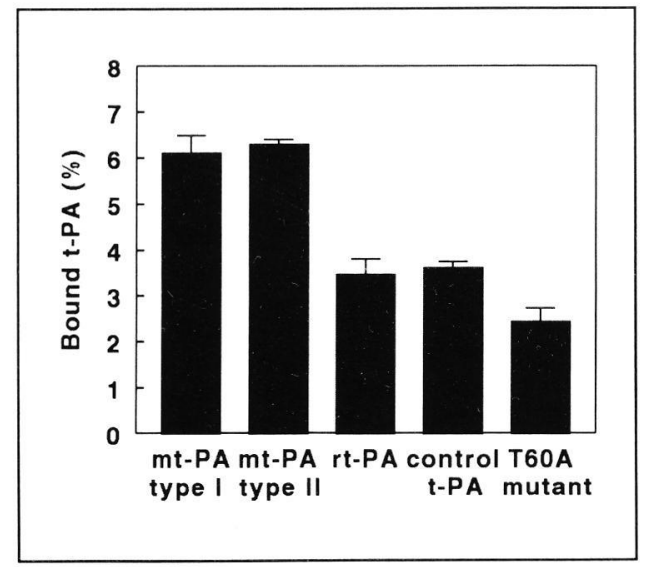

Fig 4 Affinity of type I mt-PA, type II mt-PA, rt-PA, mutant control t-PA and the fucose lacking mutant T60A for the immobilized mannose receptor.

Multiwells, coated with isolated human mannose receptor, were incubated with $0.14 \mathrm{nM}$ unlabeled t-PA variants. After incubation, bound t-PA was eluted using EDTA and t-PA activity was measured. Binding of t-PA was expressed as percentage of the added activity of t-PA ( $n=3$ to 6$)$. 
To determine whether complexation of t-PA to plasma proteinase inhibitors would affect the affinity of t$\mathrm{PA}$ for binding to the mannose receptor, mt-PA and mt-PA-inhibitor complexes were biotinylated and binding curves were generated. As shown in Fig 5, mt-PA complexed to proteinase inhibitors still binds to the mannose receptor with high affinity. There was no statistically significant difference in affinity between mt-PA and mt-PA complexed to $\alpha_{2}$-antiplasmin or PAI-1 (Fig 5, inset).

Fig 5

Affinity of mt-PA-proteinase inhibitor complexes in the mannose receptor binding assay.

Melanoma t-PA and mt-PA complexed to PAl-1 or $\alpha_{2}$-antiplasmin were biotinylated and the affinity of these ligands were determined in the binding assay as described in the legend of Fig $1 \mathrm{~A}$. mt-PA ( $\mathbf{\nabla})$, mt-PA-PAl-1 (•), mt$P A-\alpha_{2}$-antiplasmin (四). The inset shows the non-linear regression curves when the binding of the ligand is expressed as a percentage of the maximal binding of the ligand. These curves represent a correction for the differences in biotinylation of the ligands.

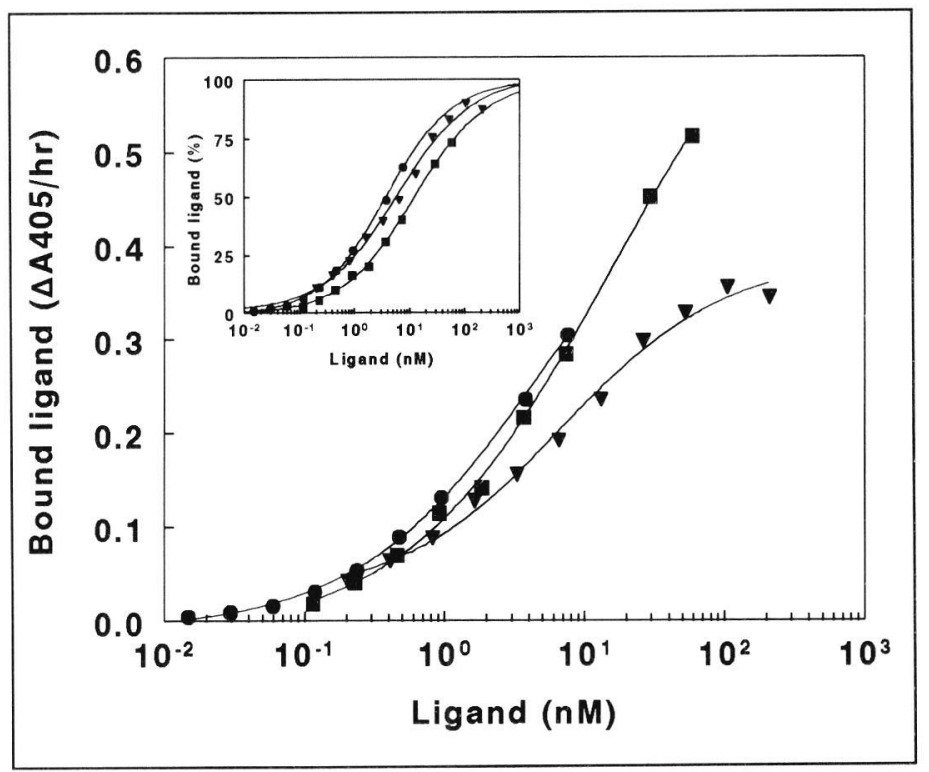

Using the competitive inhibition assay, we compared the affinity of t-PA to those of two other high mannose-type oligosaccharide containing ligands, ribonuclease $B$ and ovalbumin. As shown in Fig $6 \mathrm{~A}$, rt-PA had a much higher affinity $(\mathrm{Ki}=1.0 \mathrm{nM}$ ) than ribonuclease $\mathrm{B}$ and ovalbumin $(\mathrm{Ki}=505$ and $549 \mathrm{nM}$, respectively) for binding to the isolated mannose receptor. To determine whether the protein structures of these ligands would be responsible for the observed differences in binding affinity, trypsin digests were made of above-mentioned ligands. The trypsin digest of rt-PA had an approximately 500 -fold lower affinity for the mannose receptor than intact rt-PA (Fig $6 \mathrm{~B}$ ), whereas the trypsin digests of ovalbumin and ribonuclease $B$ only had a 2-3 times lower affinity for the mannose receptor than the intact glycoproteins. After trypsin digestion, the affinity of the degraded glycoproteins for the mannose receptor was similar for all three glycoproteins. Thus the protein structure of t-PA appeared to be involved in the high affinity of the high mannose-type oligosaccharide of $t-P A$ for binding to the mannose receptor. 

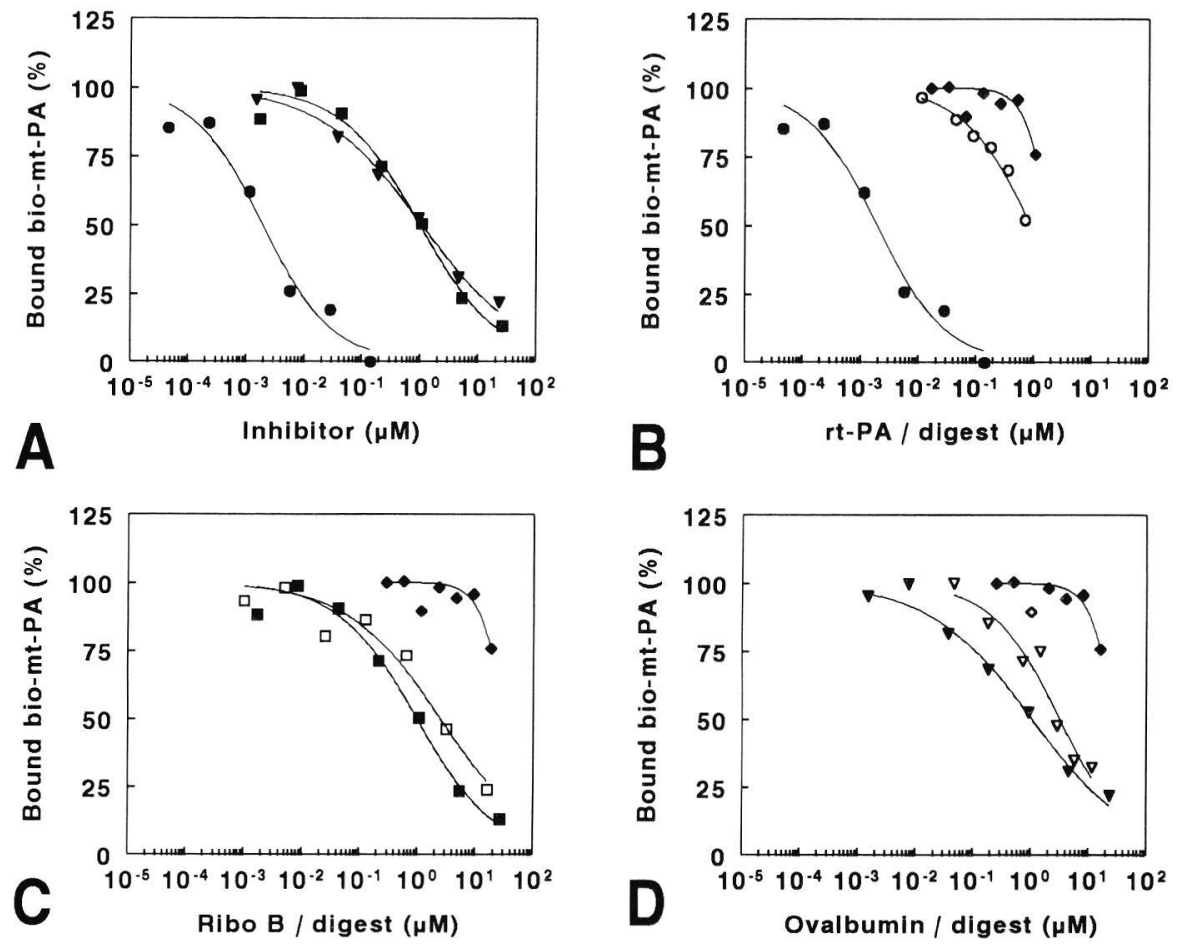

Fig 6 Affinity of t-PA, ribonuclease B, ovalbumin and their trypsin digests for the immobilized mannose receptor.

The same procedure as described in the legend of Fig $1 \mathrm{~B}$ was followed. In this case increasing concentrations of intact glycoproteins or trypsin digests were used. A: inhibition curves of rt-PA $(-)$, ribonuclease B $(\boldsymbol{\varpi})$, and ovalbumin $(\nabla)$. The inhibition curves of the intact ligands were compared to the inhibition curves of their trypsin digest (open symbols) and of control buffer (trypsin treated buffer without glycoprotein, $\$$ ) in B-D. The 'concentration' of the control buffer represents the amount of trypsin present in the trypsin digest shown in the figure. B: intact t-PA, t-PA digest and control buffer, $\mathrm{C}$ : intact ribonuclease B, ribonuclease B digest and control buffer, $D$ : intact ovalbumin, ovalbumin digest and control buffer.

\section{DISCUSSION}

Previous studies in our laboratory showed that t-PA probably binds with its high mannose-type oligosaccharide in a $\mathrm{Ca}^{2+}$ dependent way to the mannose receptor. The binding of t-PA can be inhibited by mannose, fucose, $\mathrm{N}$-acetylglucosamine and synthetic poly-mannose ligands. ${ }^{4,14,15}$ The affinity of $\mathrm{t}$-PA for the mannose receptor is much higher than the affinity of other high mannose-type oligosaccharide containing glycoproteins. ${ }^{15-18}$ This study was initiated to determine which structures of t-PA are responsible for this higher affinity.

We isolated the human mannose receptor from placenta and developed several in vitro assays, in which the mannose receptor was immobilized. By the use of binding and competitive inhibition assays it was shown that the t-PA affinity of binding to the isolated mannose receptor had a high affinity $(0.23-2.4$ $n M)$. Similar high affinities were reported for the binding of t-PA to the mannose receptor isolated from bovine alveolar macrophages ${ }^{14}$ and the mannose receptor expressed by rat liver endothelial cells. ${ }^{13}$ 
The specificity of the binding of t-PA to the mannose receptor immobilized on mictrotitre plates was demonstrated clearly as mannan and polyclonal anti-mannose receptor antibodies were able to inhibit tPA binding completely. We investigated if oligosaccharides other than the high mannose-type oligosaccharide on kringle 1 were involved in the high affinity binding of t-PA. The carbohydrate structures on mt-PA and rt-PA have been determined in various studies. ${ }^{30-34}$ The complex-type oligosaccharides differed in the linkage of the terminal sialic acid on the galactose ( $\alpha 2-6$ linked in mt-PA and $\alpha 2-3$ linked in rt-PA), ${ }^{32}$ the presence of a biantennary complex-type oligosaccharide with a terminal $\mathrm{N}$-acetylgalactosamine (GaINAc) structure in mt-PA, ${ }^{34}$ and the presence of terminal intersecting $\mathrm{N}$ acetylglucosamine (GICNAc) residues in rt-PA. ${ }^{32}$ It has been shown that terminal intersecting GlcNAc residues can influence the orientation of the oligosaccharide on the protein. ${ }^{35}$ Alternatively, t-PA binding to the mannose receptor might directly involve this GlcNAc. However it has also been shown that peptides containing complex-type oligosaccharides with or without terminal intersecting GlcNAc residues do not bind to the mannose receptor. ${ }^{17}$ There proved to be a slight but significant difference in affinity of mt-PA and rt-PA for binding to the isolated mannose receptor. Though the affinity of rt-PA was lower than the affinity of mt-PA, the affinity of rt-PA was still very high. This indicates that the terminal intersecting GICNAc residues of the complex-type oligosaccharides do not contribute to the high affinity of $t$-PA for the mannose receptor.

There was no difference in the affinity of type I and type II t-PA for the mannose receptor. This shows that the complex-type oligosaccharide on kringle 2 is not involved in the binding of t-PA to the mannose receptor. Substitution of the threonine that contains an O-linked fucose residue with a (non glycosylated) alanine in the growth factor domain, ${ }^{36}$ slightly reduced the affinity of t-PA for the mannose receptor. Since the mutant $t-P A$ did considerably bind to the mannose receptor at low concentrations it is however unlikely that the fucose unit is important for the high affinity of t-PA for the mannose receptor.

Complex formation of t-PA with its natural inhibitors PAl-1 or $\alpha_{2}$-antiplasmin did not significantly affect the affinity for binding to the mannose receptor. Interaction of t-PA-PAI-1 with the mannose receptor explains the uptake of the complex by liver endothelial cells in vivo. ${ }^{28}$ The results indicate that the protease domain involved in the complex formation with these inhibitors does not contribute to the binding of $t-P A$ to the mannose receptor. It has been suggested that t-PA-PAl-1 complexes are cleared more slowly than free t-PA in vivo in man. ${ }^{19.20}$ Since the other receptor that mediates t-PA clearance, the low density lipoprotein receptor-related protein (LRP), ${ }^{12}$ appeared to have a higher affinity for t-PA-PAl-1 than for t-PA, ${ }^{37}$ the apparently lower clearance rate of t-PA-PAl-1 in man cannot be explained by reduced affinity of the complex for the mannose receptor or the LRP.

The mannose receptor contains 8 carbohydrate recognition domains (CRD). ${ }^{38}$ It has been shown that the mannose receptor has a high affinity for mannan $(\mathrm{Ki}=100 \mathrm{nM}) .{ }^{39}$ Since mannan has a much lower affinity ( $\mathrm{Ki}$ in the $\mu \mathrm{M}$ to $\mathrm{mM}$ range) for mutant mannose receptors lacking one or more of these CRDs it was concluded that CRD 4,5 and 7 are essential for the high affinity binding ( $\mathrm{Ki}$ in the $\mathrm{nM}$ range) of mannan. ${ }^{39,40}$ Various studies indicated that the distance between the terminal mannose residues of polymannosides or oligosaccharides determines the affinity of ligand for the mannose receptor. ${ }^{15,41,42}$ 
The affinities of ribonuclease B and ovalbumin (both high mannose-type oligosaccharide-containing glycoproteins) for the mannose receptor were found to be similar to the affinities reported for ribonuclease $B$, ovalbumin and B-glucuronidase. ${ }^{15-18}$ We showed that all t-PA variants studied had a much higher affinity for the mannose receptor than ribonuclease B and ovalbumin. Since the CRD 4,5 and 7 are essential for the high affinity to the receptor, we suggest that t-PA binds simultaneously to the mannose receptor CRD 4,5 and 7, which results in high affinity binding, whereas ovalbumin or ribonuclease $\mathrm{B}$ may only bind to two out of three CRDs which results in a much lower affinity. However, besides some microheterogenity, the structures of the high mannose-type oligosaccharides of t-PA, ${ }^{30-34}$ ovalbumin ${ }^{43}$ and ribonuclease $B^{44}$ are essentially the same, and we showed that the other oligosaccharides present on t-PA did not seem to be involved in the high affinity binding of t-PA.

It has been shown that the protein core of complement $\mathrm{C} 3$ and ribonuclease $\mathrm{B}$ restricts the binding of the lectins conglutinin and mannose binding protein to the oligosaccharide probably by influencing the conformation or the accessibility of the oligosaccharide. ${ }^{45}$ Thus we hypothesized that the protein part of ribonuclease $B$ and ovalbumin restricts the binding of the high mannose-type oligosaccharide to the mannose receptor. However, the trypsin digests of ribonuclease B and ovalbumin had a 2-3 times lower affinity than the intact glycoproteins. This showed that the lower affinity of ovalbumin and ribonuclease $B$ did not originate from restriction by the protein core.

Trypsin digests of t-PA, ribonuclease B and ovalbumin all had a similar low affinity (Ki 0.5-1.5 $\mu \mathrm{M})$. This showed that the high affinity of intact t-PA for the mannose receptor was not caused by a different type of high mannose-type oligosaccharide. Since non-glycosylated t-PA nor 6-AHA could inhibit the binding of t-PA to the mannose receptor, this interaction is not likely to be mediated by protein-protein interactions. The trypsin digests of t-PA had a 500 times lower affinity than intact t-PA. These findings indicate that the protein structure is involved in the high affinity of the high-mannose-type oligosaccharide of t-PA for binding to the mannose receptor.

It is possible that the protein structure of t-PA influences the conformation or accessibility of its high mannose-type oligosaccharide. For IgM and ribonuclease $B$ it has been shown that the motion of the oligosaccharides is not influenced by the protein structures. ${ }^{46}$ However, for the glycoprotein IgG it has been shown that the protein core can interact with the terminal saccharides of its oligosaccharide in such a way that the motion of the oligosaccharide is restricted. ${ }^{47}$ More rigid oligosaccharides have been suggested to have a higher affinity for lectins. ${ }^{48}$ Since trypsin digests of t-PA had a much lower affinity for the mannose receptor, we suggest that the protein core of t-PA interacts with the high mannose-type oligosaccharide in such a way that the oligosaccharide on the intact protein can interact with a higher affinity with the mannose receptor than the free oligosaccharide and the high mannose-type oligosaccharide on ribonuclease B or ovalbumin.

\section{ACKNOWLEDGEMENT}

We thank Dr. P. J. Dörr (Department of Obstretics and Gynaecology, Westeinde Hospital, The Hague, The Netherlands) for providing placenta tissue. This study was financially supported by the Netherlands Heart Foundation grant no. 90.294. 


\section{REFERENCES}

1 Stahl, P. D., Somsel Rodman, J., Miller, M. J. \& Schlesinger, P. H. (1978) Evidence for receptor-mediated binding of glycoproteins, glycoconjugates, and lysosomal glycosidases by alveolar macrophages, Proc. Nat. Acad. Sci. USA. 75, 1399-1403.

2 Haltiwanger, R. S. \& Hill, R. L. (1986) The ligand binding specificity and tissue localization of a rat alveolar macrophage lectin, J. Biol. Chem. 261, 15696-15702.

3 Lennartz, M. R., Cole, F. S., Shepherd, V. L., Wileman, T. E. \& Stahl, P. D. (1987) Isolation and characterization of a mannose-specific endocytosis receptor from human placenta. J. Biol. Chem. 262, 9942-9944.

4 Otter, M., Zockova, P., Kuiper, J., van Berkel, Th. J. C., Barrett-Bergshoeff, M. M. \& Rijken, D. C. (1992) Isolation and characterization of the mannose receptor from human liver potentially involved in the plasma clearance of tissuetype plasminogen activator. Hepatology 16, 54-59.

5 Ofec, I., Goldhar, J., Keisari, Y. \& Sharon, N. (1995) Nonopsonic phagocytosis of microorganisms. Annu. Rev. Microbiol. 49, 239-276.

6 Sallusto, F., Cella, M., Danieli, C. \& Lanzavecchia, A. (1995) Dendritic cells use macropinocytosis and the mannose receptor to concentrate macromolecules in the major histocompatibility complex class II compartment: Downregulation by cytokines and bacterial products. J. Exp. Med. 182, 389-400.

7 Prigozy, T. I., Sieling, P. A., Clemens, D., Stewart, P. L., Behar, S. M., Porcelli, S. A., Brenner, M. B., Modlin, R. L. \& Kronenberg, M. (1997) The mannose receptor delivers lipoglycan antigens to endosomes for presentation to $T$ cells by CD1b molecules. Immunity 6, 187-197.

8 McNally, A. K., DeFife, K. M. \& Anderson, J. M. (1996) Interleukin-4-induced macrophage fusion is prevented by inhibitors of mannose receptor activity. Am. J. Pathol. 149, 975-985.

9 Kuiper, J., Otter, M., Rijken, D. C., van Berkel, Th. J. C. (1988) Characterization of the interaction in vivo of tissuetype plasminogen activator with liver cells. J. Biol. Chem. 266, 13931-13935.

10 Emeis, J. J., Verheijen, J. H., Ronday, H. K., de Maat, M. P. M. \& Brakman, P. (1997) Progress in clinical fibrinolysis. Fibrinolysis \& Proteolysis 11, 67-84.

11 Collen, D. Fibrin-selective thrombolytic therapy for acute myocardial infarction. (1996) Circulation 93, 857-865.

$1 \varepsilon$ Biessen, E. A. L., van Teijlingen, M., Vietsch, H., BarrettBergshoeff, M. M., Bijsterbosch, M. K., Rijken, D. C., van Berkel, Th. J. C. \& Kuiper, J. (1997) Antagonists of the mannose receptor and the LDL-receptor-related protein dramatically delay the clearance of tissue-type plasminogen activator. Circulation 95, 46-52.

13 Otter, M., Kuiper, J., Rijken, D. C. \& van Berkel, Th. J. C. (1992) Characterization of the interaction both in vitro and in vivo of tissue-type plasminogen activator (t-PA) with rat liver cells. Effect of monoclonal antibodies to t-PA.
Biochem. J. 284, 545-550

14 Otter, M., Barrett-Bergshoeff, M. M. \& Rijken, D. C. (1991) Binding of tissue-type plasminogen activator by the mannose receptor. J. Biol. Chem. 266, 13931-13935.

15 Biessen, E. A. L., Noorman, F., van Teijlingen, M. E., Kuiper, J., Barrett-Bergshoeff, M. M., Bijsterbosch, M. K., Rijken, D. C. \& van Berkel, Th. J. C. (1996) Lysine-based cluster mannosides that inhibit ligand binding to the human mannose receptor at nanomolar concentration. J. Biol. Chem. 271, 28024-28030. (Chapter 6 of this thesis)

16 Shepherd, V. L., Campbell, E. J., Senior, R. M. \& Stahl, P. D. (1982) Characterization of the mannose/fucose receptor on human mononuclear phagocytes. J. Reticuloendoth. Soc. 32, 423-431.

17 Maynard, Y. \& Baenziger, J. U. (1981) Oligosaccharide specific endocytosis by isolated rat hepatic reticuloendothelial cells. J. Biol. Chem. 256, 8063-8068.

18 Magnussen, S. \& Berg, T. (1989) Extremely rapid endocytosis mediated by the mannose receptor of sinusoidal endothelial rat liver cells. Biochem. J. 257, 651656.

19 Juhan-Vague, I., Chandler, W. L., Aillaud, M. F., Alessi, M. C., Vague, P. \& Henderson, P. (1996) Humans clear active t-PA faster than tPA.PAl-1 complex. Fibrinolysis 10, Suppl 3, 102.

20 Chandler, W. L., Levy, W. C. \& Stratton, J. R. (1995) The circulatory regulation of IPA and UPA secretion, clearance, and inhibition during exercise and during the infusion of isoproterol and phenylepinephrine. Circulation 92, 29842994.

21 Kekwick, R. A. (1940) The serum proteins in multiple myelomatosis. Biochem. J. 34, 1248-1257.

22 Browne, M. J., Dodd, I., Carey, J. E., Chapman, C. G. \& Robinson, J. H. (1985) Increased yield of human tissuetype plasminogen activator obtained by means of recombinant DNA technology. Thromb. Haemostas. 54, 422-424.

23 Stockinger, H., Kubbies, M., Rudolph, R., Stern, A., Kohnert, U. \& Fischer, S. (1992) Binding of recombinant variants of human tissue-type plasminogen activator ( $t-P A)$ to human umbilical vein endothelial cells. Thrombosis Research 67, 589-599.

24 Rijken, D. C., Groeneveld, E. \& Barrett-Bergshoeff, M. M. (1994) In vitro stability of a tissue-type plasminogen activator mutant, BM 06.022, in human plasma. Thromb. Haemostas. 72, 906-911.

25 Rijken, D. C., Emeis, J. J. \& Gerwig, G. J. (1985) On the composition and function of the carbohydrate moiety of tissue-type plasminogen activator from human melanoma cells. Thromb. Haemostas. 54, 788-791

26 Barrett-Bergshoeff, M. M., Noorman, F., Bos, R. \& Rijken, D. C. (1997) Monoclonal antibodies against the human mannose receptor that inhibit the binding of tissue-type plasminogen activator. Thromb. Haemostas. 77, 718-724. 
(Chapter 3 of this thesis)

27 Verheijen, J. H., Mullaart, E., Chang, G. T. G., Kluft, C. \& Wijngaards, G. (1982) A simple, sensitive spectrophotometric assay for extrinsic (tissue-type) plasminogen activator applicable to measurements in plasma. Thromb. Haemostas. 48, 266-269.

28 Kuiper, J., Otter, M., Voorschuur, A. H., van Zonneveld, A. J., Rijken, D. C. \& van Berkel, Th. J. C. (1995) Characterization of the interaction of a complex of tissuetype plasminogen activator and plasminogen activator inhibitor type 1 with rat liver cells. Thromb. Haemostas. 74 , 1298-12304.

29 Glabe, C. G., Hanover, J. A. \& Lennarz, W. J. (1980) Glycosylation of ovalbumin nascent chains. The spatial relationship between translation and glycosylation. J. Biol. Chem. 255, 9236-9242.

30 Pohl, G., Kenne, L., Nilsson, B. \& Einarsson, M. (1987) Isolation and characterization of three different carbohydrate chains from melanoma tissue plasminogen activator. Eur. J. Biochem. 170, 69-75.

31 Parekh, R. B., Dwek, R. A., Thomas, J. R., Opdenakker G. \& Rademacher, T. W. (1989) Cell-type-specific and site-specific N-glycosylation of type I and type II human tissue plasminogen activator. Biochemistry 28, 7644-7662.

32 Spellman, M. W., Basa, L. J., Leonard, C. K., Chakel, J. A \& O'Connor, J. V. (1989) Carbohydrate structures of human tissue plasminogen activator expressed in Chinese hamster ovary cells. J. Biol. Chem. 264, 14100-14111.

33 Carr, S. A., Roberts, G. D., Jurewicz, A. \& Frederick, B. (1988) Structural fingerprinting of Asn-linked carbohydrates from specific attachment sites in glycoproteins by mass spectrometry: application to tissue plasminogen activator. Biochimie 70, 1445-1454.

34 Chan, A. L., Morris, H. R., Panico, M., Etienne, A. T., Rogers, M. E., Gaffney, P., Creighton-Kempsford, L. \& Dell, A. (1991) A novel sialyated $\mathrm{N}$-acetylgalactosaminecontaining oligosaccharide is the major complex-type structure present in Bowes melanoma tissue plasminogen activator. Glycobiology 1, 173-185.

35 Savvidou, G., Klein, M., Grey, A. A., Dorrington, K. J. \& Carver, J. P. (1984) Possible role for peptideoligosaccharide interactions in differential oligosaccharide processing at Asparagine-107 of the light chain and Asparagine-297 of the heavy chain in a monoclonal $\lg _{1}$. Biochemistry 23, 3736-3740.

36 Harris, R. J., Leonard, C. K., Guzetta, A. W. \& Spellman, M. W. (1991) Tissue plasminogen activator has an Olinked fucose attached to threonine-61 in the epidermal growth factor domain. Biochemistry 30, 2311-2314.

37 Nykjaer, A., Kjoller, L., Cohen, R. L., Lawrence, D. A., Garni-Wagner, B. A., Todd III, R. F., van Zonneveld, A. J.,
Gliemann, J. \& Andreassen, P. A. (1994) Regions involved in binding of urokinase-type-1 inhibitor complex and prourokinase to the endocytotic $\alpha_{2}$-macroglobulin receptor/low density lipoprotein receptor-related protein. J. Biol. Chem. 269, 25668-25676.

38 Taylor, M. E., Conary, J. T., Lennartz, M. R., Stahl, P. D. \& Drickamer, K. (1990) Primary structure of the mannose receptor contains multiple motifs resembling carbohydraterecognition domains. J. Biol. Chem. 265, 2156-12162.

39 Taylor, M. E., Bezouska, K. \& Drickamer, K. (1992) Contribution to ligand binding by multiple carbohydraterecognition domains in the macrophage mannose receptor. J. Biol. Chem. 267, 51719-1726.

40 Taylor, M. E. \& Drickamer, K. (1993) Structural requirements for high affinity binding of complex ligands by the mannose receptor. J. Biol. Chem. 268, 399-404.

41 Onsumi, Y., Hoppe, C. A., Ogawa, T. \& Lee, Y. C. (1988) Enhancement of macromolecular ligand binding by rabbit alveolar macrophages by mannose oligosaccharides and related compounds. Arch. Biochem. Biophys. 260, 241 249.

42 Robbins, J. C., Lam, M. H., Tripp, C. S., Bugianesi, R. L., Ponpipom, M. M. \& Shen, T. Y. (1981) Synthetic glycopeptide substrates for receptor-mediated endocytosis by macrophages. Proc. Nat. Acad. Sci. 78, 7294-7298.

43 Conchie, J. \& Strachan, I. (1978) The carbohydrate units of ovalbumin: complete structures of three glycopeptides. Carbohydrate Res. 63, 193-213.

44 Liang, C. J., Yamashita, K. \& Kobata, A. (1980) Structural study of the carbohydrate moiety of bovine pancreatic ribonuclease B. J. Biochem. 88, 51-58.

45 Solis, D., Feizi, T., Yuen, C. T., Lawson, A. M., Harrison, R. A. \& Loveless, R. W. (1994) Differential recognition by conglutinin and mannan-binding protein of $\mathrm{N}$-glycans presented on neoglycolipids and glycoproteins with special reference to complement glycoprotein $\mathrm{C} 3$ and ribonuclease B. J. Biol. Chem. 269, 11555-11562.

46 Edge, C. J., Joao, H. C., Woods, R. J. \& Wormal, M. R. (1993) The conformational effects of $N$-linked glycosylation. Biochem. Soc. Trans. 21, 453-455.

47 Malhotra, R., Wormald, M. R., Rudd, P. M., Fischer, P. B., Dwek, R. A. \& Sim, R. B. (1995) Glycosylation changes of IgG associated with rheumatoid arthritis can activate complement via the mannose-binding protein. Nature Med. 1, 237-243.

48 Debray, H., Decout, D., Strecker, G., Spik, G. \& Montreuil, J. (1981) Specificity of twelve lectins towards oligosaccharides and glycopeptides related to $\mathrm{N}$ glycosylproteins. Eur. J. Biochem. 117, 41-55. 


\section{CHAPTER 2}

Degradation of tissue-type plasminogen activator by human monocyte-derived macrophages is mediated by the mannose receptor and by the low density lipoprotein receptor-related protein.

Femke Noorman, Ellen A.M. Braat and Dingeman C. Rijken

Gaubius Laboratory, TNO-Prevention and Health, Leiden, The Netherlands.

Reproduced from

Blood, 1995, 86:3421-3427 


\section{SUMMARY}

The balance of tissue-type plasminogen activator ( $t$-PA) production and degradation determines its concentration in blood and tissues. Disturbance of this balance may result in either increased or decreased proteolysis. In the present study we identified the receptor systems involved in the degradation of t-PA by human monocytes/macrophages in culture.

Monocytes were cultured and became macrophages within 2 days. At $4{ }^{\circ} \mathrm{C}$, ${ }^{125} \mathrm{l}$-t-PA bound to macrophages with high (apparent dissociation constant $(\mathrm{kd}), 1$ to $5 \mathrm{nmol} / \mathrm{L}$ ) and low affinity $(\mathrm{kd}>350$ $\mathrm{nmol} / \mathrm{L}$ ). At $37^{\circ} \mathrm{C}$, the cells internalized and degraded t-PA via the high affinity binding sites, which were partially inhibited by mannan. The low affinity binding sites were 6-aminohexanoic acid-inhibitable and not involved in t-PA degradation. Degradation of t-PA was upregulated during differentiation of monocytes to macrophages. Dexamethasone further upregulated the mannan-inhibitable t-PA degradation. Lipopolysaccharide downregulated both mannan-inhibitable and non-mannan-inhibitable tPA degradation. Non-mannan-inhibitable degradation was completely blocked by recombinant 39-kD receptor-associated protein (RAP, inhibitor of lipoprotein receptor-related protein (LRP)), whereas mannan-inhibitable degradation was blocked by the addition of a monoclonal antibody against the mannose receptor. No differences between the degradation of t-PA and functionally inactivated t-PA were observed.

We conclude that human monocyte-derived macrophages are able to bind, internalize, and degrade tPA. Degradation of t-PA does not require complex formation with plasminogen activator inhibitors. The macrophages use two independently regulated receptors, namely the mannose receptor and LRP, for the uptake and degradation of t-PA.

\section{INTRODUCTION.}

Tissue-type plasminogen activator (t-PA) is a serine protease that converts plasminogen into plasmin, which in turn converts fibrin into fibrin degradation products, and is synthesized and secreted mainly by vascular endothelial cells. Recombinant t-PA is at present used as a thrombolytic drug, for instance, after a myocardial infarction. This glycoprotein $(70 \mathrm{kD})$ contains one high mannose-type oligosaccharide and one or two complex-type oligosaccharides. ${ }^{1}$ It is rapidly cleared from the plasma probably by the mannose receptor on liver endothelial cells and the $\alpha_{2}$-macroglobulin receptor/ low density lipoprotein receptor-related protein (LRP) on hepatocytes. ${ }^{2-4}$

Macrophages arise from stem cell precursors in the bone marrow, circulate as monocytes in blood, and migrate into tissues to assume their mature state. The functional state of the macrophage (see reviews

${ }^{5-7}$ ) is dependent on the tissue of maturation and on the (pathologic) conditions in the environment. Many stimuli induce macrophages to secrete plasminogen activators to stimulate plasmin-mediated proteolysis. The plasminogen activators may be of the urokinase-type (u-PA) ${ }^{8,9}$ or tissue-type (t-PA). ${ }^{10,11}$

Monocytes are recruited to the site of inflammation, and within 3 days macrophages represent the major cell type at this site. ${ }^{12}$ When these macrophages are eliminated (using anti-macrophage serum), clearance of fibrin, dead cells and other debris necessary for repair is delayed. ${ }^{13}$ For this clearance it is essential that the macrophage has several ways to regulate its endocytotic activities and the proteolytic activities in its environment. 
This study was designed to investigate whether human monocyte-derived macrophages are able to bind, internalize, and degrade t-PA. Because macrophages express the mannose receptor ${ }^{14}$ and may recognize t-PA through its high mannose-type oligosaccharide, we specifically studied the potential role of this receptor in t-PA metabolism. We used human buffy coats to isolate monocytes, cultured them to become macrophages, and studied their interaction with ${ }^{125}$ l-labeled t-PA. Specific inhibitors and regulators were used to identify the macrophage receptors interacting with t-PA.

\title{
MATERIALS AND METHODS.
}

\begin{abstract}
Materials
Human $\mathrm{AB}^{+}$serum, and 1-day-old human buffy coats or thrombocyte-poor pooled buffy coats from healthy donor blood, were obtained from the Red Cross Blood Bank (The Hague and Leiden, The Netherlands). Ficoll-Paque (Pharmacia LKB, Biotechnology $A B$, Uppsala, Sweden) or Lymphoprep (Nycomed Pharma AS, Oslo, Norway) having a density of $1.077 \mathrm{~g} / \mathrm{mL}$ was used for density gradient centrifugation. Heparin (Leo Pharmaceutical Products, Ballerup, Denmark), bovine serum albumin (BSA; Boseral, Organon Teknika, Boxtel, The Netherlands) or BSA fraction V (Sigma Chemical Co, St. Louis, MO), cell culture medium M199 (Flow Laboratories, Irvine, UK), penicillin/streptomycin (Pen/strep; Boehringer Mannheim, Mannheim, Germany), and sterile buffers were used to isolate and culture the cells. They were cultured in plastic culture plates (Costar Co, Cambridge, MA). Fluorescence-labeled monoclonal antibodies against the human monocyte/macrophage CD14 antigen (CD14-FITC) were obtained from Becton Dickinson Immunocytometry Systems (San Jose, CA). Dexamethasone and lipopolysaccharide extracted from Escherichia coli 0111:B4 were purchased from Sigma Chemical Co. Recombinant melanoma cell-derived t-PA (85\% single chain) was prepared at our laboratory, ${ }^{15.16}$ and recombinant t-PA (Actilyse) was obtained from Boehringer Ingelheim (Ingelheim, Germany). PPACK (D-Phe-Pro-Argchloromethylketone) was from Calbiochem (La Jolla, CA). S-2288 (D-lle-Pro-Arg-pNA) was purchased from Chromogenix, Mölndal, Sweden. 6-Aminohexanoic acid (6-AHA; Merck Schuchardt, München, Germany), mannose-BSA (mannose $26 \mathrm{~mol} / \mathrm{mol}$ BSA) and mannan extracted from Saccharomyces cerevisiae, prepared by the cetavlon method (Sigma Chemical Co), ovalbumin (Serva, Heidelberg, Germany), mouse monoclonal antibodies against the human placenta mannose receptor (prepared by Barrett-Bergshoeff et al. at our laboratory), and GST-RAP (prepared at our laboratory by Dr J.H. Verheijen using the Salmonella japonicum glutathioneS-transferase (GST)-RAP expression plasmid, ${ }^{17}$ provided by Dr J. Herz, University of Texas, Southwestern Medical Center, Dallas, TX) were used for inhibition studies.
\end{abstract}

\section{Cell isolation and cultivation}

Buffy coat $(100 \mathrm{~mL})$ was diluted with $180 \mathrm{~mL}$ phosphate buffered saline $\left(4.5 \mathrm{mmol} / \mathrm{L} \mathrm{KCL}, 228 \mathrm{mmol} / \mathrm{L} \mathrm{NaCl}, 13.5 \mathrm{mmol}^{2} \mathrm{~L} \quad \mathrm{Na}_{2} \mathrm{HPO}_{4}\right.$, $2.5 \mathrm{mmol} / \mathrm{L} \mathrm{KH}_{2} \mathrm{PO}_{4}, \mathrm{pH} 7.4$ ) containing $10 \mathrm{U} / \mathrm{mL}$ heparin. Portions of $35-\mathrm{mL}$ suspension were underlayered with $14 \mathrm{~mL}$ Ficoll-Paque or Lymphoprep. After 30 minutes' centrifugation at $800 \mathrm{~g}$, the interface was collected and washed $(250 \mathrm{~g}, 10$ minutes) twice with phosphate-buffered saline (PBS: $2.7 \mathrm{mmol} / \mathrm{L} \mathrm{KCl}, 137 \mathrm{mmol} / \mathrm{L} \mathrm{NaCl}, 8.1 \mathrm{mmol} / \mathrm{L} \quad \mathrm{Na}_{2} \mathrm{HPO}_{4}, 1.46 \mathrm{mmol} / \mathrm{L} \quad \mathrm{KH}_{2} \mathrm{PO}_{4}$ ), $\mathrm{pH} \quad 7.4$, containing $0.9 \mathrm{mmol} / \mathrm{L} \mathrm{CaCl}_{2}, 0.5 \mathrm{mmol} / \mathrm{L} \mathrm{MgCl}$ and $0.1 \% \mathrm{BSA}$. Routinely 1 to $2 \times 10^{\circ}$ cells were obtained. Cells were suspended in $\mathrm{M} 199$, and $5 \times 10^{6}$ cells per well were seeded in 12-well plates. Cells were cultured at $37^{\circ} \mathrm{C}$ in $5 \% \mathrm{CO}_{2} / 95 \%$ air. After 1 hour, nonadherent cells were removed when the medium was replaced by culture medium (M199 containing $1 \%$ glutamine, $50 \mathrm{U} / \mathrm{mL}$ penicillin, $50 \mathrm{ug} / \mathrm{mL}$ streptomycin, $10 \%$ human $\mathrm{AB}^{+}$serum). Every 2 or 3 days, the medium was refreshed.

For some experiments the cell suspension obtained after gradient centrifugation was further purified using countercurrent flow centrifugation (elutriation) essentially as described by Weiner and Shah. ${ }^{18}$ The elutriator (J2-21 centrifuge, JE-6 rotor, standard elutriation chamber; Beckman Instruments Inc, Palo Alto, CA) was first washed with $70 \%$ ethanol, then with $0.9 \% \mathrm{NaCl}$, and finally with cold $\left(4^{\circ} \mathrm{C}\right.$ ) PBS containing $0.1 \%$ BSA (elutriation buffer, EB). Cells washed twice with EB were injected into the elutriation chamber at $2,500 \mathrm{rpm}, 10^{\circ} \mathrm{C}$, flow rate $2 \mathrm{~mL} / \mathrm{min}$. The flow was increased ( $1 \mathrm{~mL} / \mathrm{min}$ per 15 seconds) to $14 \mathrm{~mL} / \mathrm{min}$. Erythrocytes, thrombocytes, and lymphocytes were collected in $400 \mathrm{~mL}$ eluate. The flow was increased again, and monocytes were collected in 100 $\mathrm{mL}$ - at $17 \mathrm{~mL} / \mathrm{min}, 100 \mathrm{~mL}$ at $19 \mathrm{~mL} / \mathrm{min}$ and $100 \mathrm{~mL}$ at $21 \mathrm{~mL} / \mathrm{min}$. The fractions were combined, and cells were washed with PBS and resuspended in M199. Routinely, 1 to $2 \times 10^{8}$ cells were obtained. Cells were plated at a concentration of $1 \times 10^{6}$ cells per well in 24-well plates, and after 1 hour the medium was replaced by culture medium. Every 2 or 3 days, the medium was refreshed.

To analyze the purity of the cell suspensions obtained, a sample of $1 \times 10^{6}$ cells was washed with EB and incubated with CD14-FITC (1:20) for 30 minutes at $4^{\circ} \mathrm{C}$. Cells were washed once and resuspended in EB, and forward scatter (cell size), side scatter (cell density), and FITC fluorescence were measured using a FACScan flow cytometer (Becton Dickinson Immunocytometry Systems). Data were analysed using FACScan software. The cut-off point for positive $\left(C D 14^{+}\right)$/negative cells was determined with reference to the fluorescence of cells not incubated with CD14-FITC. 
The extra elutriation step eliminated plateiet contamination of the monocytes in culture and did not affect morphological changes during culture. in the experiments described below, no differences were observed between cultured density-gradient-centrifugationpurified or elutriation-purified cells.

\begin{abstract}
Labeling of t-PA
Melanoma and recombinant t-PA were labeled with ${ }^{125} \mathrm{I}$ using the iodogen method. ${ }^{19}$ Polyethylene vessels of $1.5 \mathrm{~mL}$ were coated with $10 \mu \mathrm{g}$ iodogen. $\mathrm{Ni}, 10 \mu \mathrm{g} \mathrm{t}-\mathrm{PA}$ in $50 \mathrm{mmol} / \mathrm{L}$ Tris- $\mathrm{HCl}, 0.25 \mathrm{~mol} / \mathrm{L}$ 6-AHA, $1 \mathrm{~mol} / \mathrm{L} \mathrm{NaCl}, \mathrm{pH} 8$, was incubated with $0.5 \mathrm{mCi} \mathrm{Na}^{125}$ for $10 \mathrm{~min}$ at roor. temperature in the vessel. The mixture was transferred to another vessel containing an equal volume of $4 \mathrm{mg} / \mathrm{mL}$ $\mathrm{KI}$ to avoid non-specific binding of ${ }^{125} \mathrm{I}$ to t-PA. Labeled t-PA was separated from free ${ }^{125}$ I using a 10-mL Sephadex G25 Coarse column (eluant $50 \mathrm{mmol} / \mathrm{L}$ Tris- $\mathrm{HCl}, 0.01 \%$ Tween $80,1 \mathrm{mg} / \mathrm{mL} \mathrm{BSA}, \mathrm{pH}$ 8). Labeling resulted in approximately $600 \mathrm{cpm} / \mathrm{fmol}$, with $80 \%$ recovery of t-PA activity. When indicated, ${ }^{125} \mathrm{I}-\mathrm{t}-\mathrm{PA}$ was incubated with $2 \mu \mathrm{mol} / \mathrm{L}$ PPACK for 2 hours at room temperature and overnight at $4{ }^{\circ} \mathrm{C}$. The radiolabeled PPACK-t-PA was completely inactivated when tested in the colorimetric activity assay using S2288. In the studies described below, no differences were observed between labeled or unlabeled melanoma or recombinant $t-P A$
\end{abstract}

\title{
Binding of ${ }^{125}$ l-t-PA
}

To remove non-adherent cells and serum components, cells (12-well plates) were washed once with PBS, $1 \% \mathrm{BSA}$, pH 4, to remove possible receptor ligands and twice with PBS, $1 \% \mathrm{BSA}, \mathrm{pH} 7.4,4^{\circ} \mathrm{C}$. ${ }^{125}$-t-PA with or without inhibitors in $500 \mu \mathrm{L}$ M199, $1 \%$ BSA, $0.01 \%$ Tween 80 was added. After incubation at $4^{\circ} \mathrm{C}$, the medium was removed and the cells were washed with PBS, $\mathrm{pH} 7.4$, containing $0.9 \mathrm{mmol} / \mathrm{L} \mathrm{CaCl}$ and $0.5 \mathrm{mmol} / \mathrm{L} \mathrm{MgCl}$ with (twice) and without (twice) $0.1 \% \mathrm{BSA}$, and lysed with $1 \%$ Triton $\mathrm{X}-100$ for 15 minutes at room temperature. Radioactivity of the lysates was determined. Binding of ${ }^{125} \mathrm{I}$-t-PA was corrected for plastic binding in empty parallel wells ( $10 \%$ to $20 \%$ of total binding).

\section{Association and degradation of ${ }^{125}$ l-t-PA}

Cells were washed (three times with PBS, $1 \% \mathrm{BSA}, \mathrm{pH} 7.4,4^{\circ} \mathrm{C}$ ) and incubated with ${ }^{125} \mathrm{I}$-t-PA, with or without inhibitors in $500 \mu \mathrm{L}$ (12-well plates) or $300 \mathrm{LL}$ (24-well plates) $\mathrm{M} 199,1 \% \mathrm{BSA}, 0.01 \%$ Tween 80 , at $37^{\circ} \mathrm{C}$ in $5 \% \mathrm{CO}_{2} / 95 \%$ air. After incubation cell media were collected, and trichloroacetic acid (TCA) was added (final concentration $10 \%$ wt/vol). Non-degraded ${ }^{125}$-t-PA was precipitated by centrifugation ( 10 minutes at $15,000 \mathrm{~g}$ ). To eliminate the possibility that the cells might deiodinate rather than degrade ${ }^{125} \mathrm{I}-\mathrm{t}-\mathrm{PA}$, free ${ }^{125} \mathrm{I}$ was extracted. To the $500 \mu \mathrm{L}$ TCA-soluble supernatant obtained, $5 \mu \mathrm{L} 40 \%$ (wt/vol) $\mathrm{KI}$ and $25 \mu \mathrm{L} \mathrm{H}_{2} \mathrm{O}_{2} 30 \%$ (vol/vol) were added. After 5 minutes, the free iodine was extracted with $800 \mu \mathrm{L}$ chloroform. The radioactivity of the remaining ${ }^{125}$-tyrosine (and possibly ${ }^{125} \mathrm{I}$-peptides) in the upper layer $\left(5\right.$ minutes at $15,000 \mathrm{~g}$ ) representing degraded ${ }^{125} \mathrm{I}$-t-PA, was determined. Radioactivity associated with the cells was determined as described for binding at $4^{\circ} \mathrm{C}$. Association and degradation were corrected for radioactivity determined in empty parallel wells (less than $5 \%$ ).

\section{Statistics}

Inhibition of the binding or degradation of ${ }^{125}$-t-t-PA by unlabeled $t-P A$ or other compounds will lead to a decreased value for ${ }^{125} \mathrm{I}-\mathrm{t}-\mathrm{PA}$ binding or degradation expressed as a percentage of control. No inhibition would result in a constant value of $100 \%$ (in spite of the fact that the specific radioactivity is diluted when unlabeled t-PA is tested as inhibitor). At nonsaturating concentrations of labeled compound, a concentration range of inhibitor was added, and the binding or degradation was measured. These inhibition curves were analysed using nonlinear regression analysis with the computer program GraphPAD (ISI Software, Philadelphia, PA), yielding total number of binding sites, apparent dissociation constants (kd), half-maximal inhibitory concentration (IC50), and Hill-slopes. "Goodness of fit" was assessed using actual distances. Using the computer program SOLO 4.0 (BMDP Statistical Software, Los Angeles, $C A$ ), the statistical significance of differences was determined with the nonparametric Mann-Whitney test. Two-tailed $P$ $<.05 \%$ is defined as significantly different. Data are presented as mean \pm standard error of the mean (SEM).

\section{RESULTS.}

Monocytes were isolated from human buffy coats and cultured to study the interaction of monocytes/macrophages with t-PA. Using density gradient centrifugation, a cell suspension was obtained that contained about $20 \% \mathrm{CD} 4^{+}$monocytes. We further purified the suspension by elutriation, and obtained a suspension with approximately $85 \%$ CD14 $4^{+}$monocytes. Cells able to adhere to plastic within 1 hour were cultured. The round flat monocytes turned within 2 days into cells with a more contracted appearance and extending pseudopods (macrophages). After the sixth day the first multinuclear giant cells (fused macrophages) started to appear. These results indicated that the majority of the monocytes was differentiated into macrophages between 2 and 7 days of culture. These cells were used for this study. 
To determine the presence of t-PA binding sites on the cell membrane of macrophages, the interaction with ${ }^{125} \mathrm{I}$-t-PA was studied at $4^{\circ} \mathrm{C}$. ${ }^{125} \mathrm{I}-\mathrm{t}-\mathrm{PA}$ appeared to be bound by the macrophages. To determine whether ${ }^{125}$ I-t-PA was bound specifically by the cells, inhibition of ${ }^{125}$-t-PA binding by unlabeled t-PA was studied (Fig 1). Binding of ${ }^{125} \mathrm{l}$-t-PA to macrophages was partially t-PA-inhibitable (high affinity binding), and partially non-inhibitable by $350 \mathrm{nmol} / \mathrm{L} \mathrm{t}-\mathrm{PA}$ (low affinity binding). Binding of t-PA to lysine residues is blocked by $6-\mathrm{AHA}$. Binding of t-PA to the cells was partially inhibited by 6 -AHA. Maximal inhibition was obtained at concentrations higher than $10 \mathrm{mmol} / \mathrm{L} 6-\mathrm{AHA}$ (not shown). In the presence of $20 \mathrm{mmol} / \mathrm{L} 6$ AHA, only high affinity binding of t-PA was found (Fig 1). Nonlinear regression analysis of the t-PA inhibition curves resulted in an apparent $\mathrm{kd}$ of $1 \mathrm{nmol} / \mathrm{L}$ in the absence of, and an apparent $\mathrm{kd}$ of 5 $\mathrm{nmol} / \mathrm{L}$ in the presence of, 6-AHA. This indicated that 6-AHA did not significantly influence the interaction of t-PA with high affinity binding sites. We found $14 \times 10^{3}$ to $18 \times 10^{8}$ high affinity binding sites per cell. The Hill-slopes calculated for both curves were, respectively, -0.6 and -0.8 , suggesting that more than one high affinity receptor was involved in the binding of t-PA.

We observed the interaction of macrophages and t-PA at $37^{\circ} \mathrm{C}$ to study t-PA catabolism by metabolically active cells. During incubation of $5 \mathrm{nmol} / \mathrm{L}{ }^{125} \mathrm{I}-\mathrm{t}-\mathrm{PA}$ with macrophages, association (bound and internalized ${ }^{125} \mathrm{I}-\mathrm{t}-\mathrm{PA}$ ) reached a maximal level within 2 hours. Association was accompanied by release of ${ }^{125}$-tyrosine into the medium (degradation) from 15 minutes onward. After this lag phase the cells degraded approximately 200 molecules per cell per minute for at least 4 hours. ${ }^{125}$-t-PA degradation was inhibited by chloroquine $(100 \mu \mathrm{mol} / \mathrm{L})$ or $\mathrm{NH}_{4} \mathrm{Cl}(10 \mathrm{mmol} / \mathrm{L})$ for $75 \%$ (not shown), indicating that the degradation was dependent on acidification of the lysosomal compartment.

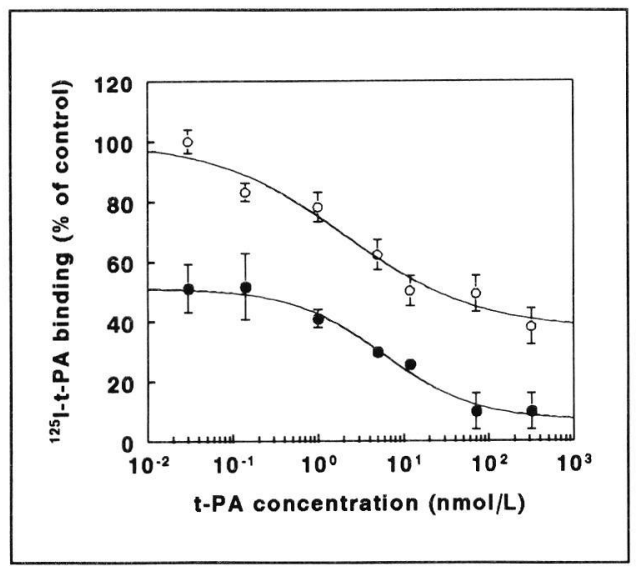

Fig 1 t-PA binding to macrophages.

Monocytes/macrophages (4- to 6-day-old) were incubated for 2 hours at $4^{\circ} \mathrm{C}$ with $1 \mathrm{nmol} / \mathrm{L}^{125} \mathrm{I}-\mathrm{t}-\mathrm{PA}$ with $(\bullet)$ or without $(0)$ $20 \mathrm{mmol} / \mathrm{L}$ 6-AHA, and different concentrations of unlabeled tPA. Data $(n=6)$ were expressed as a percentage of control and were fitted as a sigmoid curve using nonlinear regression analysis.

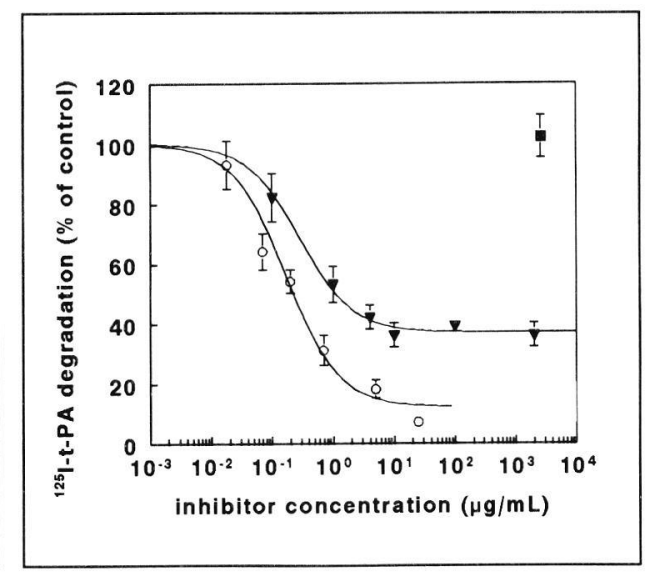

Fig 2 t-PA degradation by macrophages.

Monocytes/macrophages (3-day-old) were incubated with 1 $\mathrm{nmol} / \mathrm{L}{ }^{125} \mathrm{I}-\mathrm{t}-\mathrm{PA}$ for 3 hours at $37{ }^{\circ} \mathrm{C}$ and with different concentrations of unlabeled t-PA $(\mathrm{O})$, different concentrations of mannan ( $\nabla)$, or $2.61 \mathrm{mg} / \mathrm{mL}$ (20 mmoll ) 6-AHA ( $\mathbf{\square})$, and degradation was determined. Data $(n=9)$ were expressed as a percentage of control and were fitted as a sigmoid curve using nonlinear regression analysis. 
As shown in Fig 2, degradation of ${ }^{125} \mathrm{I}$-t-PA was fully inhibited by unlabeled t-PA (IC50, $0.2 \mu \mathrm{g} / \mathrm{mL}$ or 3 $\mathrm{nmol} / \mathrm{L}$ ). The IC50 value showed that binding to high affinity binding sites is followed by uptake and degradation. Degradation was not inhibited by $2.61 \mathrm{mg} / \mathrm{mL}$ (20 mmol/L) 6-AHA (Fig 2), indicating that low affinity binding of t-PA does not result in uptake and degradation. Mannan, a mannose receptor ligand, partially (maximally 60\%) inhibited t-PA degradation (IC50 = $0.3 \mu \mathrm{g} / \mathrm{mL}$; Fig 2). Other ligands for the mannose receptor, like ovalbumin and mannose-BSA, inhibited degradation to the same extent (not shown).

How is t-PA binding, internalization, and degradation influenced by the differentiation of monocytes to macrophages in vitro? Monocytes were cultured for 7 days, and each day, ${ }^{125}$-t-PA binding, association, and degradation in the absence or presence of mannan was determined. One-day-cultured monocytes did bind, internalize, and degrade t-PA (Fig 3). Binding and association gradually increased with time in culture. After a culture period of 2 days (macrophages), the degradation strongly increased, and a maximum was reached at day 3 . After this day, the degradation gradually diminished (details not shown). On average (days 2 to 7), t-PA binding, association, and degradation increased, respectively, three, eight, and seven times after differentiation from monocyte to macrophage (Fig 3). Binding, association, and degradation were not mannan-inhibitable at day 1 , but they became partially mannaninhibitable at days 2 to 7 . Non-mannan-inhibitable degradation was, on average, four times upregulated after day 1 (Fig 3).

\section{Fig 3}

t-PA binding, association, and degradation by human monocytes/ macrophages.

Monocytes were cultured for 7 days. On each day, binding ( 2 hours, $4^{\circ} \mathrm{C}$ ), association, and degradation (5 hours, $37^{\circ} \mathrm{C}$ ) of $1 \mathrm{nmol} / \mathrm{L} \quad{ }^{125} /$-t-PA were determined in the absence (घ) or presence of $1 \mathrm{mg} / \mathrm{mL}$ mannan ( $\square$ ). Data are shown for monocytes cultured for 1 day (mo; $n=6$ ), or monocytes cultured for 2 to 7 days (macrophages, mph; $n=36$ ).

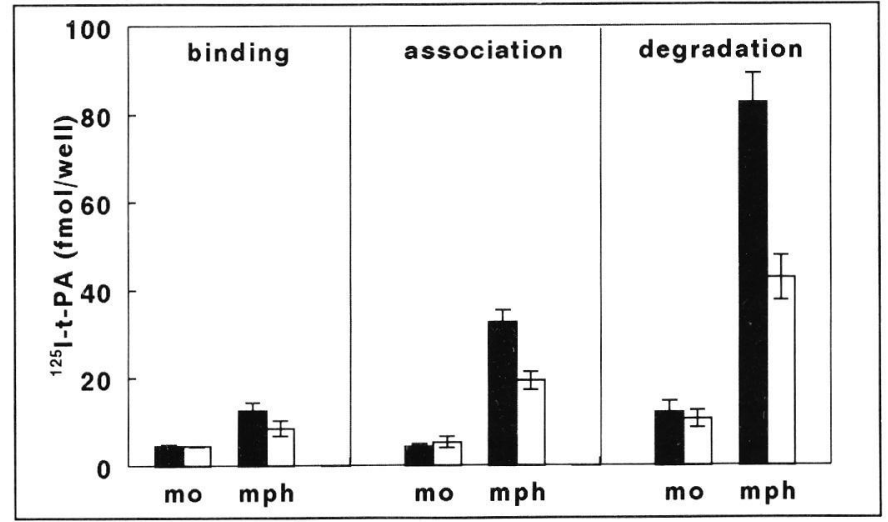

How does suppression or activation of macrophages influence the ability to degrade t-PA? We studied ${ }^{125}$ I-t-PA degradation by monocytes cultured for 7 days in the presence of the immunosuppressor dexamethasone (DEX) or the activator lipopolysaccharide (LPS). DEX did not have a clear effect on cell morphology. Monocytes cultured with LPS obtained a different morphology from the first day onward. Cells had more and longer pseudopods than nonstimulated cells, while having a smaller centre. Both LPS and DEX had a strong effect on the ${ }^{125}$ I-t-PA degradation by macrophages (Fig 4): total ${ }^{125}$ I-t-PA degradation was upregulated two times by DEX and four times downregulated by LPS. Mannaninhibitable degradation was 2.5 times upregulated by DEX, while non-mannan-inhibitable degradation was not affected. Mannan-inhibitable degradation was five times downregulated by LPS, while nonmannan-inhibitable degradation was, on average, three times downregulated (two times downregulated at days 2 to 3 and five times downregulated at days 4 to 7 ; details not shown). We concluded that monocyte-derived macrophages express different t-PA receptors which are independently regulated. 
Fig 4

Effect of dexamethasone and LPS on macrophage receptor-mediated t-PA degradation.

Monocytes were cultured for 7 days without (control) or with $0.1 \mu \mathrm{g} / \mathrm{mL}$ DEX or $0.1 \mu \mathrm{g} / \mathrm{mL}$ LPS. Average degradation ( 5 hours, $37^{\circ} \mathrm{C}$ ) of $1 \mathrm{nmol} / \mathrm{L}^{125} \mathrm{I}$-t-PA by 2- to 7-day-old monocytes/macrophages $(n=36)$ in the absence $(\square)$ or presence $(\square)$ of $1 \mathrm{mg} / \mathrm{mL}$ mannan is shown.

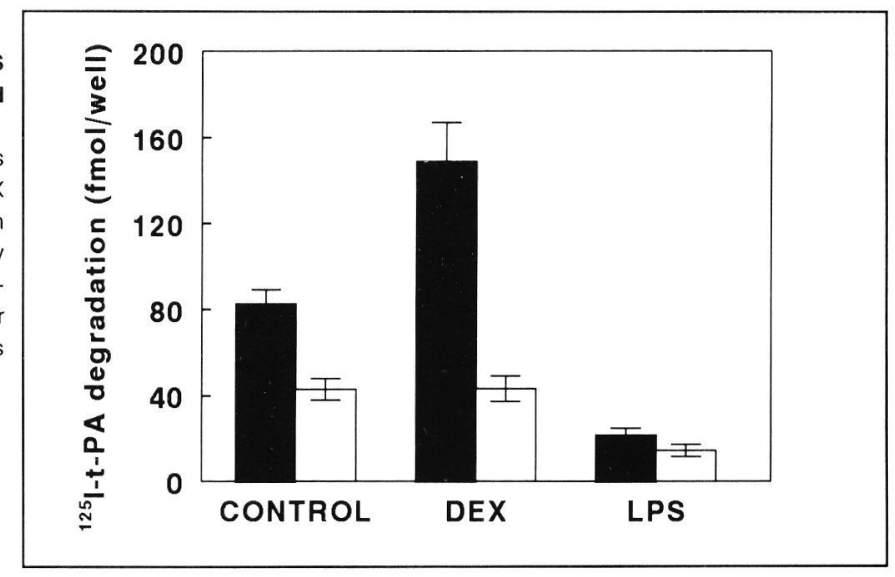

Recent studies by $\mathrm{Bu}$ et al. ${ }^{20,21}$ suggested that t-PA can bind to LRP, which is also expressed on monocytes/macrophages. ${ }^{22}$ GST-RAP, a known inhibitor of the interaction of t-PA, t-PA-plasminogen activator inhibitor-1 (t-PA-PAI-1) and other ligands with the LRP, was used to study the possible involvement of LRP. As shown in Fig 5, GST-RAP significantly inhibited degradation of t-PA, and degradation was abolished when $1 \mathrm{mg} / \mathrm{mL}$ mannan was coincubated. Half-maximal inhibition of the degradation by GST-RAP was at $5 \mathrm{nmol} / \mathrm{L}$ with and $3 \mathrm{nmol} / \mathrm{L}$ without mannan.

Similar results were obtained with 3-day-old macrophages cultured without and with DEX or with LPS. GST-RAP (100 nmol/L) inhibited, respectively, $62 \pm 2 \%, 23 \pm 6 \%$ and $96 \pm 2 \%$ of $\mathrm{t}-\mathrm{PA}(1 \mathrm{nmol} / \mathrm{L})$ degradation $(n=4)$. Coincubation of GST-RAP $(100 \mathrm{nmol} / \mathrm{L})$ with mannan $(1 \mathrm{mg} / \mathrm{mL})$ inhibited $\mathrm{t}-\mathrm{PA}$ degradation for $95 \pm 1 \%$ in all cases. We concluded that the non-mannan-inhibitable degradation of $t$ PA by untreated as well as by suppressed or activated macrophages was mediated by the LRP.

Table 1 shows the effect on the t-PA degradation by macrophages of a monoclonal antibody (MoAb) raised against purified human mannose receptor. $A$ control MoAb of the same isotype did not affect t-PA degradation at $10 \mu \mathrm{g} / \mathrm{mL}$ (not shown). Degradation was inhibited by $10 \mu \mathrm{g} / \mathrm{mL}$ anti-mannose receptor MoAb. This did not significantly differ from inhibition with mannan. Coincubation of this MoAb with mannan did not have any additional effect. Coincubation of $10 \mu \mathrm{g} / \mathrm{mL}$ anti-mannose receptor MoAb with $25 \mathrm{nmol} / \mathrm{L}$ GST-RAP reduced degradation to $13 \%$. We concluded that the mannan-inhibitable t-PA degradation by macrophages is mediated by the mannose receptor.

No differences were observed in this model between t-PA and PPACK-t-PA (Fig 6), indicating that uptake and degradation of $\mathrm{t}-\mathrm{PA}$ did not require complex formation with plasminogen activator inhibitors. 


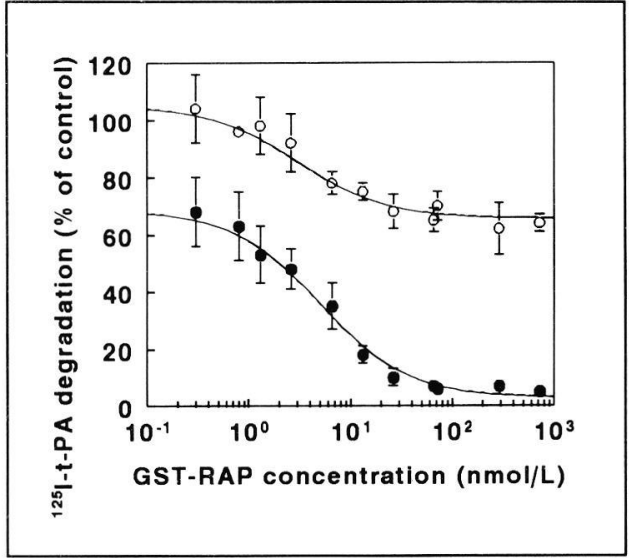

Fig 5 LRP-mediated t-PA degradation by human macrophages.

Monocytes/macrophages (3-day-old) were incubated with 1 $\mathrm{nmol} / \mathrm{L}{ }^{125} \mathrm{I}-\mathrm{t}-\mathrm{PA}$ for 3 hours at $37^{\circ} \mathrm{C}$. Inhibition of t-PA degradation with different concentrations of GST-RAP without $(O)$ or with $(\bullet) 1 \mathrm{mg} / \mathrm{mL}$ mannan was determined. Inhibition by GST-RAP was statistically significant $(P<.05)$ from 6 $\mathrm{nmol} / \mathrm{L}$ onward. Data $(\mathrm{n}=4)$ were expressed as a percentage of control and were fitted as a sigmoid curve using nonlinear regression analysis.

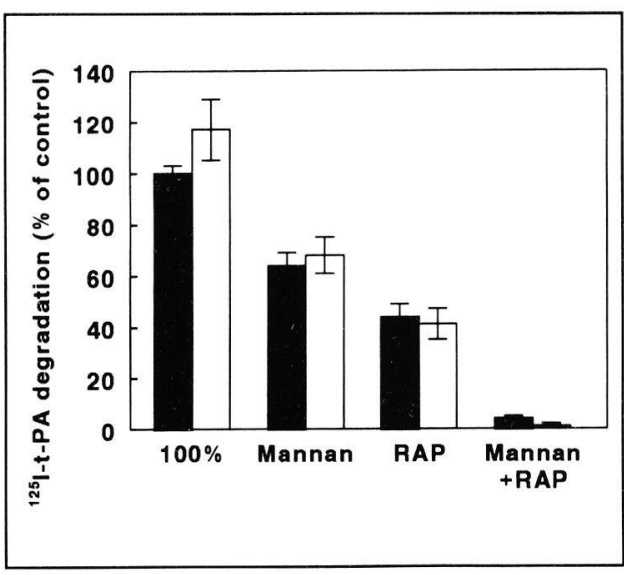

Fig 6 Degradation of inactivated t-PA by human macrophages.

Monocytes/macrophages (2- to 6-day-old) were incubated with $1 \mathrm{nmol} / \mathrm{L}$ ligand for 4 hours at $37^{\circ} \mathrm{C}$. Average degradation of ${ }^{125} \mathrm{I}$-t-PA (घ) or PPACK - ${ }^{125} \mathrm{I}$-t-PA ( $\square$ ) by the cells without and with $1 \mathrm{mg} / \mathrm{mL}$ mannan, $100 \mathrm{nmol} / \mathrm{GST}$-RAP, or both was determined. Data $(n=20)$ were expressed as a percentage of the ${ }^{125}$ I-t-PA control.

Tabel 1 MoAb inhibition of ${ }^{125} \mathrm{I}-\mathrm{t}-\mathrm{PA}(1 \mathrm{nmol} / \mathrm{L})$ degradation by three-day-old macrophages.

\begin{tabular}{|c|c|c|c|}
\hline Inhibitor & Concentration & Control & $\begin{array}{c}\text { + Anti-mannose receptor MoAb } \\
10 \mu \mathrm{g} / \mathrm{mL}\end{array}$ \\
\hline None & & $100 \pm 3$ & $56 \pm 6^{\star}$ \\
\hline Mannan & $1 \mathrm{mg} / \mathrm{mL}$ & $49 \pm 3$ & $45 \pm 4$ \\
\hline GST-RAP & $25 \mathrm{nmol} / \mathrm{L}$ & $60 \pm 4$ & $13 \pm 1^{\star}$ \\
\hline
\end{tabular}

The values represent the residual degradation indicated by the mean percentage of control without inhibitor \pm SEM $(n=6)$.

* Significantly different from control. 


\section{DISCUSSION}

Monocytes differentiated into macrophages within 2 days after plastic attachment. The morphological changes we observed are similar to those observed by others. ${ }^{23-25}$ We showed that t-PA bound to high and low affinity binding sites on monocyte-derived macrophages. The high affinity binding sites were ascribed to the mannose receptor and LRP. The low affinity binding sites ( $\mathrm{kd}>350 \mathrm{nmol} / \mathrm{L}$ ) were 6 AHA-inhibitable.

Low affinity binding of t-PA has been observed for isolated lipoprotein(a), ${ }^{26}$ apo(a) free low-densitylipoprotein, ${ }^{26}$ fibrinogen, ${ }^{26}$ activated platelets, ${ }^{27}$ melanoma cells, ${ }^{28}$ monocytes,${ }^{29}$ monocytoid cell lines, ${ }^{29}$ endothelial cells, ${ }^{29}$ and isolated human liver membrane. ${ }^{30}$ Low affinity, 6-AHA-inhibitable binding sites may play an important role for cell bound plasminogen activator activity. ${ }^{31-33}$ Our study showed that these binding sites were not essential for the uptake and degradation of t-PA by macrophages, because 6-AHA did not inhibit t-PA degradation.

The apparent kd of t-PA for the high affinity receptors we found on macrophages was 1 to $5 \mathrm{nmol} / \mathrm{L}$ (14 $\times 10^{3}$ to $18 \times 10^{3}$ binding sites per cell). These high affinity binding sites mediated t-PA degradation (the half-maximal inhibition of degradation of ${ }^{125} \mathrm{I}-\mathrm{t}-\mathrm{PA}$ by unlabeled t-PA was $3 \mathrm{nmol} / \mathrm{L}$ ). This correlates with the fact that the mannose receptor and the LRP are high affinity t-PA receptors. The kd of t-PA binding to the isolated bovine alveolar mannose receptor is $1 \mathrm{nmol} / \mathrm{L}^{34}$ and to rat liver endothelial cells expressing the mannose receptor $4 \mathrm{nmol} / \mathrm{L}$. ${ }^{35}$ With or without PAl-1 involvement, the $\mathrm{kd}$ of $\mathrm{t}-\mathrm{PA}$ binding to LRP ranges from $1-20 \mathrm{nmol} / \mathrm{L}$ on various hepatoma cell lines, ${ }^{20,36-39}$ smooth muscle cells, ${ }^{40}$ and isolated human liver membrane. ${ }^{30}$ In our model, no differences were observed between degradation of t-PA and PPACK-inactivated t-PA. As PPACK-inactivated t-PA has a strongly reduced affinity for plasminogen activator inhibitors, ${ }^{41}$ the results indicate that complex formation is not necessary for binding to either receptor.

Binding of t-PA at $37{ }^{\circ} \mathrm{C}$ (association) was higher than binding at $4{ }^{\circ} \mathrm{C}$, which correlates well with the concept of internalizing ligands and recycling receptors. Indeed, $60-80 \%$ of both LRP and mannose receptor are not expressed on the cell surface of macrophages. ${ }^{42}$ After ligand binding, both receptors are internalized via coated pits. The receptor dissociates in an acidic environment from the ligand and is recycled to the surface, while the ligand is degraded in a lysosome. There is no competition between the mannose receptor and LRP for the internalization apparatus. ${ }^{42,43}$ Lysosomal degradation is chloroquine and $\mathrm{NH}_{4} \mathrm{Cl}$ inhibitable, ${ }^{14,44-46}$ as observed in our model for t-PA degradation.

LRP is already present on monocytes, and variably expressed on macrophages. ${ }^{22,47}$ Monocytes do not express mannose receptors. ${ }^{48,49}$ We found that t-PA degradation by 1-day cultured monocytes was not mannan-inhibitable and that this type of degradation was upregulated on macrophages. Mannose receptor mRNA is known to be expressed after $24 \mathrm{hrs}$ in culture. ${ }^{49}$ Previously functional mannose receptor activities have not been detected before day $3 .{ }^{50,51}$ In our cells, mannose receptor-mediated degradation was observed after 2 days. These differences in expression may be due to culture conditions. ${ }^{25,52,53}$ 
Macrophage mannose receptor-mediated t-PA degradation was 2.5 times upregulated by DEX. Upregulation has also been found for macrophage mannose receptor expression on the mRNA and on the protein level. ${ }^{51,54}$ DEX appeared not to influence LRP-mediated degradation. During LPS stimulation, the mannose receptor was almost not expressed, while LRP was significantly downregulated (five times) after day 3. The downregulation of both receptors by LPS is in line with the observations that LPS downregulates LRP expression after $10 \mathrm{hrs}$ in RAW 264.7 cells ${ }^{55}$ and that mouse macrophage mannose receptors are downregulated after activation. ${ }^{56}$ The time difference in downregulation that we observed is compatible with the finding that the mannose receptor is more susceptible to downregulation during activation of macrophages than the LRP. ${ }^{47}$

Mannan, ovalbumin, mannose-BSA, all known ligands for the mannose receptor, ${ }^{14,42,46,57}$ and a MoAb raised against the isolated human placenta mannose receptor partially inhibited degradation. This proved that degradation was partially mannose receptor-mediated. Degradation of t-PA by macrophages was blocked when mannan and GST-RAP were both present. The 39-kD RAP is a known inhibitor of ligand-LRP interactions. ${ }^{17,58}$ LRP has distinct binding sites for different ligands. RAP does not discriminate between the different binding sites on LRP and inhibits binding of all ligands to the receptor with equal efficiency. ${ }^{17}$ RAP-inhibitable t-PA degradation by smooth muscle cells is not inhibited by fucose, galactose, mannose, or ovalbumin. ${ }^{40} \mathrm{We}$ found an IC50 of $3-5 \mathrm{nmol} / \mathrm{L}$ for the GST-RAP protein on t-PA degradation. This correlates well with the results of $\mathrm{Bu}$ et al., ${ }^{21,59}$ who observed an IC50 of $3.3 \mathrm{nmol} / \mathrm{L}$ for RAP inhibition of t-PA binding to MH1C1 cells expressing LRP, ${ }^{21}$ and a kd of $5 \mathrm{nmol} / \mathrm{L}$ for RAP binding to the LRP on HEP G2 cells. ${ }^{59}$ We concluded that the mannan-inhibitable t-PA degradation by macrophages is mediated by the mannose receptor and non-mannan-inhibitable degradation is mediated by the LRP.

This is the first report that describes LRP and mannose receptor expressed by human primary cultured cells acting independently on the same ligand. The report shows, in addition, that in macrophages, both pathways are equally efficient in mediating t-PA degradation, without involvement of complex formation of t-PA with inhibitors. Macrophage receptor-mediated degradation may play a significant role in local rather than in systemic clearance of t-PA. When active site blocked t-PA is injected intravenously, only low amounts are found in macrophages (bone marrow, spleen). ${ }^{57}$ Nevertheless this human in vitro model seems well suited for evaluating inhibitors of both local and systemic t-PA clearance. Because the major clearance receptors, LRP and mannose receptor, are present, expression can be selectively influenced, and binding can be selectively inhibited.

\section{ACKNOWLEDGEMENT}

This study was financially supported by the Netherlands Heart Foundation grant no. 90.294. 


\section{REFERENCES}

1 Spellman MW, Basa LJ, Leonard CK, Chakel JA, O'Connor JV, Wilson S, Van Halbeek H: Carbohydrate structures of human tissue-type plasminogen activator expressed in Chinese hamster ovary cells. J Biol Chem 264:14100, 1989

2 Otter M, Kuiper J, van Berkel TJC, Rijken DC: Mechanisms of tissue-type plasminogen activator (t-PA) clearance by the liver. Ann NY Acad Sci 667:431, 1992

3 Warshawsky I, Bu G, Schwartz AL: 39-kD protein inhibits tissue-type plasminogen activator clearance in vivo. J Clin Invest 92:937, 1993

4 Andreasen PA, Sottrup-Jensen L, Kjoller L, Nykjaer A Moestrup SK, Munch Petersen C, Gliemann J: Receptormediated endocytosis of plasminogen activators and activator/inhibitor complexes. Febs Letters 338:239, 1994

5 Gordon S: Biology of the macrophage. J Cell Sci Suppl 4:267, 1986

6 Nathan CF: Secretory products of macrophages. J Clin Invest 79:319, 1987

7 Rappolee DA, Werb Z: Macrophage secretions: a functional perspective. Bull Inst Pasteur 87:361, 1989

8 Vassalli J, Dayer J, Wohlwend A, Belin D: Concomitant secretion of prourokinase and of plasminogen activatorspecific inhibitor by cultured human monocytesmacrophages. J Exp Med 159:1653, 1984

9 Collart MA, Belin D, Vassali J, de Kossodo S, Vassali P: Yinterferon enhances macrophage transcription of the tumor necrosis factor/cachectin, interleukin 1 , and urokinase genes, which are controlled by short-lived repressors J Fxp Med 164:2113, 1986

10 Hart PH, Vitti GF, Burgess DR, Singleton DK, Hamilton JA: Human monocytes can produce tissue-type plasminogen activator. J Exp Med 169:1509, 1989

11 Hart PH, Burgess DR, Vitti GF, Hamilton JA: Interleukin-4 stimulates human monocytes to produce tissue-type plasminogen activator. Blood 74:1222, 1989

12 Issekutz TB, Issekutz AC, Movat $\mathrm{HZ}$ : The in vivo quantitation and kinetics of monocyte migration into acute inflammatory tissue. Am J Pathol 103:47, 1981

13 Leibovich SJ, Ross R: The role of the macrophage in wound repair, a study with hydrocortisone and antimacrophage serum. Am J Pathol 78:71, 1975

14 Stahl PD, Schlesinger PH, Sigardson E, Rodman JS, Lee YC: Receptor-mediated pinocytosis of mannose glycoconjugates by macrophages: characterisation and evidence for receptor recycling. Cell 19:207, 1980

15 Browne MJ, Dodd I, Carey JE, Chapman CG, Robinson $\mathrm{JH}$ : Increased yield of human tissue-type plasminogen activator obtained by means of recombinant DNA technology. Thromb Haem 54:422, 1985

16 Kluft C, Van Wezel Al, Van der Velden CAM, Emeis JJ, Verheijen $\mathrm{JH}$, Wijngaards $\mathrm{G}$ : Large scale productions of extrinsic (tissue-type) plasminogen activator from human melanoma cells, in Mizrahi A, Van Wezel Al (eds): Advances in biotechnological Processes, vol 2. New York
USA, Alan R, Liss Inc., 1983, p 97

17 Herz J, Goldstein JL, Strickland DK, Ho YK, Brown MS $39-\mathrm{kDa}$ protein modulates binding of ligands to low density lipoprotein receptor-related protein/a2-macroglobulin receptor. J Biol Chem 266:21232, 1991

18 Weiner RS, Shah VO: Purification of human monocytes: isolation and collection of large numbers of peripheral blood monocytes. J Immunol Meth 36:89, 1980

19 Fraker PJ, Speck JC: Protein and cell membrane iodinations with a sparingly soluble chloramide, 1,3,4,6tetrachloro-3a,6a-diphenylglycoluril. Biochem Biophys Res Commun 80:849, 1978

20 Bu G, Morton PA, Schwartz AL: Identification and partial characterization by chemical cross-linking of a binding protein for tissue-type plasminogen activator (t-PA) on rat hepatoma cells, a plasminogen activator inhibitor type-1 independent t-PA receptor. J Biol Chem 267:15595, 1992

21 Bu G, Williams S, Strickland DK, Schwartz AL: Low density lipoprotein receptor-related protein $/ \alpha_{2}$ macroglobulin receptor is an hepatic receptor for tissuetype plasminogen activator. Proc Natl Acad Sci USA 89:7427, 1992

22 Moestrup SK, Gliemann J, Pallesen G: Distribution of the $\alpha_{2}$-macroglobulin receptor/low density lipoprotein receptorrelated protein in human tissues. Cell Tiss Res 269:375, 1992

23 Nakagawara A, Nathan CF, Cohn ZA: Hydrogen peroxide metabolism in human monocytes during differentiation in vitro. J Clin Invest 68:1243, 1981

24 Fogelman AM, Haberland ME, Seager J, Hokom M, Edwards PA: Factors regulating the activities of the low density lipoprotein receptor and the scavenger receptor on human monocyte-macrophages. J Lipid Res 22:1131, 1981

25 Johnson WD, Mei B, Cohn ZA: The separation, long-term cultivation, and maturation of the human monocyte. J Exp Med 146:1613, 1977

26 Simon DI, Fless GM, Scanu AM, Loscalzo J: Tissue-type plasminogen activator binds to and is inhibited by surfacebound lipoprotein(a) and low-density lipoprotein. Biochemistry 30:6671, 1991

27 Vaughan DE, Mendelsohn ME, Declerck PJ, van Houtte E, Collen D, Loscalzo J: Characterization of the binding of human tissue-type plasminogen activator to platelets. J Biol Chem 264:15869, 1989

28 Bizik J, Stephens RW, Grofova M, Vaheri A: Binding of tissue-type plasminogen activator to human melanoma cells. J Cell Biochem 51:326, 1993

29 Felez J, Changuia CJ, Levin EG, Miles LA, Plow EF: Binding of tissue plasminogen activator to human monocytes and monocytoid cells. Blood 78:2318, 1991

30 Nguyen G, Self SJ, Camani C, Kruithof EKO Characterization of the binding of plasminogen activators to plasma membranes from human liver. Biochem J 287:911, 1992 
31 Felez J, Changuia CJ, Fabregas P, Plow EF, Miles LA; Competition between plasminogen and tissue plasminogen activator for cellular binding sites. Blood 82:2433, 1993

32 Hajjar KA, Nachman RL: The human endothelial cell plasmin-generating system, in Colman RW, Hirsh J, Marder VJ, Salzman EW (eds): Hemostasis and Thrombosis: Basic principles and clinical practice, third ed. JB Lippincott Company, Philadelphia 1994, p 823

33 Parkkinen J, Rauvala $\mathrm{H}$ : Interactions of plasminogen and tissue plasminogen activator (t-PA) with amphoterin enhancement of t-PA catalysed plasminogen activation by amphoterin. J Biol Chem 266:16730, 1991

34 Otter M, Barrett-Bergshoeff MM, Rijken DC: Binding of tissue-type plasminogen activator by the mannose receptor. J Biol Chem 266:13931, 1991

35 Otter M, Kuiper J, Bos R, Rijken DC, van Berkel TJC: Characterization of the interaction both in vitro and in vivo of tissue-type plasminogen activator (t-PA) with rat liver cells. Biochem J 284:545, 1992

36 Wing LR, Bennett $B$, Booth NA: The receptor for tissue plasminogen activator (t-PA) in complex with its inhibitor, PAI-1, on human hepatocytes. FEBS 278:95, 1991

37 Bassel-Duby R, Jiang NY, Bittick T, Madison E, McGooky D, Orth K, Shohet R, Sambrook J, Gething M: Tyrosine 67 in the epidermal growth factor-like domain of tissue-type plasminogen activator is important for clearance by a specific hepatic receptor. J Biol Chem 267:9668, 1992

38 Orth K, Madison EL, Gething M, Sambrook JF, Herz J: Complexes of tissue-type plasminogen activator and its serpin inhibitor plasminogen-activator inhibitor type 1 are internalized by means of the low density lipoprotein receptor-related protein $/ \alpha_{2}$-macroglobulin receptor. Proc Natl Acad Sci USA 89:7422, 1992

39 Nguyen G, Self SJ, Camani C, kruithof EKO: Demonstration of a specific clearance receptor for tissuetype plasminogen activator on rat Novikoff hepatoma cells. J Biol Chem 267:6249, 1992

40 Grobmyer SR, Kuo A, Orishimo M, Okada SS, Cines DB, Barnathan ES: Determinants of binding and internalization of tissue-type plasminogen activator by human vascular smooth muscle and endothelial cells. J Biol Chem 268:13291, 1993

41 Lijnen HR, Van Hoef B, Collen D: On the reversible interaction of plasminogen activator inhibitor-1 with tissuetype plasminogen activator and with urokinase-type plasminogen activator. J Biol Chem 266:4041, 1991

42 McVey Ward D, Ajioka R, Kaplan J: Cohort movement of different ligands and receptors in the intracellular endocytic pathway of alveolar macrophages. J Biol Chem 264:8164, 1989

43 Kaplan J, McVey Ward D: Movement of receptors and ligands through the endocytic apparatus in alveolar macrophages. Am J Physiol 258:L263 1990

44 Goldstein JL, Anderson RGW, Brown MS: Coated pits, coated vesicles, and receptor mediated endocytosis 279:679, 1979
45 Gonzalez-Noriega A, Grubb JH, Talkad V, Sly WS Chloroquine inhibits lysosomal enzyme pinocytosis and enhances lysosomal enzyme secretion by impairing receptor recycling. J Cell Biol 85:839, 1980

46 Praaning-van Dalen D, de Leeuw AM, Brouwer A, Knook DL: Rat liver endothelial cells have a greater capacity than Kuppfer cells to endocytose $\mathrm{N}$-acetylglucosamine- and mannose- terminated glycoproteins. Hepatology 7:672, 1987

47 Imber MJ, Pizzo SV, Johnson WJ, Adams DO: Selective diminution of the trinding of mannose by murine macrophages in the late stages of activation. $\mathrm{J}$ Biol Chem 257:5129, 1982

48 Haltiwanger R : Hill RL: The ligand specificity and tissue localization \& \& rat alveolar macrophage lectin. J Biol Chem 261:156 u, 1986

49 Lennartz MR, Cole FS, Stahl PD: Biosynthesis and processing of the mannose receptor in human macrophages. J Biol Chem 264:2385, 1989

50 Shepherd VL, Campbell EJ, Senior RM, Stahl PD: Characterization of the mannose/fucose receptor on human mononuclear phagocytes. J Reticuloendothel Soc 32:423, 1982

51 Shepherd VL, Konish MG, Stahl P: Dexamethasone increases expression of mannose receptors and decreases extracellular lysosomal enzyme accumulation in macrophages. J Biol Chem 260:160, 1985

52 Moaz H, Polliack A, Barak V, Yatziv S, Biran S, Giloh H, Treves A: Parameters affecting the in vitro maturation of human monocytes to macrophages. Int $\mathrm{J}$ Cell Cloning 4:167, 1986

53 Clohisy DR, Chappel JC, Teitelbaum SL: Bone-marrow derived mononuclear phagocytes autoregulate mannose receptor expression. J Biol Chem 264:5370, 1989

54 Cowan HB, Vick JT, Shepherd VL: Dexamethasone upregulates mannose receptor activity by increasing mRNA levels. Arch Biochem Biophys 296:314, 1992

55 Lamarre J, Wolf BB, Kittler ELW, Quesenberry PJ, Gonias SL: Regulation of Macrophage $a_{2}$-Macroglobulin receptor/low density lipoprotein receptor related protein by lipopolysaccharide and interferon-y. J Clin Invest 91:1219, 1993

56 Ezekowitz RAB, Gordon S: Down-regulation of mannosyl receptor-mediated endocytosis and antigen $F 4 / 80$ in bacillus Calmette-Guerin-activated mouse macrophages. J Exp Med 155:1623, 1982

57 Hasapes JP, Daugherty A, Saffitz JE, Sobel BE: Determinants of the distribution of radiolabeled congeners of tissue-type plasminogen activator and its modification for improved clot imaging. Cor Artery Dis 3:641, 1992

58 Herz J: The LDL-receptor-related protein- portrait of a multifunctional receptor. Curr Opin Lipidol 4:107, 1993

59 Bu G, Maksymovitch EA, Schwartz AL: Receptor-mediated endocytosis of tissue-type plasminogen activator by low density lipoprotein receptor-related protein on human hepatoma Hep G2 cells. J Biol Chem 268:13002, 1993 


\section{CHAPTER 3}

Monoclonal antibodies against the human mannose receptor that inhibit the binding of tissue-type plasminogen activator.

Marrie Barrett-Bergshoeff, Femke Noorman, Rogier Bos, and Dingeman C. Rijken.

Gaubius Laboratory, TNO Prevention and Health,

Leiden, The Netherlands.

Reproduced from

Thrombosis and Haemostasis, 1997, 77:718-724 


\section{SUMMARY}

To study the role of the mannose receptor in cellular uptake and degradation of tissue-type plasminogen activator (t-PA), a set of five monoclonal antibodies (Moab) was generated against the mannose receptor isolated from human placental tissue.

All Moab specifically recognised the $175 \mathrm{kDa}$ mannose receptor in a crude placenta extract, as shown in Western blot analysis. By use of immunohistochemistry, we showed that in human placenta only the Hofbauer cells (fetal macrophages) express the mannose receptor. Epitope competition experiments indicated that the Moab bound to at least two different epitopes on the receptor molecule. Moab 14-3, 14-5, and 15-2, which are directed against one of these epitopes, strongly inhibited the interaction between the purified mannose receptor and t-PA. These Moab also inhibited mannose receptormediated degradation of t-PA by cultured human macrophages. The low density lipoprotein receptorrelated protein (LRP) mediated t-PA degradation was not affected by the Moab.

It is concluded that the Moab are useful for studying the expression of the human mannose receptor in Western blot and in immunohistochemistry, and for studying the interactions between the human mannose receptor and the mannose-containing ligand t-PA.

\section{INTRODUCTION}

The macrophage mannose receptor binds pathogens expressing polymannose structures, and glycoproteins bearing high mannose-type oligosaccharides. After binding the ligand is internalised and degraded in the lysosomes. ${ }^{1}$ This receptor is also expressed by liver endothelial cells where it mediates the very rapid endocytosis of its ligands. ${ }^{2}$ The receptor contains eight so-called carbohydrate recognition domains. At least three of these domains have mannose-binding properties. ${ }^{3-5}$

Tissue-type plasminogen activator (t-PA) is a serine protease that activates fibrinolysis by converting plasminogen to plasmin which cleaves fibrin to soluble degradation products. ${ }^{6,7}$ Because of its fibrinselective action, t-PA is successfully used for thrombolytic therapy. ${ }^{8,9}$ Recombinant t-PA contains one high-mannose- and one or two complex-type oligosaccharides. ${ }^{10} \mathrm{It}$ is rapidly cleared from the circulation by both the mannose receptor and the low density lipoprotein receptor-related protein (LRP). ${ }^{11-14}$ An inhibitor blocking the mannose receptor mediated t-PA degradation could increase t-PA concentrations in blood and thereby stimulate fibrinolysis and thrombolysis.

Ligands for the mannose receptor such as polymannose products (mannan), mannosylated BSA or ovalbumin are good inhibitors of t-PA binding and degradation, ${ }^{12.15-17}$ but they may also bind to other mannose binding proteins and may interfere with the function of these binding proteins in vivo. ${ }^{18-19}$ Monoclonal antibodies might be used to block specifically the mannose receptor, but monoclonal antibodies against this receptor have not yet been described. 
We generated monoclonal antibodies (Moab) against the mannose receptor isolated from human placenta. We used these Moab as specific markers for human macrophages using flow cytometry and immunohistochemistry. ${ }^{20}$ In the present study we used immunohistochemistry to identify the mannose receptor expressing cells in human placenta from which the receptor was isolated. We studied whether the Moab were able to bind to the mannose receptor and inhibit t-PA binding to the receptor. Furthermore we evaluated whether the Moab were able to inhibit t-PA degradation by human macrophages which are known to express the mannose receptor and the LRP. ${ }^{15}$

\title{
MATERIALS AND METHODS
}

\begin{abstract}
Monoclonal antibodies
Mannose receptor was isolated and purified from human placenta on a mannosylated-albumin-Sepharose column, ${ }^{21,22}$ essentially as described earlier. ${ }^{23.24}$ Female BALB/c mice were immunised three times, at four-weekly intervals, with $20 \mu \mathrm{g}$ of purified human mannose receptor. The serum was tested for the presence of antibodies against the mannose receptor in an enzyme linked immunosorbent assay (ELISA) and for the presence of inhibiting antibodies in a t-PA binding assay as described below. All mice immunised had antibodies against the mannose receptor when tested in the ELISA, and all sera contained inhibiting antibodies when tested in the t-PA binding assay.
\end{abstract}

\section{Cell fusion}

Fusion was performed essentially as described earlier. ${ }^{25,26}$ Splenocytes $\left(9 \times 10^{7}\right)$ were fused with SP2/0 Ag.14 myeloma cells using $50 \%$ polyethylene glycol 4000 (Boehringer Mannheim, Mannheim, Germany). The cell suspension was diluted in culture medium: Dulbecco's modified Eagle medium (Gibco, Paisley, Scotland) supplemented with $10 \% \mathrm{v} / \mathrm{v}$ fetal calf serum containing hypoxantine $(100 \mu \mathrm{M})$, aminopterin $(0.4 \mu \mathrm{M})$, thymidine $(16 \mu \mathrm{M})$ and $10 \%(\mathrm{~V} / \mathrm{V})$ human umbilical vein endothelial cell supernatant (a gift from Dr. P. Koolwijk, produced at our laboratory). The cells were then divided over 96-well microtitre plates (Costar, Cambridge, MA, USA) at a concentration of $0.6 \times 10^{5}$ splenocytes/well and cultured at $37^{\circ} \mathrm{C}$ in a humidified incubator under $7.5 \% \mathrm{CO}_{2}$. Media of growing cells were screened for antibody production in the ELISA as described below. Cells from positive wells were subcloned by limiting dilution. Positive clones were grown in culture medium and frozen in medium containing $10 \%(\mathrm{~V} / \mathrm{V})$ DMSO at a concentration of $6 \times 10^{6}$ to $10^{7}$ cells $/ \mathrm{ml}$.

\section{Production, purification and subclass assessment of the monoclonal antibodies (Moab)}

Large quantities of Moab were obtained by in vivo (ascites) production in pristane-primed female BALB/c mice. Moab from ascitis in 3.3 M NaCl, $1.5 \mathrm{M}$ glycine, pH 8.9 were bound to a Protein A-Sepharose column (Pharmacia, Uppsala, Sweden), and eluted with $0.1 \mathrm{M}$ citrate at $\mathrm{pH}$ 4.5. Pooled Moab fractions were dialysed against $20 \mathrm{mM} \mathrm{Tris} / \mathrm{HCl}, \mathrm{pH} 7.4,150 \mathrm{mM} \mathrm{NaCl}, 5 \mathrm{mM} \mathrm{CaCl}$. The heavy and light chain subclass of the Moab were assessed by using a Mouse Isotyping kit from Gibco (Paisley, Scotland) according to the manufacturer's instructions.

\section{Western blotting of the mannose receptor}

Purified mannose receptor or crude placenta extract ${ }^{24}$ was run on $6 \%$ SDS polyacrylamide gels under non-reducing conditions. After electrophoresis the gels were blotted overnight at room temperature at $150 \mathrm{~mA}$ on nitrocellulose paper in $50 \mathrm{mM}$ borate buffer $\mathrm{pH} 8.0$ containing $10 \%$ methanol. Blots were incubated for $2 \mathrm{~h}$ with buffer $(20 \mathrm{mM} \mathrm{Tris} / \mathrm{HCl} \mathrm{pH} 7.4,150 \mathrm{mM} \mathrm{NaCl}, 5 \mathrm{mM} \mathrm{EDTA}, 0.5 \%$ Tween $80,1 \mathrm{mg} / \mathrm{ml} \mathrm{BSA}$ ). The blotting paper was then incubated for $2 \mathrm{~h}$ with Moab, and subsequently stained with rabbit-anti-mouse polyclonal IgG peroxidase (Nordic, Tilburg,The Netherlands) and BM blue (Boehringer Mannheim, Mannheim, Germany)

\section{Immunohistochemistry}

Placenta tissue was obtained from the Department of Pathology, Slotervaart Hospital, Amsterdam, and snap frozen in liquid nitrogen. As described earlier ${ }^{20}$ sections of $8 \mu \mathrm{m}$ thickness were cut on a Reichert-Jung 2800 frigocut cryostat, transferred to poly-L-lysine coated microscope slides, air-dried and fixed in acetone (10 min room temperature), rinsed in PBS and incubated with $1 \mu \mathrm{g} / \mathrm{ml} \mathrm{Moab}$ 15-2 for $30 \mathrm{~min}$ at room temperature. After rinsing in PBS (5 $\mathrm{min})$, the sections were incubated with an rabbit-anti-mouse-alkaline phosphatase (Dako AV, Glostrup, Denmark) for $15 \mathrm{~min}$ at room temperature, rinsed with PBS (5 min) and incubated for 30 min at room temperature in the dark with naphtol-AS-MX-phosphate (Sigma Chemical Co., St.Louis MO, USA) and New Fuchsine (Chroma Gezellschaft, Köngen, BRD) as a coupling salt to develop a red reaction product. Finally, the sections were rinsed with aqua dest, counterstained with Mayers hematoxilin and mounted in DePeX mounting medium (BDH, Poole, U.K.). In control sections, no primary antibody was used. The identity of the cells was judged on the basis of their morphology and location in the tissue. 


\section{Labelling of Moab and t-PA}

Tissue-type plasminogen activator (t-PA), was purified from a recombinant human melanoma cell culture ${ }^{27}$ by Dr. J.H. Verheijen. ${ }^{28} \mathrm{t}-$ $\mathrm{PA}$ and Moab at concentrations of respectively 0.1 and $1 \mathrm{mg} / \mathrm{ml}$, were dialysed against $0.1 \mathrm{M} \mathrm{NaHCO}_{3}, 0.01 \% \mathrm{v} / \mathrm{V}$ ween $80, \mathrm{pH} 8.5$ and incubated with NHS-biotin (Zymed Laboratories Inc., South San Francisco, CA, USA) at $30^{\circ} \mathrm{C}$ (t-PA) or at room temperature (Moab) for $3 \mathrm{~h}$ at different molar ratios. Molar ratios of ligand to NHS-biotin were 1:200 for t-PA and 1: 100 for the Moab. After incubation the ligands were dialysed against $20 \mathrm{mM}$ Tris/ $\mathrm{HCl}$ buffer, $\mathrm{pH} 7.4$ containing $150 \mathrm{mM} \mathrm{NaCl}, 5 \mathrm{mM} \mathrm{CaCl}$ and $0.01 \%(\mathrm{v} / \mathrm{V})$ Tween 80 .

For degradation studies, $t$-PA was labelled with ${ }^{125}$ I using the iodogen method as described earlier. ${ }^{15}$ Labelling resulted in approximately $600 \mathrm{cpm} / \mathrm{fmol}$, with $80 \%$ recovery of t-PA activity.

\section{ELISA for mannose receptor antibodies}

Polystyrene microtitre plates (Greiner, Frickenhausen, Germany) were coated overnight at $4^{\circ} \mathrm{C}$ with $100 \mu \mathrm{l} 0.015 \mu \mathrm{g} / \mathrm{ml}$ detergent-free mannose receptor in $20 \mathrm{mM}$ Tris/ $\mathrm{HCl}$ buffer, $150 \mathrm{mM} \mathrm{NaCl}, 5 \mathrm{mM} \mathrm{CaCl}_{2}, \mathrm{pH}$ 7.4. From here onwards the assay was performed at room temperature. The wells were incubated for $0.5 \mathrm{~h}$ with "binding buffer" $(20 \mathrm{mM}$ Tris/ $/ \mathrm{HCl}, \mathrm{pH} 7.4$ containing $0.5 \%(\mathrm{v} / \mathrm{V}) \mathrm{Tween} 80$, $150 \mathrm{mM} \mathrm{NaCl}, 5 \mathrm{mM} \mathrm{CaCl}_{2}$, and $1 \mathrm{mg} / \mathrm{ml} \mathrm{BSA}$ ) and incubated for $1 \mathrm{~h}$ with antibodies against the mannose receptor in binding buffer. Bound antibodies were quantified by incubation with peroxidase-conjugated rabbit anti-mouse immunoglobulin (Nordic, Tilburg, The Netherlands) diluted in binding buffer. Between each incubation step the wells were washed 3 times with binding buffer. Bound conjugate was detected by conversion of the chromogenic substrate $3,3^{\prime}, 5,5^{\prime}$-tetramethylbenzidine in the presence of $\mathrm{H}_{2} \mathrm{O}_{2} \cdot{ }^{29} \mathrm{The}$ results were corrected for non-specific binding obtained in wells which were "coated" with buffer without mannose receptor.

\section{Epitope competition assay}

To determine whether some of the Moab react with the same or different epitopes on the receptor molecule, we studied the inhibition of labelled Moab binding to the receptor by unlabelled Moab. Plates were coated with mannose receptor as described for ELISA. From here onwards the assay was performed at room temperature. Moab at concentrations of about 1, 10 and 100 times the concentration required for half maximal binding $\left(\mathrm{EC}_{50}\right.$, see Table 1) in the ELISA, were preincubated for 30 min. Then biotinylated Moab was added at a non-saturating concentration ( 2 times $\mathrm{EC}_{50}$ ) and residual binding was measured after $1 \mathrm{~h}$ as described for the ligand binding assay (see below).

\section{t-PA binding assay and inhibition by antisera and Moab}

Binding of t-PA to immobilised mannose receptor was performed essentially as described earlier. ${ }^{21}$ Briefly, mannose receptor $(100 \mu l$ $0.15 \mu \mathrm{g} / \mathrm{mi}$ ) in $20 \mathrm{mM}$ Tris/ $\mathrm{HCl}$ buffer, $150 \mathrm{mM} \mathrm{NaCl}, 5 \mathrm{mM} \mathrm{CaCl}, \mathrm{pH} 7.4$ was adsorbed overnight at $4^{\circ} \mathrm{C}$ to polyvinyl chloride microtitre plates (Flow Laboratories). The wells were incubated for $0.5 \mathrm{~h}$ at room temperature with binding buffer. Inhibition of t-PA binding by antisera or Moab was measured by preincubation of the immobilised receptor with varying concentrations of antibodies in binding buffer for $0.5 \mathrm{~h}$. Subsequently a nonsaturating concentration of biotinylated t-PA ( $100 \mathrm{ng} / \mathrm{ml}$, final concentration) was added and the mixture was incubated at room temperature for $2 \mathrm{~h}$. Bound ligand was quantified by incubation at room temperature for $1 \mathrm{~h}$ with alkaline phosphatase-conjugated streptavidine (Amersham, Buckinghamshire, UK). Between each incubation step the wells were washed 3 times with binding buffer. Bound conjugate was detected by measuring the conversion rate of the chromogenic substrate p-nitrophenyl phosphate (Sigma, St. Louis, MO, USA) at $25^{\circ} \mathrm{C}$. The results were corrected for non-specific binding obtained in wells which were "coated" with buffer without mannose receptor.

\section{Monocyte isolation and cultivation}

Monocytes were isolated from pooled human buffy coats as described earlier. ${ }^{15}$ Buffy coat (100 ml) was diluted with $180 \mathrm{ml}$ phosphate buffer $\left(4.5 \mathrm{mM} \mathrm{KCl}, 228 \mathrm{mM} \mathrm{NaCl}, 13.5 \mathrm{mM} \mathrm{Na}_{2} \mathrm{HPO}_{4}, 2.5 \mathrm{mM} \mathrm{KH}_{2} \mathrm{PO}_{4}\right.$, pH 7.4) containing 10 units/ml of heparin. Portions of $35 \mathrm{ml}$ suspension were underlayered with $14 \mathrm{ml}$ Lymphoprep $^{T M}$ (Nycomed Pharma AS, Oslo, Norway). After $30 \mathrm{~min}$ centrifugation at $800 \mathrm{~g}$, the interface was collected, and washed $(250 \mathrm{~g}, 10 \mathrm{~min})$ twice with phosphate-buffered saline (PBS: $2.7 \mathrm{mM}$

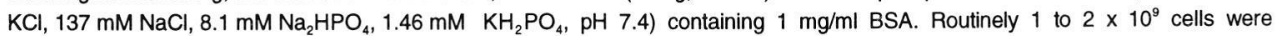
obtained. This cell suspension was further purified using countercurrent flow centrifugation (elutriation). ${ }^{15}$ Elutriation-purified monocytes (approximately 1 to $2 \times 10^{8}$ cells, $85 \%$ CD14 positive cells) were washed with PBS and re-suspended in culture medium (M199 containing $10 \mathrm{mg} / \mathrm{ml}$ glutamine, $50 \mathrm{U} / \mathrm{ml}$ penicillin, $50 \mu \mathrm{g} / \mathrm{ml}$ streptomycin, $10 \%$ human $\mathrm{AB}^{+}$serum). Cells were cultured at a concentration of $2 \times 10^{6} \mathrm{cell} / \mathrm{s} / \mathrm{ml}$ in 24 well culture plates and used on the third day for t-PA degradation studies.

\section{Degradation of ${ }^{125}$ I-t-PA by macrophages}

As described earlier ${ }^{15}$ monocytes cultured for 2-7 days on plastic culture plates differentiate and become macrophages. Macrophages were washed three times with PBS $\left(4^{\circ} \mathrm{C}\right)$ containing $10 \mathrm{mg} / \mathrm{ml} \mathrm{BSA}, 0.9 \mathrm{mM} \mathrm{CaCl} 2$ and $0.5 \mathrm{mM} \mathrm{MgCl}$, and incubated for $3 \mathrm{~h}$ with $1 \mathrm{nM}{ }^{125} \mathrm{I}-\mathrm{t}-\mathrm{PA}$, with or without inhibitors in $300 \mu \mathrm{l} \mathrm{M199,} 10 \mathrm{mg} / \mathrm{ml} \mathrm{BSA}, 0.01 \%$ Tween 80 , at $37^{\circ} \mathrm{C}$ in $5 \% \mathrm{CO}_{2} / 95 \%$ air. Mannan extracted from Saccharomyces cerevisiae, prepared by the cetavlon method (Sigma St. Louis MO, USA) was used to inhibit 
mannose receptor-mediated degradation. In some experiments, receptor associated protein (RAP) was used to inhibit LRP mediated t-PA degradation ${ }^{15}$ (prepared at our laboratory by Dr. J.H. Verheijen, using a Salmonella japonicum glutathione-S-transferase (GST)RAP expression plasmid which was kindly provided by Dr. J. Herz, University of Texas, Southwestern Medical Center, Dallas, USA). After incubation, cell media were collected and trichloroacetic acid (TCA) was added (final concentration 10\% w/V). Non-degraded ${ }^{125}$ I-t-PA was precipitated by centrifugation $(10 \mathrm{~min} 15,000 \mathrm{~g}$ ). To eliminate the possibility that the cells might deiodinate rather than degrade ${ }^{125} \mathrm{I}$-t-PA, free ${ }^{125} \mathrm{I}$ was extracted. To $500 \mu \mathrm{l} \mathrm{TCA}$ soluble supernatant obtained, $5 \mu \mathrm{l} 40 \%$ (W/V) KI and $25 \mu \mathrm{l} \mathrm{H}_{2} \mathrm{O}_{2} 30 \%(\mathrm{~V} / \mathrm{N})$ were added. After $5 \mathrm{~min}$, the free iodine was extracted with $800 \mu \mathrm{l}$ chloroform. The radioactivity of the remaining ${ }^{125}$-tyrosine (and possibly ${ }^{125} \mathrm{I}$-peptides) in the upper layer after centrifugation $\left(5 \mathrm{~min} 15,000 \mathrm{~g}\right.$ ) representing degraded ${ }^{125} \mathrm{I}$-t-PA was determined. Degradation was corrected for radioactivity determined in parallel wells without macrophages $(<5 \%)$.

\section{Statistics}

Binding of ligand to the mannose receptor was measured at increasing concentrations of ligand, and plotted against the log of the ligand concentration (binding curve). For inhibition curves, a concentration range of inhibitor with one nonsaturating concentration of labelled ligand was added to the receptor, and the residual binding was measured and plotted against the log of the inhibitor ccncentration. The sigmoidal binding and inhibition curves were analysed using nonlinear regression analysis with the computer program GraphPAD (ISI Software, Philadelphia, PA, USA), yielding half maximal binding concentration (log $\mathrm{EC}_{50}$ ) or half maximal inhibitory concentration $\left(\log I \mathrm{C}_{50}\right)$ and their standard error. When at high inhibitor concentration only partial inhibition was observed, the $I_{50}$ was calculated as the concentration inhibitor where half of the maximal inhibition was observed. "Goodness of fit" was assessed by evaluating the actual distance of the measurements from the fitted line (no weighing).

\section{RESULTS}

Five stable cell lines were found and characterised after subcloning, and will be referred to as: $14-2,14-$ $3,14-5,15-2$ and 15-14. All five were isotyped as Moab of the $\operatorname{lgG}_{1}$ subclass with kappa-light chains.

\section{Western blotting}

All Moab recognised the purified $175 \mathrm{kDa}$ mannose receptor after SDS-PAGE and transfer to nitrocellulose (Fig 1). In order to study the specificity of the Moab, binding of the Moab to a crude placenta extract from which the receptor was originally purified was analysed. Fig 1 shows that all Moab stained the $175 \mathrm{kDa}$ mannose receptor present in the extract. Moab 14-5 and 15-2 did not stain other proteins. Moab 14-3, 15-14 and 14-2, which were used at higher concentrations than 14-5 and 15-2, showed three additional bands. These bands were also visible with a control Moab not prepared against the mannose receptor at a similar concentration, indicating that they could probably be ascribed to lowaffinity- specific or non-specific IgG binding.

\section{Fig 1}

SDS PAGE and Western blotting of purified mannose receptor $( \pm 200 \mathrm{ng}$ protein) and crude placenta extract ( $\pm 160 \mu \mathrm{g}$ protein) with the various Moab.

The following Moab were used at concentrations that were sufficiently high to saturate the mannose receptor (see Fig 3). Lanes 1: Moab 14-3 (10 $\mu \mathrm{g} / \mathrm{ml})$; lanes 2: Moab 14-5 (1 $\mu \mathrm{g} / \mathrm{ml})$; lanes 3: Moab 15-2 $(0.1 \mu \mathrm{g} / \mathrm{ml})$; lanes 4 : Moab 15-14 (300 $\mu \mathrm{g} / \mathrm{ml})$; lanes 5: Moab 14-2 (50 $\mu \mathrm{g} / \mathrm{ml})$; lanes 6: negative control Moab $(150 \mu \mathrm{g} / \mathrm{ml})$; lane 7 : buffer. The position of the $175 \mathrm{kDa}$ mannose receptor is indicated.

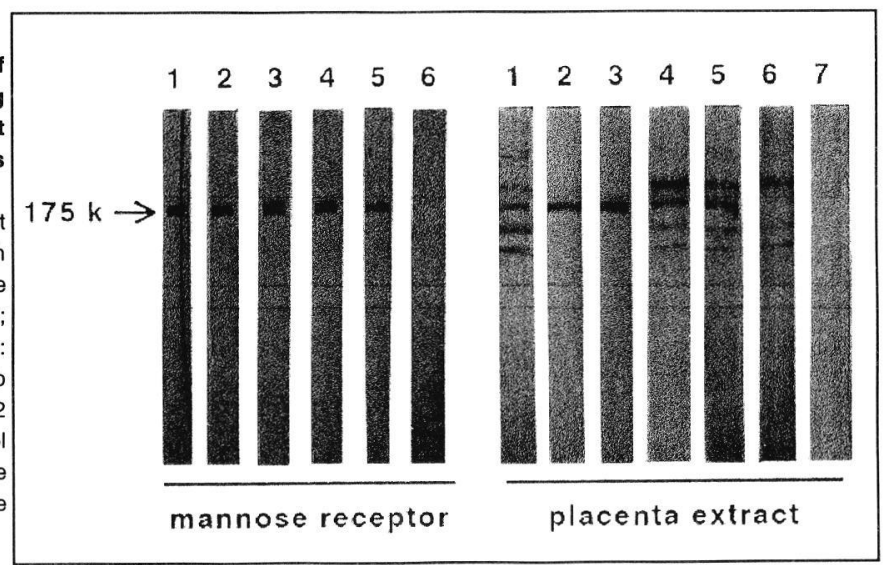




\section{Immunohistochemistry}

The Moab presented in this study were also successfully used as specific markers for human macrophages in flow cytometry and in immunohistochemistry. ${ }^{20}$ In the present study we used Moab 15-2 to visualize the cells expressing the mannose receptor in human placenta. As shown in Fig 2 (see appendix, page 137), only the Hofbauer cells (fetal macrophages) stained positive for the mannose receptor in human placenta.

\section{ELISA and epitope competition.}

The extent of binding of each Moab to the isolated mannose receptor was concentration dependent with $\mathrm{EC}_{50}$ values ranging between 0.008 and $4.9 \mu \mathrm{g} / \mathrm{ml}$ (Fig 3, Table 1).

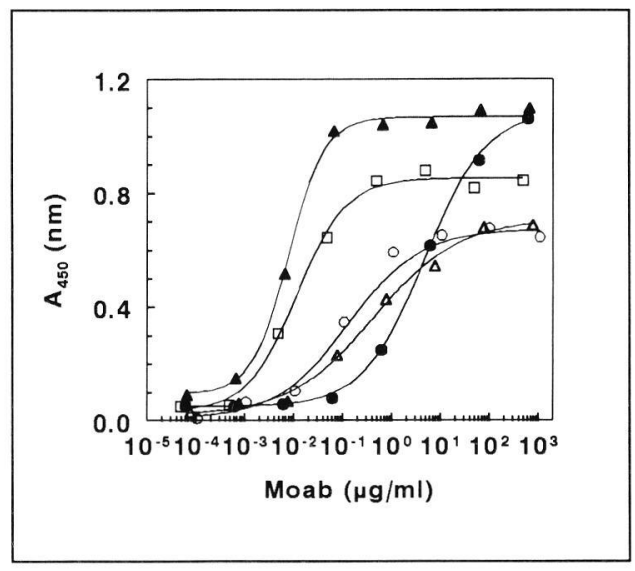

Fig 3 ELISA with monoclonal antibodies.

Dose-response curves of Moab binding to the immobilised isolated mannose receptor, detected with peroxidaseconjugated rabbit anti-mouse IgG. Mean of duplicate measurements are shown. Moab 14-3 (O), Moab 14-5 (口),

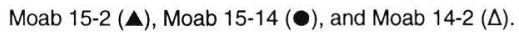

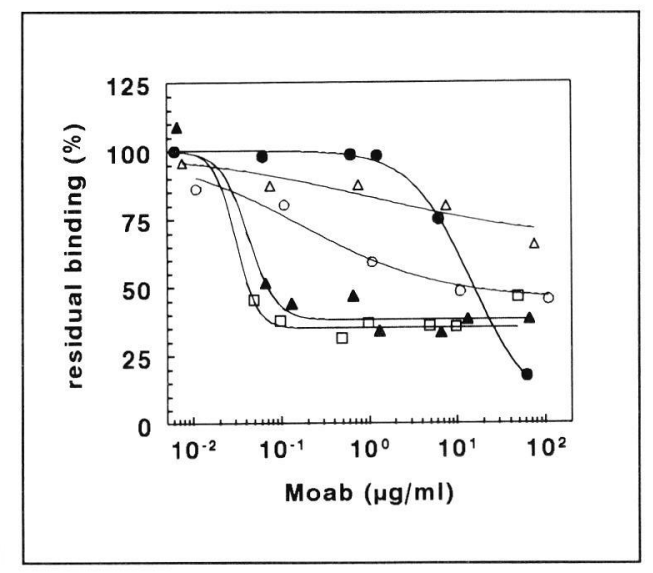

Fig 4 Inhibition of t-PA binding to the mannose receptor. Effect of Moab on the binding of $0.1 \mu \mathrm{g} / \mathrm{ml}$ biotinylated t-PA to the mannose receptor. Immobilised receptor was preincubated with the Moab, ligand was added, residual binding of the ligand was measured and the inhibition percentage was calculated. Mean of duplicate measurements are shown. Moab 14-3 (O), Moab 14-5 (ㅁ), Moab 15-2 (A), Moab 15-14(•), Moab 14-2 $(\Delta)$.

Results of the epitope competition assay showed that the five Moab bound to at least two different epitopes on the mannose receptor molecule (Table 2). Three Moab (14-3, 14-5, 15-2) apparently recognised the same epitope (epitope cluster I), since they mutually competed for binding to the mannose receptor. A different epitope (epitope cluster II) was recognised by Moab 15-14 and 14-2, they inhibited each other's binding and their binding was not inhibited by 14-3, 14-5 or 15-2. Moab 15-14 however did inhibit subsequent binding of cluster I Moab. This effect cannot be explained by competitive inhibition (which is by definition a mutual effect). Moab 15-14 could have bound to both epitopes and thereby have inhibited the binding of all other Moab but in that case both epitope clusters Moab would have inhibited Moab 15-14 binding partially and a higher signal would have been observed for Moab 1514 in the ELISA (Fig 3). More probably Moab 15-14 had an effect on the conformation of the receptor resulting in noncompetitive inhibition. ${ }^{30}$ 


\section{Inhibition of $t$-PA binding.}

In Fig 4 Moab inhibition of t-PA binding to the mannose receptor is shown. Even at high Moab concentrations $(1-100 \mu \mathrm{g} / \mathrm{ml})$, which according to the model of competitive inhibition ${ }^{30}$ should have inhibited binding for approximately $95 \%$, only partial inhibition was observed. Cluster I Moab inhibited tPA binding by about $60 \%$. Cluster II Moab $14-2$ showed only slight inhibition (maximally $30 \%$ ) whereas Moab 15-14 strongly inhibited t-PA binding at high concentrations. Table 1 summarizes the $I_{50}$ values for the various Moab and shows that these values agree well with the $\mathrm{EC}_{50}$ obtained in the ELISA (Fig 3 ). In both assays Moab 15-2 and 14-5 showed the highest affinity and Moab 15-14 the lowest affinity for the mannose receptor.

Table 1 Mannose receptor affinities of Moab functioning as ligand or inhibitor. The affinities of the Moab towards the mannose receptor were measured when the Moab were used as ligand in the ELISA ( $E_{50}$, see Fig 3 ) and as inhibitor in the t-PA binding assay $\left(\mathrm{IC}_{50}\right.$, see Fig 4).

\begin{tabular}{|crcrc|}
\hline ligand/inhibitor & \multicolumn{2}{c|}{ ELISA } & t-PA binding assay \\
\cline { 2 - 5 } & $\begin{array}{c}\mathrm{EC}_{50} \\
\mu \mathrm{g} / \mathrm{ml}\end{array}$ & $\begin{array}{c}\text { log EC } \\
\pm \text { standard } \text { error }\end{array}$ & $\begin{array}{c}\text { IC }_{50} \\
\mu \mathrm{g} / \mathrm{ml}\end{array}$ & $\begin{array}{c}\text { log }_{\text {IC }} \\
\pm \text { standard error }\end{array}$ \\
\hline $14-3$ & 0.13 & $-0.88 \pm 0.16$ & 0.18 & $-0.74 \pm 0.15$ \\
$14-5$ & 0.012 & $-1.91 \pm 0.10$ & 0.031 & $-1.51 \pm 0.28$ \\
$15-2$ & 0.008 & $-2.09 \pm 0.04$ & 0.043 & $-1.37 \pm 0.24$ \\
$15-14$ & 4.9 & $0.69 \pm 0.05$ & 15 & $1.17 \pm 0.03$ \\
$14-2$ & 0.44 & $-0.35 \pm 0.15$ & 1.1 & $0.02 \pm 0.37$ \\
\hline
\end{tabular}

Table 2 Moab competition for epitopes on the mannose receptor. Immobilised mannose receptor was incubated with a nonsaturating concentration of labelled Moab and a concentration range of nonlabelled Moab. Residual binding of the biotinylated Moab (indicated by *) was measured. Inhibition at a concentration of 100 times $\mathrm{EC}_{50}$ (see table 1) of the inhibiting Moab is shown.

\begin{tabular}{|cccccc|}
\hline Moab & $14-3^{*}$ & $14-5^{*}$ & $15-2^{*}$ & $15-14^{*}$ & $14-2^{*}$ \\
\hline $14-3$ & + & + & + & $=$ & $=$ \\
$14-5$ & + & + & + & $=$ & $=$ \\
$15-2$ & + & + & + & + & + \\
$15-14$ & + & + & + & + & + \\
$14-2$ & $=$ & $=$ & $=$ & + \\
\hline
\end{tabular}

+ represents inhibition $>40 \%$; = represents inhibition $<15 \%$. 


\section{Inhibition of t-PA degradation by macrophages.}

Cultured macrophages internalise and degrade t-PA after binding to the mannose receptor or LRP. LRP mediated degradation is inhibitable with the receptor-associated protein (GST-RAP), while mannose receptoor mediated t-PA degradation is inhibitable with mannan. ${ }^{15}$ This model was used to test whether the Moab were able to inhibit mannose receptor mediated t-PA degradation. As shown in Fig $5 \mathrm{~A}$, mannan inhibited total t-PA degradation by $51 \%$ and $10 \mu \mathrm{g} / \mathrm{ml} \mathrm{Moab} 14-5$ by $44 \%$. The combination of mannan and Moab 14-5 did not show any additional inhibition of total t-PA degradation, indicating that the LRP mediated degradation was not affected by Moab 14-5. GST-RAP ( $25 \mathrm{nM}$ ) inhibited total t-PA degradation by $40 \%$. t-PA degradation was inhibited with a combination of GST-RAP and mannan by $91 \%$ and with a combination of GST-RAP and $10 \mu \mathrm{g} / \mathrm{ml}$ Moab $14-5$ by $87 \%$. Fig 5B shows that inhibition by Moab 14-5 was concentration-dependent and reached at $10 \mu \mathrm{g} / \mathrm{ml}$ about $90 \%$ of mannan inhibition in both the presence and absence of GST-RAP. At concentrations of $1 \mathrm{ng} / \mathrm{ml}$ to $10 \mu \mathrm{g} / \mathrm{ml}$ Moab $15-14 \mathrm{did}$ not show an inhibitory effect. Moab 14-3 and 14-2 caused an intermediate inhibitory effect (respectively $39 \pm 7 \%$ and $29 \pm 16 \%$ at $10 \mu \mathrm{g} / \mathrm{ml}$ ), while $15-2$ strongly inhibited mannan inhibitable t-PA degradation $(68 \pm 4 \%$ at $10 \mu \mathrm{g} / \mathrm{ml})$ (not shown).

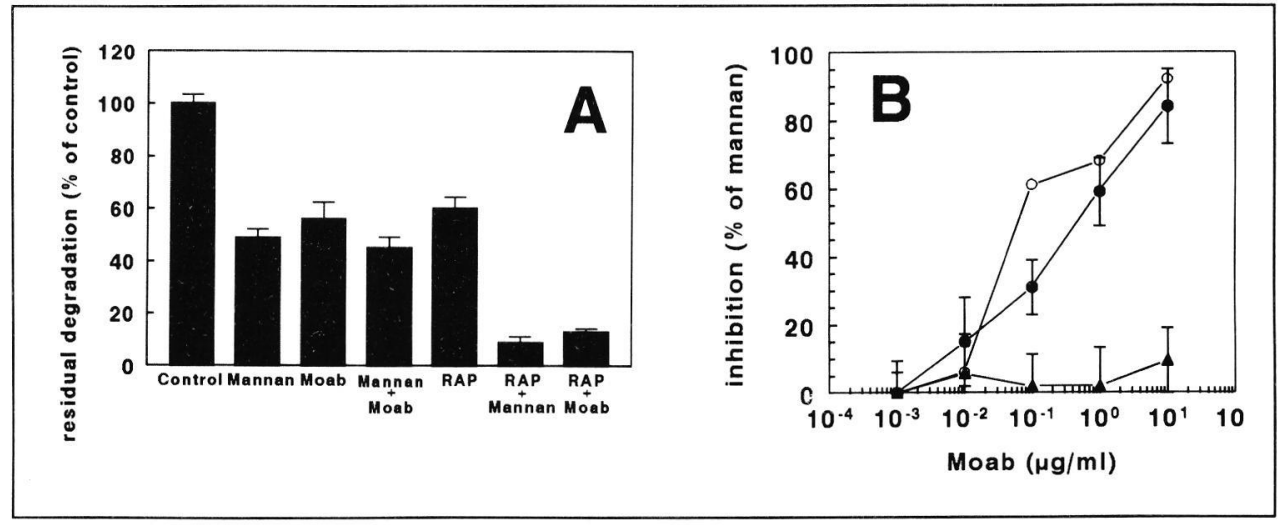

Fig 5 Inhibition of macrophage t-PA degradation by Moab 14-5.

Effect of the Moab on ${ }^{125} \mathrm{l}$-labelled t-PA degradation by human monocyte derived macrophages. Residual degradation (\% of control, $\mathrm{n}=6$, mean \pm SEM) was measured in the absence or presence of $1 \mathrm{mg} / \mathrm{ml}$ mannan, $10 \mu \mathrm{g} / \mathrm{ml}$ Moab $14-5,25 \mathrm{nM}$ GST-RAP or their combinations (A). The concentration-dependent effect of the Moab expressed as a percentage of $1 \mathrm{mg} / \mathrm{ml}$ mannan inhibition is shown in B. Mannose receptor mediated t-PA degradation in the presence of Moab 14-5 ( ) , n=6, mean \pm SEM, in the presence of Moab 14-5 combined with $25 \mathrm{nM}$ GST-RAP $(O), n=2$, mean, or in the presence of Moab 15-14 (A), $n=6$, mean \pm SEM. 


\section{DISCUSSION}

Five stable cell lines producing Moab with different affinities for the human mannose receptor were obtained. These Moab all reacted in a crude placenta extract with the $175 \mathrm{kDa}$ mannose receptor as shown by the use of Western blot. In another study, we used the Moab to reveal the presence of the mannose receptor on cultured human macrophages using flow cytometry, and showed that with this method we were able to measure different levels of mannose receptor expression. ${ }^{20}$ Furthermore we used Moab 14-5 and 15-2 to detect the mannose receptor expressing cells in cryostat sections of human biopsy samples. In thymus, lymph nodes, skin and bone marrow smear only macrophages and young dendritic cells were stained mannose receptor positive. ${ }^{20}$

The immunohistochemistry ${ }^{20}$ also showed that the Moab were specific for the mannose receptor since they did not bind to cells (lymphocytes, monocytes, granulocytes, Langerhans cells) that probably contain other mannose binding proteins. ${ }^{31-33}$ The Moab also did not bind to cells that express receptors with a configuration similar to the mannose receptor (DEC205 receptor, phospholipase A2 receptor). ${ }^{34-36}$ Using Moab 15-2 in immunohistochemistry, we show for the first time that the cells expressing the mannose receptor in human placenta are the Hofbauer cells. These fetal cells have been shown to express many surface antigens also found on monocytes, macrophages and dendritic cells. ${ }^{37}$ Many functions of the Hofbauer cells have been proposed; among these are antigen presentation and immune and non-immune phagocytosis. ${ }^{38}$ The mannose receptor has been shown to play a role in macrophage phagocytosis ${ }^{39,40}$ and antigen uptake by young dendritic cells. ${ }^{41}$ The presence of the mannose receptor on Hofbauer cells suggests a similar role of the mannose receptor in the abovementioned functions of the fetal cells.

On the basis of competition experiments the epitopes of the Moab were analysed in relation to each other and in relation to the binding site of the mannose-containing ligand t-PA. Two epitope clusters were recognised by our set of Moab. Epitope cluster I was recognised by Moab 14-3, 14-5, and 15-2, while epitope cluster II was recognised by Moab 15-14 and 14-2. The affinities of the five Moab differed considerably, but the affinity of each Moab for the receptor was similar in the different assays (Table 1). The Moab with the highest affinities were 15-2 and 14-5, while Moab 15-14 had the lowest affinity.

The mannose receptor contains eight carbohydrate recognition domains (CRD). ${ }^{3}$ At least three of them (number 4,5 and 7) are required for high affinity binding of multivalent glycoconjugates. ${ }^{4}$ The binding site is however not yet fully delineated. ${ }^{5}$ t-PA contains both one high mannose-type and one or two complex-type oligosaccharide chains. ${ }^{10}$ Our previous studies with synthetic cluster mannosides showed that $t-P A$ binding to the isolated mannose receptor is completely inhibited by the mannosides. The more mannose residues the inhibitor contains the higher the affinity of inhibition. ${ }^{42}$ It is likely that the high mannose-type oligosaccharide of t-PA which has three terminal mannose residues binds to more than one CRD. In this report we showed that t-PA binds to the human mannose receptor and its binding was differently and partially inhibited by the Moab (Fig 4). If the binding sites had been completely identical for the Moab and t-PA the expected inhibition would have been (using the model of competitive inhibition ${ }^{30}$ ) $97 \%$ for Moab $14-3,100 \%$ for Moab $14-5,100 \%$ for Moab $15-2$ and $92 \%$ for Moab $14-2$ at a concentration of $10 \mu \mathrm{g} / \mathrm{ml}$. Epitope cluster I Moab (14-3, 14-5, and 15-2) inhibited the binding of t-PA to the mannose receptor for $60 \%$, indicating that the epitope and the t-PA binding site partially coincide. Epitope cluster II appears to be more distant from the t-PA binding site, since Moab 14-2 inhibited t-PA binding for about $30 \%$. 
Mannose receptor mediated degradation of t-PA by cultured macrophages was inhibited by the Moab in a similar way as t-PA binding to the isolated immobilised mannose receptor. This means that the Moab recognised the receptor not only after isolation and purification, but also in its natural environment on the cell membrane. After incubation of macrophages with labelled Moab we previously obtained a higher signal in flow cytometry at $37^{\circ} \mathrm{C}$ than at $4^{\circ} \mathrm{C}$. This suggests that the Moab are internalised upon binding to the mannose receptor at $37^{\circ} \mathrm{C}$, and that free receptor is recycled to the surface. ${ }^{20}$ An explanation for the stronger inhibitory effect of Moab 14-5 on mannose receptor mediated t-PA degradation (Fig 5) as compared to mannose receptor binding of t-PA (Fig 4) would be that on macrophages the Moab affect the binding of t-PA to the receptor and also interferes with the process of endocytosis and/or degradation at $37^{\circ} \mathrm{C}$.

In this study, we showed that in the presence of $25 \mathrm{mM}$ GST-RAP the $10 \mu \mathrm{g} / \mathrm{ml}$ Moab $14-5$ was able to inhibit $87 \%$ of total t-PA degradation, and in the absence of GST-RAP $44 \%$ of total t-PA degradation. The LRP-mediated t-PA degradation was not affected by Moab 14-5 and the inhibition of the mannose receptor mediated degradation was concentration-dependent. As the inhibition of t-PA degradation by macrophage is representative of the inhibition of in vivo clearance, ${ }^{43}$ we expect that low concentrations of Moab would be able to inhibit t-PA clearance substantially.

In conclusion, this set of monoclonal antibodies may be useful for the elucidation of ligand-mannose receptor interactions in general and for the specific detection of human mannose receptor in tissue extracts (Western blots) or on cell membranes (immunohistochemistry). In particular the antibodies can be used to block mannose receptor mediated uptake and degradation of t-PA by cells and Fab fragments may be useful for inhibiting clearance of t-PA from the circulation and may thereby stimulate the fibrinolytic system. ${ }^{44}$

\section{ACKNOWLEDGEMENTS}

We would like to thank Mr. C.J.M. van Leuven for technical assistance in generating the Moab, and Dr. E. Barbé, A. van Leeuwen and Dr. J. Lindeman (Slotervaart Hospital, Amsterdam) for providing the immunohistochemical results. This study was financially supported by the Netherlands Heart Foundation (grant no. 90.294) 


\section{REFERENCES}

1 Stahl PD. The mannose receptor and other macrophage lectins. Curr Opin Immunol 1992; 4: 49-52.

2 Magnusson S, Berg T. Extremely rapid endocytosis mediated by the mannose receptor of sinusoidal endothelial liver cells. Biochem J 1989; 257: 651-6.

3 Taylor ME, Conary JT, Lennartz MR, Stahl PD, Drickamer $\mathrm{K}$. Primary structure of the mannose receptor contains multiple motifs resembling carbohydrate-recognition domains. J Biol Chem 1990; 265: 12156-62.

4 Taylor ME, Bezouska K, Drickamer K. Contribution to ligand binding by multiple carbohydrate-recognition domains in the macrophage mannose receptor. J Biol Chem 1992; 267: 1719-26.

5 Taylor ME, Drickamer K. Structural requirements for high affinity binding of complex ligands by the macrophage mannose receptor. J Biol Chem 1993; 268: 399-404.

6 Rijken DC, Wijngaards G, Zaal-De Jong M, Welbergen J. Purification and partial characterization of plasminogen activator from human uterine tissue. Biochim Biophys Acta 1979; 580: 140-53.

7 Rijken DC, Collen D. Purification and characterization of the plasminogen activator secreted by human melanoma cells in culture. J Biol Chem 1981; 256: 7035-41.

8 Bachmann F. Fibrinolytic agents. Fibrinolysis 1995; 9, Suppl. 1; 9-15.

9 Collen D. Fibrin-selective thrombolytic therapy for acute myocardial infarction. Circulation 1996; 93: 857-65

10 Spellman MW, Basa LJ, Leonard CK, Chakel JA, O'Connor JV, Wilson S, Van Halbeek H. Carbohydrate structures of human tissue-type plasminogen activator expressed in Chinese hamster ovary cells. J Biol Chem 1989; 264: 14100-11.

11 Otter M, Kuiper J, van Berkel TJC, Rijken DC. Mechanisms of tissue-type plasminogen activator (t-PA) clearance by the liver. Ann NY Acad Sci 1992; 667: 43142.

12 Warshawsky I, Bu G, Schwartz AL. 39-kD protein inhibits tissue-type plasminogen activator clearance in vivo. J Clin Invest 1993; 92: 937-44.

13 Smedsrod B, Einarsson M. Clearance of tissue plasminogen activator by mannose and galactose receptors in the liver. Tromb Haemostas 1990; 63: 60-6.

14 Narita M, Bu G, Herz J, Schwartz AL. Two receptor systems are involved in the plasma clearance of tissuetype plasminogen activator (t-PA) in vivo. $J$ Clin Invest 1995; 96: 1164-8.

15 Noorman F, Braat EAM, Rijken DC. Degradation of tissuetype plasminogen activator by human monocyte derived macrophages is mediated by the mannose receptor and by the low density lipoprotein receptor-related protein. Blood 1995; 86: 3421-7. (Chapter 2 of this thesis)

16 Hasapes JP, Daugherty A, Saffitz JE, Sobel BE. Determinants of the distribution of radiolabeled congeners of tissue-type plasminogen activator and its modification for improved clot imaging. Cor Art Dis 1992; 3: 641-9.
17 Kuiper J, Otter M, Rijken DC, van Berkel TJC. Characterization of the interaction in vivo of tissue-type plasminogen activator with liver cells. J Biol Chem 1988; 263: $18220-4$.

18 Mori K, Kawasaki T, Yamshina I. Isolation and characterization of endogenous ligands for liver mannanbinding protein. Arch Biochem Biophys 1988; 264: 647-56.

19 Brock J, Schulze HA, Neels P, Fischer A, Bremer H, Walzel $H$. Detection of mannose-binding proteins on mouse lymphocytes. Eur J Cell Biol 1991; 54: 90-4.

20 Noorman F, Braat EAM, Barrett-Bergshoeff MM, Barbé E, van Leeuwen A, Lindeman J, Rijken DC. Monoclonal antibodies against the human mannose receptor as a specific marker in flow cytometry and immunohistochemistry for macrophages. J Leukocyte Biol in press. (Chapter 4 of this thesis)

21 Otter M, Barrett-Bergshoeff MM, Rijken DC. Binding of tissue-type plasminogen activator by the mannose receptor. J Biol Chem 1991; 266: 13931-5.

22 Otter M, Zockova P, Kuiper J, van Berkel TJC, BarrettBergshoeff MM, Rijken DC. Isolation and characterization of the mannose receptor from human liver potentially involved in the plasma clearance of tissue-type plasminogen activator. Hepatology 1992; 16: 54-9.

23 Lennartz MR, Wileman TE, Stahl PD. Isolation and characterization of a mannose-specific endocytosis receptor from rabbit alveolar macrophages. Biochem $\mathrm{J}$ 1987; 245: 705-11.

24 Lennartz MR, Cole FS, Shepherd VL, Wileman TE, Stahl $P D$. Isolation and characterization of a mannose-specific endocytosis receptor from human placenta. J Biol Chem 1987; 262: 9942-4.

25 Bos R, Siegel K, Otter M, Nieuwenhuizen W. Production and characterization of a set of monoclonal antibodies against tissue-type plasminogen activator (t-PA). Fibrinolysis 1992; 6: 173-82.

26 Westerwoud RJ. Improved fusion methods IV. Technical aspects. J Immunol Meth 1984; 77: 181-96.

27 Browne MJ, Dodd I, Carey JE, Chapman CG, Robinson $\mathrm{JH}$. Increased yield of human tissue-type plasminogen activator obtained by means of recombinant DNA technology. Thromb Haemostas 1985; 54: 422-4.

28 Kluft C, Van Wezel AL, Van der Velden CAM, Emeis JJ, Verheijen $\mathrm{JH}$, Wijngaards $\mathrm{G}$. Large scale production of extrinsic (tissue-type) plasminogen activator from human melanoma cells. In: Advances in biotechnological processes, vol 2. Mizrahi A, Van Wezel AL, eds. Alan R., Liss Inc, New York USA 1983: pp 97-110.

29 Bos ES, Van der Doelen AA, Van Rooy N, Schuurs AHWM. 3,3',5,5'-Tetramethylbenzidine as an Ames test negative chromogen for horse-radish peroxidase in enzyme immunoassay. J Immunoassay 1981; 2: 187-204.

30 Dixon M, Webb EC. Chapter VIII Enzyme inhibitors. In: Enzymes. second ed. Academic press Inc., New York USA 1964: pp 315-59. 
31 Haltiwanger $\mathrm{H}$, Hill RL. The ligand specificity and tissue localisation of a rat alveolar macrophage lectin. $\mathrm{J}$ Biol Chem 1986; 261: 15696-702.

32 Reis e Sousa C, Stahl PD, Austyn JM. Phagocytosis of antigens by Langerhans cells in vitro. J Exp Med 1993; 178: 509-19.

33 Steinbach F, Thiele B. Phenotypic investigation of mononuclear phagocytes by flow cytometry. J Immunol Meth 1994; 174: 109-22.

34 Jiang W, Swiggard WJ, Heufler C, Peng M, Mirza A, Steinman RM, Nussenzweig MC. The receptor DEC-205 expressed by dendritic cells and thymic epithelial cells is involved in antigen processing. Nature 1995; 375: 151-54.

35 Ishizaki J, Hanasaki K, Higashino K, Kishino J, Kikuchi N, Ohara $\mathrm{O}$, Arita $\mathrm{H}$. Molecular cloning of pancreatic group I phospholipase A2 receptor. J Biol Chem. 1994; 8: 5897 904.

36 Hanasaki K, Arita $\mathrm{H}$. Characterization of a high affinity binding site for pancreatic-type phospholipase A2 in the rat. Its cellular and tissue distribution. J Biol Chem 1992; 9: 6414-20.

37 Goldstein J, Braverman M, Salafia C, Buckley P. The phenotype of human placental macrophages and its variation with gestational age. Am J Pathol 1988; 133: 64859.

38 Jones CJP, Fox $\mathrm{H}$. Ultrastructure of the normal human placenta. Electron Microsc Rev 1991; 4: 129-78.

39 Sallusto F, Cella M, Danieli C, Lanzavecchia A. Dendritic cells use macropinocytosis and the mannose receptor to concentrate macromolecules in the major histocompatibility complex class II compartment: Downregulation by cytokines and bacterial products. J Exp Med 1995; 182, 389-400.

40 Ezekowitz RAB. The mannose receptor and phagocytosis. In: Mononuclear phagocytes: biology of monocytes and macrophages, van Furth $R$, ed. Kluwer Acedemic publishers group, Dordrecht, The Netherlands 1992: pp 208-13.

41 Ofek I, Goldhar J, Keisari Y. Nonopsonic phagocytosis of microorganisms. Annu Rev Microbiol 1995; 49: 239-76.

42 Biessen EAL, Noorman $F$, van Teylingen M, Kuiper $J$, Barrett-Bergshoeff, MM, Rijken DC, Bijsterbosch MK, van Berkel ThJC. Design of cluster mannosides as high affinity ligands for the human mannose receptor. J Biol Chem $1996 ; 271 ; 28024-30$. (Chapter 6 of this thesis)

43 Noorman F, Barrett-Bergshoeff MM, Biessen EAL, van de Bilt E, van Berkel, ThJC, Rijken DC. Cluster mannosides are able to inhibit mannose receptor mediated tissue-type plasminogen activator (t-PA) degradation by rat and human cells. Hepatology, submitted. (Chapter 7 of this thesis)

44 Binder BR. Physiology and pathophysiology of the fibrinolytic system. Fibrinolysis 1995; 9, Suppl. 1: 3-8. 


\section{CHAPTER 4}

Monoclonal antibodies against the human mannose receptor as a specific marker in flow cytometry and immunohistochemistry for macrophages.

\footnotetext{
Femke Noorman, Ellen A.M. Braat, Marrie Barrett-Bergshoeff, Ellis Barbé", Alexander van Leeuwen", Jan Lindeman and Dingeman C. Rijken.
}

Gaubius Laboratory, TNO Prevention and Health, Leiden, The Netherlands

-Department of Pathology, Slotervaart Hospital, Amsterdam, The Netherlands.

Reproduced from

Journal of Leukocyte Biology, 1997, 61:63-72 


\section{SUMMARY}

Recently we developed mouse monoclonal antibodies (mAb) against the isolated human 175-kDa mannose receptor. In the present study we tested whether these mAb are suitable for the detection of the mannose receptor on cultured macrophages using flow cytometry and on cells in human tissues using immunohistochemistry.

Human monocytes did not react with the mAb in flow cytometry. Mannose receptor expression became detectable on monocytes cultured for 3 days (macrophages), and was maximal from 4 days onward. The mannose receptor was up-regulated on dexamethasone-treated (immunosuppressed) macrophages, and down-regulated on lipopolysaccharide-treated (activated) macrophages.

Immunohistochemically the staining pattern of our mAb was compared with the marker of monocytes/macrophages KP1. In a bone marrow smear, only macrophages were stained with our mAb, whereas all myeloid cells were stained with KP1. In the thymus and lymph node, mannose receptorpositive branched cells (macrophages and dendritic cells) were detected in connective tissue, thymus cortex (not medulla), and in the T cell area (not the B cell area) of lymph nodes, whereas KP1 stained branched cells in all areas. It was concluded that the mAb are useful tools in flow cytometry and immunohistochemistry for the specific detection of cells expressing mannose receptor.

\section{INTRODUCTION}

The mannose receptor is known to be expressed on macrophages ${ }^{1}$ and probably on liver sinus endothelial cells ${ }^{2}$ and airway smooth muscle cells. ${ }^{3}$ It plays a role in the immune system for the complement-independent clearance of pathogenic organisms (such as Candida albicans and Pneumocytis carinii ) that have polymannose structures on their membranes. ${ }^{4}$ It is suggested that the receptor mediates uptake of the intracellular parasites Leishmania donovani, ${ }^{5}$ Tryponosoma cruzi ${ }^{6}$ and Mycobacterium tuberculosis ${ }^{7}$ by macrophages. Recently it has been suggested that the mannose receptor is involved in the uptake of antigen by human monocyte-derived immature dendritic cells. ${ }^{8}$ Furthermore the receptor mediates uptake and degradation of high mannose-type oligosaccharide containing glycoproteins such as lysosomal enzymes ${ }^{9}$ and tissue-type plasminogen activator (t-PA). ${ }^{10,11}$ Blocking the mannose receptor or increasing its expression on macrophages results in, respectively, increased ${ }^{12}$ and decreased extracellular lysosomal enzyme concentrations in vitro. ${ }^{13}$

The expression of the receptor is highly regulated and correlates with the functional state of the monocyte/macrophage. Monocytes do not express mannose receptors and resting macrophages express higher levels than activated macrophages. ${ }^{11,14,15}$ Monocytes and granulocytes are derived from the same myeloid progenitors in the bone marrow. Commonly used specific markers for human macrophages are also expressed on monocytes (CD14, CD11c, CD68) or on granulocytes (CD11b, CD11C, CD68, CD16). Specific and quantitative measurement of mannose receptor expression might therefore be a good tool for detecting macrophages and for discriminating between various differentiation and activation stages of the macrophage. Mannose receptor expression is frequently assessed by measuring the uptake or binding of receptor ligands. However, the ligand spectrum of the mannose receptor is similar to the ligand spectrum of some other non-macrophage-specific mannose binding proteins which may be present in other cells such as lymphocytes. ${ }^{16}$ Binding of labeled mannose receptor ligands to a cell does not prove that the cell is one of the above-mentioned cells 
expressing mannose receptor. It has been shown that monocytes and granulocytes are able to bind mannose-BSA, ${ }^{17}$ whereas there is no evidence for the presence of the mannose receptor on these cells. ${ }^{1}$

Recently we developed specific monoclonal antibodies ( $\mathrm{mAb}$ ) against the isolated human mannose receptor, which inhibited $t-P A$ binding to the mannose receptor. ${ }^{18}$ To our knowledge no mAb against the mannose receptor have been shown to be effective for the detection of human cells expressing mannose receptor. In this study we tested the possibility of using our mAb as a marker for the human macrophage differentiation and activation state in flow cytometry and as a marker for cells expressing mannose receptor in human tissue using immunohistochemistry. We cultured human monocytes in suspension under varying conditions and evaluated mAb binding to the cells by use of flow cytometry. Furthermore we used the mAb in immunohistochemistry on cryostat sections of human tissue and compared the staining patterns with the currently most widely used human macrophage marker KP1, which recognizes the CD68 antigen. ${ }^{19,20}$

\title{
MATERIALS AND METHODS
}

\begin{abstract}
Materials
Human $\mathrm{AB}^{+}$serum, and thrombocyte-poor pooled buffy coats from healthy donor blood (from six donors with the same blood type combined), were obtained from the Red Cross Blood Bank (The Hague and Leiden, The Netherlands). Lymphoprep ${ }^{T M}$ (Nycomed Pharma AS, Oslo, Norway) with a density of $1.077 \mathrm{~g} / \mathrm{mL}$ was used for density gradient centrifugation. Heparin (Leo Pharmaceutical Products, Ballerup, Denmark), bovine serum albumin (BSA) fraction V (Sigma Chemical Co., St.Louis MO), cell culture medium M199 (Flow Laboratories, Irvine, UK), penicillin/streptomycin (Boehringer Mannheim, Mannheim, Germany), and sterile buffers were used to isolate and culture the cells. They were cultured in Teflon beakers (Savillex Corp., Minnetonka, MN) to prevent adhesion of the monocytes. ${ }^{21}$ Biotin-N-hydroxysuccinimide ester (NHS-Biotin) was supplied by Zymed Laboratories Inc. (South San Francisco, CA). Fluorescein isothiocyanate (FITC), FITC or Phycoerythrin (PE)-labeled mAb against the human monocyte/macrophage CD14 antigen (anti-CD14-FITC, anti-CD14-PE), FITC-, or PE-labeled control immunoglobuline $\mathrm{G}_{1}$ (IgG, ), and streptavidin-PE conjugate were obtained from Becton Dickinson Immunocytometry Systems (San Jose, CA). FITC labeled mAb against the human monocyte/macrophage/ granulocyte CD11c antigen (anti-CD11c-FITC), mouse serum, propidium iodide (PI), dexamethasone (DEX) and lipopolysaccharide (LPS) extracted from Escherichia coli 0111:B4 were purchased from Sigma. Mouse mAb of the IgG, isotype (mAb 15-2, 14-5, 14-3, and 14-2) developed against the human placenta mannose receptor ${ }^{18}$ were labeled and used for flow cytometry. For immunohistochemical studies rabbit-anti-mouse-alkaline phosphatase and KP1 (mouse monoclonal anti-CD68 isotype IgG1, from Dako AS, Glostrup, Denmark) were used on cryostat sections of human tissue.
\end{abstract}

\section{Western blotting of the mannose receptor.}

The $175-\mathrm{kDa}$ mannose receptor was isolated and purified from human placenta on a mannosylated-albumin-Sepharose column, essentially as described earlier. ${ }^{22}$ Purified mannose receptor was run on $6 \%$ sodium dodecyl sulfate (SDS) polyacrylamide gels under nonreducing conditions. After electrophoresis the gels were blotted overnight at room temperature at $150 \mathrm{~mA}$ on nitrocellulose paper in $50 \mathrm{mM}$ borate buffer, $\mathrm{pH} 8.0$, containing $10 \%$ methanol. Blots were incubated for $2 \mathrm{~h}$ with buffer (20 mM Tris. $\mathrm{HCl}, \mathrm{pH} 7.4$, $150 \mathrm{mM} \mathrm{NaCl}, 5 \mathrm{mM}$ ethylenediaminetetraacetate, $0.5 \%$ Tween $80,1 \mathrm{mg} / \mathrm{mL} \mathrm{BSA}$ ). The blotting paper was then incubated for $2 \mathrm{~h}$ with $\mathrm{mAb}$, and subsequently stained with rabbit-anti-mouse polyclonal IgG peroxidase (Nordic, Tilburg, The Netherlands) and BM blue (Boehringer-Mannheim).

\section{Labeling of anti-mannose receptor mAb.}

For biotinylation $1.31 \mathrm{mg} / \mathrm{mL} \mathrm{mAb} 15-2$ was dialyzed against $0.1 \mathrm{M} \mathrm{NaHCO}_{3}, \mathrm{pH} 8.5$, and incubated with $27.2 \mu \mathrm{g} / \mathrm{mL} \mathrm{NHS-biotin} \mathrm{at}$ room temperature for $3 \mathrm{~h}$ and dialyzed at $4^{\circ} \mathrm{C}$ against $20 \mathrm{mM}$ Tris. $\mathrm{HCl}, \mathrm{pH} 7.4$, containing $150 \mathrm{mM} \mathrm{NaCl}, 5 \mathrm{mM} \mathrm{CaCl}$, and $0.01 \%$ ( $v^{\prime} \mathrm{V}$ ) Tween 80. A whole set of anti-mannose receptor mAb (mAb 15-2, 14-5, 14-3, and 14-2) was labeled with FITC. Approximately $1.5 \mathrm{mg} \mathrm{mAb}$ in $1 \mathrm{ml} 0.1 \mathrm{M} \mathrm{Na}_{2} \mathrm{CO}_{3}, \mathrm{pH} 9.0$, was incubated with $25 \mu \mathrm{g} \mathrm{FITC}$ for $80 \mathrm{~min}$ at room temperature in the dark. The unbound dye was separated from the conjugate by gel filtration on a Sephadex G-25 (medium) column. The efficiency of labeling was monitored by estimation of the ratio of fluorescein to protein by calculating the ratio of absorbance at $495 \mathrm{~nm} / 280 \mathrm{~nm}$. FITC-labeled mAb with an absorbance ratio between 0.3 and 1 were used for flow cytometry. 
Monocyte isolation and cultivation.

Monocytes were isolated from pooled human buffy coats as described earlier. ${ }^{11}$ Pooled buffy coat (100 ml) was diluted with $180 \mathrm{ml}$

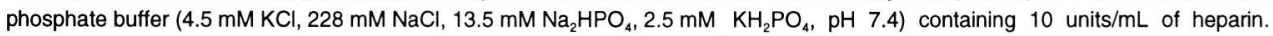
Portions of $35 \mathrm{ml}$ suspension were underlayered with $14 \mathrm{~mL}$ Lymphoprep ${ }^{\mathrm{TM}}$. After 30 min centrifugation at $800 \mathrm{~g}$, the interface was collected and washed $(250 \mathrm{~g}, 10 \mathrm{~min}$ ) twice with phosphate-buffered saline (PBS: $2.7 \mathrm{mmol} / \mathrm{L} \mathrm{KCl}, 137 \mathrm{mmol} / \mathrm{L} \mathrm{NaCl}, 8.1 \mathrm{mmol} / \mathrm{L}$ $\mathrm{Na}_{2} \mathrm{HPO}_{4}, 1.46 \mathrm{mmol} / \mathrm{KH}_{2} \mathrm{PO}_{4}, \mathrm{pH} 7.4$ ) containing $1 \mathrm{mg} / \mathrm{mL}$ BSA. Routinely 1 to $2 \times 10^{9}$ cells were obtained. This cell suspension was further purified using countercurrent flow centrifugation (elutriation). ${ }^{11}$ Elutriation-purified monocytes (approximately 1 to $2 \times 10^{8}$ cells, $85 \% \mathrm{CD} 4^{+}$cells) were washed with PBS and resuspended in culture medium (M199 containing $10 \mathrm{mg} / \mathrm{mL}$ glutamine, 50 UimL penicillin, $50 \mu \mathrm{g} / \mathrm{mL}$ streptomycin, $10 \%(\mathrm{v} / \mathrm{v})$ inactivated human $\mathrm{AB}{ }^{+}$serum). Cells were cultured in suspension at a concentration of $2 \times 10^{6}$ cells $/ \mathrm{mL}$ in Teflon beakers. Every 3 days the medium was refreshed.

\section{Flow cytometric detection of the macrophage mannose receptor.}

The cultured cells were washed with ice-cold binding buffer $(50 \mathrm{mM}$ Tris. $\mathrm{HCl}, \mathrm{pH} 7.4,100 \mathrm{mM} \mathrm{NaCl}, 2.5 \mathrm{mM} \mathrm{CaCl}, 10 \mathrm{mg} / \mathrm{mL}$ $B S A)$. After resuspending the cells in binding buffer the cells were incubated with biotinylated $\mathrm{mAb}$ and $0.5 \mathrm{mg} / \mathrm{mL}$ purified human $\operatorname{IgG}$ (purified from human serum by use of protein A-sepharose) for $2 \mathrm{~h}$ at $4^{\circ} \mathrm{C}\left(5 \times 10^{5}\right.$ cells/100 $\left.\mu \mathrm{L}\right)$. Cells were washed twice with binding buffer and incubated for $30 \mathrm{~min}$ at $4^{\circ} \mathrm{C}$ with streptavidin-PE. In some experiments the cells were double stained by coincubating with anti-CD14-FITC or anti-CD11C-FITC. After washing twice in binding buffer, cell scatter and fluorescence were measured with a FACScan (fluorescence-activated cell scanner) flow cytometer, using the program FACScan research software version 2.1 (Becton Dickinson Immunochemistry Systems, San Jose, CA). For studies with FITC-labeled mAb the cells were washed with ice cold PBS containing $1 \mathrm{mg} / \mathrm{mL}$ BSA and incubated for $30 \mathrm{~min}$ at $4{ }^{\circ} \mathrm{C}$ with FITC-labeled $\mathrm{mAb}$ in PBS containing $1 \mathrm{mg} / \mathrm{mL}$ BSA and $10 \%(\mathrm{~V} / \mathrm{V})$ mouse serum $\left(5 \times 10^{5}\right.$ cells $\left./ 100 \mu \mathrm{L}\right)$. The cells were washed twice with PBS containing $1 \mathrm{mg} / \mathrm{mL}$ BSA, and resuspended in PBS containing $1 \mathrm{mg} / \mathrm{mL}$ BSA and $25 \mu \mathrm{g} / \mathrm{mL}$ propidium iodide at $4^{\circ} \mathrm{C}$. Cell scatter and fluorescence were measured using the FACScan flow cytometer. In some studies the same procedure was followed, except that the cells were incubated at $37^{\circ} \mathrm{C}$ with FITC-labeled mAb.

\section{Analysis of Data}

Cell-bound fluorescence was measured using the FACScan flow cytometer, which was calibrated regularly with beads with known scatter and fluorescence intensity. A total of 5000 cells per sample was measured. Labels were excited by a $15 \mathrm{~mW}$ Argon laser that produces blue light of $488 \mathrm{~nm}$ wavelength. The following five parameters were registered per cell: forward scatter (FSC), reflecting cell size; side scatter (SSC), reflecting the amount of particles inside the cell that scatter the incoming light; green (FITC) fluorescence (FL1); orange (PE) fluorescence (FL2); and red fluorescence (FL3). Spectral overlap between the green, orange and red fluorescence was electronically compensated. PI only penetrates through membranes of dead cells and stains their DNA. Dead cells, cell debris, and lymphocytes had a different FSC and SSC from living monocytes or macrophages. Only cells with an FSC and an SSC of living monocytes/ macrophages ( $>95 \%$ CD14 cells, $<5 \% \mathrm{PI}^{+}$cells) were used for the quantitative measurement of the fluoresence caused by bound anti-mannose receptor mAb. Values of fluorescence were obtained as channel numbers and the mean channel number of the (selected) cell population was calculated. For the discrimination of populations of cells the fluorescence was measured in a log mode with each channel number reflecting a log arbitrary fluorescence unit. When measurements were performed in a linear mode, the channel numbers reflected arbitrary fluorescence units. Because log amplifiers are not perfectly logarithmic and the number of channels may differ per decade ${ }^{23}$ a calibration curve was made of the mean channel number of cells labeled with different amounts of anti-CD14-FITC or anti-CD14-PE measured in the linear mode and in the logarithmic mode. When measurements were performed in the log mode, this calibration curve was used to calculate the mean arbitrary fluorescence units from the mean channel number .

\section{Immunohistochemistry.}

Tissues were obtained from biopsy samples (Department of Pathology, Slotervaart Hospital, Amsterdam) and snap frozen in liquid nitrogen. A modification of the immuno alkaline-phosphate (AP) method described by Li et al. ${ }^{24}$ was used. Sections of $8 \mu \mathrm{m}$ thickness were cut on a Reichert-Jung 2800 frigocut cryostat, transferred to poly-L-lysine coated microscope slides, air dried, and fixed in acetone (10 $\mathrm{min}$ at room temperature), rinsed in PBS, and incubated with primary antibody for $30 \mathrm{~min}$ at room temperature. After rinsing in PBS (5 min), the sections were incubated with an alkaline-phosphatase-conjugated secondary antibody for $15 \mathrm{~min}$ at room temperature, rinsed with PBS (5 min), and incubated for $30 \mathrm{~min}$ at room temperạture in the dark with naphtol-AS-MX-phosphate (Sigma) and New Fuchsine (Chroma Gezellschaft, Köngen, BRD) as a coupling salt to develop a red reaction product. Finally the sections were rinsed with aqua dest, counterstained with Mayers hematoxilin, and mounted in DePeX mounting medium (BDH, Poole, UK). Serial dilutions of mAb 14-5 and 15-2 in PBS were tested for reactivity and finally used at $1 \mu \mathrm{g} / \mathrm{mL}$. In control sections no primary antibody was used. The identity of the cells was judged on the basis of their morphology and location in the tissue. The mAb were also tested on paraffin-embedded tissue sections. Only mAb 15-2 showed some reactivity with these sections but the staining was granule-like and not clearly associated with the cells, therefore only cryostat sections were used in this study. 


\section{RESULTS}

\section{Western blot}

To show that our mAb recognized the 175-kDa human mannose receptor we performed a Western blot. As shown in figure 1 the mAb 15-2 and 14-5, and not the control mAb, specifically stained the 175-kDa mannose receptor isolated and purified from human placenta (the antigen we used to immunize mice $\left.{ }^{18}\right)$.

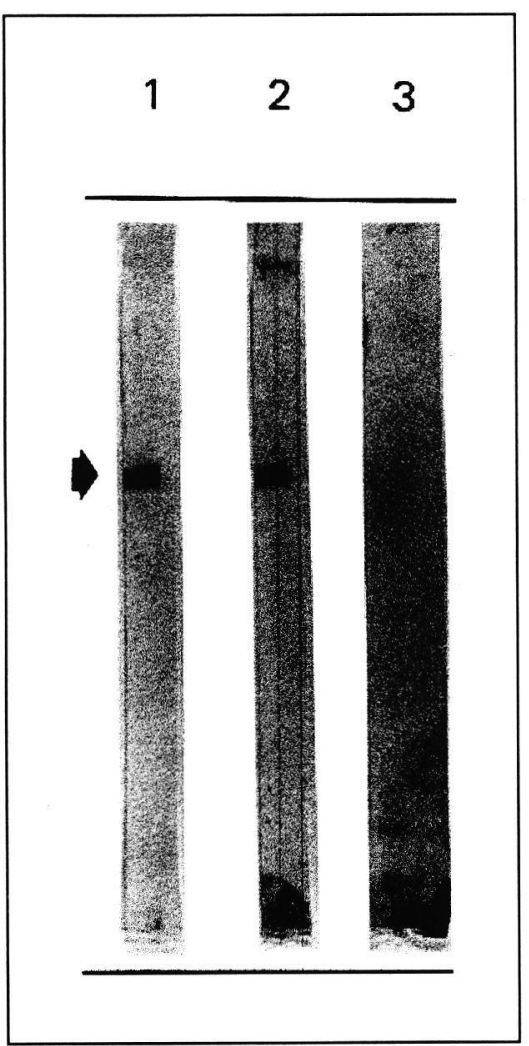

Fig 1 SDS PAGE and Western blotting of purifled mannose receptor.

Lane 1, mAb 14-5; lane 2, mAb 15-2; lane 3, isotypematched control mAb. The arrow indicates the position of the $175 \mathrm{kDa}$ mannose receptor.

\section{Facs analysis of monocyte/macrophage differen- tiation}

Isolated human monocytes $\left(85 \% \mathrm{CD}_{14}{ }^{+}\right)$were cultured in suspension. Cells were stained each day for mannose receptor and $\mathrm{CD} 14$ or $\mathrm{CD} 11 \mathrm{c}$ using, respectively, biotinylated $\mathrm{mAb}$ 15-2 combined with streptavidine-PE and anti-CD14-FITC or anti-CD11C-FITC. In the presence of $10 \%$ mouse serum or $0.5 \mathrm{mg} / \mathrm{mL} \operatorname{lgG}$ no binding of labeled control $\lg _{1}$ was detectable throughout the experiments. A typical example of the monocyte, lymphocyte, and macrophage staining with anti-CD11c (fluorescence 1) and mAb 15-2 (fluorescence 2) is shown in Fig 2A. The total population of cells consisted of monocytes/macrophages, lymphocytes, and cell debris. Each population was analysed separately using electronic gating. Monocytes/macrophages (gate 1) were distinguished from lymphocytes and cell debris (gate 2) by their size (forward scatter) and amount of internal particles (side scatter). We show the reactivity of the cultured gate 2 cells because they are representative for lymphocyte staining; fresh lymphocytes isolated separately from the pooled buffy coats appeared in the same gate and reacted in the same way as cultured gate 2 cells to the mAb tested below (not shown). More than $95 \%$ of the gate 1 cells were stained with anti-CD14 or anti-CD11c on each day studied. Gate 1 macrophages (cultured 4 days), but not monocytes (cultured 1 day), were stained with mAb 15-2. No binding of mAb 15-2, anti-CD14, or anti-CD11c to lymphocytes was observed during the whole culture period. The fluorescence caused by mAb binding compared with the blank fluorescence (mainly autofluorescence) is shown in the histograms (Fig 2B). 

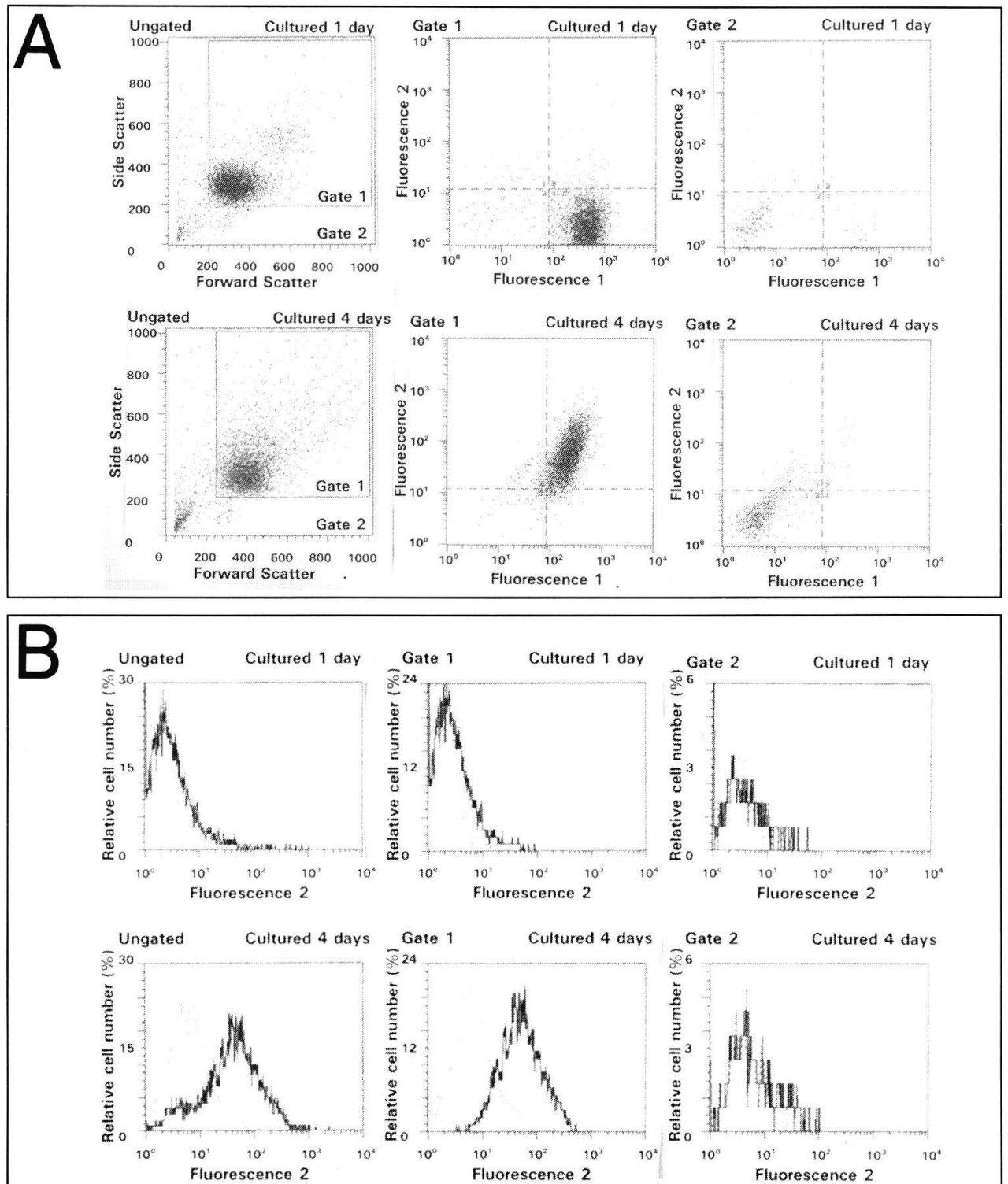

Fig 2 Facs analysis of mAb 15-2 binding to human lymphocytes, monocytes and macrophages.

Monocytes were cultured for 1 or 4 days and incubated at $4^{\circ} \mathrm{C}$ with or without $10 \mu \mathrm{g} / \mathrm{mL}$ biotinylated mAb $15-2$ followed by an incubation with streptavidin-PE (fluorescence 2) and anti-CD11C-FITC (fluorescence 1). Gates were set on populations based on the forward scatter (cell size) and side scatter (internal cell particles). Gate 1 contained monocytes/macrophages, whereas gate 2 contained lymphocytes and cell debris. Total and scatter-gated dot plots are shown, with the dotted cross indicating the limits of the blank fluorescence (A). Overlay histograms (relative cell number versus log fluorescence 2) of cells incubated with mAb 15-2 plus streptavidin-PE and anti CD11C-FITC (line) and control cells incubated with streptavidin-PE and anti-CD11C-FITC (dotted line) of the total and scatter-gated cell populations are shown in B. 
The mean fluorescence of gate 1 cells was calculated for each day during culture (Fig 3 ). The mannose receptor was not detectable on 1- to 2- day cultured monocytes, and became detectable after culturing the monocytes for 3 days. Binding of the mAb was concentration dependent, and expression of the mannose receptor remained stable from day 4 onward. Compared with these results obtained with biotinylated mAb 15-2, similar results were obtained with FITC-labeled mAb 15-2, 14-5, and 14-3, which recognize the same epitope, and with $m A b$ 14-2, which recognizes a different epitope on the mannose receptor. ${ }^{18}$ The lymphocytes (gate 2 or isolated from buffy coats by use of elutriation) did not react with any of these mAb (not shown). The specificity of binding of mAb 14-5, 14-3, and 14-2 was demonstrated on 6- to 9-day-old cells. Fig 4 shows that the unlabeled $\mathrm{mAb}$ were able to compete for the binding of the corresponding FITC-labeled mAb. No inhibition was observed with $600 \mu \mathrm{g} / \mathrm{mL}$ control $\operatorname{lgG}_{1}$.

When living macrophages were incubated with FITC-labeled mAb $15-2$ at $37^{\circ} \mathrm{C}$ a higher signal was obtained than at $4^{\circ} \mathrm{C}$ (Fig $5 \mathrm{~A}$ ). Fig $5 \mathrm{~B}$ shows that the binding at $37^{\circ} \mathrm{C}$ and at $4^{\circ} \mathrm{C}$ of labeled $\mathrm{mAb} 15-2$ was specific because it was inhibited with excess unlabeled $m A b$ 15-2. Because the inhibition with cold ligand occurred at similar concentrations at both temperatures, the increased signal appeared not to be due to increased affinity for the receptor at $37^{\circ} \mathrm{C}$. The higher signal at $37^{\circ} \mathrm{C}$ suggests accumulation of labeled mAb inside the cell, which is compatible with internalisation of the mAb-receptor complex, release of the mAb inside the cell, and recycling of the receptor. ${ }^{25}$

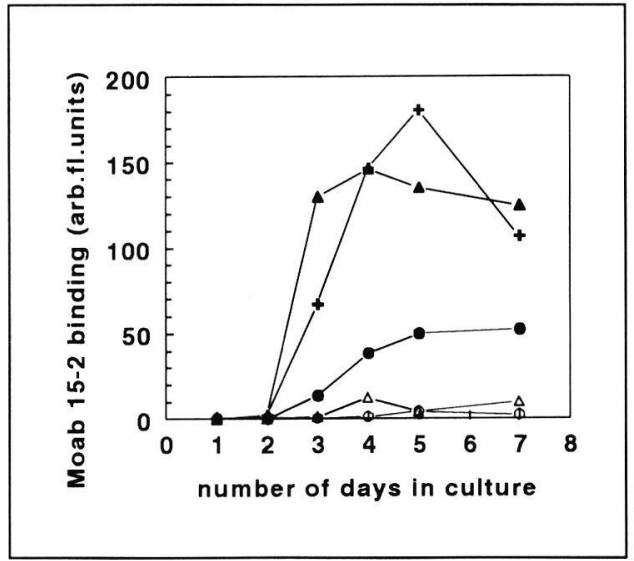

Fig 3 Binding at $4^{\circ} \mathrm{C}$ of different concentrations of biotinylated mAb 15-2 to cells cultured for $1-7$ days. Binding was detected by use of streptavidin-PE and fluorescence was measured in a log mode. mAb binding to scatter gate 1 cells was expressed as mean arbitrary fluorescence units (calculated using a calibration curve; see Materials and Methods). Concentration mAb 15-2: $10 \mu \mathrm{g} / \mathrm{mL}$ $(\Delta), 5 \mu \mathrm{g} / \mathrm{mL}(+), 1 \mu \mathrm{g} / \mathrm{mL}(\bullet), 0.1 \mu \mathrm{g} / \mathrm{mL}(\Delta)$, blank (O).

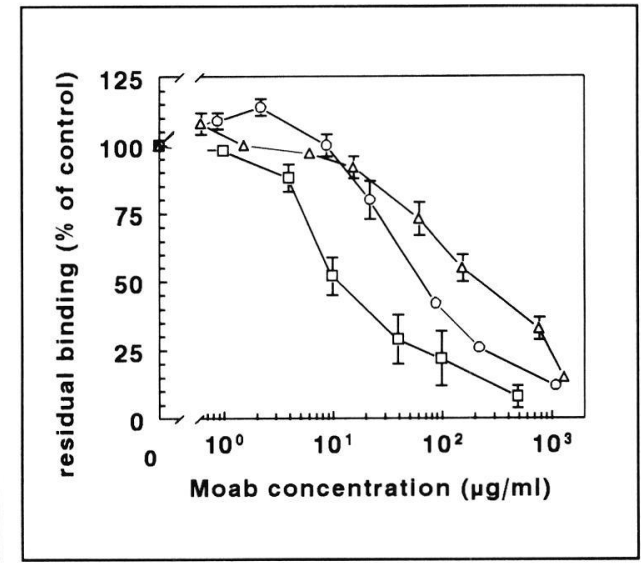

Fig 4 Binding at $4^{\circ} \mathrm{C}$ of different mAb to monocytes/ macrophages.

Monocytes cultured for 6-9 days were incubated at $4^{\circ} \mathrm{C}$ with FITC-labeled anti-mannose receptor mAb 14-5, 14-3, or 14-2 (25-50 $\mu \mathrm{g} / \mathrm{mL})$ and different concentrations of the corresponding unlabeled mAb. Residual mAb binding to the scatter gate 1 cells was measured in a linear mode, and expressed as a percentage of control (mean \pm standard error of the mean, $n=3$ ). Symbols are as follows: mAb 14-5 ( $\square$ ), mAb 14-3 (O), and mAb 14-2 ( $\triangle)$. 


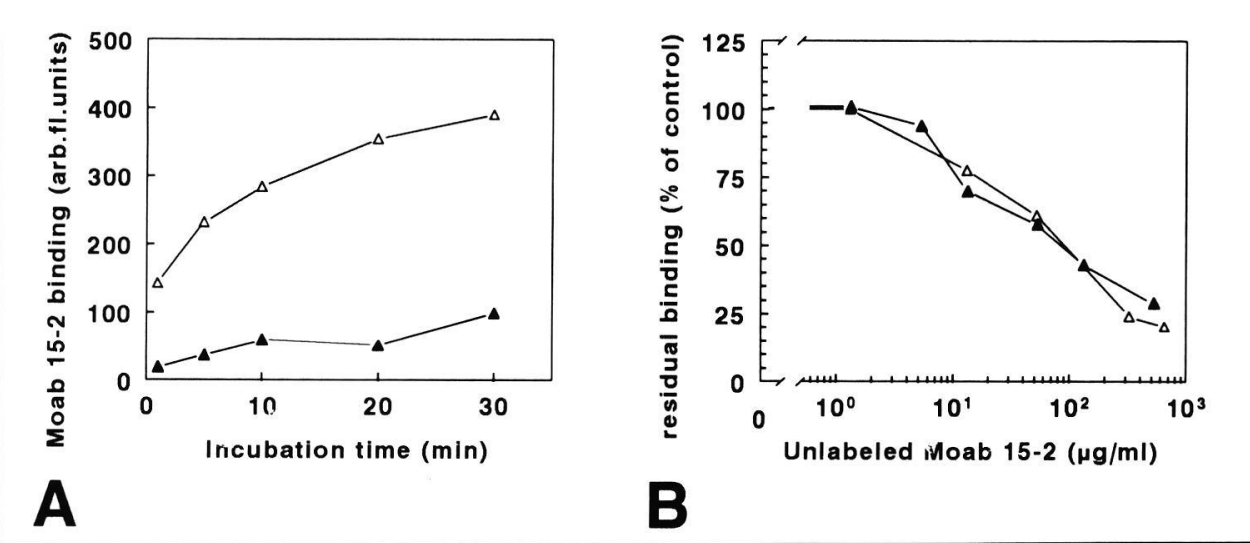

Fig 5 Temperature dependency and specificity of the interaction between mAb 15-2 and monocytes/macrophages cultured for 5 - 7 days.

Cells were incubated with $35 \mu \mathrm{g} / \mathrm{mL}$ FITC-mAb $15-2$ and $0.5 \mathrm{mg} / \mathrm{mL}$ purified human IgG in PBS containing $1 \mathrm{mg} / \mathrm{mL}$ BSA. FITCmAb 15-2 binding to scatter gate 1 cells was measured in a log mode and expressed as mean arbitrary fluorescence units (calculated by use of a calibration curve, see Materials and Methods). Incubations were performed at $4^{\circ} \mathrm{C}(\Delta)$ or at $37^{\circ} \mathrm{C}(\Delta)$ for various time periods $(\mathrm{A})$, and for $30 \mathrm{~min}$ at $4^{\circ} \mathrm{C}(\Delta)$ or at $37^{\circ} \mathrm{C}(\Delta)$ in the presence of increasing concentrations of unlabeled $\mathrm{mAb} 15-2(B)$

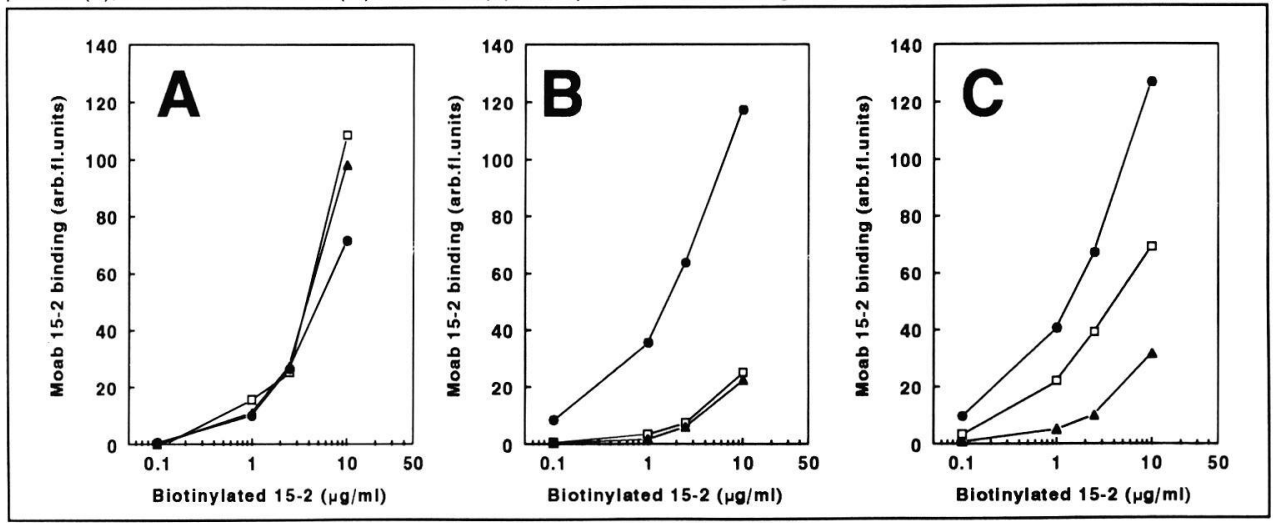

Fig 6 Effect of DEX or LPS on biotinylated mAb 15-2 binding to monocytes cultured for 3 or 4 days.

Binding was detected by use of streptavidin-PE and fluorescence was measured in a log mode. mAb binding to scatter gate 1 cells was expressed as mean arbitrary fluorescence units (calculated with the use of a calibration curve, see Materials and Methods). Cultured monocytes were treated with or without $0.1 \mu \mathrm{g} / \mathrm{mL}$ DEX or LPS on day 3 , and measured at day 4 (A). Monocytes were continuously treated from day 0 onward and measured at day $3(B)$ and on day 4 (C). Symbols are as follows: non-treated ( $\square$ ), DEXtreated $(\bullet)$, LPS-treated $(\mathbf{\Delta})$.

\section{Facs analysis of activated/immunosuppressed macrophages}

To assess whether it was possible to detect different levels of mannose receptor expression by flow cytometry using the anti-mannose receptor $\mathrm{mAb}$, we treated the monocytes/macrophages with DEX or LPS in order to up- or down-regulate the receptor and measured scatter, autofluorescence, anti-CD11C, anti-CD14, and mAb 15-2 binding. Cells were treated with DEX or LPS on day 3 and after $24 \mathrm{~h} \mathrm{mAb} 15-$ 2 binding was measured (Fig 6A). No differences were observed from non-treated cells. 
Then, from day 0 , monocytes were treated with these agents and binding was measured at day 3 (Fig $6 \mathrm{~B}$ ) and day 4 (Fig 6C). The cells were differently affected by the two agents. Compared to that of nontreated cells the average autofluorescence, forward, and side scatter of the cells was higher and the CD14 expression lower when stimulated 3 or 4 days with DEX, whereas the side scatter was higher and CD11c expressiun was lower when stimulated for 4 days with LPS (not shcivr). mAb ${ }^{1} 5-2$ binding was up-regulatec by 2EX after 3 and 4 days in culture, and down-regulated (nu' up-regulated ine nonstimulated macrophages) by LPS after 4 days in culture. Throughout the experiments the cells expressing mannose receptor displayed a normal fluorescence distribution and no population subsets were distinguished.

\section{Immunohistochemistry}

Table 1 shows a comparison of cell staining with KP1 and cell staining with mAb 15-2. mAb 14-5 was also tested and stained the same cells as mAb 15-2 (not shown). Very different staining patterns of mAb 15-2 and KP1 were observed. In a cytospin of bone marrow cells, the granulocytes, monocytes, and macrophages (all myeloid cells) were stained with KP1, whereas only the macrophages reacted with $\mathrm{mAb}$ 15-2. In the thymus KP1 reacted with branched cells (macrophages and dendritic cells) in every area, with rounded cells (monocytes, granulocytes?) and with the endothelium of small blood vessels in the medulla. mAb 15-2 predominantly stained branched cells in the cortex and only a few branched cells in the medulla. Both mAb reacted with the branched cells lying along the connective tissue septa. In the lymph node KP1 reacted with branched cells in every area, whereas mAb 15-2 predominantly reacted with branched cells in the subcapsular sinus, the T cell area, and the medulla. In the skin, KP1 stained branched cells in the dermis and the Langerhans cells in the epidermis, whereas mAb 15-2 only stained the branched cells in the dermis and not the Langerhans cells in the epidermis. Representative areas of thymus and lymph node stained by KP1 or mAb 15-2 are shown in Fig 7 and 8.

Table 1 : Comparison of cell staining with KP1 or mAb 15-2 in human tissue.

$$
\text { + strong staining, - no staining, } \quad-(+) \text { very few cells stained. }
$$

\begin{tabular}{|c|c|c|c|c|}
\hline TISSUE & AREA & CELL TYPE & KP1 & $15-2$ \\
\hline Bone marrow smear & & $\begin{array}{l}\text { lymphocytes } \\
\text { granulocytes } \\
\text { monocytes } \\
\text { megakaryocytes } \\
\text { macrophages }\end{array}$ & $\begin{array}{l}- \\
+ \\
+ \\
- \\
+\end{array}$ & $\begin{array}{l}- \\
- \\
- \\
+\end{array}$ \\
\hline Thymus & $\begin{array}{l}\text { cortex } \\
\text { connective tissue trabecula } \\
\text { medulla }\end{array}$ & $\begin{array}{l}\text { branched cells }{ }^{a} \\
\text { branched cells } \\
\text { rounded cells } \\
\text { branched cells } \\
\text { endothelium }\end{array}$ & $\begin{array}{l}+ \\
+ \\
+ \\
+ \\
+\end{array}$ & $\begin{array}{l}+ \\
+ \\
- \\
-(+)\end{array}$ \\
\hline Lymph node & $\begin{array}{l}\text { subcapsular sinus } \\
\text { T cell area } \\
\text { B cell area } \\
\text { mantle zone } \\
\text { germinal centre } \\
\text { medulla }\end{array}$ & $\begin{array}{l}\text { branched cells } \\
\text { branched cells } \\
\text { banched cells } \\
\text { branched cells } \\
\text { branched cells }\end{array}$ & $\begin{array}{l}+ \\
+ \\
+ \\
+ \\
+\end{array}$ & $\begin{array}{l}+ \\
+ \\
-\left(\begin{array}{l}+ \\
+ \\
+ \\
+\end{array}\right.\end{array}$ \\
\hline Skin & $\begin{array}{l}\text { epidermis } \\
\text { dermis }\end{array}$ & $\begin{array}{l}\text { Langerhans cells } \\
\text { branched cells }\end{array}$ & + & $\dot{+}+$ \\
\hline
\end{tabular}

${ }^{a}$ The branched cells observed can be macrophages or dendritic cells (called interdigitating cells in the T cell area or follicular dendritic cells in the B cell area). Both celltypes are known to be present in lymphoid and non-lymphoid tissues, and macrophages are morphologically not different from dendritic cells when viewed by light microscopy (see Discussion). 


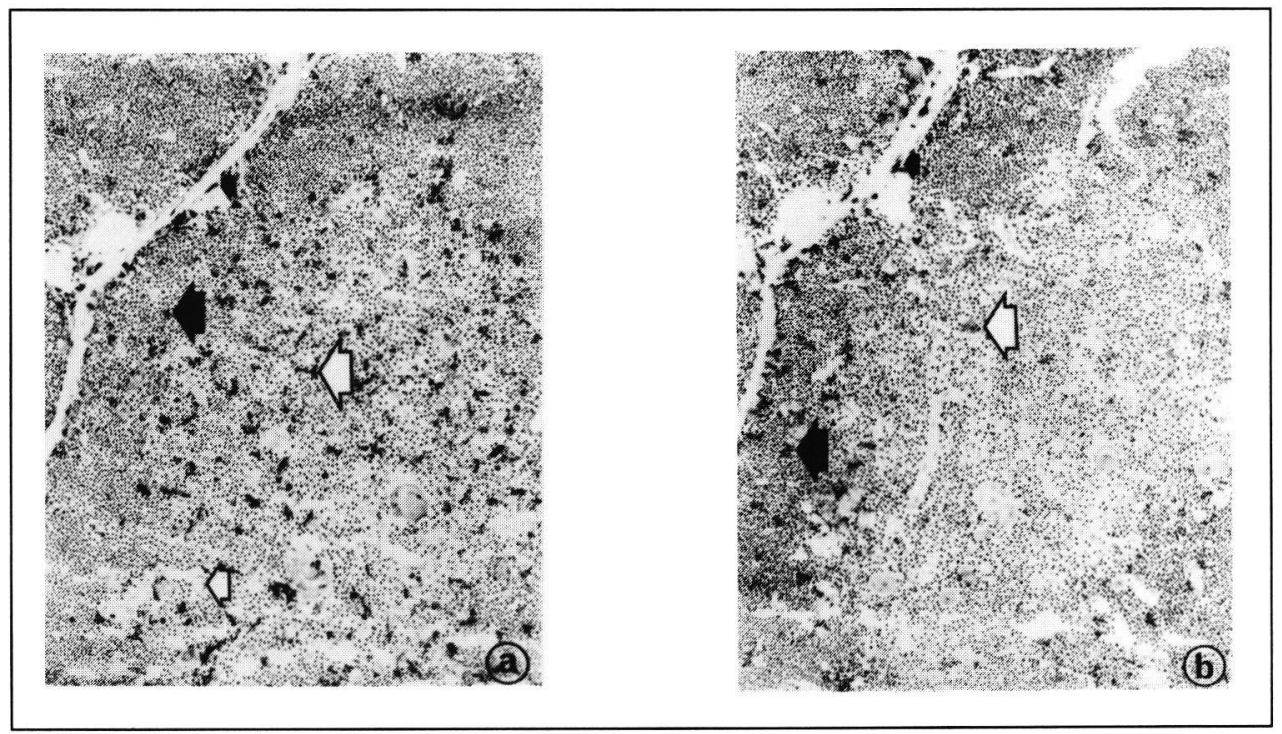

Fig 7 Staining patterns of KP1 (a) and mAb 15-2 (b) in cryostat sections of human thymus. In the middle, the thymus medulla with many KP1 and few mAb 15-2 positive cells is shown (branched cells, large white arrow; endothelium small white arrow). In the periphery the thymus cortex with KP1 and mAb 15-2-positive cells (branched cells, large black arrow) and the connective tissue septa with KP1 and mAb 15-2-positive cells (branched cells, small black arrow) are shown.

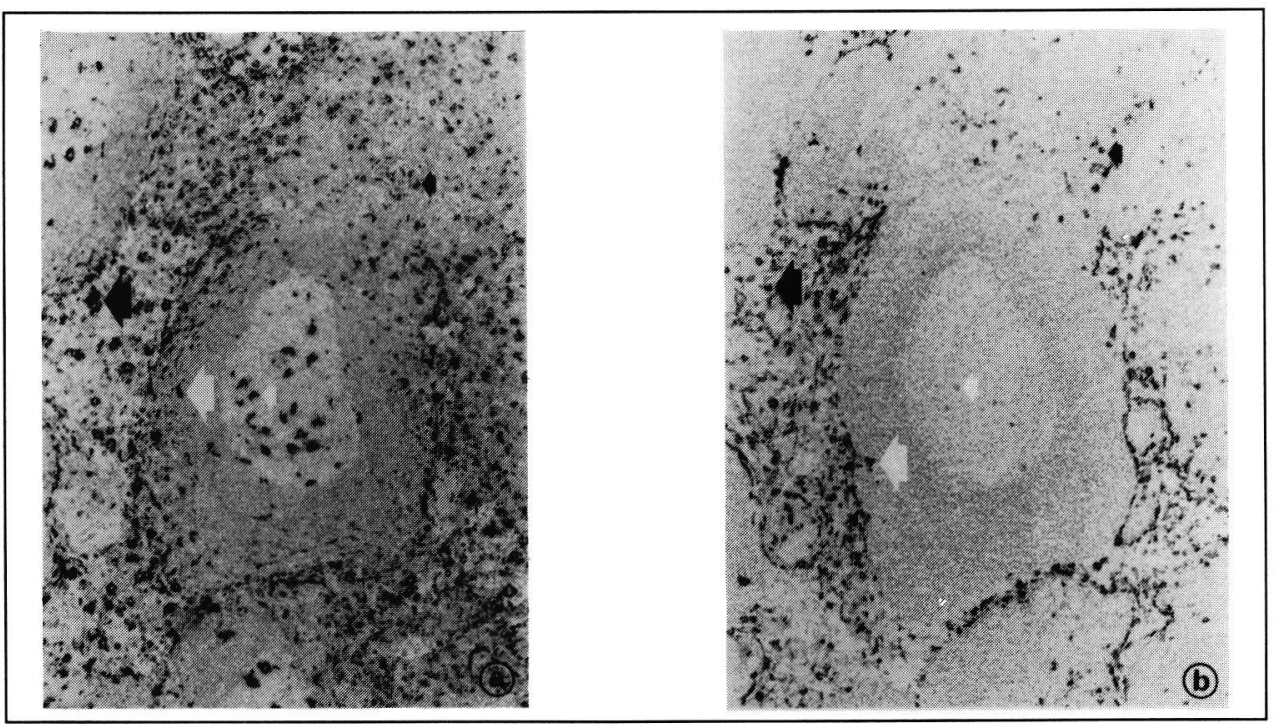

Fig 8 Staining patterns of KP1 (a) and mAb 15-2 (b) in cryostat sections of human lymph node. In the middle the B cell area, follicle with germinal centre and mantle zone, containing many KP1 and few mAb 15-2-positive cells is shown (branched cells, germinal centre, small white arrow; mantle zone, large white arrow). In the periphery the T cell area with KP1 and mAb 15-2 positive cells (branched cells, small black arrow) and the medulla with KP1 and mAb 15-2 positive cells (branched cells, large black arrow) are shown 


\section{DISCUSSION}

In this study we describe the use of mAbs against the human mannose receptor to specifically detect human cells expressing mannose receptor in flow cytometry and immunohistochemistry

Human monocytes differentiate to macrophages depending on the culture conditions within a few days. ${ }^{21,26}$ Mannose receptor-mediated binding and degradation of ligands is observed after culturing the monocytes for a few days. ${ }^{4,11}$ Our mAbs, which were able to detect the 175-kDa mannose receptor isolated from human placenta in Western blots, proved to be suitable for specific and quantitative detection of cells expressing mannose receptor using flow cytometry. Using the mAb we showed that the mannose receptor is absent on lymphocytes and monocytes and is up-regulated on monocytes during differentiation to macrophages.

Binding of the mAb was concentration dependent, and was inhibited by the corresponding unlabeled $\mathrm{mAb}$. At $37^{\circ} \mathrm{C} \mathrm{mAb} 15-2$ possibly was internalized and the free receptor was recycled because, compared with the binding at $4^{\circ} \mathrm{C}$, higher levels of fluorescence were observed without any change in the mAb affinity for the receptor. This is consistent with other studies which state that approximately $80 \%$ of the macrophage mannose receptor is not expressed on the cell membrane due to the internalization and recycling of the receptor. ${ }^{25}$

Down-regulation by LPS and up-regulation by DEX of the macrophage mannose receptor activity have previously been demonstrated. ${ }^{11,15,27-29}$ LPS down-regulates and DEX up-regulates macrophage mannose receptor-mediated t-PA degradation. ${ }^{11}$ We showed that it was possible with mAb 15-2 to discriminate between non-stimulated, LPS stimulated and DEX stimulated macrophages. Downregulation by LPS of both mannose receptor and CD11c was observed on cells cultured for 4 days. LPS irreversibly inactivates the receptor without affecting total receptor biosynthesis by an unknown mechanism. ${ }^{27}$ mAb 15-2 recognizes a site close to the t-PA binding site because it is able to inhibit t-PA binding to the mannose receptor. ${ }^{18}$ The LPS mediated down-regulation of mAb 15-2 binding observed does not necessarily mean that the whole receptor was down-regulated; it could have been caused by binding site masking or destruction. The correlation of decreased mAb 15-2 binding with decreased receptor function suggests that $\mathrm{mAb} 15-2$ binding in flow cytometry reflects functional mannose receptor expression.

DEX up-regulates the mannose receptor by up-regulation of receptor mRNA followed by receptor synthesis ${ }^{28}$ as does interleukin-4.9.$^{29}$ Granulocyte-monocyte colony-stimulating factor and interleukin-4 treatment of monocytes results in differentiation to cells with up-regulated mannose receptors and many characteristics of immature dendritic cells. ${ }^{8,30}$ Macropinocytosis and mannose receptors are used by these cells for the efficient capture of antigens. ${ }^{8}$ In our experiments mannose receptor up-regulation by DEX was observed on the third day in culture. It may be possible that the higher expression of mannose receptor on our DEX-treated monocytes was an indication of differentiation of the monocytes to cells with characteristics of immature dendritic cells. 
Immunohistochemistry showed that our mAbs (mAb 15-2 and 14-5) did not recognize cells that are known to contain other mannose binding proteins with a similar ligand spectrum, or receptors with a similar configuration to the mannose receptor. mAb 15-2 did not stain lymphocytes that have mannose binding protein ${ }^{16}$ and no lymphocytes or vascular endothelial cells that express pancreatic group I phospholipase A2 receptor ${ }^{31}$ (a receptor analogous to the mannose receptor ${ }^{32}$ ). The mAb did not stain thymic epithelial cells that may express the DEC-205 receptor (a receptor analogous to the mannose receptor ${ }^{33}$ ). Although freshly isolated Langerhans cells are able to internalize mannose-BSA, no 175$\mathrm{kDa}$ receptor is found in Western blots. ${ }^{34}$ We did not find mannose receptor positive Langerhans cells in the epidermis, indicating that a different mannose binding protein mediates the uptake of mannose-BSA. Similarly monocytes and granulocytes, which are able to bind mannose-BSA ${ }^{17}$ and do not contain the 175-kDa mannose receptor, ${ }^{1}$ were not stained with mAb 15-2. KP1, although commonly used as a macrophage marker, also stains other myeloid cells (monocytes, granulocytes) besides macrophages and some endothelial and epithelial cells. ${ }^{20}$ We showed a different staining pattern for KP1 and mAb 15-2.

It has been suggested that the mannose receptor plays a role in the uptake of antigen followed by antigen presentation by dendritic cells, Langerhans cells, and macrophages in vitro. ${ }^{8,34,35}$ We showed that most of the known cells of the dendritic cell family (Langerhans cells, follicular dendritic cells in the B cell areas of the lymph node and the interdigitating dendritic cells in the thymus medulla) did not express the mannose receptor, whereas we did find mannose receptor-positive branched cells in the dermis, lymph node T cell areas, and the thymus cortex. Dendritic cells exist in two stages of maturation. Immature cells are present scattered throughout the body. When they pick up and process antigen they subsequently move to the $T$ cell areas of secondary lymphoid organs. Somewhere during this process (location unknown) they mature; they lose their antigen-capturing capacity and become cells that trigger the naive $\mathrm{T}$ cells recirculating through the $\mathrm{T}$ cell areas. ${ }^{36}$

Monocytes cultured in the presence of granulocyte-monocyte colony-stimulating factor and interleukin-4 become immature dendritic cells that express the $175 \mathrm{kDa}$ mannose receptor while being able to capture antigens, and that down-regulate the mannose receptor when they are stimulated with maturation-inducing agents like tumor necrosis factor $\alpha$ and LPS. ${ }^{8}$ Stimulation of these cells with tumor necrosis factor $\alpha$ results in decreased antigen capture capacity and increased stimulatory capacity in a mixed lymphocyte reaction. ${ }^{30}$ We suggest that the mannose receptor-positive (and KP1 positive) branched cells seen in the tissues represent resident macrophages and immature dendritic cells, and the mannose receptor-negative (and KP1 positive) branched cells represent activated macrophages and mature dendritic cells. Thus our mAb may be useful in combination with other markers to study the process of dendritic cell maturation in human tissues.

Because the mannose receptor is thought to be involved in the non-opsonic degradation of pathological organisms, ${ }^{4}$ and in the internalization of parasites that manage to survive and replicate inside the macrophage, ${ }^{5,6,7}$ our mAbs may offer new insights into the role of the mannose receptor in various diseases.

In conclusion the mannose receptor is a specific marker for different types of macrophages. Our mAb proved to be a useful tool for detecting the $175-\mathrm{kDa}$ mannose receptor in Western blots, for discriminating resting macrophages from immunosuppressed and activated macrophages using flow cytometry, and for detecting cells expressing mannose receptor in cryostat sections of human tissues. 


\section{ACKNOWLEDGEMENT}

We would like to thank Mr. F.J. Tielen for his helpful advice concerning the use of the flow cytometer, and Dr. J.D. Laman for his critical evaluation of this manuscript. This study was financially supported by the Netherlands Heart Foundation (grant no. 90.294).

\section{REFERENCES}

1 Haltiwanger, H., Hill R.L. (1986) The ligand specificity and tissue localisation of a rat alveolar macrophage lectin. J.Biol.Chem. 261, 15696-15702.

2 Magnusson, S., Berg, T. (1993) Endocytosis of ricin by rat liver cells in vivo and in vitro is mainly mediated by mannose receptors on sinusoidal endothelial cells. Biochem.J. 291, 749-755.

3 Lew, B.D., Songu-Mize, E., Pontow, S.E., Stahl, P.D., Rattazzi, M.C. (1994) A mannose receptor mediates mannosyl-rich glycoprotein-induced mitogenesis in bovine airway smooth muscle cells. J.Clin.Invest 94, 1855-1863.

4 Drickamer, K., Taylor, M.E. (1993) Biology of animal lectins. Annu.Rev.Cell.Biol. 9, 237-264.

5 Chakraborty, P., Das, P.K. (1988) Role of mannose/Nacetylglucosamine receptors in blood clearance and cellular attachment of Leishmania donovani. Mol.Biochem. Parasitol. 28, 55-62.

6 Kahn, S., Wleklinski, M., Aruffo, A., Farr, A., Coder, D., Kahn, M. (1995) Trypanosoma cruzi amastigote adhesion to macrophages is facilitated by the mannose receptor. J.Exp.Med. 182, 1243-1258.

7 Schlesinger, L.S., Hull, S.R., Kaufman, T.M. (1994) Binding of the terminal mannosyl units of lipoarabinomannan from a virulent strain of Mycobacterium tuberculosis to human macrophages. J.Immunol. 152, 4070-4079.

8 Sallusto, F., Cella, M., Danieli, C., Lanzavecchia, A. (1995) Dendritic cells use macropinocytosis and the mannose receptor to concentrate macromolecules in the major histocompatibility complex class II compartment: Downregulation by cytokines and bacterial products. J.Exp.Med. 182, 389-400.

9 Stahl, P.D., Somsel Rodman, J., Miller, M.J., Schlesinger, P.H. (1978) Evidence for receptor-mediated binding of glycoproteins, glycoconjugates, and lysosomal glycosidases by alveolar macrophages. Proc.Nat.Acad.Sci.USA 75, 13991403.

10 Otter, M., Kuiper, J., Bos, R., Rijken, D.C., van Berkel, Th.J.C. (1992) Characterization of the interaction both in vitro and in vivo of tissue-type plasminogen activator (t-PA) with rat liver cells. Biochem.J. 284, 545-550.

11 Noorman, F., Braat, E.A.M., Rijken, D.C. (1995) Degradation of tissue-type plasminogen activator by human monocyte derived macrophages is mediated by the mannose receptor and by the low density lipoprotein-related protein. Blood $\mathbf{8 6 ,}$ 3421-3427. Chapter 2 of this thesis.

12 Ohsumi, Y., Lee, Y.C. (1987) Mannose receptor ligands stimulate secretion of lysosomal enzymes from rabbit alveolar macrophages. J.Biol.Chem. 262, 7955-7962.

13 Shepherd, V.L., Konish, M.G., Stahl, P. (1985) Dexamethasone increases expression of mannose receptors and decreases extracellular lysosomal enzyme accumulation in macrophages. J.Biol.Chem. 260, 160-164.

14 Imber, M.J., Pizzo, S.V., Johnson, W.J., Adams, D.O. (1982) Selective diminution of the binding of mannose by murine macrophages in the late stages of activation. J.Biol.Chem. 257, 5129-5135.

15 Mokoena, T., Gordon, S. (1985) Human macrophage activation. Modulation of mannosyl, fucosyl receptor activity in vitro by lymphokines, gamma and alpha interferons, and dexamethasone. J.Clin.Invest. 75, 624-631.

16 Brock, J., Schulze, H.A., Neels, P., Fischer, A., Bremer, H., Walzel, H. (1991) Detection of mannose-binding proteins on mouse lymphocytes. Eur.J.Cell Biol. 54, 90-94.

17 Steinbach, F., Thiele, B. (1994) Phenotypic investigation of mononuclear phagocytes by flow cytometry. J.Immunol.Meth. 174, 109-122.

18 Barrett-Bergshoeff, M., Noorman, F., Bos, R., Rijken, D.C. Monoclonal antibodies against the human mannose receptor that inhibit the binding of tissue-type plasminogen activator. submitted. Chapter 3 of this thesis.

19 Pulford, K.A.F., Rigney, K.J., Micklem, K.J., Jones, M., Stross, W.P., Gatter, K.C., Mason, D.Y. (1989) KP1: a new monoclonal antibody that detects a monocyte/macrophage associated antigen in routinely processed tissue sections. J.Clin.Pathol. 42, 414-421.

20 Pulford, K.A., Sipos, A., Cordell, J.L., Stross, W.P., Mason, D.Y. (1990) Distribution of the CD68 macrophage/myeloid associated antigen. Int.Immunol. 2, 973-980.

21 Van der Meer, J.W.M., Van de Gevel, J.S., Blusse van Oud Alblas, A., Kramps, J.A., van Zwet, T.L., Leijh, P.C.J., van Furth, R. (1982) Characteristics of human monocytes cultured in a teflon culture bag. Immunology 47, 617-625.

22 Otter, M., Zockova, P., Kuiper, J., van Berkel, T.J.C., Barrett-Bergshoeff, M.M., Rijken, D.C. (1992) Isolation and characterization of the mannose receptor from human liver potentially involved in the plasma clearance of tissue-type plasminogen activator. Hepatology 16, 54-59.

23 Schmid, I., Schmid, P., Giorgi, J.V. (1988) Conversion of logarithmic channel numbers into relative linear fluorescence intensity. Cytometry 9, 533-538.

24 Li, C.Y., Yam, L.T., Crosby, W.H. (1972) Histochemical characterization of cellular and structural elements of the human spleen. J.Hist.Cytochem. 20, 1049-1058.

25 Stahl, P., Schlesinger, P.H., Sigardson, A., Rodman, J.S., 
Lee, Y.C. (1980) Receptor mediated pinocytosis of mannose glycoconjugates by macrophages: characterization and evidence for receptor recycling. Cell 19, 207-215.

26 Shepherd, V.L., Campbell, E.J., Senior, R.M., Stahl, P.D. (1982) Characterization of the mannose/fucose receptor on human mononuclear phagocytes. J.Reticuloendoth.Soc. 32, 423-431.

27 Shepherd, V.L., Abdorasulnia, R., Garrett, M., Cowan, H.B. (1990) Down-regulation of mannose receptor activity in macrophages after treatment with lipopolysaccharide and phorbol esters. J.Immunol. 145, 1530-1536.

28 Cowan, H.B., Vick, S., Conary, J.T., Shepherd, V.L. (1992) Dexamethasone up-regulates mannose receptor activity by increasing mRNA levels. Arch.Biochem.Biophys. 296,314320.

29 Stein, S., Keshav, S., Harris, N., Gordon, S. (1992) Interleukin 4 potently enhances murine macrophage mannose receptor activity: a marker of altemative immunologic macrophage activation. J.Exp.Med. 176, 287 292.

30 Sallusto, F., Lanzavecchia, A. (1994) Efficient presentation of soluble antigen by cultured human dendritic cells is maintained by granulocyte/macrophage colony stimulating factor plus interleukin 4 and downregulated by tumor necrosis factora. J.Exp.Med. 179, 1109-1118.

31 Hanasaki, K., Arita, H. (1992) Characterization of a high affinity binding site for pancreatic-type phospholipase A2 in the rat. Its cellular and tissue distribution. J.Biol.Chem. 9, 6414-6420.

32 Ishizaki, J., Hanasaki, K., Higashino, K., Kishino, J., Kikuchi, N., Ohara, O., Arita, H. (1994) Molecular cloning of pancreatic group I phospholipase A2 receptor. J.Biol.Chem. 8, 5897-5904

33 Jiang, W., Swiggard, W.J., Heufler, C., Peng, M., Mirza, A., Steinman, R.M., Nussenzweig, M.C. (1995) The receptor DEC-205 expressed by dendritic cells and thymic epithelial cells is involved in antigen processing. Nature 375, 151-154.

34 Reis e Sousa, C., Stahl, P.D., Austyn, J.M. (1993) Phagocytosis of antigens by Langerhans cells in vitro. J.Exp.Med. 178, 509-519.

35 Muchmore, A.V., Sathyamoorthy, N., Decker, J., Sherblom, A.P. (1990) Evidence that specific high-mannose oligosaccharides can directly inhibit antigen-driven T-cell responses. J.Leukocyt.Biol. 48, 457-464.

36 Steinmann, R.M. (1991) The dendritic cell system and its role in immunogenicity. Annu.Rev.Immunol. 9, 271-296. 


\section{CHAPTER 5}

Expression of the human mannose receptor under physiological and pathological conditions. An immunohistochemical study using monoclonal antibody 15-2

Femke Noorman, Ellis Barbé*, Alexander van Leeuwen", Jan Lindeman and Dingeman C. Rijken.

Gaubius Laboratory, TNO Prevention and Health, Leiden, The Netherlands.

* Department of Pathology, Slotervaart Hospital, Amsterdam, The Netherlands.

Manuscript submitted. 


\section{SUMMARY}

The $175 \mathrm{kDa}$ mannose receptor has been shown to be involved in different processes such as clearance, antigen uptake and fusion of macrophages into giant cells. The mannose receptor expression on macrophages is downregulated by activation and upregulated by alternative activation of macrophages in vitro. Recently we developed a specific monoclonal antibody (mAb) that recognizes the human mannose receptor, mAb 15-2. In the current report the expression of the human mannose receptor under physiological and pathological conditions was immunohistochemically studied in tissues by the use of mAb 15-2.

Under physiological conditions, the mannose receptor was expressed on resident macrophages, liver and splenic sinusoidal endothelial cells, spermatozoa and spermatids. In tuberculosis and leprosy, in rheumatoid arthritis and in breast carcinoma the macrophages were probably activated as the mannose receptor expression by macrophages appeared to be downregulated. In contrast, in a foreign body reaction the macrophages were probably alternatively activated as the mannose receptor expression by macrophages appeared to be upregulated.

It is concluded that only a few human cell types express the mannose receptor. As previously shown in vitro, the mannose receptor expression on macrophages probably reflects the type of macrophage activation in vivo. mAb 15-2 is a specific tool to study the mannose receptor expression in human tissues.

\section{INTRODUCTION}

The $175 \mathrm{kDa}$ mannose receptor is expressed by macrophages in vitro. Antagonists of the mannose receptor inhibit the uptake and degradation of high mannose-type oligosaccharide containing glycoproteins such as lysosomal enzymes ${ }^{1}$ and tissue-type plasminogen activator (t-PA). ${ }^{2}$ They also inhibit the complement-independent uptake of pathogenic organisms that have polymannose structures on their membrane. ${ }^{3}$ Mannose receptor-mediated uptake results in either intracellular degradation of organisms such as Candida albicans, or intracellular survival of parasites such as Mycobacterium tuberculosis. ${ }^{3}$ It also plays an important role in the antigen uptake and processing by dendritic cells $\mathrm{s}^{4,5}$ and fusion of macrophages into foreign body-type giant cells after interleukin-4 stimulation. ${ }^{6}$ Furthermore the mannose receptor expressed on other cell types appears to mediate the plasma clearance of high mannose-type oligosaccharide containing glycoproteins in the liver, ${ }^{7,8}$ the homing of lymphocytes to the spleen, ${ }^{9,10}$ sperm fertility ${ }^{11}$ and the induction of alveolar smooth muscle cell proliferation. ${ }^{12,13}$

It has been suggested that the mannose receptor may be of clinical interest for therapeutic interventions. For example, the mannose receptor is a potential target for the specific delivery of drugs to macrophages. ${ }^{14,15}$ Furthermore, the receptor ligand t-PA is an enzyme that activates fibrinolysis and it has been shown that an increased plasma t-PA concentration present during thrombus formation reduces the thrombus formation in the rat. ${ }^{16}$ Thus blockage of the mannose receptor-mediated plasma clearance or t-PA may pe of interest in antithrombotic therapy. ${ }^{17}$ 
In vitro, the expressional state of the mannose receptor highly correlates with the functional state of the monocyte/macrophage. Macrophages express the mannose receptor whereas no expression is seen on monocytes. ${ }^{2,18,19}$ High mannose receptor expression correlates with the antigen uptake capacity of dendritic cells ${ }^{4}$ and increases foreign body-type giant cell formation. Immunosuppressed or alternatively activated macrophages have a high mannose receptor expression, ${ }^{2,4,19-22}$ whereas activated macrophages and dendritic cells have a low mannose receptor expression. ${ }^{2,4,19,21-23}$ The mannose receptor may thus be a good marker for distinguishing between these macrophage phenotypes.

Although a number of studies have been performed on the expression of the mannose receptor under specific conditions in vitro, the in vivo expression of the mannose receptor has not been documented in detail. Recently we developed a monoclonal antibody ( $\mathrm{mAb}$ ) specific for the human mannose receptor (mAb 15-2). ${ }^{24} \mathrm{In}$ this report the expression of the mannose receptor under physiological and pathological conditions is evaluated by the use of mAb 15-2. Because it has been suggested that in most of the pathological conditions studied, macrophages are of crucial importance, we compared the mannose receptor expression to the expression of the commonly used pan-macrophage marker, the CD68 antigen, by the use of mAb KP-1. ${ }^{25,26}$

\title{
MATERIALS AND METHODS
}

\begin{abstract}
Materials
Mouse monoclonal antibody KP-1 (isotype $\operatorname{lgG}_{1}$ ) against the human $\mathrm{CD} 68$ antigen was purchased from Dako A/S (Glostrup, Denmark). Mouse monoclonal antibody mAb 15-2 (isotype $\lg G_{1}$ ) has been raised against the human mannose receptor, isolated from placenta as described ${ }^{24}$ (Gaubius laboratory, Leiden, The Netherlands). This mAb detects the $175 \mathrm{kDa}$ mannose receptor in Western blot, ${ }^{24}$ inhibits the binding of t-PA to the mannose receptor, ${ }^{24}$ detects up- or downregulation of the macrophage mannose receptor expression by use of flow cytometry, ${ }^{19}$ and can be used to detect mannose receptor expression in immunohistochemistry. ${ }^{19}$
\end{abstract}

\section{Immunohistochemistry}

Tissue obtained from autopsies and tissue biopsies obtained from patients for diagnostic purposes (Department of Pathology, Slotervaart Hospital, Amsterdam, The Netherlands) were snap frozen in liquid nitrogen. Diagnosis of tissues affected by disease was performed by pathologists using standard protocols. A modification of the immuno-alkaline-phosphatase method described by Li et al. ${ }^{27}$ was used for tissue staining. Sections of $8 \mu \mathrm{m}$ thickness were cut on a Reichert-Jung 2800 frigocut cryostat, transferred to poly-Llysine-coated microscope slides, air dried and fixed in acetone (10 $\mathrm{min}$ at room temperature), rinsed (5 $\mathrm{min}$ ) in phosphate-buffered saline (PBS), and incubated with primary antibody ( $1 \mu \mathrm{g} / \mathrm{ml} \mathrm{mAb} 15-2,1: 2000$ dilution of $\mathrm{KP}-1)$ for $30 \mathrm{~min}$ at room temperature. After rinsing in PBS (5 $\mathrm{min}$ ), the sections were incubated with an alkaline-phosphatase-conjugated secondary antibody (rabbit anti-mouse, Dako AS, Glostrup, Denmark) for $15 \mathrm{~min}$ at room temperature. After rinsing in PBS (5 $\mathrm{min}$ ) the sections were incubated for $30 \mathrm{~min}$ at room temperature in the dark with naphtol-AS-MX-phosphate (Sigma Chemical Co., St.Louis, MO, USA) and New Fuchsine (Chroma Gezellschaft, Köngen, Germany) as a coupling salt to develop a red reaction product. Finally the sections were rinsed with aqua dest, counterstained with Mayers hematoxylin, and mounted in DePeX mounting medium (BDH, Poole, UK). In control sections no primary antibody was used. The identity of the cells was judged on the basis of their morphology and their location in the tissue. 


\section{RESULTS}

\section{Mannose receptor expression under physiological conditions}

The expression of the mannose receptor and CD68 on cells in healthy tissues is summarized in Table 1 , which includes some data that were recently published elsewhere. In all tissues only macrophages (including the perivascular glial cells and the synovial lining cells) were both CD68- and mannose receptor-positive. KP-1 and mAb 15-2 stained these macrophages with equal strength in healthy tissues. KP-1 and not mAb 15-2, stained monocytes, granulocytes, macrophages in thymus medulla, macrophages in the B cell areas of lymphoid tissue, Langerhans cells, brain microglia cells, and some endothelial and epithelial cells. In the liver and in the spleen mAb 15-2 and not KP-1, abundantly stained the sinusoidal endothelial cells (Fig 1A,B see appendix, page 140). In testis, the macrophages were both CD68- and mannose receptor-positive, the Leydig cells were only CD68-positive and the spermatids and spermatozoa were only mannose receptor-positive (Fig 1C,D see appendix, page 141).

TABLE 1 Tissue distribution of the mannose receptor and CD68 under physiological conditions.

Cryostat sections of human tissue were stained with mAb KP-1 or 15-2, and the staining patterns were compared with each other and to that of tissues stained without primary mAb. + positive cells, $+(-)$ marker stained less cells than other marker, $-(+)$ very few cells stain positive, - no staining observed, * mantle zone and germinal centre.

\begin{tabular}{|c|c|c|c|c|c|c|c|}
\hline Tissue, location & cell type & KP-1 & $15-2$ & Tissue, location & cell type & KP-1 & $15-2$ \\
\hline \multirow[t]{6}{*}{ Bone marrow ${ }^{19}$} & & & & Colon & & & \\
\hline & lymphocytes & - & - & mucosa & macrophages & + & + \\
\hline & granulocytes & + & - & submucosa & macrophages & + & + \\
\hline & monocytes & + & - & & & & \\
\hline & megakaryocytes & - & - & Brain & & & \\
\hline & macrophages & + & + & & microglia cells & + & - \\
\hline \multirow{5}{*}{$\begin{array}{l}\text { Thymus }^{19} \\
\text { cortex } \\
\text { medulla }\end{array}$} & & & & & perivascular glial cells & + & + \\
\hline & macrophages & + & + & & & & \\
\hline & macrophages & + & $-(+)$ & Placenta ${ }^{24}$ & & & \\
\hline & round cells & + & - & & Hofbauer cells & + & + \\
\hline & endothelium & + & - & & endothelial cells & + & - \\
\hline \multicolumn{4}{|l|}{ Lymph node $^{19}$} & Testis (Fig 1B) & & & \\
\hline subcapsular sinus & macrophages & + & + & & macrophages & + & + \\
\hline T cell area & macrophages & + & $+(-)$ & & Leydig cells & + & - \\
\hline B cell area* & macrophages & + & $-(+)$ & & spermatids & - & + \\
\hline medulla & macrophages & + & + & & spermatozoa & - & + \\
\hline \multirow{3}{*}{$\begin{array}{l}\text { Spleen (Fig 1A) } \\
\text { red pulp }\end{array}$} & & & & Skin $^{19}$ & & & \\
\hline & sinusoidal cells & - & + & epidermis & Langerhans cells & + & - \\
\hline & macrophages & \multicolumn{3}{|c|}{ white pulp } & & & + \\
\hline marginal zone & macrophages & + & $+(-)$ & Lung & & & \\
\hline \multirow[t]{2}{*}{ germinal centre } & macrophages & + & $-(+)$ & & smooth muscle cells & - & - \\
\hline & & & & & endothelium & + & - \\
\hline \multirow[t]{5}{*}{ Liver $^{17}$} & & & & & alveolar macrophages & + & + \\
\hline & sinusoidal cells & - & + & & tissue macrophages & + & + \\
\hline & Kupffer cells & + & + & & & & \\
\hline & parenchymal cells & - & - & Trachea & & & \\
\hline & & & & & macrophages & + & + \\
\hline Kidney & & & & & smooth muscle cells & - & - \\
\hline glomerulus & mesangial macrophages & + & + & & & & \\
\hline proximal tubulus & epithelial cells & + & - & Synovium & & & \\
\hline \multirow{2}{*}{ around tubuli } & macrophages & + & + & & synovial lining cells & + & + \\
\hline & & & & & macrophages & + & + \\
\hline \multirow{3}{*}{ Heart } & endothelium & + & - & Breast & & & \\
\hline & heart muscle cells & - & - & & macrophages & + & + \\
\hline & macrophages & + & + & & & & \\
\hline
\end{tabular}




\section{Mannose receptor expression under pathological conditions}

As macrophages play an important role in granulomatous diseases, we studied the granulomatous diseases cutaneous tuberculoid leprosy, tuberculosis in the lung, and a reaction to polyethylene in the synovium (Table 2). The strength of the CD68 staining with KP-1 was not affected under these conditions (Fig 2A see appendix, page 144). In leprosy and tuberculosis, mAb 15-2 did not stain or only weakly stained the macrophages surrounding the (Langhans-type) giant cells (Fig 2B,C see appendix, page 144). In a synovium with macrophages reacting to polyethylene (foreign body reaction), mAb 15-2 strongly stained the macrophages surrounding the (foreign body-type) giant cells (Fig 2D see appendix, page 144). mAb 15-2 did not stain or only weakly stained both Langhans-type giant cells and foreign body-type giant cells (Fig 2B-D).

Healthy synovial lining cells expressed both the CD68 antigen and the mannose receptor (Table 1). In rheumatoid arthritis, hypertrophy and hyperplasia of the synovial lining cells was observed. Morphologically these cells appeared to be macrophages and the complete layer was CD68-positive. However, only a few cells of the hypertrophic and hyperplastic synovial lining cells were weakly mAb 152-positive (Fig 2E,F see appendix, page 145). In contrast to the stroma of normal breast, no mAb 15-2positive macrophages were observed in the desmoplastic tumorstroma of breast carcinoma of both the ductal (Fig 2G,H see appendix, page 145) and the lobular type (not shown). Stromal macrophages in both normal breast and breast carcinoma were CD68-positive.

TABLE 2 Tissue distribution of the mannose receptor and CD68 under pathological conditions.

Cryostat sections of human tissue were stained with mAb KP-1 or 15-2, and the staining patterns were compared with each other and to that of tissues stained without primary $\mathrm{mAb}$. + positive cells, ++ strong staining, $-1+$ weak staining, - no staining observed,

( 1 ) mannose receptor upregulated and $(\downarrow)$ mannose receptor downregulated compared with physiological condition.

Disease, tissue, location

cell type

KP-1

15-2

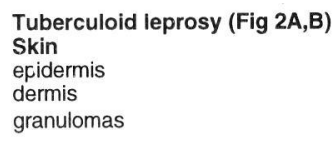

Tuberculosis (Fig 2C)

Lung

granulomas

lymph aggregates

Foreign body reaction (Fig 2D)

Synovium

lymph aggregates

Rheumatoid arthritis (Fig 2E,F)

Synovium

Ductal/lobular carcinoma (Fig 2G,H)

Breast

normal stroma

desmoplastic tumor stroma
Langerhans cells

macrophages

macrophages

Langhans-type giant cells

alveolar macrophages

tissue macrophages

pallisad macrophages

Langhans-type giant cells

macrophages

synovial lining cells

stromal macrophages

foreign body-type giant cells

macrophages

Hypertrophic and hyperplastic

synovial lining cells

stromal macrophages

macrophages

macrophages
$-1+$

$+1+(1)$

$-1+$
$-1+$

-

++ (1)

$-1+$

$+$

$\begin{array}{llll}+ & -1+ & (\downarrow) \\ + & + & \\ + & + & \\ + & - & (1)\end{array}$




\section{DISCUSSION}

The expression and functions of the mannose receptor have been studied in vitro, however the in vivo expression of the mannose receptor is not documented in detail. We studied the expression of the human mannose receptor in human tissues under various conditions by immunohistochemistry using the recently-developed mAb 15-2. ${ }^{19,24}$

Many studies have suggested the involvement of the mannose receptor when a process was inhibited by ligands of the mannose receptor. However, there are other mannose-binding proteins that are able to bind mannose receptor ligands. ${ }^{28-32}$ Thus inhibition of a process by mannose receptor ligands does not prove that the mannose receptor is involved. Because mAb 15-2 does not recognize these other mannose-binding proteins, ${ }^{19}$ it is a useful tool for providing evidence for the involvement of the $175 \mathrm{kDa}$ mannose receptor. This is illustrated by the observation that in the present study no mannose receptor was expressed by smooth muscle cells at all, while the mannose receptor has been reported to mediate mannose receptor ligand-induced proliferation by tracheal smooth muscle cells in vitro. ${ }^{12,13}$ The discrepancy suggests that not the mannose receptor but another receptor is involved in this process. This other receptor might be the $180 \mathrm{kDa}$ phospholipase $\mathrm{A} 2$ receptor; the receptor contains domains similar to the mannose receptor, ${ }^{31}$ it binds mannose receptor ligands, and phospholipase A2 induces DNA synthesis in smooth muscle cells. ${ }^{32,33}$ The $180 \mathrm{kDa}$ phospholipase A2 receptor is not detected by mAb 15-2. ${ }^{19}$

\section{Mannose receptor expression under physiological conditions.}

The mannose receptor was expressed by resident (stromal) macrophages in nearly all vital organs under normal conditions. In contrast to CD68, the mannose receptor was not expressed by follicular dendritic cells in the germinal centres of lymphoid tissue (Fig 1A). As discussed previously ${ }^{19}$ macrophages expressing both $\mathrm{CD} 68$ and the mannose receptor, represent non-activated macrophages or dendritic cells, while macrophages which express CD68 but not the mannose receptor, represent activated macrophages or dendritic cells. mAb 15-2 directed against the mannose receptor thus is an important tool in discriminating between non-activated macrophages/dendritic cells and activated macrophages/dendritic cells.

Besides the expression by macrophages, the mannose receptor was abundantly expressed by liver $\left(\mathrm{see}^{17}\right.$ ) and splenic sinusoidal endothelial cells (Fig 1A), but not by endothelium in other organs. This suggests that the mannose receptor has a specific role in liver and spleen. As shown by plasma clearance and tissue distribution studies the uptake and degradation of mannose receptor ligands such as t-PA and mannosylated albumin from plasma is mainly mediated by the liver and not by the spleen. ${ }^{8,34}$ Mannose receptor ligands have been used for the specific delivery of genes to mannose receptor-expressing cells in gene therapy. After injection of an expression plasmid conjugated to a mannose receptor ligand, a low expression of the gene was found in the liver whereas a high expression was found in the spleen. ${ }^{15}$ This suggests that in contrast to the mannose receptor on liver sinusoidal endothelial cells, ${ }^{35}$ the mannose receptor on splenic sinusoidal endothelial cells does not mediate efficient degradation of its ligands. Instead, the mannose receptor in the spleen appears to be involved in the homing of lymphocytes to the spleen, since mannan, a ligand for the mannose receptor, binds to the splenic sinusoidal endothelium, and has been shown to inhibit the splenic entry of lymphocytes in vivo. ${ }^{9,10}$ 
In brain tissue we found a single cell layer of mannose receptor-positive cells directly below the endothelium of blood vessels (these cells are the perivascular glial cells ${ }^{36}$ ), whereas the microglial cells were mannose receptor-negative. The perivascular glial cells are thought to be involved in the antigen presentation to encephalitogenic $T$ cells in experimental autoimmune encephalomyelitis (EAE, an animal model for multiple sclerosis). ${ }^{36}$ The mannose receptor has been shown to be involved in antigen presentation by young dendritic cells in vitro. ${ }^{4,5} \mathrm{It}$ is possible that the mannose receptor has a similar role in antigen presentation by perivascular glial cells. In addition, the mannose receptor may play a role in the blood-brain barrier by the uptake and degradation of mannose receptor ligands such as lysosomal enzymes ${ }^{1,7} \mathrm{t}-\mathrm{PA},{ }^{2,8}$ dopamine $\mathrm{B}$ hydroxylase ${ }^{37}$ and acetylcholinesterase. ${ }^{38}$

The mannose receptor was expressed on spermatids and spermatozoa (Fig 1B). Possibly the mannose receptor is involved in the fusion of sperm with the egg, as described for the involvement of the mannose receptor in the fusion of macrophages into foreign body-type giant cells, ${ }^{6}$ but this remains to be shown. It has been shown that the mannose-albumin binding capacity of sperm cells correlates with the fertility of the sperm cells. ${ }^{11}$ It is likely that the mannose receptor mediates the binding of mannose-albumin (a mannose receptor ligand) in the above-mentioned study, and that the mannose receptor expression thus may correlate with sperm fertility.

\section{Mannose receptor expression under pathological conditions}

In vitro, the expression of the mannose receptor is upregulated by interleukin-4, ${ }^{20}$ interleukin-13, ${ }^{21}$ dexamethasone ${ }^{2,19,22}$ and prostaglandin E2. ${ }^{23}$ On the other hand the mannose receptor activity is downregulated by lipopolysaccharide, ${ }^{2,19} y$-interferon ${ }^{21-23}$ or tumor necrosis factor- $\alpha,{ }^{4}$ substances known to activate macrophages. It has been suggested that interleukin-4 activates macrophages (alternative activation) in a different way from $\mathrm{y}$-interferon. ${ }^{20}$ We have demonstrated previously that in flow cytometry, mAb 15-2 is able to detect mannose receptor downregulation on lipopolysaccharidetreated macrophages and mannose receptor upregulation on dexamethasone-treated macrophages in vitro. ${ }^{19}$ Thus the intensity of staining with mAb 15-2 correlates with the amount of mannose receptor expressed by the cells. Here we demonstrated in human tissues that, compared with physiological conditions, under various pathological conditions the staining with $\mathrm{mAb}$ 15-2 was weaker or stronger on macrophages, whereas the staining with KP-1 was not altered. This indicates that the mannose receptor expression is down- or upregulated under these conditions in vivo.

In the granulomatous diseases studied, the mannose receptor was absent or only weakly expressed on both foreign body-type and Langhans-type giant cells. On the macrophages surrounding the foreign body-type giant celis, the mannose receptor appeared to be upregulated, whereas on the macrophages surrounding the Langhans-type giant cells the mannose receptor appeared to be downregulated (Fig $2 A, B)$. This indicates that the macrophages in these granulomas are activated by different cytokines. The mannose receptor has been implicated as being involved in the fusion of macrophages into foreign body-type giant cells, since in vitro the formation can be inhibited by mannose receptor ligands. ${ }^{6}$ Foreign body-type giant cell formation from macrophages is induced in vitro by interleukin-4 (T-helper 2 cytokine) treatment ${ }^{6,39}$ that also upregulates the mannose receptor expression. 6,20,21 In contrast Langhans-type giant cell formation from macrophages is induced in vitro by $\mathrm{Y}$-interferon (T-helper 1 cytokine) ${ }^{39}$ which downregulates mannose receptor expression. ${ }^{21-23}$ Thus the differences observed in mannose receptor expression in these granulomas possibly reflects the regulation by cytokines present in these human tissues in vivo. 
In infectious granulomatous diseases such as tuberculoid leprosy and tuberculosis (Fig 2A,B) the mannose receptor appeared to be downregulated on the macrophages. Phagocytosis of virulent strains but not the less aggressive (attenuated) strains of Mycobacterium tuberculosis is mediated by the mannose receptor in addition to complement receptors in vitro. ${ }^{40}$ Similarly, the parasites Trypanosoma cruzi and Leishmani donovani enter their host, the macrophage, via the mannose receptor. ${ }^{3}$ The downregulation of the mannose receptor on macrophages may thus be an important defence mechanism against these pathogens.

In normal synovium the mannose receptor and the CD68 antigen were present in the macrophage-like cells, the synovial lining cells. In rheumatoid arthritis hyperplasia and hypertrophy of synovial lining cells was apparent (Fig 2E). This hyperplastic layer of cells was composed of CD68-positive and mannose receptor-negative (activated) macrophages. Because these activated macrophages are possibly involved in the tissue destruction seen in rheumatoid arthritis, it is of clinical importance to study their role in further detail. mAb 15-2 can be used to discriminate between activated and non-activated macrophages.

In the breast carcinomas studied here, the macrophages in the tumor stroma did not express the mannose receptor; this is in contrast to the macrophages in normal breast stroma (Fig 2D). This indicates that strong macrophage activation signals are present inside these tumors. Whether this activation is part of the defence mechanism of the body against the tumor or a defence mechanism of the tumor against the body (for example to avoid antigen presentation) remains to be shown. It would be interesting to study whether there is a correlation between macrophage mannose receptor expression and tumor malignancy.

Recently Uccini et al. ${ }^{41}$ reported that the mannose receptor is expressed on Kaposi's sarcoma cells and that these cells are possibly related to splenic sinusoidal endothelial cells. As mAb 15-2 is capable of detecting mannose receptor-expressing cells by use of flow cytometry, ${ }^{19} \mathrm{mAb} 15-2$ may be an useful tool in detecting (precursors of) these sarcoma cells in peripheral blood for diagnostic purposes, but this remains to be shown.

We conclude that only a few cell types express the mannose receptor in man and that, as observed in vitro, the mannose receptor may be up- or down- regulated on macrophages in human tissues under pathological conditions in vivo. The anti-mannose receptor mAb 15-2 is a specific marker for nonactivated macrophages, liver and splenic sinusoidal endothelial cells, and is possibly a marker for fertile sperm.

\section{ACKNOWLEDGEMENTS}

We wish to thank Arjan Daemen for expert photographic assistance and Dr J.D. Laman and Dr J.J. Emeis for their critical evaluation of this manuscript. This study was financially supported by the Netherlands Heart Foundation grant no. 90.294. 


\section{REFERENCES}

1 Stahl PD, Somsel Rodman J, Miller MJ, Schlesinger PH: Evidence for receptor-mediated binding of glycoproteins, glycoconjugates, and lysosomal glycosidases by alveolar macrophages. Proc Nat Acad Sci USA 1978, 75:13991403

2 Noorman F, Braat EAM, Rijken DC: Degradation of tissuetype plasminogen activator by human monocyte-derived macrophages is mediated by the mannose receptor and by the low density lipoprotein receptor-related protein. Blood 1995, 86:3421-3427. Chapter 2 of this thesis.

3 Ofec I, Goldhar J, Keisari Y, Sharon N: Nonopsonic phagocytosis of microorganisms. Annu Rev Microbiol 1995, 49:239-276

4 Sailusto F, Cella M, Danieli C, Lanzavecchia A: Dendritic cells use macropinocytosis and the mannose receptor to concentrate macromolecules in the major histocompatibility complex class II compartment: Downregulation by cytokines and bacterial products. J Exp Med 1995, 182:389-400

5 Prigozy TI, Sieling PA, Clemens D, Stewart PL, Behar SM, Porcelli SA, Brenner MB, Modlin RL, Kronenberg M: The mannose receptor delivers lipoglycan antigens to endosomes for presentation to T cells by CD1b molecules. Immunity 1997, 6:187-197

6 MCNally AK, DeFife KM, Anderson JM: Interleukin-4induced macrophage fusion is prevented by inhibitors of mannose receptor activity. Am J Pathol 1996, 149:975-985

7 Koster A, van Figura K, Pohlmann R: Mistargeting of lysosomal enzymes in $\mathrm{Mr} 46000$ mannose-6-phosphate receptor deficient mice is compensated by carbohydratespecific endocytotic receptors. Eur J Biochem 1994, 224:685-689

8 Kuiper J, Otter M, Rijken DC, van Berkel ThJC: Characterization of the interaction in vivo of tissue-type plasminogen activator with liver cells. J Biol Chem 1988, 266:13931-13935

9 Weston SA, Parish CR: Modification of lymphocyte migration by mannans and phosphomannans. Different carbohydrate structures control entry of lymphocytes into spleen and lymph nodes. J Immunol 1991, 146:4180-4186

10 Weston SA, Parish CR: Evidence that mannose recognition by splenic sinusoidal cells plays a role in the splenic entry of lymphocytes. Eur J Immunol 1992, 22:1975-1981

11 Benoff S, Hurley I, Cooper GW, Mandel FS, Hershlag A, Scholl GM, Rosenfeld DL: Fertilization potential in vitro is correlated with head-specific mannose-ligand receptor expression, acrosome status and membrane cholesterol content. Hum Reprod 1993, 8:2141-2154

12 Lew DB, Rattazzi MC: Mitogenic effect of lysosomal hydrolases on bovine tracheal myocytes in culture. $\mathrm{J}$ Clin Invest 1991, 88:1969-1975

13 Lew DB, Songu-Mize E, Pontow SE, Stahl PD, Rattazzi MC: A mannose receptor mediates mannosyl-rich glycoprotein-induced mitogenesis in bovine airway smooth muscle cells. J Clin Invest 1994, 94:1855-1863

14 Sato $Y$, Beutler E: Binding, internalization, and degradation of mannose-terminated glucocerebrosidase by macrophages. J Clin Invest 1993, 91:1909-1917

15 Ferkol T, Perales JC, Mularo F, Hanson RW: Receptormediated gene transfer into macrophages. Proc Nat Acad Sci USA 1996, 93:101-105

16 Emeis JJ, Bekkers M: Low-dose infusion of tissue-type plasminogen activator ( $t-P A)$ prevents arterial thrombosis in a rat thrombosis model: t-PA as an antithrombotic agent. Fibrinolysis 1996, 10 Suppl 3:128

17 Noorman F, Barrett-Bergshoeff MM, Biessen EAL, van de Bilt E, van Berkel ThJC, Rijken DC: Cluster mannosides can inhibit mannose receptor-mediated tissue-type plasminogen activator (t-PA) degradation by both rat and human cells. Hepatology 1997, in press. Chapter 7 of this thesis.

18 Shepherd VL, Campbell EJ, Senior RM, Stahl PD: Characterization of the mannose/fucose receptor on human mononuclear phagocytes. J Reticuloendoth Soc 1988, 32:423-431

19 Noorman F, Braat EAM, Barrett-Bergshoeff MM, Barbé E, van Leeuwen $A$, Lindeman J, Rijken DC: Monoclonal antibodies against the human mannose receptor as a specific marker in flow cytometry and immunohistochemistry for macrophages. J Leukoc Biol 1997, 61:63-72. Chapter 4 of this thesis.

20 Stein M, Keshav S, Harris N, Gordon S: Interleukin 4 potently enhances murine macrophage mannose receptor activity: a marker of altemative immunologic macrophage activation. J Exp Med 1992, 176:287-292

21 Doyle AG, Herbein G, Montaner LJ, Minty AJ, Caput D, Ferrera $P$, Gordon S: Interleukin-13 alters the activation state of murine macrophages in vitro: comparison with interleukin-4 and interferon-y. Eur J Immunol 1994, 24:1441-1445

22 Shepherd VL, Cowan HB, Abdolrasulnia R, Vick S: Dexamethasone blocks the interferon- $\gamma$-mediated downregulation of the macrophage mannose receptor. Arch Biochem Biophys 1994, 312:367-374

23 Schreiber S, Perkins SL, Teitelbaum SL, Chappel J, Stahl PD, Blum JS: Regulation of mouse bone marrow macrophage mannose receptor expression and activation by prostaglandin E and IFN-Y. J Immunol 1993, 151:49734981

24 Barrett-Bergshoeff MM, Noorman F, Bos R, Rijken DC: Monoclonal antibodies against the human mannose receptor that inhibit the binding of tissue-type plasminogen activator. Thromb Haemostas 1997, 77:718-724. Chapter 3 of this thesis.

25 Pulford KA, Rigney KJ, Micklem KJ, Jones M, Stross WP, Gatter KC, Mason DY: KP1: a new monoclonal antibody that detects monocyte/macrophage associated antigen in routinely processed tissue sections. J Clin Pathol 1989, 42:414-421 
26 Pulford KA, Sipos A, Cordell JL, Stross WP, Mason DY: Distribution of the CD68 macrophage/myeloid associated antigen. Int Immunol 1990, 2:973-980

$27 \mathrm{Li}$ CY, Yam LT, Crosby WH: Histochemical characterization of cellular and structural elements of the human spleen. J Histochem Cytochem 1972, 20:10491058

28 Childs RA, Feizi T, Yuen CT, Drickamer K, Quesenberry MS: Differential recognition of core and terminal portions of oligosaccharide ligands by carbohydrate-recognition domains of two mannose-binding proteins. J Biol Chem 1990, 265:20770-20777

29 Kubak BM, Potempa LA, Anderson B, Mahklouf S, Venegas M, Gewurz H, Gewurz AT: Evidence that serum amyloid $\mathrm{P}$ component binds to mannose-terminated sequences of polysaccharides and glycoproteins. Mol Immunol 1988, 25: 851-858

30 Jiang W, Swiggard WJ, Heufler C, Peng M, Mirza A, Steinman RM, Nussenzweig MC: The receptor DEC-205 expressed by dendritic cells and thymic epithelial cells is involved in antigen processing. Nature 1995, 375:151-154

31 Ishizaki J, Hanasaki K, Higashino K, Kishino J, Kikuchi N, Ohara $\mathrm{O}$, Arita $\mathrm{H}$ : Molecular cloning of pancreatic group I phospholipase A2 receptor. J Biol Chem 1994, 269:58975904

32 Nicolas JP, Lambeau G, Lazdunski M: Identification of the binding domain for secretory phospholipases $\mathrm{A} 2$ on their M-type 180-kDa membrane receptor. J Biol Chem 1995, 270:28869-28873

33 Hanasaki K, Arita $\mathrm{H}$ : Characterization of a high affinity binding site for pancreatic-type phospholipase A2 in the rat. Its cellular and tissue distribution. J Biol Chem 1992, 267:6414-6420

34 Rushfeldt C, Smedsrød B: Significant differences in serum clearance, and anatomical and hepatocellular distribution of 1251-labelled neoglycoproteins - implications for rate of elimination and targetting of drugs. Cells of the Hepatic
Sinusoid Vol 5. Edited by Wisse E, Knook DL, Wake K. Leiden, Kupffer Cell Foundation, 1995, pp. 180-183

35 Praaning-van Dalen DP, de Leeuw AM, Brouser A, Knook DL: Rat liver endothelial cells have a greater capacity than Kupffer cells to endocytose $\mathrm{N}$-acetylglucosamine- and mannose- terminated glycoproteins. Hepatology 1987 7:672-679

36 Bauer J, Ruuls SR, Huitinga I, Dijkstra CD: The role of macrophage subpopulations in autoimmune disease of the central nervous system: Histochem J 1996, 28:83-97

37 Munoz A, Serrano C, Garcia-Estan J, Quesada T, Miras MT: Effect of diabetic hyperglycemia and other sugars on plasma dopamine-ß-hydroxilase activity. Diabetes 1984 , 33:1127-1132

38 Klegeris A, Budd TC, Greenfield SA: Acetylcholinesteraseinduced respiratory burst in macrophages: evidence for the involvement of the macrophage mannose-fucose receptor. Biochim Biophys Acta 1996, 1289:159-168

39 McNally AK, Anderson JM: Interleukin 4 induces foreign body giant cell giant cells from human monocytes/macrophages: differential lymphokine regulation of macrophage fusion leads to morphological variants of multinucleated giant cells. Am J Pathol 1995, 147:14871499

40 Schlesinger LS: Macrophage phagocytosis of virulent but not attenuated strains of Mycobacterium tuberculosis is mediated by mannose receptors in addition to complement receptors. J Immunol 1993, 150:2920-2930

41 Uccini S, Sirianni MC, Vincenzi L, Topino S, Stoppacacciaro A, Lesnoni La Parola I, Cerimele D, Cella $M$, Lanzavecchia A, Allavena $P$, Mantovani $A$, Baroni $C D$, Ruco LP: Kaposi's sarcoma cells express the macrophageassociated antigen mannose receptor and develop in peripheral blood cultures of Kaposi's sarcoma patients. Am J Pathol 1997; 150:929-938 


\title{
CHAPTER 6
}

\section{Lysine-based cluster mannosides that inhibit ligand binding to the human mannose receptor at nanomolar concentration.}

\author{
Erik A.L. Biessen ${ }^{\mathrm{a}}$, Femke Noorman ${ }^{\mathrm{b}}$, Marco E. van Teijlingen ${ }^{\mathrm{a}}$, \\ Johan Kuiper ${ }^{\mathrm{a}}$, Marrie Barrett-Bergshoeff ${ }^{\mathrm{b}}$, Martin K. Bijsterbosch ${ }^{\mathrm{a}}$, \\ Dingeman C. Rijken ${ }^{b}$, and Theo J.C. van Berkel'.
}

\footnotetext{
a)Division of Biopharmaceutics, Leiden/Amsterdam Center for Drug Research, University of Leiden, Leiden, The Netherlands.

')Gaubius Laboratory, TNO Prevention and Health, Leiden, The Netherlands
} 


\section{SUMMARY}

In search of synthetic high affinity ligands for the mannose receptor, we synthesized a series of lysinebased oligomannosides containing two $\left(M_{2} L\right)$ to six $\left(M_{6} L_{5}\right)$ terminal $\alpha$-D-mannose groups that are connected with the backbone by flexible elongated spacers $(16 \AA)$.

The synthesized cluster mannosides were all able to displace binding of biotinylated ribonuclease B and tissue-type plasminogen activator to isolated human mannose receptor. The affinity of these cluster mannosides for the mannose receptor was continuously enhanced from $18-23 \mu \mathrm{M}$ to $0.5-2.6 \mathrm{nM}$ with mannose valencies increasing from two to six. On average, expansion of the cluster mannoside with an additional $\alpha$-D-mannose group resulted in a 10 -fold increase in its affinity for the mannose receptor. $M_{3} L_{2}$ to $M_{6} L_{5}$ displayed negative cooperative inhibition of ligand binding to the mannose receptor, suggesting that binding of these mannosides involves multiple binding sites.

The nanomolar affinity of the most potent ligand, the hexamannoside $M_{6} L_{5}$ makes it the most potent synthetic cluster mannoside for the mannose receptor yet developed. As a result of its high affinity and accessible synthesis, $M_{6} L_{5}$ not only is a powerful tool to study the mechanism of ligand binding by the mannose receptor, but it is also a promising targeting device to accomplish cell-specific delivery of genes and drugs to liver endothelial cells or macrophages in bone marrow, lungs, spleen and atherosclerotic plaques.

\section{INTRODUCTION}

The mannose receptor is a $175-\mathrm{kDa}$ membrane-associated protein that is localized on sinusoidal liver cells, peripheral and bone marrow macrophages, and dendritic cells. ${ }^{1-4}$ It recognizes and internalizes mannosylated polysaccharides from pathological microorganisms, ${ }^{5}$ tumour cells, ${ }^{6}$ and yeast cells ${ }^{7}$ and glycoproteins like type-I procollagen, ${ }^{8}$ tissue-type plasminogen activator, ${ }^{9}$ or various lysosomal enzymes. ${ }^{10}$ As such, the mannose receptor participates in the nonimmune host-defence system. In addition, the macrophage receptor is implicated in major histocompatability complex-mediated antigen presentation by dendritic cells. ${ }^{11}$

The cDNA of the mannose receptor has been sequenced by Taylor et al. ${ }^{12}$ and codes for five types of domains ${ }^{13}$ : an $\mathrm{N}$-terminal cysteine-rich domain, a transmembrane domain, a fibronectin type II-like domain, a domain composed of eight strongly homologous repeats (the so-called carbohydrate recognition domains or CRDs) and a C-terminal cytoplasmic tail. Taylor and Drickamer have established that the CRDs are involved in ligand binding. ${ }^{13,14}$ Recent structure-function studies of recombinant truncated forms of the mannose receptor provided new insight into the mechanism of ligand binding by the mannose receptor. ${ }^{13,14}$ On basis of these results, it was proposed that CRD4 is the only CRD to display a monosaccharide specificity characteristic for the mannose receptor. ${ }^{15}$ CRD4 and CRD5 appear to be required for high affinity binding of high mannose-type glycoproteins and mannosylated bovine serum albumin (BSA). By contrast, at least five consecutive CRDs are needed for avid binding of highly mannosylated polysaccharides like mannan. ${ }^{14}$

Since each CRD embeds only a single mannose binding site, this implies that the mannose receptor may accommodate five to eight appropriately configured terminal $\alpha$-D-mannose residues. Previous studies by Hoppe et al. ${ }^{16}$ and Janssen et al. ${ }^{17}$ established that the affinity of mannosylated albumin for 
the mannose receptor indeed correlated with the extent of mannosylation. Surprisingly, derivatization with more than 22-24 mannose groups was required for high affinity recognition by the mannose receptor. This is considerably higher than the maximum number of CRDs thought to participate in ligand binding. On one hand the above finding may reflect a purely entropic phenomenon, caused by an increased chance of $\alpha$-D-mannose groups to be adequately configured with respect to each other. On the other hand, it may suggest that multiple receptor molecules cooperate in the ligand binding process.

To address this we have evaluated the effect of mannose valency on the affinity for the mannose receptor in close detail using a series of homologous cluster mannosides that possess two to six terminal $\alpha$-D-mannose groups. This study shows that recognition of low molecular weight mannosides by the mannose receptor is consistently, and not in a stepwise manner, enhanced with valencies increasing from two to six and thus provides new information on the process of ligand binding by the mannose receptor.

\title{
MATERIALS AND METHODS
}

\begin{abstract}
Materials
$\mathrm{Na}^{125} \mathrm{I}$ in $0.1 \mathrm{M} \mathrm{NaOH}(13.5 \mathrm{mCi} / \mu \mathrm{g})$ was purchased from Amersham (Buckinghamshire, United Kingdom). BSA (fraction $\mathrm{V}$, delipidated), collagenase (type I), p-nitro-phenolphosphate, p-aminophenyl- $\alpha$-D-mannopyranoside, and ribonuclease $B$ (bovine pancreas) were purchased from Sigma. L-Lysine-HCl; L-lysyl-L-lysine, $2 \mathrm{HCl} .0 .5 \mathrm{H}_{2} \mathrm{O}$; di-(L-lysyl)-L-lysine, $3 \mathrm{AcOH}$; tri-(L-lysyl)-L-|ysine, $4 \mathrm{AcOH}$; and tetra-(L-lysyl)-L-lysine, $5 \mathrm{AcOH}$ were all obtained from Bachem Feinchemikalien AG (Bubendorf, Switzerland). Thiophosgene was obtained from Aldrich Chemie (Bornem, Belgium). N,N-Dimethylformamide obtained from Merck (Hohenbrunn, Germany) was refluxed for $4 \mathrm{~h}$ with $\mathrm{CaH}_{2}$ (5 g/liter) and destilled under reduced pressure. Streptavidin-alkaline-phosphatase conjugate was from Amersham. Tissue-type plasminogen activator (t-PA) from a recombinant human melanoma cell culture was provided by Dr. J. Verheijen (Gaubius Laboratory, TNO-PG, Leiden, The Netherlands).
\end{abstract}

\section{Chromatography}

Thin layer chromatography was performed using silica $F_{254}$ preformed layers $(0.1 \mathrm{~mm})$ on a plastic backing (Schleicher \& Schuell $\mathrm{DC}-\mathrm{F} 1500)$ and $\mathrm{MeOH}(\mathrm{A})$, acetonitrile- $\mathrm{H}_{2} \mathrm{O}(80: 20, \mathrm{v} / \mathrm{V})(\mathrm{B})$, or $\mathrm{MeOH}-\mathrm{CH}_{3} \mathrm{Cl}(80: 20, \mathrm{~V} / \mathrm{V})(\mathrm{C})$ as eluent. Carbohydrates were visualized after spraying with $20 \% \mathrm{H}_{2} \mathrm{SO}_{4}$ in $\mathrm{MeOH}$ and subsequent heating at $140-160^{\circ} \mathrm{C}$. Amine- or amide-containing compounds were visualized after spraying with ninhydrin and subsequent heating at $140^{\circ} \mathrm{C}$, while compounds containing aromatic group were visualized by UV shadowing $(254 \mathrm{~nm}$ ). Preparative column chromatography was performed using Kieselgel 60 (Merck, Hohenbrunn, Germany).

\section{Instrumental analysis}

NMR spectra were recorded at $300 \mathrm{MHz}\left({ }^{\prime} \mathrm{H}\right)$ with a Bruker WM300 spectrometer operating in the Fourier Transform mode (FT). Chemical shifts are denoted in ppm $(\delta)$ relative to tetramethylsilane as internal standard. Mass spectra were obtained using a Finnigan MAT 900 mass spectrometer, using electrospray $\left(\mathrm{MeOH} / \mathrm{H}_{2} \mathrm{O}(80 / 20)+1 \% \mathrm{HAC}\right)$ as the ionization technique. Positive ions were visualized after data processing using the HMR BSCAN UP profile.

\section{Synthesis}

4-( $\alpha$-D-Mannopyranosyloxy)phenylisothiocyanate (1b) - Compound 1a (scheme 1) was converted into the phenyl isothiocyanate derivative (1b) as described by Monsigny et al. ${ }^{18}$ and Kataoka et al. ${ }^{19}$ In short, a mixture of compound $1 \mathrm{a}(244 \mathrm{mg}, 0.9 \mathrm{mmol})$ and thiophosgene $(0.52 \mathrm{~mL}, 5.1 \mathrm{mmol})$ in ethanol/ $\mathrm{H}_{2} \mathrm{O}(80: 20, \mathrm{v} / \mathrm{N} ; 50 \mathrm{~mL})$ was stirred for $2 \mathrm{~h}$ at room temperature. The excess of thiophosgene was removed by perspiration with $\mathrm{N}_{2}$ for $1 \mathrm{~h}$ at room temperature. After concentration of the solution under reduced pressure, the residue was dissolved in a small volume of distilled water $(1-2 \mathrm{ml})$, and $\mathrm{NaOH}(1.0 \mathrm{M})$ was added to $\mathrm{pH} 6.0$. The solution was concentrated, and the residue was chromatographed over a Kieselgel 60 column (40 ml) using $\mathrm{CH}_{2} \mathrm{Cl}_{2} / \mathrm{MeOH}(80: 20$, $\mathrm{V} / \mathrm{V}$ ) as eluent. Fractions containing product $1 \mathrm{~b}$ were pooled and lyophilized to yield $288 \mathrm{mg}$ of a white crystaline powder $(0.916 \mathrm{mmol}$; 102\%); $R_{F}: 0.75$ (B), 0.67 (C). Mass: 313.1 ( $\mathrm{M}^{+}$calculated: 313.32$) ;{ }^{13} \mathrm{C}-\mathrm{NMR}$ Attached Proton Test (APT):

161.3 (C ${ }_{1}$-phenyl), 138.5 (C ${ }_{4}$-phenyl), 127.8 ( $\mathrm{C}_{2}, 6$-phenyl), 118.9 ( $\mathrm{C}_{3}, 5$-phenyl), 101.1 (C $\mathrm{C}_{1}$ - Man, $\alpha$-configuration), 76.9 (C ${ }_{5}$-Man), 73.6 ( $C_{2}$-Man), 72.1 ( $C_{3}$-Man), 70.0 ( $C_{4}$-Man), 63.3 ( $C_{6}$-Man). 


\section{Mannosylated oligolysines}

Mannosylated (oligo)lysines, i.e. $\quad M_{2} L(2 a), \quad M_{3} L_{2}(2 b), M_{4} L_{3}(2 c), \quad M_{5} L_{4}(2 d)$ and $M_{6} L_{5}$ (2e) were synthesized according to the procedure of Jansen et al. ${ }^{17}$ with slight modifications. In general, compound $1 \mathrm{~b}(0.10 \mathrm{mmol} ; 32 \mathrm{mg})$ and (oligo)lysine $(0.83 \mathrm{molar}$ equivalents on the basis of the amino group content) were dissolved in a mixture of $0.1 \mathrm{M}$ sodium hydrogen carbonate $(\mathrm{pH} 8.5)$ and $\mathrm{N}, \mathrm{N}$-dimethylformamide $(50: 50, \mathrm{v} / \mathrm{v} ; 4 \mathrm{ml})$, and the solution was stirred for $18 \mathrm{~h}$ in the dark at room temperature. The progression of the reaction was monitored by TLC. In case all of compound $\mathbf{1 b}$ had reacted, while the reaction was not yet complete, an additional amount of $1 \mathrm{~b}$ ( 0.4 molar equivalents) was added, and the reaction mixture was incubated for another $8 \mathrm{~h}$. Subsequently, the mixture was concentrated in vacuo, and the crude products 2a-e were chromatographed over a Kieselgel 60 column using acetronitrile/ $\mathrm{H}_{2} \mathrm{O}$ $(80: 20, v / v)$ as eluent. Fractions containing product $2 a-e$ were pooled and lyophilized to yield a whitish powder.

$N^{2}, N^{6}-B i s\left[N-\left(p-(\alpha-D-m a n n o p y r a n o s y l o x y)\right.\right.$ anilino)thiocarbamyl]-L-lysine $\left(M_{2} L ; 2 a\right)$

$\mathrm{R}_{\mathrm{F}}=0.31(\mathrm{~A})$; yield: $5.2 \mu \mathrm{mol}(12.5 \%)$; Mass $\left(\mathrm{M}+\mathrm{Na}^{+}\right): 794.6\left(\mathrm{M}^{+}\right.$calculated: 771.5$) ;{ }^{1} \mathrm{H}-\mathrm{NMR}\left(\mathrm{D}_{2} \mathrm{O} / \mathrm{CD}_{3} \mathrm{OD}\right): \delta 1.27$ (q, br, $2 \mathrm{H}$, $\mathrm{CH}_{2}-\mathrm{Y}$ ), $1.63\left(\mathrm{q}, \mathrm{br}, 2 \mathrm{H}, \mathrm{CH}_{2}-\delta\right), 1.90\left(\mathrm{q}, \mathrm{br}, 2 \mathrm{H}, \mathrm{CH}_{2}-\beta\right), 3.50$ (t, br, $\left.2 \mathrm{H}, \mathrm{CH}_{2}-\epsilon\right), 3.75-4.13(\mathrm{~m}, 11 \mathrm{H}, \mathrm{Man} \mathrm{H}-1$ to $\mathrm{H}-5$ and $\mathrm{CH}-\alpha) ; 4.04$

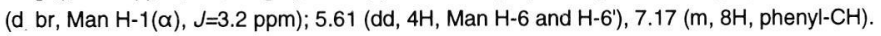

$N^{*}-\left[N^{6}, N^{6}-B i s\left[N-\left(p-(\alpha-D-m a n n o p y r a n o s y l o x y)\right.\right.\right.$ anilino)thiocarbamyl]-L-lysyl]- $N^{6}-[N-(p-(\alpha-D-m a n n o p y r a n o s y l o x y)$ anilino $)$ thiocarbamyl]L-lysine $\left(M_{3} L_{2}: 2 b\right)$. $R_{F}(A)=0.20$; yield: $11.1 \mu \mathrm{mol}(40 \%)$; Mass $\left(M+N^{+}\right): 1235.8\left(M^{+}\right.$calculated: 1212.8); ${ }^{H} H-N M R\left(D_{2} O / C_{3} O D\right): \delta$ 1.33 (q, $\left.4 \mathrm{H}, \mathrm{CH}_{2}-\gamma\right), 1.54$ (q, br, $\left.4 \mathrm{H}, \mathrm{CH}_{2}-\delta\right), 1.76$ (q, br, $\left.4 \mathrm{H}, \mathrm{CH}_{2}-\beta\right), 3.39$ (t, br, 4H, $\left.\mathrm{CH}_{2}-\epsilon\right), 3.73-4.19(\mathrm{~m}, 17 \mathrm{H}, \mathrm{Man} \mathrm{H}-1$ to $\mathrm{H}-5$ and $\mathrm{CH}-\alpha) ; 4.06$ (d, br, Man H-1( $\alpha$ ), J=3.1 ppm); 5.57 (dd, $6 \mathrm{H}$, Man H-6 and $\left.\mathrm{H}-6^{\prime}\right), 7.22(\mathrm{~m}, 12 \mathrm{H}$, phenyl-CH).

$N^{2}-\left[N^{2}-\left[N^{2}, N^{6}-B i s\left[N-(p-(\alpha-D-m a n n o p y r a n o s y l o x y)\right.\right.\right.$ anilino $)$ thiocarbamyl]-L-Lysyl] $-N^{6}-[N-(p-(\alpha-D-m a n n o p y r a n o s y l o x y)$ anilino $)-$ thiocarbamyl]-L-lysyl]- $N^{6}-\left[N-\left(p-\left(\alpha-D\right.\right.\right.$-mannopyranosyloxy)anilino)thiocarbamyl]-L-lysine $\left(M_{4} L_{3}: 2 c\right)$. $R_{F}(A): 0.11 ;$ yield: $7.0 \mu m o l$ (34\%); Mass $\left(\mathrm{M}+\mathrm{Na}^{+}\right): 1676.1\left(\mathrm{M}^{+}\right.$calculated 1654.1); ${ }^{1} \mathrm{H}-\mathrm{NMR}\left(\mathrm{D}_{2} \mathrm{O} / \mathrm{CD}_{3} \mathrm{OD}\right): \delta 1.26\left(\mathrm{q}, 6 \mathrm{H}, \mathrm{CH}_{2}-\mathrm{\gamma}\right), 1.57$ (q, br, $\left.6 \mathrm{H}, \mathrm{CH}_{2}-\delta\right), 1.90$ (q, $\left.6 \mathrm{H}, \mathrm{CH}_{2}-\beta\right), 3.31(\mathrm{t}, \mathrm{br}, 6 \mathrm{H}, \mathrm{CH}-\epsilon), 3.68-4.26(\mathrm{~m}, 23 \mathrm{H}, \mathrm{Man} \mathrm{H}-1$ to $\mathrm{H}-5$ and $\mathrm{CH}-\alpha), 3.97$ (d, br, Man H-1( $\alpha$ ), J=2.9 ppm); 5.52 (dd, $8 \mathrm{H}, \mathrm{Man} \mathrm{H}-6$ and $\left.\mathrm{H}-6^{\prime}\right), 7.05(\mathrm{~m}, 16 \mathrm{H}$, phenyl- $\mathrm{CH}$ )

$N^{2}-\left[N^{2}-\left[N^{2}-\left[N^{2}, N^{6}-B i s\left[N-(p-(\alpha-D-m a n n o p y r a n o s y l o x y)\right.\right.\right.\right.$ anilino $)$ thiocarbamyl]-L-lysyl] $-N^{6}-[N-(p-(\alpha-D-$ mannopyranosyloxy $)$ anilino $)$ thiocarbamyl]-L-lysyl]- $N^{6}-\left[N-(p-(\alpha-D-m a n n o p y r a n o s y l o x y)\right.$ anilino $)$ thiocarbamyl]-L-lysyl]- $N^{6}-[N-(p-(\alpha-D-m a n n o p y r a n o s y l-o x y)$ anilino $)$ thiocarbamyl]-L-lysine $\left(M_{5} L_{4}: 2 d\right)$. $R_{F}(A): 0.05$; Yield: $11.5 \mu \mathrm{mol}(50 \%)$; Mass $\left(1 / 2 \cdot \mathrm{M}^{2+}+\mathrm{Na}^{+}\right): 1072.6\left(\mathrm{M}{ }^{+}\right.$calculated: 2095.4$) ;{ }^{1} \mathrm{H}-$ NMR $\left(\mathrm{D}_{2} \mathrm{O} / \mathrm{CD}_{3} \mathrm{OD}\right)$ : $\delta 1.38$ (q, br, $\left.8 \mathrm{H}, \mathrm{CH}_{2}-\mathrm{Y}\right), 1.75$ (q, br, 8H, $\left.\mathrm{CH}_{2}-\delta\right), 1.88$ (q, 8H, $\left.\mathrm{CH}_{2}-\beta\right), 3.34$ (t, br, 8H, CH $\left.{ }_{2}-\epsilon\right), 3.66-4.36(\mathrm{~m}$,

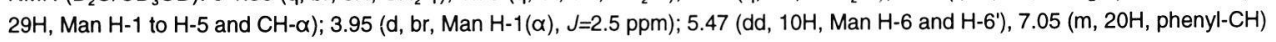

$N^{2}-\left[N^{2}-\left[N^{2}-\left[N^{2}-\left[N^{2}, N^{6}-B i s\left[N-\left(p-\left(\alpha-D-\right.\right.\right.\right.\right.\right.\right.$ mannopyranosyloxy)anilino)thiocarbamyl]-L-lysyl]- $N^{6}-[N-(p-(\alpha-D-m a n n o p y r a n o s y l o x y)$ anilino $)$ thiocarbamyl]-L-lysyl]- $N^{6}-\left[N-(p-(\alpha-D-m a n n o-p y r a n o s y l o x y)\right.$ anilino $)$ thiocarbamyl]-L-lysyl]- $N^{6}-[N-(p-(\alpha-D-m a n n o-p y r a n o s y l o x y)$ anilino)thio-carbamyl]-L-lysyl]- $N^{6}-\left[N-\left(p-(\alpha-D-m a n n o p y r a n o s y l-o x y)\right.\right.$-anilino)thiocarbamyl]-L-lysine $\left(M_{6} L_{5} ; 2 e\right)$. $R_{F}(A): 0.05 ;$ yield: $11.5 \mu \mathrm{mol}$ (83\%); Mass $\left(1 / 2{ }^{*} \mathrm{M}^{2+}+\mathrm{Na}^{+}\right)$: $1291.3\left(\mathrm{M}^{+}\right.$calculated: 2536.7$) ;{ }^{1} \mathrm{H}-\mathrm{NMR}\left(\mathrm{D}_{2} \mathrm{O} / \mathrm{CD}_{3} \mathrm{OD}\right)$ : $\delta 1.32\left(\mathrm{q}, \mathrm{br}, 8 \mathrm{H}, \mathrm{CH}_{2}-\mathrm{v}\right), 1.52\left(\mathrm{q}, \mathrm{br}, 8 \mathrm{H}, \mathrm{CH}_{2}{ }^{-}\right.$

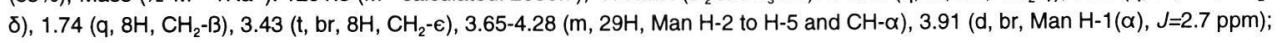
4.32 (dd, $10 \mathrm{H}$, Man $\mathrm{H}-6$ and $\left.\mathrm{H}-6^{\prime}\right), 7.06-7.10(\mathrm{~m}, 2 \mathrm{H}$, phenyl- $\mathrm{CH})$.

\section{Biotinylation or radio-iodination of $t-P A$ and ribonuclease $B$}

Ribonuclease $\mathrm{B}$ or t-PA were dialyzed against $0.1 \mathrm{M} \mathrm{NaHCO}_{3}, \mathrm{pH} 8.5$, and subsequently incubated for 3 h at room temperature with N-hydroxysuccinimide-activated biotin (Zymed Laboratories Inc., South San Francisco, CA) at a ratio of 1 mol of protein to $6 \mathrm{~mol}$ of $\mathrm{N}$-hydroxysuccinimide-activated biotin for ribonuclease $\mathrm{B}$, and $200 \mathrm{~mol}$ of of $\mathrm{N}$-hydroxysuccinimide-activated biotin for t-PA, respectively. After reaction, the protein was dialyzed against $20 \mathrm{mM} \mathrm{Tris} / \mathrm{HCl}$ buffer, $\mathrm{pH} 7.4$, containing $150 \mathrm{mM} \mathrm{NaCl}, 5 \mathrm{mM} \mathrm{CaCl}$ and $0.5 \%(\mathrm{v} / \mathrm{V})$ Tween-80. t-PA was radioiodinated by the IODO-GEN method as described, and a specific radioactivity of 3500-5000 $\mathrm{cpm} / \mathrm{ng}$ of protein was obtained. ${ }^{20}$

\section{Isolation of endothelial liver cells.}

Rat endothelial liver cells were isolated by a collagenase perfusion protocol at $37^{\circ} \mathrm{C}$ as described previously. ${ }^{21}$ Liver cells were separated by differential centrifugation and endothelial cells were subsequently purified by counterflow centrifugation. The purity of endothelial cells as monitored by peroxidase staining was at least $95 \%$. Viability of the cells used for in vitro experiments as judged by $0.2 \%$ trypan blue exclusion.

\section{Isolation of human mannose receptor}

Human mannose receptor was isolated from human placenta after solubilisation with Triton $X-100$ and subsequent affinity chromatography over mannosylated albumin-sepharose according to Otter et al. ${ }^{22}$ 


\begin{abstract}
Mannose receptor binding assay
Displacement studies of binding of biotinylated ribonuclease B and biotinylated t-PA to isolated human mannose receptor were performed essentially as described by Otter et al. ${ }^{9}$ Activated PVC multiwell plates (Flow Laboratories) were coated overnight at $4^{\circ} \mathrm{C}$ with purified mannose receptor $( \pm 15 \mathrm{ng} /$ well) in coating buffer $(100 \mu \mathrm{l} ; \mathrm{pH} 7.4)$, containing $20 \mathrm{mM} \mathrm{Tris/HCl}, 150 \mathrm{mM} \mathrm{NaCl}, 5 \mathrm{mM}$ $\mathrm{CaCl}_{2}$. After washing, the wells were incubated for $30 \mathrm{~min}$ at $20^{\circ} \mathrm{C}$ with assay buffer (coating buffer supplemented with $0.5 \%$ Tween 80 and $0.1 \% \mathrm{BSA})(125 \mu \mathrm{ll})$ to minimize aspecific ligand binding. Then the wells were washed and preincubated for $30 \mathrm{~min}$ at $20^{\circ} \mathrm{C}$ with a solution of $\alpha$-D-mannose $(10 \mu \mathrm{M}-100 \mathrm{mM})$ or one of the cluster mannosides $(1 \mathrm{nM}-2 \mathrm{mM})$ in assay buffer $(100 \mu \mathrm{l})$. Biotinylated ribonuclease $\mathrm{B}$ or biotinylated t-PA in assay buffer was added to a final concentration of 580 and $1.3 \mathrm{nM}$, respectively, and the mixture was incubated for $2 \mathrm{~h}$ at $20^{\circ} \mathrm{C}$. After a washing step, the wells were incubated for $1 \mathrm{~h}$ at room temperature with streptavidinalkaline phosphatase conjugate (1:1000 dilution in assay buffer; $100 \mu \mathrm{l})$. p-Nitrophenolphosphate $(1 \mathrm{mg} / \mathrm{ml} ; 100 \mu \mathrm{l}$ in a $100 \mathrm{mM}$ diethanolamine, $5 \mathrm{mM} \mathrm{MgCl}_{2}$-buffer, $\mathrm{pH}$ 9.5) was added after thorough rinsing of the wells. The plate was incubated for $4 \mathrm{~h}$ at $25^{\circ} \mathrm{C}$ during which the $\triangle \mathrm{A} 405 \mathrm{~h}$ was determined as a measure of ligand binding. Uncoated wells were used as a control for aspecific adherence of biotinylated ribonuclease $B$ or biotinylated t-PA to the wells.
\end{abstract}

\title{
Competition studies of ${ }^{125}$-t-PA binding to endothelial liver cells
}

Competition studies of ${ }^{125} \mathrm{I}-\mathrm{t}-\mathrm{PA}$ binding to endothelial liver cells were performed as described before. ${ }^{23}$ Endothelial cells (2א10 ; $150 \mu \mathrm{g}$ of cell protein), in Dulbecco's modified Eagle's medium (DMEM, $0.5 \mathrm{ml}$ ), containing $2 \%(\mathrm{w} / \mathrm{v})$ BSA and ${ }^{125} \mathrm{l}-\mathrm{t}-\mathrm{PA}(1 \mathrm{nM})$, were incubated for $2 \mathrm{~h}$ at $4^{\circ} \mathrm{C}$ with a variable concentration of unlabeled biotinylated t-PA (bio-t-PA), biotinylated Ribo-B (bio-Ribo B) or $M_{6} L_{5}$ ranging from $0.1 \mathrm{nM}$ to $20 \mu \mathrm{M}$. Following incubation, cells were washed twice with DMEM+0.2\% BSA and once with DMEM, and the cell-associated radioactivity was counted. Nonspecific binding was defined as ${ }^{125}$-t-PA binding in the presence of $100 \mathrm{mM} \alpha$ D-mannose. Cell-bound radioactivity was determined using a Packard $y$-counter and corrected for protein content.

\section{Data analysis}

To calculate the $\mathrm{IC}_{50}$ values and Hill coefficients $\left(n_{H}\right)$, the displacement binding data were analyzed according to the following binding model: percentage of specific binding $=100 /\left(1+\left((\right.\right.$ displacer $\left.) / I_{50}{ }^{n+}\right)$ using a computerized nonlinear fitting program (Prism, ISI software; Ref. 24). As a measure of the actual affinity for the mannose receptor, apparent inhibition constants (dissociation constants) were calculated from the $I C_{50}$ values using the equation $K_{i \text { (app) }}=I C_{5 d} /\left(1+(\right.$ Ligand $\left.) / K_{d}\right)$, and using $K_{d}$ values for bio-tinylated ribonuclease $B$ and $\mathrm{t}-\mathrm{PA}$ obtained from the saturation binding studies ( 550 and $1.66 \mathrm{nM}$, respectively). The irregular competition curves of $\alpha$-D-mannose were also fitted according to a two-site mixed stimulation/inhibition model (percentage specific binding $=\left(100+\right.$ percentage maximal stimulation $\times\left(1-1 /(1+\right.$ (displacer $\left.\left.\left.) / \mathrm{SC}_{50}\right)\right)\right) /\left(1+(\right.$ displacer $\left.) / \mathrm{IC}_{50}\right), \mathrm{SC}_{50}$ being the concentration at which half maximal stimulation of ligand binding to the mannose receptor is attained. The significance of the differences between means was tested by unpaired two-way Student's-t test.

\section{RESULTS}

\section{Synthesis of the cluster mannosides}

The cluster mannosides were prepared by a two-step synthetic procedure. First, 4-aminophenyl- $\alpha$-Dmannopyranoside (1a) was quantitatively converted into 4-( $\alpha$-D-mannopyranosyloxy)phenylisothiocyanate using thiophosgene (1b). Second, the activated $\alpha$-D-mannopyranoside $\mathbf{1 b}$ was reacted with a series of oligolysines, i.e. mono-, di-, tri-, tetra- and pentalysine. Progression of the coupling was monitored on TLC by ninhydrin staining. The reaction was considered to be complete when no significant ninhydrin-positive spots, indicative of unreacted amino groups, could be detected. Subsequent chromatography of the crude reaction mixture over Kieselgel 60 and lyophilization afforded product $2 a-e$ as white crystalline powders at yields ranging from 34 to $83 \%$. TLC analysis (UV, ninhydrin, sulphuric acid detection) confirmed that the isolated products $2 a-e$ were fully mannosylated, did not contain any free amino groups and were apparently pure. ${ }^{1} \mathrm{H}-\mathrm{NMR}$ and mass spectrometry of the isolated products $2 a-2 e$ were in agreement with the chemical structure of the anticipated products $M_{2} L$, $M_{3} L_{2}, M_{4} L_{3}, M_{5} L_{4}$ and $M_{6} L_{5}$ (for chemical structures see Fig 1). 


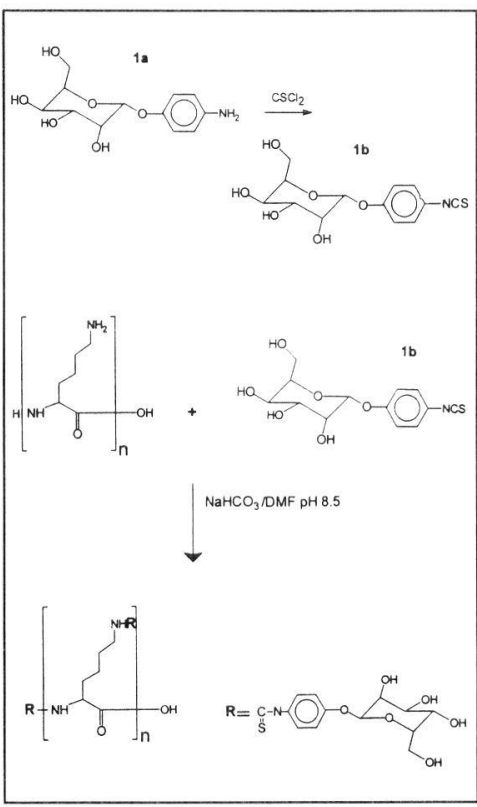

Scheme 1 Reaction scheme of the synthesis of clustermannosides $2 \mathrm{a}$ to $2 \mathrm{e}$. $2 a, n=1 ; 2 b, n=2,2 c, n=3 ; 2 d, n=4 ; 2 e, n=5$.

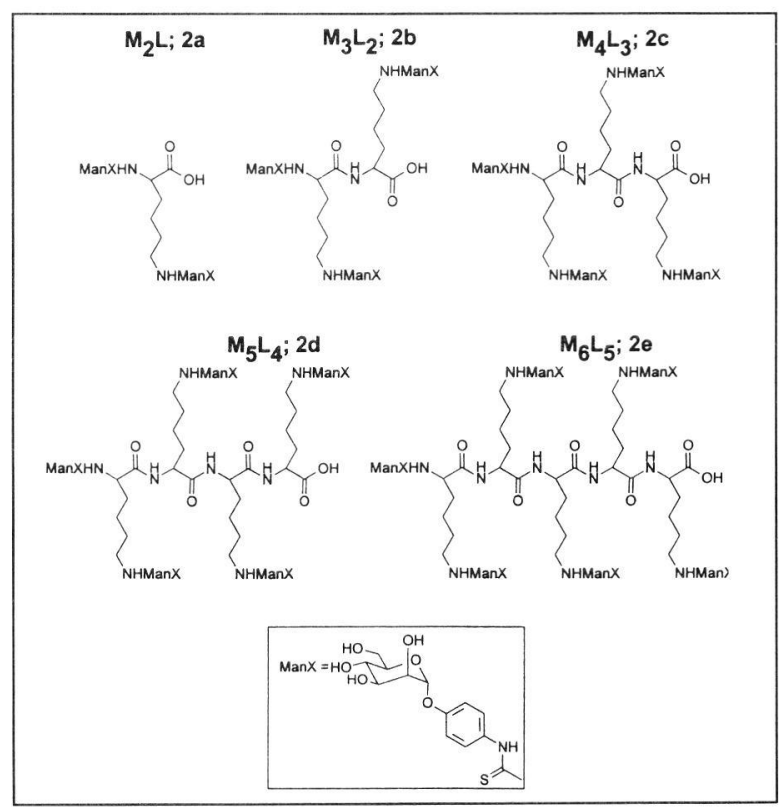

Fig 1 Chemical structures of the cluster mannosides $2 \mathrm{a}$ to $2 \mathrm{e}$.

\section{Competition binding studies}

First we have performed saturation studies of bio-Ribo $B$ and bio-t-PA binding to the isolated mannose receptor in the enzyme-linked receptor sorbent assay described by Otter et al. ${ }^{9}$ and Barrett-Bergshoeff et al. ${ }^{25}$ ( Fig 2). Bio-Ribo B and bio-t-PA binding appears to be saturable $(0.354 \pm 0.006 \Delta \mathrm{A} / \mathrm{hr}$ and 0.305 $\pm 0.003 \triangle \mathrm{A} / \mathrm{hr}$, respectively) and obeyed classical law of mass action kinetics. The maximal binding capacity of bio-Ribo $\mathrm{B}$ and bio-t-PA were comparable. Analysis of the binding curves gave dissociation constants of $550 \pm 70 \mathrm{nM}$ for bio-Ribo $\mathrm{B}$ and $1.66 \pm 0.05 \mathrm{nM}$ for bio-t-PA. Hill coefficients were calculated to be close to unity ( $1.16 \pm 0.43$ and $1.13 \pm 0.03$, respectively), indicative of ligand binding to a single binding site.

Subsequently, competition studies of bio-Ribo B binding were performed for the synthesized mannosides. As can be seen from Fig 3A, all of the tested mannosides were able to completely inhibit the specific binding of bio-Ribo $B$ to the isolated human mannose receptor. The potency of the compounds to inhibit bio-Ribo $B$ binding was significantly increased with increasing mannose valency. The apparent inhibition constant $K_{i \text { ( app ) }}$ of $\alpha$-D-mannose was at least $10^{6}$-fold higher than that of the hexamannoside $\mathrm{M}_{6} \mathrm{~L}_{5}$, the most potent ligand in this study (2.7 mM and $2.6 \mathrm{nM}$, respectively, Table 1). Even the dimannoside $M_{2} L$ possessed a considerably higher affinity $\left(K_{i}\right.$ ( app) $=17.5 \mu M$ ) than $\alpha$ D-mannose. 
Fig 2

Saturation curve of bio-Ribo-B binding (A) and bio-t-PA (B) binding to isolated human mannose receptor in a receptor sorbent assay.

Multiwells, coated with isolated human mannose receptor, were incubated for $2 \mathrm{~h}$ at $20^{\circ} \mathrm{C}$ with a variable concentration of biotinylated ribonuclease $\mathrm{B}$ or biotinylated t-PA. After incubation, ligand binding was determined as described under "Materials and Methods". Specific binding of bio-Ribo B and bio-t-PA is plotted as $\triangle \mathrm{A} / \mathrm{h}$ and is corrected for aspecific binding determined in the presence of uncoated wells. The saturation binding curves were fitted using computerized nonlinear regression procedures.
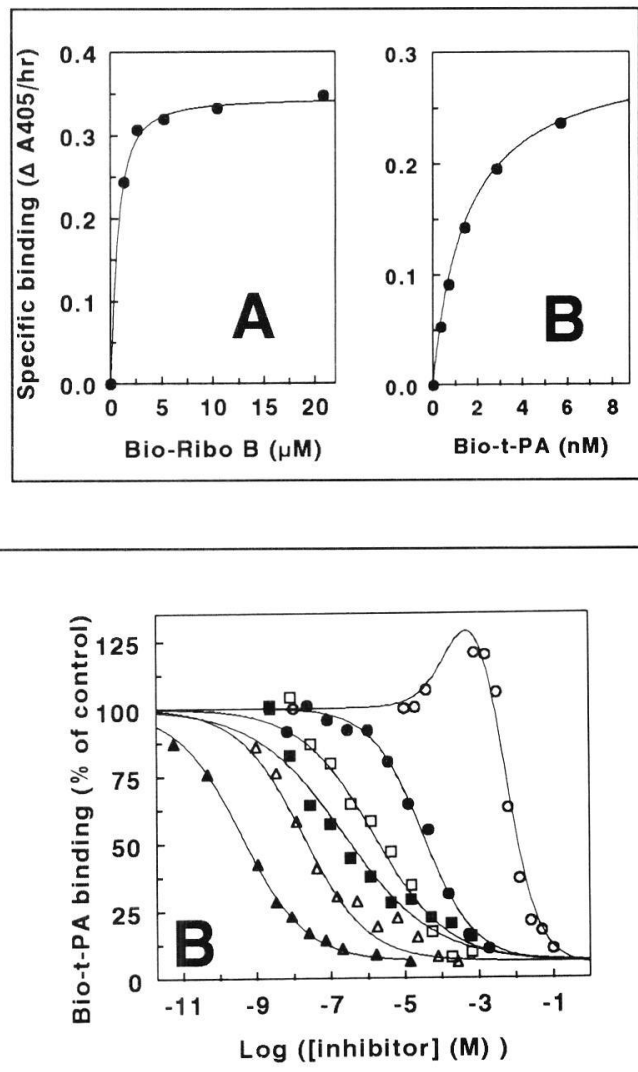

Fig 3 Competition studies of binding of biotinylated ribonuclease $B(A)$ or biotinylated t-PA $(B)$ to the isolated human mannose receptor by the following mannosides: $\alpha$-D-mannose (O); $\quad M_{2} L(\bullet) ; \quad M_{3} L_{2}(\square) ; \quad M_{4} L_{3}(\square) ; \quad M_{5} L_{4}(\Delta)$ and $M_{6} L_{5}(\mathbf{\Delta})$.

Multiwells, coated with isolated human mannose receptor, were incubated for $2 \mathrm{~h}$ at $20^{\circ} \mathrm{C}$ with a fixed concentration of biotinylated ribonuclease $B(580 \mathrm{nM})$ or biotinylated t-PA $(1.3 \mathrm{nM})$ in the absence or presence of displacer, at concentrations ranging from $10^{-10}$ to $10^{-1} \mathrm{M}$. After incubation, ligand binding was determined as described under "Materials and Methods". Total binding of bio-Ribo B and bio-t-PA is plotted as percentage of the control (without displacer) versus the log of the displacer concentration (in $M$ ). The inhibition curves for $\alpha$-D-mannose, $M_{2} L, M_{3} L_{2}, M_{4} L_{3}, M_{5} L_{4}$, and $M_{6} L_{5}$ were fitted using computerized nonlinear regression procedures.

To verify that the cluster mannosides inhibited bio-Ribo $\mathrm{B}$ binding in a competitive fashion by blocking the mannose binding site on the mannose receptor rather than by directly interfering with bio-Ribo $B$ itself, competition studies were also performed using another ligand for the human mannose receptor, biotinylated tissue-type plasminogen activator (bio-t-PA) ${ }^{22}$ ( Fig3B). In data not shown here it was demonstrated that bio-t-PA binding to the mannose receptor was fully inhibited in a competitive fashion by ribonuclease $B$, indicating that both ligands interact with the same binding site on the mannose receptor. 
Tabel 1 Affinity of the cluster mannosides as determined from competition studies of binding of blotinylated ribonuclease $\mathrm{B}$ or $\mathrm{t}-\mathrm{PA}$ to the isolated mannose receptor.

$-L o g\left(I C_{50}\right)$ values ( \pm S.D.) and $K_{i(\text { app })}$ values were calculated from the displacement curves using nonlinear regression analysis.

\begin{tabular}{|c|c|c|c|c|}
\hline \multirow[t]{2}{*}{ Compound } & \multicolumn{2}{|c|}{ Bio-Ribo B } & \multicolumn{2}{|c|}{ Blo-t-PA } \\
\hline & $-\log \left(I C_{50}\right)( \pm S . D)$. & $K_{1(\text { app })}(n M)$ & $-\log \left(I C_{50}\right)( \pm S . D)$. & $\left(K_{1 \text { (app) }}(n M)\right.$ \\
\hline$\alpha$-D-mannose & $2.00( \pm 0.04)$ & $2,700,000$ & $1.98( \pm 0.04)$ & $2,800,000$ \\
\hline $\mathrm{M}_{2} \mathrm{~L}$ & $4.49( \pm 0.07)$ & 17,500 & $4.38( \pm 0.07)$ & 22,600 \\
\hline $\mathrm{M}_{3} \mathrm{~L}_{2}$ & $5.76( \pm 0.10)$ & 950 & $5.43( \pm 0.09)$ & 2020 \\
\hline$M_{4} L_{3}$ & $6.61( \pm 0.15)$ & 135 & $6.30( \pm 0.09)$ & 270 \\
\hline $\mathrm{M}_{5} \mathrm{~L}_{4}$ & $7.56( \pm 0.08)$ & 15.1 & $7.78( \pm 0.07)$ & 8.9 \\
\hline $\mathrm{M}_{6} \mathrm{~L}_{5}$ & $8.33( \pm 0.09)$ & 2.6 & $9.05( \pm 0.09)$ & 0.5 \\
\hline
\end{tabular}

The bio-t-PA competition curves clearly demonstrated that the potency of the cluster mannosides to inhibit bio-t-PA binding was analogously increased with increasing mannose valency. $\left(K_{i}\right.$ (app) values calculated from the bio-t-PA competition curves ranged from $2.8 \mathrm{mM}$ for $\alpha$-D-mannose to $8.9 \mathrm{nM}$ for $M_{5} L_{4}$ and $0.5 \mathrm{nM}$ for $M_{6} L_{5}$. This is illustrated in Fig 4 in which $-\log \left(I_{50}\right)$ values of the mannosides from the bio-Ribo $B$ assay are plotted against those from the bio-t-PA assay. Clearly, the affinities in both assays correlate excellently (correlation coefficient $0.984 ; P<0.0001$; slope $1.11 \pm 0.07$ ).

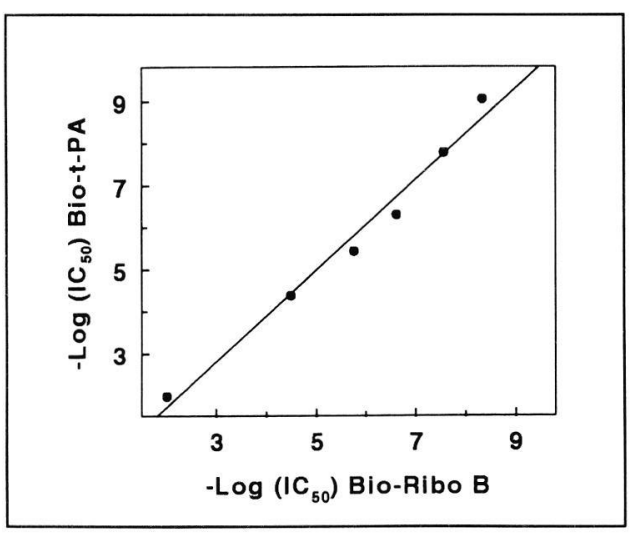

Fig 4 Correlation between the potency of the mannosides to inhibit bio-t-PA and ribonuclease $B$ binding to the isolated mannose receptor.

The inhibitory potencies of the cluster mannosides are derived from the data in Table 1 and are expressed as $-\log \left(\mid C_{50}\right) \pm$ S.D. Invisible error bars indicate errors smaller than the symbol size. $r=0.984$, slope $=1.11 \pm 0.07$.

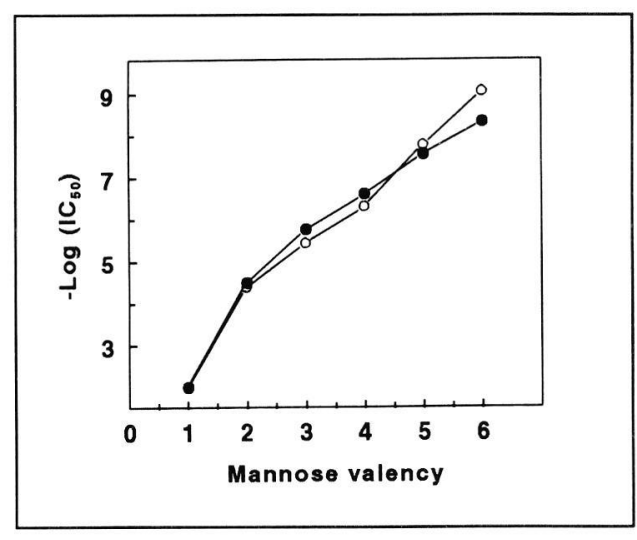

Fig 5 Effect of the mannose valency on the potency of cluster mannosides to inhibit binding of biotinylated ribonuclease $B(\bullet)$ or t-PA $(O)$ to isolated human mannose receptor.

Inhibitory potencies of the cluster mannosides are derived from the data in Table 1 and are expressed as $-\log \left(I_{50}\right) \pm$ S.D. Invisible error bars indicate errors smaller than the symbol size. 
Fig 5 shows that there is only a minor tendency of the $-\log \left(\mathrm{IC}_{50}\right)$ values to level off at high mannose valencies, suggesting that the cluster mannosides did not yet reach the theoretical maximum affinity. Moreover, the increase in affinity is steady and intermediate plateau values for the cluster mannosides were not observed.

To calibrate the receptor sorbent assay, competition studies of ${ }^{125}$-t-PA binding to endothelial liver cells were performed for $M_{6} L_{5}$, bio-t-PA and bio-Ribo B. All three tested ligands were able to inhibit ${ }^{125} \mathrm{I}-\mathrm{t}-\mathrm{PA}$ binding (Fig 6) at inhibition constants that were congruent to those found in the receptor sorbent assay $\left(\mathrm{K}_{\mathrm{i} \text { ( app })}=1.7 \pm 0.2 \mathrm{nM}, 3.4 \pm 0.4 \mathrm{nM}\right.$, and $190 \pm 70 \mathrm{nM}$, respectively). This further substantiates the validity of $K_{i(\text { app ) }}$ values derived from this receptor sorbent assay.

Interestingly, displacement of bio-Ribo B and bio-t-PA binding to the human mannose receptor by the mannosides was not monophasic, as judged from the low Hill coefficients of $M_{3} L_{2}, \quad M_{4} L_{3}, \quad M_{5} L_{4}$, and $M_{6} L_{5} \quad\left(n_{H}=0.4-0.5\right) \quad(F i g)$. In contrast, saturation curves of bio-Ribo $B$ and bio-t-PA binding to isolated mannose receptor proceeded in a purely competitive fashion $\left(n_{H}=1.16 \pm 0.43\right.$ and 1.17 \pm 0.02 , respectively). In both assays, the bivalent mannoside $M_{2} L$ exhibited an intermediate Hill coefficient of $0.63 \pm 0.05$ (bio-Ribo B) and $0.85 \pm 0.1$ (bio-t-PA). The Hill coefficients of both ligand binding assays correlated significantly $\left(r^{2}=0.990\right.$, slope $\left.1.006 \pm 0.05 ; P<0.0002\right)$. Competition curves of $\alpha$-D-mannose were clearly irregular. $\alpha$-D-mannose appeared to stimulate ligand binding to the mannose receptor by $\pm 25 \%$ at concentrations ranging from 30 to $300 \mu \mathrm{M}$. At higher concentrations, $\alpha$ $D$-mannose inhibited binding in a positive cooperative fashion with Hill coefficients of $2.1 \pm 0.5$ (bio-Ribo B) and $2.2 \pm 0.6$ (bio-t-PA).

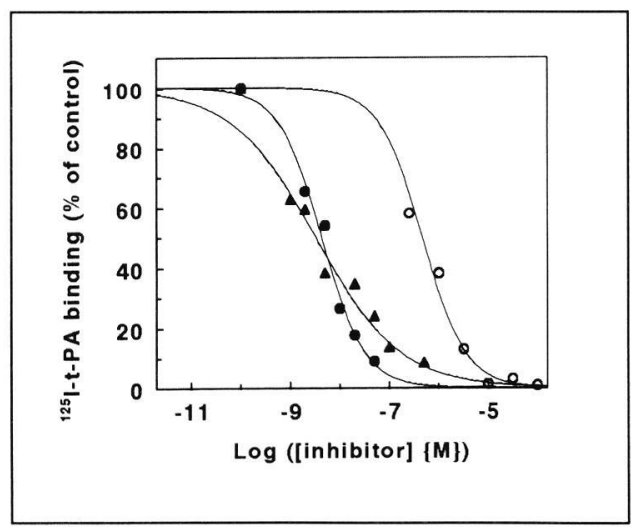

Fig 6 Competition studies of ${ }^{125}$-t-PA binding to endothelial liver cells by bio-Ribo B (O); bio-t-PA (๑); and $M_{6} L_{5}(\Delta)$.

Rat endothelial liver cells $\left(2 \times 10^{6} ; 150 \mu \mathrm{g}\right.$ of cell protein), in $\operatorname{DMEM}(0.5 \mathrm{ml})$, containing $2 \%(\mathrm{w} / \mathrm{v}) \mathrm{BSA}$ and ${ }^{125} \mathrm{l}-\mathrm{t}-\mathrm{PA}(1 \mathrm{nM})$, were incubated for $2 \mathrm{~h}$ at $4^{\circ} \mathrm{C}$ with a variable concentration of displacer. Following incubation, cells were washed twice with DMEM, $0.2 \%$ BSA and once with DMEM, and cell-associated radioactivity was counted. Nonspecific binding is defined as ${ }^{125}$ $\mathrm{t}-\mathrm{PA}$ binding in the presence of $100 \mathrm{mM} \alpha$-D-mannose.

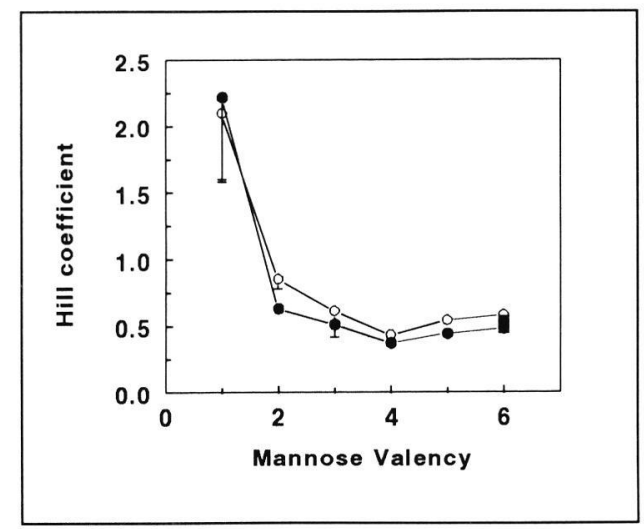

Fig 7 Effect of the valency of the (cluster) mannosides on the Hill coefficient of bio-Ribo $B(\bullet)$, bio-t-PA $(O)$ and ${ }^{125}$ t-PA (四).

Hill coefficients were calculated from the displacement curves in Figs. 3,4 by nonlinear regression analysis as described under "Materials and Methods". 
Competition studies of 4-aminophenyl $\alpha$-D-mannopyranoside also gave a 33\% stimulation combined with a positive cooperative inhibition ( $n_{H}=1.96 \pm 0.143$; data not shown). Since the stimulatory effect and the high apparent Hill coefficients were found in both receptor sorbent assays and in the endothelial cell binding assay $\left(\mathrm{M}_{6} \mathrm{~L}\right)$, we assume that it did not involve an artefact. Nonlinear regression analysis according to a two-site mixed stimulation/inhibition model showed that $\alpha$-D-mannose induced a maximal stimulation of bio-Ribo $B$ and bio-t-PA binding of $53 \%$ and $58 \%$, respectively, at low concentrations. Half maximal stimulation of ligand binding to the mannose receptor was attained at $250 \mu \mathrm{M}\left(-\log \left(\mathrm{SC}_{50}\right)=3.6\right.$ $\pm 0.2)$ and $400 \mu \mathrm{M}\left(-\log \left(\mathrm{SC}_{50}\right)=3.4 \pm 0.2\right)$, respectively. Full inhibition of ligand binding was attained at a $-\log \left(I C_{50}\right)$ of $2.00 \pm 0.05$ and $1.98 \pm 0.04$, resp. The above mixed stimulation/inhibition model excellently predicted the observed steep inhibition curve for $\alpha$-D-mannose.

\section{DISCUSSION}

In this study we have investigated the effect of the mannose valency of a cluster mannoside on its affinity for the mannose receptor. The ability of cluster mannosides to inhibit the binding of Ribo B, an established mannose receptor ligand, ${ }^{1}$ to the isolated human mannose receptor was determined in a receptor sorbent binding assay. Previous studies by Otter et al. ${ }^{9,25}$ have established that this assay provides a reliable estimate of the affinity of monosaccharides, proteins with high mannose-type glycosides, and mannosylated neoglycoproteins for the mannose receptor. The validity of the receptor sorbent assay was further documented by the finding that the $K_{d}$ for bio-Ribo- $B(550 \pm 70 \mathrm{nM})$ and bio-tPA $(1.66 \pm 0.05 \mathrm{nM})$ in the receptor sorbent assay paralleled $\mathrm{K}_{\mathrm{i}}$ values derived from competition studies of ${ }^{125}$ I-t-PA binding to endothelial liver cells $(190 \pm 70 \mu \mathrm{M}$, and $3.4 \pm 0.4 \mathrm{nM}$, respectively).

The competition studies showed that all mannosides were able to inhibit bio-Ribo B binding to the isolated mannose receptor. The affinity of the synthesized mannosides was strongly and consistently enhanced with increasing mannose valency. Since the apparent inhibition constants $K_{i}$ (ap) in the bioRibo $B$ and bio-t-PA binding assays were essentially equal and ribonuclease $B$ inhibits bio-t-PA binding in a competitive fashion, we may assume that inhibition of bio-Ribo $B$ binding by mannosides reflects competition for ligand binding to the mannose receptor. In addition, it suggests that binding data from the bio-Ribo $B$ assay are not significantly perturbed by heterogenicity of the sugar moiety from bio-Ribo $B$. The most complex mannosides from this study, $M_{5} L_{4}(2 d)$ and $M_{6} L_{5}(2 e)$ displayed nanomolar affinities for the mannose receptor, which are at least comparable to those of mannosylated albumin, ${ }^{16}$ mannosylated poly-L-lysine ${ }^{26,27}$ or endogenous glycoproteins such as t-PA. ${ }^{9}$ Competition studies of ${ }^{125}$ I-tPA binding to endothelial liver cells confirmed the nanomolar affinity of $M_{6} L_{5}$. Previous efforts to synthesize low molecular weight ligands for the mannose receptor yielded compounds with 1000 -fold lower, micromolar, affinities for the mannose receptor. ${ }^{15,28,29}$ Oshimi et al. demonstrated that the affinity of tris(hydroxymethyl) based mannosides was only slightly higher than that of bi- and monosubstituted analogues, which was attributed to the suboptimal valency and spacing of the terminal mannosyl groups $(\approx 9 \AA)$ within the mannose clusters. ${ }^{28}$ The di-, tri- and tetramannosides synthesized by Robbins et al. ${ }^{29}$ displayed higher, yet micromolar, affinities for the mannose receptor. Since the latter mannosides contained the same oligolysine backbone as our mannosides, their lower affinity is probably caused by differences in the chemical nature and the length of the spacers connecting the terminal $\alpha$-D-mannose groups with the lysine backbone. In theory, the phenyl group of the ( $p$-hydroxyanilino)carbamide spacer used in this study may contribute to ligand binding through $\Pi-\Pi$ interaction forces. ${ }^{30}$ Since preliminary binding studies revealed that the affinity of 4-aminophenyl- $\alpha$-D-mannopyranoside is only slightly higher than that of $\alpha$-D-mannose $\left(K_{i(\text { app })}=1.8 \mathrm{mM}, \log \left(I C_{50}\right)=-2.48 \pm 0.01\right.$, ; data not shown), we assume this 
to be unlikely. An alternative explanation is that the (p-hydroxyanilino)carbamide spacer is longer $(2 \AA)$ than the thioproprionyl spacer used by Robbins et al. ${ }^{29}$ Recent studies by Biessen et al. ${ }^{31}$ have already emphasized the relevance of optimal spacing of terminal glycosides to achieve avid recognition by a comparable eukaryotic lectin, the asialoglycoprotein receptor.

The $\left(\Delta G^{\circ}\right)_{\text {binding }}$ from $M_{2} L$, calculated from the logarithm of the $K_{i(\text { app ), }}$ is almost twice as large as that for $\alpha$-D-mannose $(-24.4 \mathrm{~kJ} / \mathrm{mol}$ and $-13.3 \mathrm{~kJ} / \mathrm{mol}$, resp.). In the case of competitive inhibition, this suggests that both mannose groups from $M_{2} L$ participate similarly in the binding process. The binding energy for $M_{6} L_{5}(-45 \mathrm{~kJ} / \mathrm{mol})$ is, in turn, twofold higher than that of $M_{2} L$, suggesting that four $\alpha-D$-mannose groups from $M_{6} L_{5}$ interact independently with the mannose receptor. This seems to contrast with the finding that the affinity increases steadily rather than stepwise with increasing mannose valency. This apparent paradox may be explained from the negative cooperative binding of $M_{3} L_{2}-M_{6} L_{5}$ : binding of an additional $\alpha$-D-mannose to the receptor may attenuate the association of already bound mannose groups. Alternatively, the observed gain in binding energy with mannose valencies $\geq 2$ may arise from conformational effects. In that case, elongation of the cluster mannoside with a single mannose group may force adjacent mannose groups in a geometric configuration favourable for binding to the mannose receptor.

The complex nature of ligand binding by the mannose receptor was further illustrated by the Hill coefficients of the inhibition curves for cluster mannosides. The Hill coefficient of $\alpha$-D-mannose was significantly larger than 1. From the nonlinear regression analysis according to a two-site mixed stimulation/inhibition model, it can be concluded that the high Hill coefficient reflects a compromise between a stimulatory effect of $\alpha$-D-mannose at low concentrations $\left(\mathrm{SC}_{50}=250-400 \mu \mathrm{M}\right)$ and an inhibitory effect of $\alpha$-D-mannose at an $I_{50}$ of $10 \mathrm{mM}$. Binding of the first $\alpha$-D-mannose group to the high affinity site of the mannose receptor (possibly CRD4) may result in a 2-fold increased affinity of bio-t-PA or bio-Ribo B for the mannose receptor as was also reported by Oshimi et al. ${ }^{28}$ In agreement with Oshimi et al., ${ }^{28}$ this stimulatory effect is less pronounced for moderately potent ligands like $M_{2} L$ and absent for potent ligands like $M_{3} L_{2}$ to $M_{6} L_{5}$, as was reported in the same study. ${ }^{28}$ At higher concentrations, bound ligand is displaced from the mannose receptor by binding of $\alpha$-D-mannose to the low affinity site.

By contrast, $M_{3} L_{2}$ to $M_{6} L_{5}$ gave Hill coefficients of about 0.5 in both receptor sorbent assays and in the endothelial cell assay $\left(M_{6} L_{5}\right)$, while Hill coefficients of bio-Ribo $B$ or bio-t-PA indicated binding to a single site. Taking into account that the mannose receptor is a monomeric membrane-bound protein, this concurs with ligand binding to two (or more) separate but interacting sites within the mannose receptor. According to the binding model of Taylor and Drickamer et al., ${ }^{14}$ high affinity binding of proteins with high mannose-type glycosides like t-PA or ribonuclease B requires the cooperative action of CRD4 and CRD5. For optimal recognition of highly mannosylated polymers like mannan and invertase, the presence of five consecutive CRDs (CRD4-8) is imperative. Taken together it is tempting to identify CRD4 in concert with CRD5 as the first and CRD6-8 as the second binding unit. The first unit, embedding two carbohydrate recognition domains, is responsible for the binding of bio-Ribo B, bio-t-PA, $\alpha-D$-mannose and $M_{2} L$. For binding of polyvalent mannosides like $M_{3} L_{2}$ to $M_{6} L_{5}$, and mannan, both the first (CRD4-5) and the second unit (CRD6-8) participate in the binding process. Nonetheless, further study will be needed to conclusively unravel the intriguing process of ligand binding to the mannose receptor. 
In conclusion, we have devised and synthesized high affinity ligands for the mannose receptor, $M_{6} L_{5}$ being the most potent ligand yet synthesized. We anticipate that the nanomolar affinity of $M_{6} L_{5}$ is sufficiently high to allow application as a carrier device for cell-specific delivery of drugs/genes to macrophages and endothelial liver cells. Another relevant application which comes within reach involves antigen targeting to dendritic cells to stimulate major histocompatability complex-mediated antigen presentation by these cell type. Finally, $M_{6} L_{5}$ may also be a valuable therapeutic agent to prevent untimely clearance of the thrombolytic agent t-PA. In fact, preliminary studies in rats showed that administration of this mannoside resulted in a 2 -fold delayed clearance of t-PA. ${ }^{32}$

\section{ACKNOWLEDGEMENT}

This study was supported by grants from the Dutch Heart Foundation (grant no. M93.001 and 90.294)

\section{REFERENCES}

1. Maynard Y. and Baenziger J. U. (1981) J.Biol.Chem. 256: 8063-8068.

2. Lennartz M. R., Cole F. S., Shepherd V. L., Wileman T. E. and Stahl P. D. (1987) J.Biol.Chem. 262, 9942-9944.

3. Stahl P. D. (1990) Am.J.Respir.Cell.Mol.Biol. 2, 317-318.

4. Otter M., Kuiper J., van Berkel Th. J. C. and Rijken D. C. (1992) Ann.N.Y. Acad.Sci. 667, 431-442.

5. Ezekowitz R. A. B., Williams D. J., Koziel H., Armstrong M., Warner A., Richards F. F. and Rose R. M. (1991) Nature 351, 155-158.

6. Brunda M. J., Wiltrout R. H., Holden H. T. and Varesio L. (1983) Int.J.Cancer 31, 373-379.

7. Ezekowitz R. A. B., Sastry K., Bailly P. and Warner A. (1990) J.Exp.Med. 172, 1785-1794.

8. Smedsrød B., Melkko J., Ristelli L. and Ristelli J., (1991) Biochem.J. 271, 345-350.

9. Otter M., Barrett-Bergshoeff M. M., Rijken D. C. (1991) J.Biol.Chem. 266, 13931-13935.

10. Stahl, P. D. and Schlesinger P. H. (1980) Trends Biochem.Sci 5, 194-195.

11. Malhotra R., Wormald M. R., Rudd P. M., Fischer P. B., Dwek R. A. and Sijm R. B. (1995) Nature Medicine 1, 237 244.

12. Taylor M. E., Conary J. T., Lennartz M. R., Stahl P. D. and Drickamer K. (1990) J.Biol.Chem. 265, 12156-12162.

13. Taylor M. E. (1993) Biochem.Soc. Trans. 21, 468-473.

14. Taylor M. E. and Drickamer K. (1992) J.Biol.Chem. 268, 399-404.

15. Kéry V., Křepinský J. J. F., Warren C. D., Capek P., Stahl P. D. (1992) Arch.Biochem.Biophys. 298, 49-55.

16. Hoppe C. A., Lee Y. C. (1983) J.Biol.Chem. 258, 1419314199.

17. Jansen R. W., Molema G., Ching T. L., Oosting R., Harms G., Moolenaar F., Hardonck M. J., Meijer D. K. F. (1991) J.Biol.Chem. 266, 3343-3348.

18. Monsigny M., Kieda C., Roche A. (1983) Biol. Cell 47, 95-
110.

19. Kataoka M., Tavassoli M. (1984) J.Histochem.Cytochem. 32, 1091-1098.

20. Fraker P.J. and Speck J.C. Biochem.Biophys. Res.Commun., 80: 849-857.

21. De Rijke Y.B., Jurgens G., Hessels E.M.A.J., Hermann A., Van Berkel Th.J.C.. (1992) J.Lipid Res. 33: 1315-1325.

22. Otter M., Zockova P., Kuiper J., Van Berkel Th. J. C., Barrett-Bergshoeff M. M. and Rijken D. C. (1992) Hepatology 16, 54-59.

23. Biessen E.A.L., Bakkeren H.F., Beuting D.M., Kuiper J., and Van Berkel Th.J.C. (1994) Biochem.J., 299:291-296.

24. Biessen, E. A. L., Norder, J. A., Horn, A. S., and Robillard, G. T. (1988) Biochem. Pharmacol. 37, 3959-3966.

25. Otter, M., Kuiper J., Bos R., Rijken D.C., Van Berkel Th.J.C. (1992) Biochem.J., 284: 545-551.

26. Hoppe C. A. and Lee Y. C. (1984) Biochemistry. 23, 17231730.

27. Derrien D., Midoux P., Petit C., Negre E., Mayer R., Monsigny M. and Roche A. C. (1989) Glycoconjugate J. 6, 241-255.

28. Oshumi Y., Hoppe C. A., Ogawa T. and Lee Y. C. (1988) Arch. Biochem. Biophys. 260, 241-249.

29. Robbins J. C., Hanh Lam M., Tripp C. S., Bugianesi R. L., Ponpipom M. M., Shen T. Y. (1981) Proc.Natl.Acad.Sci.USA 78, 7294-7298.

30. Lee R.T., Ichikawa Y., Fay M., Drickamer K., Shao M.C. and Lee Y.C. (1991) J.Biol.Chem., 266: 4810-4815.

31. Biessen E. A. L., Beuting D. M., Roelen H. C. P. F., Van de Marel G. A., Van Boom J. H., and Van Berkel Th. J. C. (1995) J.Med. Chem. 38, 1538-1546.

32. Biessen E.A.L., Kuiper J., Van Teijlingen M.E., Vietsch H., Bijsterbosch M. K., Rijken D. C., and Th.J.C. Van Berkel (1996) Circulation 92: I-692.

33. Taylor M. E., Bezouška K., Drickamer K. (1992) J.Biol.Chem. 267, 1719-1726. 


\title{
CHAPTER 7
}

\section{Cluster mannosides can inhibit mannose receptor-mediated tissue-type plasminogen activator degradation by both rat and human cells.}

Femke Noorman', Marrie M. Barrett-Bergshoeff', Erik A.L Biessen ${ }^{2}$, Erika van de Bilt' ${ }^{2}$, Theo J.C van Berkel ${ }^{2}$, and Dingeman C. Rijken ${ }^{1}$

\author{
${ }^{1}$ Gaubius Laboratory, TNO Prevention and Health, \\ Leiden, The Netherlands \\ ${ }^{2}$ Division of Biopharmaceutics, Leiden/Amsterdam Center for Drug Research, \\ University of Leiden, The Netherlands
}

Reproduced from

Hepatology, 1997; in press 


\section{SUMMARY}

Recently we developed a series of cluster mannosides that were able to inhibit tissue-type plasminogen activator (t-PA) binding to the isolated mannose receptor. The mannoside with the highest affinity was able to inhibit t-PA clearance by the liver in the rat. To test whether these mannosides would also be efficient inhibitors in man, we studied the expression of the mannose receptor in the human liver and determined the efficacy of the mannosides to inhibit mannose receptor-mediated t-PA degradation by both rat and human cells.

Immunohistochemistry indicates that, like the rat, human liver endothelial cells and human Kupffer cells do express the mannose receptor. The mannosides do inhibit mannose receptor-mediated t-PA binding, association and degradation by isolated rat liver endothelial cells and t-PA association and degradation by cultured human macrophages at similar concentrations. The cluster mannoside with six mannose residues connected with a backbone of five lysine groups $\left(M_{6} L_{5}\right)$ was, like unlabeled t-PA, able to inhibit ${ }^{125} \mathrm{I}$-t-PA degradation in the $\mathrm{nM}$ range, while the mannoside $\mathrm{M}_{5} \mathrm{~L}_{4}$ inhibited ${ }^{125} \mathrm{I}$-t-PA degradation in the $\mu \mathrm{M}$ range. The concentrations of mannoside necessary to inhibit ${ }^{125} \mathrm{I}-\mathrm{t}-\mathrm{PA}$ degradation in vitro were comparable to the concentrations necessary to inhibit mannose receptor-mediated ${ }^{125}$-t-PA clearance in vivo.

We conclude that there is no species difference between rat and man with respect to the distribution of the mannose receptor in the liver and the affinity of the cluster mannosides, establishing the relevance of the inhibition of mannose receptor-mediated t-PA clearance by $M_{6} L_{5}$ as observed in the rat, for the human situation.

\section{INTRODUCTION}

Tissue-type plasminogen activator (t-PA) is a serine protease that activates fibrinolysis by converting plasminogen into plasmin, which cleaves fibrin into soluble degradation products. ${ }^{1,2}$ Because of its fibrin-selective action, t-PA is successfully used for thrombolytic therapy, e.g., after myocardial infarction. ${ }^{3}$ Recombinant t-PA $(70 \mathrm{kD})$ contains a single high mannose-type oligosaccharide and one or two complex-type oligosaccharides. ${ }^{4}$ In both rat and humans, t-PA is rapidly cleared mainly by the liver. ${ }^{5,6}$ It has been shown that, in the rat, t-PA is cleared from plasma through both the mannose receptor and the $\alpha_{2}$-macroglobulin receptor/ low density lipoprotein receptor-related protein (LRP). ${ }^{5,7-10}$

Because of its rapid clearance in man, large doses of t-PA must be administered to achieve efficient thrombolysis. Coadministration of inhibitors of t-PA clearance with t-PA would reduce the therapeutic dose of t-PA required for efficient thrombolysis. Furthermore myocardial infarction patients can have a large variability of liver blood flow. ${ }^{11}$ The liver blood flow strongly influences the t-PA clearance. Reduced liver blood flow causes a decreased plasma clearance and increased plasma levels of endogenous or infused t-PA in humans. ${ }^{12,13}$ Thus, reduced liver blood flow may lead to t-PA overdosing and an increased bleeding risk in patients. Coadministration of inhibitors of t-PA clearance would also reduce the influence of liver blood flow on the t-PA concentration, and thereby reduce the risk of t-PA overdosing. The inhibitors may in addition be used to inhibit the clearance of endogenous t-PA in order to enhance the fibrinolytic activity in blood and to prevent thrombosis. 
We have shown that the uptake and degradation of t-PA by cultured human macrophages are mediated by both the mannose receptor and LRP, thus these cells are a good in vitro model for the plasma clearance of t-PA by the liver. ${ }^{14}$ In the human liver the LRP is present on hepatocytes and Kupffer cells. ${ }^{15}$ The mannose receptor has been shown to be present in rat ${ }^{7,16}$ and bovine ${ }^{17}$ liver on liver endothelial cells and Kupffer cells. The $175 \mathrm{kD}$ mannose receptor can be isolated from human liver, ${ }^{18}$ but its cellular localization in human liver has not yet been demonstrated.

Recently, we synthesized cluster mannosides with two to six terminal mannose residues connected to an (oligo)lysine backbone by flexible elongated spacers $\left(M_{2} L_{1}\right.$ to $\left.M_{6} L_{5}\right)$. These mannosides can inhibit tPA binding to the isolated immobilised mannose receptor. The affinity of the mannosides increased approximately 10 times from the $\mu \mathrm{M}$ to the (sub) $\mathrm{nM}$ range with each increment of a mannose residue attached to the backbone. ${ }^{19}$ We showed that the most potent mannoside from this study $\left(M_{6} L_{5}\right)$, in combination with an inhibitor of LRP, effectively inhibited t-PA plasma clearance in rats. ${ }^{10}$ This indicated that the aforementioned strategy to delay t-PA clearance using mannose receptor inhibitors is feasible in the rat. No information is available about the effect of these mannosides on mannose receptor mediated t-PA degradation by human cells.

To explore the potentials of the cluster mannosides as mannose receptor antagonists or ligands in humans, we tested the mannosides in both rat and human models. We provided the first evidence for the presence of the mannose receptor on human liver endothelial cells and Kupffer cells by immunohistochemistry. Isolated rat liver endothelial cells and cultured human macrophages were used to test the efficacy of the cluster mannosides $M_{5} L_{4}$ and $M_{6} L_{5}$ to inhibit mannose receptor-mediated t-PA binding and/or degradation. The in vitro inhibitory effect of the mannosides was compared to the inhibitory effect of the mannosides on t-PA clearance in vivo in the rat.

\section{MATERIALS AND METHODS}

\section{Materials}

The synthesis and structure of the cluster mannosides $\quad M_{6} L_{5}, \quad M_{5} L_{4}, \quad M_{4} L_{3}, \quad M_{3} L_{2}$ and $\quad M_{2} L_{1}$ was as described elsewhere. ${ }^{19}$ Bovine serum albumin (BSA) fraction $V$ and collagenase (type I and IV) were obtained from Sigma Chemical Co. (St.Louis MO, USA). Nycodenz was from Nycomed Pharma AS (Oslo, Norway) and 2-[4-(2-hydroxyethyl)-1-piperazinyl]-ethanesulfonic acid (HEPES) was from Merck (Darmstadt, FRG). Wistar rats were from the Sylvius Laboratories, (University of Leiden, The Netherlands). Human $\mathrm{AB}^{+}$serum, and thrombocyte-poor pooled buffy coats from healthy donor blood (pooled from 5 donors with the same blood type combined, and serum added to preserve the cells), were obtained from the Red Cross Blood Bank (The Hague and Leiden, The Netherlands). Lymphoprep ${ }^{T M}$ (Nycomed Pharma AS, Oslo, Norway) with a density of $1.077 \mathrm{~g} / \mathrm{ml}$ was used for density gradient centrifugation. Heparin (Leo Pharmaceutical Products, Ballerup, Denmark), cell culture medium M199 (Flow Laboratories, Irvine, UK), Penicillin/Streptomycin (Pen/strep, Boehringer Mannheim, Mannheim, Germany), and sterile buffers were used to isolate and culture the monocytes. Dexamethasone was purchased from Sigma Chemical Co. (St.Louis, MO, USA). Recombinant t-PA (Actilyse) was obtained from Boehringer Ingelheim (Ingelheim, Germany). Mannan extracted from Saccharomyces cerevisiae, prepared by the cetavlon method was obtained from Sigma Chemical Co. (St.Louis MO, USA). The fusion protein of glutathione-Stransferase and $\alpha_{2}$-macroglobulin receptor-associated protein (GST-RAP) was a generous gift from Dr J. Kuiper who used the Salmonella japonicum glutathione-S-transferase (GST)-RAP expression plasmid. ${ }^{20}$ (provided by Dr. J.Herz, University of Texas,

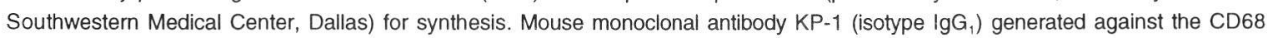
antigen was obtained from Dako A/S (Glostrup, Denmark). Mouse monoclonal antibody 15-2 (isotype IgG $\mathrm{G}_{1}$ ) generated against the isolated human mannose receptor was prepared as described previously. ${ }^{21}$ Human liver cryostat sections were obtained from biopsy samples and snap-frozen in liquid nitrogen (Department of Pathology, Slotervaart Hospital, Amsterdam, The Netherlands).

\section{Immunohistochemistry of the mannose receptor}

Tissue sections of $8 \mu \mathrm{m}$ thickness were cut on a Reichert-Jung 2800 frigocut cryostat, transferred to poly-L-lysine-coated microscope slides, air dried for $30 \mathrm{~min}$ at room temperature and fixed in acetone/chloroform 1:1 (10 min at $\left.4^{\circ} \mathrm{C}\right)$. After washing with phosphate buffered saline (PBS) the tissue sections were pre-incubated with normal rabbit serum for 5 minutes. Excess serum was 
discarded and the sections were incubated with primary antibody (mAb 15-2 or KP-1) for 30 min at room temperature. After rinsing in PBS, the sections were incubated with secondary antibody (rabbit anti-mouse, Dako AV, Glostrup, Denmark) for 15 min at room temperature. After rinsing with PBS the sections were incubated for $30 \mathrm{~min}$ with an alkaline-phosphatase-conjugated mouse monoclonal antibody directed against alkaline phosphatase (Dako A/S, Glostrup, Denmark). The alkaline phosphatase was visualized in red by incubating the section for $30 \mathrm{~min}$ in the dark with naphtol-AS-MX-phosphate (Sigma Chemical Co., St.Louis, MO) and New Fuchsine (Chroma Gezellschaft, Köngen, BRD) as a coupling salt. ${ }^{21,22}$ The alkaline phosphatase was visualized in blue by incubating the section for $30 \mathrm{~min}$ at room temperature in the dark with a modified substrate solution described by Cordell et al.. ${ }^{23}$ The solution was prepared by dissolving naphtol-AS-MX-phosphate in dimethylformamide and $0.2 \mathrm{M} \mathrm{Tris-HCl} \mathrm{pH} \mathrm{8.0.} \mathrm{Directly} \mathrm{before} \mathrm{use}$ $0.5 \mathrm{mg} / \mathrm{ml}$ Fast Blue BB and $0.05 \mathrm{mg} / \mathrm{ml}$ levamisole (Sigma Chemical Co. St.Louis, MO) were added, and the solution was filtered.

To obtain a double staining for both the mannose receptor and $\mathrm{CD} 68$, the above-mentioned procedure was performed with KP-1 as the first primary antibody and the alkaline phosphatase was stained red for $30 \mathrm{~min}$. The stained sections were extensively washed with PBS and incubated for $5 \mathrm{~min}$ with normal rabbit serum, and the above-mentioned procedure was repeated now with mAb 15-2 as the primary antibody, and the alkaline phosphatase was stained blue for $15 \mathrm{~min}$.

Finally the sections were rinsed with aqua dest, counterstained with either Mayers haematoxylin (blue) or Fast nuclear red (red), air dried, and mounted in DePeX mounting medium (BDH, Poole, UK). In control sections no primary antibody was used. The identity of the cells was judged on the basis of their morphology and location in the tissue.

\section{Rat liver endothelial cell isolation}

In this study male Whistar rats were used which had free access to standard chow diet (Hope farms, Woerden, The Netherlands) and tap water; they were kept on a $12 \mathrm{hr}$ day/night cycle and received humane care. Rats ( 12-weeks old males) were anaesthesized by intraperitoneal injection with $20 \mathrm{mg}$ of pentobarbital. The vena porta was cannulated and the liver was perfused with Hank's buffer supplemented with Hepes and collagenase for 20 minutes at $37^{\circ} \mathrm{C}$. The liver endothelial cells were isolated by use of density gradient centrifugation (Nycodenz) and centrifugal elutriation. ${ }^{24}$ Purity $(>99 \%)$ and viability $(>90 \%)$ were judged by respectively peroxidase staining (Kupffer cell staining) and trypan blue exclusion.

\section{Monocyte isolation and cultivation}

Monocytes were isolated from pooled human buffy coats as described earlier. ${ }^{14}$ Buffy coat $(100 \mathrm{ml})$ was diluted with $180 \mathrm{ml}$ phosphate buffered saline (PBS, $2.7 \mathrm{mM} \mathrm{KCl}, 137 \mathrm{mM} \mathrm{NaCl}, 8.1 \mathrm{mM} \mathrm{Na}_{2} \mathrm{HPO}_{4}, 1.46 \mathrm{mM} \mathrm{KH}_{2} \mathrm{PO}_{4}, \mathrm{pH} 7.4$ ) containing 10 units/ml heparin. Using density gradient centrifugation with Lymphoprep, routinely 5 to $10 \times 10^{8}$ cells were obtained. These cells were resuspended in culture medium (M199 containing $10 \mathrm{mg} / \mathrm{ml}$ glutamine, $50 \mathrm{U} / \mathrm{ml}$ penicillin, $50 \mu \mathrm{g} / \mathrm{ml}$ streptomycin) and $5 \times 10^{6}$ cells $/ \mathrm{ml}$ were seeded in 24-well culture plates. After one hour, the nonadherent cells were removed with medium, and cells were cultured in culture medium containing $0.1 \mu \mathrm{g} / \mathrm{ml}$ dexamethasone and $10 \%(\mathrm{v} / \mathrm{N})$ human $\mathrm{AB}^{+}$serum. After 2 days the monocytes were differentiated to macrophages and used for degradation studies.

\section{Labeling of t-PA}

Recombinant t-PA was labeled with ${ }^{125} \mathrm{I}$ using the iodogen method. ${ }^{14}$ Polyethylene vessels of $1.5 \mathrm{ml}$ were coated with $10 \mu \mathrm{\mu g}$ iodogen. $50 \mu \mathrm{g} \mathrm{t}-\mathrm{PA}$ in $0.2 \mathrm{M}$ arginine $\mathrm{pH} 8$, was incubated with $0.5 \mathrm{mCi} \mathrm{Na}{ }^{125}$ for $10 \mathrm{~min}$ at room temperature in the vessel. The mixture was transferred to another vessel containing an equal volume of $4 \mathrm{mg} / \mathrm{ml} \mathrm{KI}$ to avoid non-specific binding of ${ }^{125}$ to $\mathrm{t}-\mathrm{PA}$. Labeled t-PA was separated from free ${ }^{125}$ I using a $10 \mathrm{ml}$ Sephadex G25 Coarse column (eluent $50 \mathrm{mM} \mathrm{Tris-HCl}, 1 \mathrm{M} \mathrm{NaCl}, 0.01 \%(\mathrm{v} / \mathrm{v})$ Tween 80,1 $\mathrm{mg} / \mathrm{ml} \mathrm{BSA}, \mathrm{pH}$ 8). Labeling resulted in approximately $600 \mathrm{cpm} / \mathrm{fmol}$, with $80 \%$ recovery of t-PA activity.

\section{Binding, association and degradation of ${ }^{125}$ I-t-PA by rat liver endothelial cells}

As described previously, ${ }^{7}$ freshly isolated rat liver endothelial cells were incubated with $1 \mathrm{nM}{ }^{125}$-t-PA in HAM's F10 buffer supplemented with $25 \mathrm{mM}$ Hepes, $20 \mathrm{mg} / \mathrm{ml} \mathrm{BSA}$, and $0.01 \%(\mathrm{v} / \mathrm{v})$ Tween $80, \mathrm{pH} 7.4$ at $4^{\circ} \mathrm{C}$ (binding $2 \mathrm{hr}$ ) or $37^{\circ} \mathrm{C}$ (association 15 $\mathrm{min}$ and degradation $1 \mathrm{hr}$ ) under constant rotation. After incubation the cells were washed twice with cold $50 \mathrm{mM} \mathrm{Tris-HCL}, 0.15 \mathrm{M}$ $\mathrm{NaCl}, 2.5 \mathrm{mM} \mathrm{CaCl}, 2 \mathrm{mg} / \mathrm{ml} \mathrm{BSA}, 0.01 \%$ Tween $80, \mathrm{pH} 7.4$, and once with this buffer without BSA. The cells were resuspended in water and radioactivity was measured. Degradation products in the medium were measured after precipitation with $10 \%(\mathrm{~W} / \mathrm{V}$ ) trichloroacetic acid (TCA) and subsequent extraction of the supernatant with chloroform (see below). Binding, association and degradation were measured and corrected for protein, as measured according to the Lowry method. Specific binding, association or degradation were defined as the residual binding, association and degradation after subtraction of radioactivity determined in the presence of $1 \mathrm{mg} / \mathrm{ml}$ mannan or $100 \mathrm{mM}$ mannose. Under the current conditions the non-specific binding was $14.3 \pm 6.4 \%$, the non-specific association was $3.7 \pm 3.8 \%$ and the non-specific degradation was $8.3 \pm 5.2 \%$ of control).

\section{Association and degradation of ${ }^{125}$ l-t-PA by human macrophages}

As described previously. ${ }^{14}$ the macrophages were washed (3x with PBS containing $0.9 \mathrm{mM} \mathrm{CaCl}_{2}, 0.5 \mathrm{mM} \mathrm{MgCl}, 10 \mathrm{mg} / \mathrm{ml} \mathrm{BSA}$, 
$\mathrm{pH} 7.4,4^{\circ} \mathrm{C}$ ), and incubated with 1 to $17 \mathrm{nM}^{125} \mathrm{l}$-t-PA and $100 \mathrm{nM}$ GST-RAP (for association experiments 20 mM 6-aminohexanoic acid was also added), with or without mannosides in $300 \mu \mathrm{l} \mathrm{M199,} 10 \mathrm{mg} / \mathrm{ml} \mathrm{BSA}, 0.01 \%(\mathrm{v} / \mathrm{V})$ Tween 80 , at $37^{\circ} \mathrm{C}$ in $5 \% \mathrm{CO}_{2} / 95 \%$ air. After incubation, cell media were collected and the cells were washed four times with PBS, pH 7.4 containing $20 \mathrm{mM} 6$ aminohexanoic acid and $0.1 \%$ BSA and lysed with $500 \mu \mathrm{l} 1 \%$ Triton $X-100$ for 15 minutes at room temperature. The lysates were collected and another $500 \mu \mathrm{l} 1 \%$ Triton X-100 was added to the wells, collected and added to the above-mentioned lysate. Radioactivity of the lysates was determined. Specific association was defined as the residual binding after subtraction of radioactivity determined in the presence of $1 \mathrm{mg} / \mathrm{ml}$ mannan. Under the current conditions the non-specific association was $19.8 \pm 8.6 \%$ of control. TCA was added to the cell media (final conc. $10 \% \mathrm{w} / \mathrm{v}$ ). Non-degraded ${ }^{125} \mathrm{I}-\mathrm{t}$-PA was precipitated by centrifugation (10 min $15000 \mathrm{~g}$ ). To eliminate the possibility that the cells might deiodinate rather than degrade ${ }^{125} \mathrm{I}-t-P A$, free ${ }^{125}$ l was extracted. To $500 \mu$ TCA soluble supernatant obtained, $5 \mu \mathrm{l} 400 \mathrm{mg} / \mathrm{ml} \mathrm{KI}$ and $25 \mu \mathrm{H}_{2} \mathrm{O}_{2} 30 \%(\mathrm{v} / \mathrm{v}$ ) were added. After 5 minutes the free iodine was extracted with $800 \mu \mathrm{l}$ chloroform. The radioactivity of the remaining ${ }^{125} \mathrm{I}$-tyrosine (and possibly ${ }^{125} \mathrm{I}$-peptides) in the upper layer (5 min $15000 \mathrm{~g}$ ) representing degraded ${ }^{125}$ |-t-PA was determined. Degradation was corrected for radioactivity determined in wells incubated without cells. Specific degradation was defined as the residual degradation after subtraction of radioactivity determined in the presence of $1 \mathrm{mg} / \mathrm{ml}$ mannan. Under the current conditions the non-specific degradation was $6.0 \pm 4.8 \%$ of control.

\section{Analysis of inhibition curves}

From the inhibition data of the binding, association or degradation of non-saturating concentrations of ${ }^{125}$-t-PA by unlabeled t-PA or other compounds, specific ${ }^{125} \mathrm{l}-\mathrm{t}-\mathrm{PA}$ binding, association and degradation were calculated and expressed as a percentage of control. To calculate the binding parameters of the inhibitors (log half maximal inhibitory concentration $\left(\log I \mathrm{C}_{50}\right.$ ), and Hill-slopes) the resulting inhibition curves were fitted as a sigmoid curve using nonlinear regression analysis with the computer program GraphPAD (ISI Software, Philadelphia, PA, USA). "Goodness of fit" was assessed by evaluating the actual distance of the measurements from the fitted line (no weighing).

\section{Plasma clearance of therapeutic doses of $t-P A$ in the rat}

Twelve-week-old male Wistar rats $(225-275 \mathrm{~g})$ were anesthetized by intraperitoneal injection with $20 \mathrm{mg}$ of pentobarbital. The abdomen was opened. Inhibitor in $250 \mu$ PBS was injected into the vena cava one minute before $600 \mu \mathrm{g} / \mathrm{kg}$ radiolabeled t-PA in 500 $\mu \mathrm{l}$ PBS was injected. At 1, 2, 5, 10, 20, and $30 \mathrm{~min}$ blood samples $(0.3 \mathrm{ml})$ were taken with heparinized syringes from the vena cava. Concentration of t-PA in plasma was calculated as the percentage of the injected dose, and clearance was expressed as the area under the curve (AUC) from 0 to 30 minutes.

\section{RESULTS}

Recently we developed a mouse monoclonal antibody (mAb 15-2) against the human mannose receptor. By the use of $m A b 15-2$, we can specifically detect mannose receptor-expressing human macrophages in flow cytometry and in cryostat sections of human tissue. ${ }^{22}$ mAb KP-1 detects the CD68 antigen expressed by myeloid cells. ${ }^{25}$ It has the same isotype as mAb 15-2, and thus also served as a negative control. We compared the staining patterns of these two $\mathrm{mAb}$ in single and double staining of cryostat sections of human liver. As shown in Fig 1 (see appendix, page 148,149) the CD68 antigen was only present on Kupffer cells whereas the mannose receptor was present on both human liver endothelial cells and Kupffer cells. No staining was observed in controls.

To evaluate the affinity of the cluster mannosides for the mannose receptor as expressed on cells, we tested their ability to inhibit t-PA binding to rat liver endothelial cells at $4^{\circ} \mathrm{C}$ (Fig 2). Previously, we have shown that $M_{6} L_{5}$ inhibited t-PA binding to rat liver endothelial cells in the $n M$ range. Here we show that $M_{5} L_{4}$ inhibited t-PA binding in the $\mu M$ range. The mannosides $M_{4} L_{3}, \quad M_{3} L_{2}, M_{2} L_{1}$ all inhibited t-PA binding like $M_{5} L_{4}$ in the $\mu M$ range $\left(I C_{50} 4-7 \mu M\right.$ ), while mannose inhibited t-PA binding in the $m M$ range $\left(I C_{50} 3 \mathrm{mM}\right.$ ) (not shown). At $37^{\circ} \mathrm{C}$, t-PA bound to the mannose receptor is internalized, the ligand is released in the endosomes and the mannose receptor is recycled to the membrane. After a lag phase of 10 to 15 minutes degradation products of t-PA appear in the medium. ${ }^{7.14}$ We evaluated the $M_{6} L_{5}$ and $\mathrm{M}_{5} \mathrm{~L}_{4}$ inhibition of t-PA binding and internalization (association) for $15 \mathrm{~min}$ at $37^{\circ} \mathrm{C}$ by rat liver endo-thelial cells (Fig 3). The association was inhibited at similar mannoside concentrations as the binding at $4^{\circ} \mathrm{C}$. We therefore conclude that the temperature did not influence the efficacy of the inhibitors. 


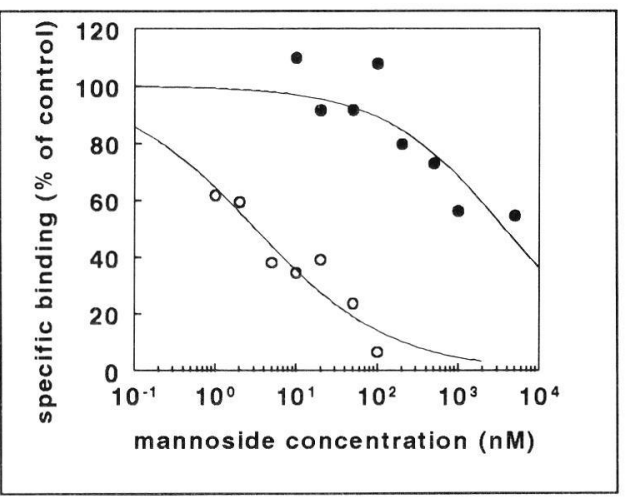

Fig $2 M_{6} L_{5}$ and $M_{5} L_{4}$ inhibition of ${ }^{125} \mathrm{I}$-t-PA binding to isolated rat liver endothelial cells at $4^{\circ} \mathrm{C}$.

Rat liver endothelial cells were incubated with ${ }^{125} \mathrm{I}-\mathrm{t}-\mathrm{PA}$ and different concentrations of inhibitor for 2 hours at $4{ }^{\circ} \mathrm{C}$. The cells were washed, and bound radioactivity was determined. Data were corrected for non-mannose receptor specific binding and expressed as a percentage of control. $M_{6} L_{5}(O)$, $\mathrm{n}=2, \mathrm{M}_{5} \mathrm{~L}_{4}(\bullet), \mathrm{n}=2$.

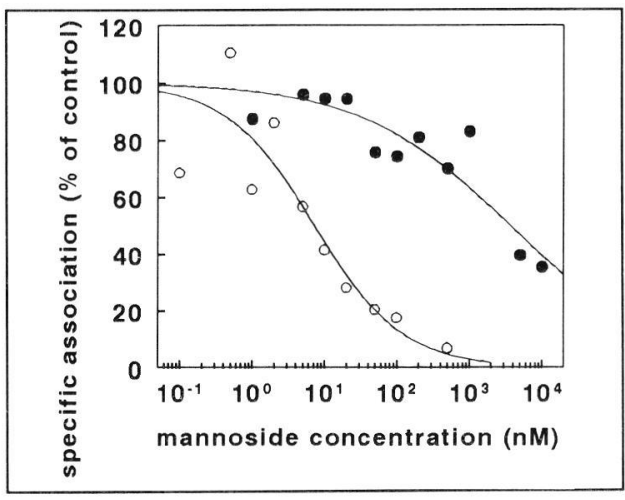

Fig $3 M_{6} L_{5}$ and $M_{5} L_{4}$ inhibition of ${ }^{125}$ I-t-PA association to isolated liver endothelial cells at $37^{\circ} \mathrm{C}$.

Rat liver endothelial cells were incubated with ${ }^{125} \mathrm{I}-\mathrm{t}-\mathrm{PA}$ and different concentrations of inhibitor for 15 minutes at $37^{\circ} \mathrm{C}$. The cells were washed and bound radioactivity was determined. Data were corrected for non-mannose receptor specific association and expressed as a percentage of control. $M_{6} L_{5}(O) n=1, M_{5} L_{4}(\bullet), n=2$.

To study the effect of the mannosides on human cells we cultured isolated human monocytes that differentiated to macrophages. As human macrophages express both the mannose receptor and LRP they are a suitable in vitro model to study t-PA clearance. ${ }^{14}$ To enhance the ratio of mannose receptor mediated t-PA degradation we up-regulated mannose receptor expression using dexamethasone. ${ }^{14} \mathrm{At}$ $4{ }^{\circ} \mathrm{C}$, only a small amount of t-PA binds to the macrophages. Of this binding, approximately $50 \%$ is inhibited by the lysine analog 6 -aminohexanoic acid (that does not affect t-PA degradation ${ }^{14}$ ), whereas only $10 \%$ of the binding is inhibited by mannan and $10 \%$ by GST-RAP. Thus the macrophages were not suitable for studying mannose receptor-mediated binding of t-PA at $4{ }^{\circ} \mathrm{C}$. Like the mannose receptor on rat liver endothelial cells the mannose receptor on macrophages is recycled at $37^{\circ} \mathrm{C}$, and $\mathrm{t}-\mathrm{PA}$ mannose receptor-mediated association was studied for 1 hour in human macrophages in the presence of GST-RAP and 6-aminohexanoic acid. As shown in Fig 4, $M_{6} L_{5}$ and $M_{5} L_{4}$ inhibited mannose receptormediated t-PA association by human macrophages in the $\mathrm{nM}$ range and the $\mu \mathrm{M}$ range, respectively.

To study the mannose receptor-mediated t-PA degradation, LRP-mediated t-PA degradation was inhibited using GST-RAP. ${ }^{14}$ Under these conditions t-PA degradation is inhibited by $1000 \mathrm{nM}$ unlabeled $\mathrm{t}$-PA for $95 \%$ (Fig 5) and by $1 \mathrm{mg} / \mathrm{ml}$ mannan for $94 \%$ (not shown). As shown in Fig 6 the degradation of t-PA was inhibited by $M_{6} L_{5}$ with a similar affinity as unlabeled t-PA in both the presence and the absence of GST-RAP. Because the inhibition in the absence and presence of GST-RAP was similar, we may conclude that LRP-mediated t-PA degradation was not affected by $M_{6} L_{5}$. Furthermore the compound did not appear to be toxic to the human macrophages, because no cell death was observed and the inhibitory activity of $5 \mu \mathrm{M} \mathrm{M}_{6} \mathrm{~L}_{5}$ was maintained at a constant level $(81.3 \pm 5.2 \%$ ) for at least 6 hours (Fig 7). 

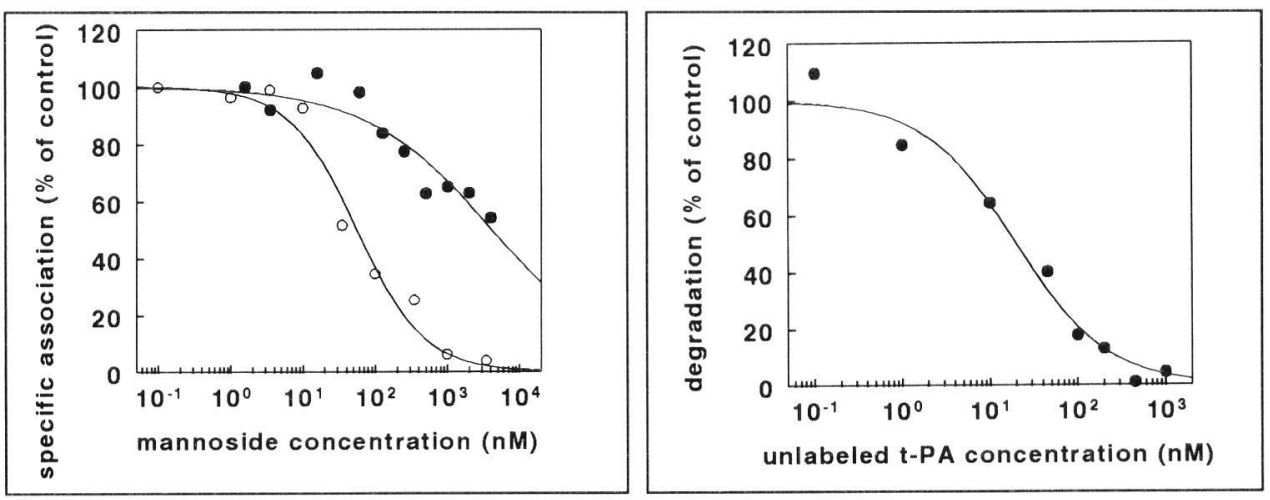

Fig $4 M_{6} L_{5}$ and $M_{5} L_{4}$ inhibition of ${ }^{125}$ I-t-PA association to Fig 5 t-PA inhibition of ${ }^{125}$ I-t-PA degradation by cultured cultured human macrophages at $37^{\circ} \mathrm{C}$. human macrophages in the presence of GST-RAP.

Human macrophages were incubated with ${ }^{125}$-t- $-\mathrm{PA}$ in the Human macrophages were incubated with ${ }^{125}$ /-t-PA in the presence of $100 \mathrm{nM}$ GST-RAP, $20 \mathrm{mM} \mathrm{6-amino-hexanoic} \mathrm{acid} \mathrm{presence} \mathrm{of} 100 \mathrm{nM}$ GST-RAP and different concentrations of and different concentrations of mannosides. The cells were unlabeled t-PA for 1 hour at $37{ }^{\circ} \mathrm{C}$. Medium was sampled and incubated for 1 hour at $37^{\circ} \mathrm{C}$. Cells were washed and lysed, and degradation of ${ }^{125}$-t-PA was determined. Data were expressed as ${ }^{125}$ I-t-PA association was determined. Data were corrected for a percentage of control.

non-mannose receptor specific association and expressed as a percentage of control. $M_{6} L_{5}(O), n=2, M_{5} L_{4}(\bullet), n=2$.
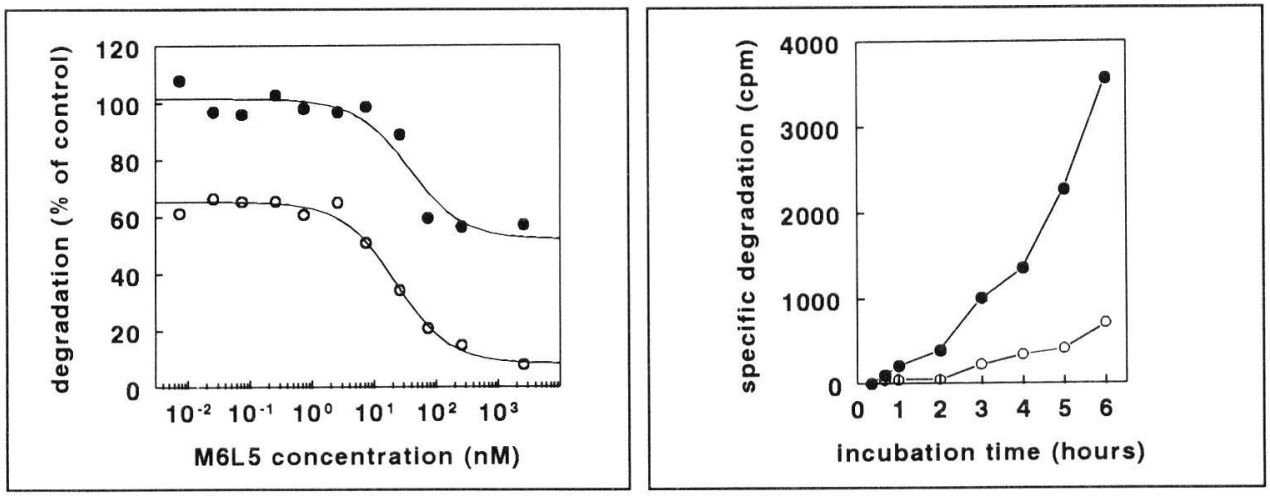

Fig $6 M_{6} L_{5}$ inhibition of ${ }^{125}$ l-t-PA degradation by human Fig $7 M_{6} L_{5}$ inhibition of ${ }^{125}$ I-t-PA degradation by human macrophages in the presence or absence of GST-RAP. macrophages at various times of incubation.

Human macrophages were incubated with ${ }^{125} \mathrm{I}$-t-PA and different Human macrophages were incubated with ${ }^{125} \mathrm{I}-\mathrm{t}-\mathrm{PA}$ and $100 \mathrm{nM}$ ccncentrations of inhibitor for 1 hour at $37{ }^{\circ} \mathrm{C}$. Medium was GST-RAP with or without $5 \mu \mathrm{M} \mathrm{M}_{6} \mathrm{~L}_{5}$ for various periods in sampled and the degradation product of ${ }^{125}$-t-PA was separate wells. From each well, medium was sampled, and the determined. Data were expressed as a percentage of control. degradation of t-PA was determined. Data were corrected for Inhibition in the presence of $100 \mathrm{nM}$ GST-RAP (O), $\mathrm{n}=2$, non-mannose receptor specific degradation and expressed as the inhibition in the absence of GST-RAP $(\bullet), n=2$. specific degradation $\mathrm{cpm}$ present in the sample. Control degradation ( ), n=2), degradation in the presence of $5 \mu M_{6} \mathrm{M}_{5}$ (O), $n=2$. 
Subsequently, the mannoside inhibition of mannose receptor-mediated t-PA degradation was determined in both human macrophages and rat liver endothelial cells over an incubation period of 1 hour at $37^{\circ} \mathrm{C}$ (Fig 8). The mannose receptor-mediated t-PA degradation by both cell types was inhibited at similar concentrations of $\mathrm{M}_{6} \mathrm{~L}_{5}\left(\mathrm{IC}_{50} 30-50 \mathrm{nM}\right)$ and $\mathrm{M}_{5} \mathrm{~L}_{4}\left(\mathrm{IC}_{50}\right.$ 3-16 $\left.\mu \mathrm{M}\right)$. We conclude that there is no species difference between rat and man with respect to the affinities of $M_{6} L_{5}$ and $M_{5} L_{4}$ toward the mannose receptor.

\section{Fig 8}

$M_{6} L_{5}$ and $M_{5} L_{4}$ inhibition of ${ }^{125}$ I-t-PA degradation by isolated rat liver endothelial cells and cultured human macrophages.

Human macrophages were incubated with ${ }^{125} \mathrm{I}$-t-PA and $100 \mathrm{nM}$ GST-RAP, while rat liver endothelial cells were incubated with ${ }^{125}$ /-t-PA. Both cell-types were coincubated with different concentrations of inhibitor for 1 hour at $37^{\circ} \mathrm{C}$. Medium was sampled, and the degradation of ${ }^{125}$-t-PA was determined. Data were corrected for nonmannose receptor specific degradation and expressed as a percentage of control. Inhibition curves obtained with rat liver endothelial cells are represented by a dotted line, those obtained with human macrophages by a solid line. $M_{6} L_{5}$ and rat cells $(O) n=2$, $M_{6} L_{5}$ and human cells (- $n=6$,

$M_{5} L_{4}$ and rat cells $(\square), n=2$,

$M_{5} L_{4}$ and human cells (E), $n=6$.

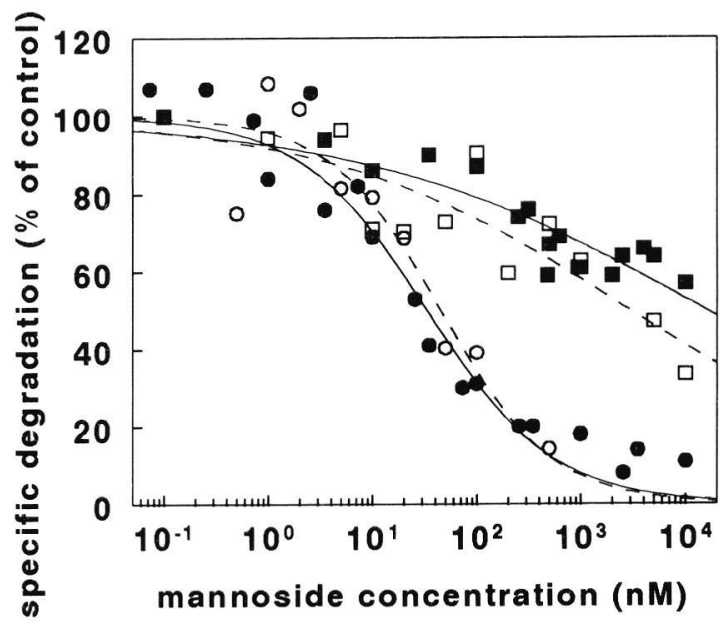

To evaluate the predictive value of the in vitro assays for in vivo inhibition of mannose receptormediated t-PA clearance, we tested the ability of cluster mannoside $M_{5} L_{4}$ to inhibit t-PA clearance at 0.3 $\mathrm{mg} / \mathrm{rat}$ and compared these results to the recently described effect of two different doses of $\mathrm{M}_{6} \mathrm{~L}_{5} .{ }^{10}$ As shown in Table 1, $\mathrm{M}_{5} \mathrm{~L}_{4}$ inhibited t-PA clearance for only $38.9 \%$ at a dose of $0.3 \mathrm{mg}$, which is significantly lower than the $58.7 \%$ inhibition achieved with the same dose of $\mathrm{M}_{6} \mathrm{~L}_{5}$. Even a ten times lower dose of $M_{6} L_{5}(0.03 \mathrm{mg})$ gave a stronger inhibition of t-PA clearance $(47.6 \%)$ than $M_{5} L_{4}$. Comparison of the potency of the mannosides to inhibit t-PA degradation in vitro with ine inhibition of t-PA clearance in vivo (see discussion) suggests that it is possible to extrapolate the effects observed on t-PA degradation by isolated cells (rat and human) to the effects observed on t-PA clearance in the rat.

\section{DISCUSSION}

In both rat and man the main clearance organ of t-PA is the liver. ${ }^{5,6}$ Recently we developed a monoclonal antibody (mAb 15-2) that specifically recognizes the $175 \mathrm{kD}$ human mannose receptor and not other mannose binding proteins or mannose receptor-related proteins ${ }^{21,22}$ By the use of mAb 15-2 we show for the first time that there is no species difference concerning the distribution of the mannose receptor in the liver because it is present on human liver endothelial and Kupffer cells similar to the bovine liver and rat liver. ${ }^{7,16,17}$ 
TABLE 1 Inhibition of t-PA clearance in the rat by intravenous administration of the cluster mannosides.

\begin{tabular}{|cccc|}
\hline inhibitor & inhibitor concentration $(\mu \mathrm{M})$ & $\begin{array}{c}\text { AUC of t-PA } \\
\text { (\%dose.min) }\end{array}$ & $\begin{array}{c}\text { inhibition of } \\
\text { t-PA clearance (\%) }\end{array}$ \\
\hline control & 0 & $231 \pm 45$ & 0 \\
$\mathrm{M}_{5} \mathrm{~L}_{4}(0.3 \mathrm{mg})$ & $2.8-17$ & $379 \pm 20$ & 38.9 \\
$\mathrm{M}_{6} \mathrm{~L}_{5}(0.03 \mathrm{mg})$ & $0.24-1.5$ & $442 \pm 59$ & 47.6 \\
$\mathrm{M}_{6} \mathrm{~L}_{5}(0.3 \mathrm{mg})$ & $2.4-15$ & $560 \pm 47$ & 58.7 \\
\hline
\end{tabular}

"Calculated range of the plasma concentration of the inhibitor after injection when the inhibitor is distributed over total body fluid (approximately $50 \mathrm{ml}$ ) or only the plasma volume (approximately $8 \mathrm{ml}$ )

Recently we developed cluster mannosides which were able to inhibit binding of t-PA to the isolated mannose receptor ${ }^{19}$ and t-PA clearance in the rat. ${ }^{10}$ To explore possible applications of the cluster mannosides as mannose receptor antagonists or ligands in man, for example to improve the pharmacokinetic properties of t-PA, we compared their effect on t-PA degradation by mannose receptor expressing rat cells with their effect on human cells in vitro.

The mannosides $M_{6} L_{5}$ and $M_{5} L_{4}$ inhibited mannose receptor-mediated t-PA binding and association by rat liver endothelial cells. $M_{6} L_{5}$ did not affect LRP-mediated t-PA degradation by human macrophages, nor did it show toxicity towards these cells. This is in agreement with previous findings showing that no toxicity of $0.3 \mathrm{mg} \mathrm{M}_{6} \mathrm{~L}_{5}$ could be detected in vivo in the rat. ${ }^{10}$ Furthermore we showed that the mannose receptor-mediated t-PA association and degradation by rat liver endothelial cells and human macrophages was similarly inhibited by the mannosides. On both celltypes, $M_{6} L_{5}$ inhibited $t-P A$ degradation in the $\mathrm{nM}$ range $\left(\mathrm{IC}_{50} 30-50 \mathrm{nM}\right)$ and $\mathrm{M}_{5} \mathrm{~L}_{4}$ in the $\mu \mathrm{M}$ range $\left(\mathrm{IC}_{50} 3-16 \mu \mathrm{M}\right)$. We therefore may conclude that the mannosides do not display any species difference or cell-type difference in their affinities towards the mannose receptor.

The large difference in affinity of the two mannosides $M_{6} L_{5}$ and $M_{5} L_{4}$ is in line with the results obtained by other groups. Synthetic lysine-based cluster mannosides with two to four mannose residues had affinities in the $\mathrm{mM}$ to $\mu \mathrm{M}$ range towards isolated macrophages, ${ }^{26,27}$ whereas inhibitors with polymannose structures like mannose ${ }_{48}$-BSA and mannose ${ }_{104}$-polylysine had affinities for macrophages in the $\mathrm{nM}$ range. ${ }^{28,29}$ Using isolated hybrid and high-mannose type oligosaccharides, it was found that oligosaccharides with tri-antennary mannose residues are endocytosed by rat liver endothelial cells with an affinity of 60-600 $\mathrm{nM}$, whereas oligosaccharides with di-antennary mannose residues are not detectably endocytosed. ${ }^{30}$ The mannose receptor is involved in the uptake of antigen by monocytederived dendritic cells. ${ }^{31}$ It was reported that high-mannose type oligosaccharides with di- or triantennary mannose residues inhibit antigen uptake in the $\mu \mathrm{M}$ range, whereas longer tri-antennary oligosaccharides inhibit antigen uptake in the $\mathrm{nM}$ range. ${ }^{32}$ These data all indicate that, for binding to the mannose receptor with $\mathrm{nM}$ affinity, the ligand must contain multiple mannose residues located at some distance from each other. 
The mannose receptor contains 8 carbohydrate recognition domains (CRD). ${ }^{33}$ It was found that the receptor has a high affinity for mannan $(\mathrm{Ki} 110 \mathrm{nM}) .{ }^{34}$ When truncated receptor forms were expressed it was concluded that CRD 4,5 and 7 are essential for the high affinity binding ( $\mathrm{nM}$ range) of mannan, because mannan has a much lower affinity ( $\mu \mathrm{M}$ to $\mathrm{mM}$ range) for mutant receptors lacking one of these CRDs. ${ }^{34,35}$ It was also found that CRD 4 is essential for efficient endocytosis because receptor variants with CRD 5-8 have a much lower endocytosis rate than receptors with CRD $4-8 .{ }^{34}$

The above-mentioned differences in affinity for the mannose receptor of mannosides with a different chain length and the differences of the mannan affinity for various truncated mannose receptors indicates that the chain length of the mannoside determines the number of CRDs it can bind to, and, thereby, the affinity of the ligand for the mannose receptor. Our results suggested that t-PA and $M_{6} L_{5}$ had the proper configuration to bind with high affinity to the mannose receptor expressed on cells. Because the CRD 4,5 and 7 are essential for $\mathrm{nM}$ binding affinity to the receptor, we hypothesize that one molecule of t-PA or $M_{6} L_{5}$ binds simultaneously to the mannose receptor CRD 4,5 and 7, which results in high affinity binding. It is possible that the cluster mannoside $M_{5} L_{4}$ is too short and one molecule of mannoside may only bind to two out of three CRDs which results in a much lower binding affinity.

We compared our in vitro data with in vivo data. In rats, the clearance of mutant t-PA (point mutation) which lacks the oligomannose residue is about $57 \%$ compared to normal glycosylated t-PA. ${ }^{36}$ This is similar to the observed inhibition of t-PA clearance with the highest dose of $M_{6} L_{5}$ we used. When the inhibition by $0.3 \mathrm{mg} \mathrm{M} \mathrm{L}_{6}$ is considered to be maximal (100\%), the observed inhibition of mannose receptor mediated clearance with $0.3 \mathrm{mg} \mathrm{M}_{5} \mathrm{~L}_{4}$ is $66 \%$, and, with $0.03 \mathrm{mg} \mathrm{M}_{6} \mathrm{~L}_{5}$, it is $81 \%$. When we assume that the mannosides are maximally distributed over the total body fluid (approximately $50 \mathrm{ml}$ ) and minimally only in plasma (approximately $8 \mathrm{ml}$ ) the mannosides reach plasma concentrations as shown in table 1. Within this estimated plasma concentration range of the mannosides the degradation of t-PA by cells would have been inhibited with $M_{5} L_{4}$ by $44 \%$ to $56 \%$, with $M_{6} L_{5}$ (dose $0.03 \mathrm{mg}$ ) by $80 \%$ to $91 \%$, and with $M_{6} L_{5}$ (dose $0.3 \mathrm{mg}$ ) by $96 \%$ to $99 \%$. This analysis suggests that the mannose receptor functioning in vitro on isolated rat liver endothelial cells and human macrophages is comparable to and representative of the functioning of the mannose receptor in vivo in the rat.

The mannose receptor also plays a role in the immune system in antigen uptake by antigen-presenting cells. ${ }^{31}$ and in the uptake of intracellular parasites such as Leishmania donovani, ${ }^{37}$ Tryponosoma cruzi.

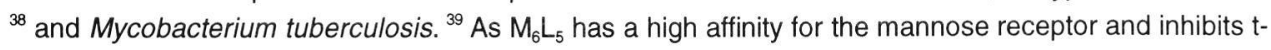
PA binding, it may also be used to inhibit the uptake of antigens or pathogens. Furthermore $M_{6} L_{5}$ could be a good candidate for drug targeting towards mannose receptor-expressing cells. ${ }^{40,41}$ Further studies are required to substantiate these potential therapeutic applications of the high affinity mannose receptor ligand $\mathrm{M}_{6} \mathrm{~L}_{5}$.

In conclusion, we demonstrate that, as in the bovine and rat liver, the mannose receptor is present on liver endothelial cells and Kupffer cells in human liver. The newly. synthesized cluster mannoside $M_{6} L_{5}$ inhibits mannose receptor t-PA binding, uptake and degradation with high affinity (unlike smaller cluster mannosides) on both rat and human cells. t-PA is cleared mainly by the liver in both species. $M_{6} L_{5}$ is a potent inhibitor of mannose receptor-mediated t-PA clearance in the rat, and we expect that it is capable of inhibiting the mannose receptor-mediated t-PA clearance in man to a similar extent. 


\section{ACKNOWLEDGEMENTS}

We wish to thank Dr. E. Barbé, A. van Leeuwen and Dr. J. Lindeman (Department of Pathology, Slotervaart Hospital, Amsterdam) for the immunohistochemistry of the liver. This project was financed by grant no. 90.294 and no. M93.001 from the Netherlands Heart Foundation.

\section{REFERENCES}

1 Bachmann F. Fibrinolytic agents. Fibrinolysis 1995;9,Suppl.1:9-15.

2 Binder BR. Physiology and pathophysiology of the fibrinolytic system. Fibrinolysis 1995;9,Suppl.1:3-8.

3 Collen D. Fibrin-selective thrombolytic therapy for acute myocardial infarction. Circulation 1996;93:857-865.

4 Spellman MW, Basa LJ, Leonard CK, Chakel JA, O'Connor JV, Wilson S, Van Halbeek H. Carbohydrate structures of human tissue-type plasminogen activator expressed in Chinese hamster ovary cells. J Biol Chem 1989;264:14100-14111.

5 Kuiper J, Otter M, Rijken DC, van Berkel ThJC. Characterization of the interaction in vivo of tissue-type plasminogen activator with liver cells. J Biol Chem 1988;263:18220-18224.

6 Brommer EJ, Derkx FH, Schalekamp MA, Dooijewaard G, van de Klaauw MM. Renal and hepatic handling of endogenous tissue-type plasminogen activator (t-PA) and its inhibitor in man. Thromb Haemost 1988;59:404-411.

7 Otter M, Kuiper J, Bos R, Rijken DC, van Berkel ThJC. Characterization of the interaction both in vitro and in vivo of tissue-type plasminogen activator ( $\mathrm{t}-\mathrm{PA}$ ) with rat liver cells. Biochem J 1992;284:545-550.

8 Warshawsky I, Bu G, Schwartz AL. 39-kD protein inhibits tissue-type plasminogen activator clearance in vivo. $\mathrm{J}$ Clin Invest 1993;92:937-944.

9 Narita M, Bu G, Herz J, Schwartz AL. Two receptor systems are involved in the plasma clearance of tissuetype plasminogen activator (t-PA) in vivo. J Clin Invest 1995;96:1164-1168.

10 Biessen EAL, van Teijlingen $M$, Vietsch $H$, BarrettBergshoeff MM, Bijsterbosch MK, Rijken DC, van Berkel ThJC, Kuiper J. Antagonists of the mannose receptor and the LDL receptor-related protein dramatically delay the clearance of tissue-type plasminogen activator. Circulation 1997;95:46-52

11 Zito RA, Reid PR. Lidocaine kinetics predicted by indocyanine green clearance. $N$ Engl $J$ Med 1987;298:1160-1163.

12 De Boer A, Kluft C, Kroon JM, Kasper FJ, Schoemaker HC, Pruis J, Breimer DD, Soons PA, Emeis JJ, Cohen AF. Liver blood flow as a major determinant of the clearance of recombinant human tissue-type plasminogen activator. Thromb Haemost 1992;67:83-87.

13 De Boer A, Kluft C, Dooijewaard G, Kasper FJ, Kroon JM, Breimer DD, Stiekema JC, Cohen AF. Influence of heparin and a low molecular weight heparinoid on specific endogenous and exogenous fibrinolytic factors during rest and exercise. Thromb Haemost 1992;68:550-555.

14 Nooman F, Braat EAM, Rijken DC Degradation of tissuetype plasminogen activator (t-PA) by human monocyte derived macrophages is mediated by the mannose receptor and by the low density lipoprotein-related protein (LRP) Blood 1995;86:3421-3427. Chapter 2 of this thesis.

15 Moestrop SK, Gliemann J, Pallesen G. Distribution of the $\alpha_{2}$-macroglobulin receptor/ow density lipoprotein receptorrelated protein in human tissues. Cell Tissue Res. 1992;269:375-382.

16 Praaning-van Dalen DP, de Leeuw AM, Brouwer A, Knook $\mathrm{DL}$. Rat liver endothelial cells have a greater capacity than Kupffer cells to endocytose $\mathrm{N}$-acetylglucosamine- and mannose- terminated glycoproteins. Hepatology 1987;7:672-679.

17 Messner DJ. The mannose receptor and the cationdependent form of mannose-6-phosphate receptor have overlapping cellular and subcellular distributions in liver. Arch Biochem Biophys 1993;306:391-401.

18 Otter M, Zockova P, Kuiper J, van Berkel ThJC, BarrettBergshoeff MM, Rijken DC. Isolation and characterization of the mannose receptor from human liver potentially involved in the plasma clearance of tissue-type plasminogen activator. Hepatology 1992;16:54-59.

19 Biessen EAL, Noorman F, van Teylingen M, Kuiper J, Barrett-Bergshoeff MM, Rijken DC, Bijsterbosch MK, van Berkel ThJC. (1996) Design of cluster mannosides as high affinity ligands for the human mannose receptor. $\mathrm{J}$ Biol Chem 1996;271:28024-28030. Chapter 6 of this thesis.

20 Herz J, Goldstein JL, Strickland DK, Ho YK, Brown MS. 39-kDa protein modulates binding of ligands to low density lipoprotein receptor-related protein/ $\alpha 2$-macroglobulin receptor. J Biol Chem 1991;266:21232-21238.

21 Barrett-Bergshoeff MM, Noorman F, Bos R, Rijken DC. Monoclonal antibodies against the human mannose receptor that inhibit the binding of tissue-type plasminogen activator. Thromb Haemostas 1997;77:718-24. Chapter 3 of this thesis.

22 Noorman F, Braat EAM, Barrett-Bergshoeff MM, Barbé E, van Leeuwen A, Lindeman J, Rijken DC. Monoclonal antibodies against the human mannose receptor as a specific marker in flow cytometry and immunohistochemistry for macrophages. J Leukocyte Biol 1997;61:63-72. Chapter 4 of this thesis.

23 Cordell JL, Falini B, Erber WN, Ghosh AK, Abdulaziz Z, Mc Donald S, Pulford KAF, Stein H, Mason DY. 
Immunoenzymatic labeling of monoclonal antibodies using immune complexes of alkaline phosphatase and monoclonal ant-alkaline phosphatase (APAAP complexes). $\mathrm{J}$ Histochem Cytochem 1984;32:219-223

24 Nagelkerke JF, Barto KP, van Berkel ThJC. in vivo and in vitro uptake and degradation of acetylated low density lipoprotein by rat liver endothelial, Kupffer and parenchymal cells. J Biol Chem 1983;258:12221-12227.

25 Pulford KAF, Rigney KJ, Micklem KJ, Jones M, Stross WP, Gatter KC, Mason DY. KP1: a new monoclonal antibody that detects a monocyte/macrophage associated antigen in routinely processed tissue sections. J Clin Pathol 1989;42:414-421.

26 Ohsumi Y, Hoppe CA, Ogawa T, Lee YC. Enhancement of macromolecular ligand binding by rabbit alveolar macrophages by mannose oligosaccharides and related compounds. Arch Biochem Biophys 1988;260:241-249.

27 Robbins JC, Lam MH, Stripp CS, Bugianesi RL, Ponpipom $M M$, Shen TY Synthetic glycopeptide substrates for receptor-mediated endocytosis by macrophages. Proc Nat Acad Sci 1981;12:7294-7298.

28 Hoppe CA, Lee YC. The binding and processing of mannose-bovine serum albumin derivatives by rabbit alveolar macrophages. Effect of sugar density. J Biol Chem 1983;258:14193-14199.

29 Hoppe CA, Lee YC. Accumulation of a nondegradable mannose ligand within rabbit alveolar macrophages. Receptor reutilization is independent of ligand degradation. Biochemistry 1984;23:1723-1730.

30 Maynard Y, Baenziger JU. Oligosaccharide specific endocytosis by isolated rat hepatic reticuloendothelial cells. J Biol Chem 1981;256:8063-8068.

31 Sallusto $F$, Cella M, Danieli C, Lanzavecchia A. Dendritic cells use macropinocytosis and the mannose receptor to concentrate macromolecules in the major histocompatibility complex class II compartment: Downregulation by cytokines and bacterial products. $J$ Exp Med 1995;182:389-400.

32 Muchmore AV, Sathyamoorthy N, Decker J, Sherblom AP.
Evidence that specific high-mannose oligosaccharides can directly inhibit antigen-driven T-cell responses. J Leukocyt Biol 1990;48:457-464.

33 Taylor ME, Conary JT, Lennartz MR, StahI PD, Drickamer $K$. Primary structure of the mannose receptor contains multiple motifs resembling carbohydrate-recognition domains. J Biol Chem 1990;265:12156-12162.

34 Taylor ME, Bezouska K, Drickamer K. Contribution to ligand binding by multiple carbohydrate-recognition domains in the macrophage mannose receptor. J Biol Chem 1992;267:1719-1726.

35 Taylor ME, Drickamer K. Structural requirements for high affinity binding of complex ligands by the macrophage mannose receptor. J Biol Chem 1993;268:399-404.

36 Pâques EP, Just $M$, Reiner $G$, Römisch $J$. Pharmacological and pharmacokinetic properties of a deglycosylated mutant of the tissue-type plasminogen activator expressed in CHO cells. Fibrinolysis 1992;6:125130.

37 Chakraborty P, Das PK. Role of mannose $/ \mathrm{N}$ acetylglucosamine receptors in blood clearance and cellular attachment of Leishmania Donovani. Mol Biochem Parasitol 1988;28:55-62.

38 Kahn S, Wleklinski M, Aruffo A, Farr A, Coder D, Kahn M. Trypanosoma cruzi amastigote adhesion to macrophages is facilitated by the mannose receptor. J Exp Med 1995;182:1243-1258.

39 Schlesinger LS, Hull SR, Kaufman TM. Binding of the terminal mannosyl units of lipoarabinomannan from a virulent strain of Mycobacterium tuberculosis to human macrophages. J Immunol 1994;152:4070-4079.

40 Chakraborty P, Bhanduri AN, Das PK. Sugar receptor mediated drug delivery to macrophages in the therapy of experimental visceral leishmaniasis. Biochem Biophys Res Comm 1990;166:404-410.

41 Ferkol T, Perales JC, Mularo F, Hanson RW. Receptormediated gene transfer into macrophages. Proc Nat Acad Sci 1996;93:101-105. 


\section{CHAPTER 8}

Inhibition of mannose receptor-mediated clearance of tissue-type plasminogen activator (t-PA) by dextran: a new explanation for its antithrombotic effect.

F. Noorman, M.M. Barrett-Bergshoeff, M. Bekkers, J.J. Emeis and D.C. Rijken

Gaubius Laboratory, TNO Prevention and Health, Leiden, The Netherlands

Reproduced from

Thrombosis and Haemostasis; 1997, in press 


\section{SUMMARY}

Dextran is used during surgery as a prophylactic agent to prevent deep venous thrombosis. Recently it has been shown that dextran increases t-PA plasma concentrations in patients. As dextran is a potential ligand for the mannose receptor, we studied whether this glucose-polymer would be able to inhibit mannose receptor-mediated clearance of $t-P A$.

In this report we show that dextran 40 and dextran 70 were able to inhibit t-PA binding to the isolated human mannose receptor $\left(\mathrm{IC}_{50} 14\right.$ and $4 \mathrm{mg} / \mathrm{ml}$, respectively). Both glucose-polymers inhibited mannose receptor-mediated t-PA degradation by human monocyte-derived macrophages in vitro $\left(\mathrm{IC}_{50} 7\right.$ and $2 \mathrm{mg} / \mathrm{ml}$, respectively). The $\alpha_{2}$-macroglobulin receptor/ low density lipoprotein receptor-related protein (LRP)-mediated t-PA degradation by the macrophages was not affected by dextran. During and after a 45-min infusion of dextran 70 (Macrodex) in rats, in plasma endogenous t-PA concentrations increased to $162 \pm 33 \%$ and $122 \pm 35 \%$ respectively. The plasma clearance of a bolus injection of exogenous t-PA was decreased by $33 \pm 9 \%$ in the same rats.

We conclude that dextran inhibits mannose receptor-mediated t-PA clearance. The inhibition of t-PA clearance during dextran infusion results in increased endogenous t-PA plasma concentrations. Increased t-PA concentrations present during thrombus formation are known to increase thrombus lysability. Thus the inhibition of t-PA clearance can contribute to the antithrombotic effect of dextran.

\section{INTRODUCTION}

Tissue-type plasminogen activator (t-PA) is a serine protease that activates fibrinolysis by converting plasminogen into plasmin, which cleaves fibrin into soluble degradation products. ${ }^{1,2}$ Because of its fibrin selective action, t-PA is successfully used for thrombolytic therapy, for instance after myocardial infarction. ${ }^{3}$ Recombinant t-PA is a glycoprotein which contains a single high mannose-type and one or two complex-type oligosaccharides. ${ }^{4}$ It is rapidly cleared from plasma by the mannose receptor and the $\alpha_{2}$-macroglobulin receptor/ low density lipoprotein receptor-related protein (LRP).$^{5-7}$

Previously we found that synthesized cluster mannosides are able to inhibit the binding of t-PA to the isolated mannose receptor, ${ }^{8}$ to inhibit mannose receptor-mediated degradation by rat and human cells (Noorman et al. Hepatology 1997, in press), and to inhibit the clearance of t-PA in the rat. ${ }^{7}$ We wanted to know whether an inhibitor of mannose receptor-mediated t-PA degradation would increase the plasma concentrations of endogenous t-PA in man and thereby prevent thrombosis in man. For this we searched the literature for potential ligands/inhibitors of the mannose receptor which have been shown to increase plasma t-PA concentrations in man.

Dextran is a potential ligand for the mannose receptor expressed on monocyte-derived immature dendritic cells. ${ }^{9}$ It is a neutral polysaccharide, which is synthesized from saccharose by a number of bacterial species of the family of the Lactobacillae. It consists of glucose units linked together by alpha 1-6 bonds, and at intervals of about 20 glucose units, short side branches are attached to the main chain by alpha 1-3 linkages. ${ }^{10}$ By partial hydrolysis dextran is made with mean molecular weights of 40,000 (Rheomacrodex or dextran 40) or 70,000 (Macrodex or dextran 70). These dextrans are clinically used as plasma volume expanders for the efficient resuscitation from haemorrhagic hypotension and as a blood substitute in surgery. ${ }^{11,12}$ It is found that dextran is also effective as a prophylactic agent during 
surgery to prevent deep venous thrombosis. ${ }^{13-16}$ Recently it has been shown that t-PA antigen in plasma was increased during dextran infusions in surgical patients by an unknown mechanism. ${ }^{17}$

Since dextran is a potential ligand of the mannose receptor, we hypothesized that the increased $t-P A$ concentrations might have been caused by inhibition of mannose receptor-mediated t-PA clearance. In the present study we tested whether t-PA binding to the isolated human mannose receptor is inhibited by therapeutic concentrations of dextran. We also tested the effect of dextran on t-PA degradation mediated by the mannose receptor and LRP expressed on human macrophages, an in vitro model for the plasma t-PA clearance by the liver. ${ }^{18}$ Finally we compared the effect of $6 \%$ dextran 70 in $0.9 \% \mathrm{NaCl}$ infusion with the effect of $0.9 \% \mathrm{NaCl}$ infusion on the plasma concentration of endogenous t-PA and on the clearance of a bolus injection of exogenous t-PA in vivo in the rat.

\title{
MATERIALS AND METHODS
}

\begin{abstract}
Materials
N-hydroxysuccinimide-biotin (NHS-biotin, Zymed Laboratories Inc., South San Francisco, CA, USA), highly activated polyvinyl chloride microtitre plates (Micronic b.v., Lelystad, The Netherlands), alkaline phosphatase-conjugated streptavidine (Amersham, Buckinghamshire, UK), and p-nitrophenyl phosphate (Sigma, St. Louis, MO, USA) were used for the immobilised mannose receptor assay. Human $\mathrm{AB}^{+}$serum, and thrombocyte-poor pooled buffy coats from healthy donor blood (pooled from 5 donors with the same blood type combined, and serum added to preserve the cells), were obtained from the Red Cross Blood Bank (The Hague and Leiden, The Netherlands). Lymphoprep ${ }^{\mathrm{TM}}$ (Nycomed Pharma AS, Oslo, Norway) with a density of $1.077 \mathrm{~g} / \mathrm{ml}$ was used for density gradient centrifugation. Heparin (Leo Pharmaceutical Products, Ballerup, Denmark), cell culture medium M199 (Flow Laboratories, Irvine, UK), Penicillin/Streptomycin (Pen/strep, Boehringer Mannheim, Mannheim, Germany), and sterile buffers were used to isolate and culture the monocytes. Dexamethasone was purchased from Sigma Chemical Co. (St.Louis, MO, USA). Tissue-type plasminogen activator ( $t-P A)$, was purified from a recombinant human melanoma cell culture ${ }^{19}$ by Dr. J.H. Verheijen of our laboratory. Recombinant t-PA (Actilyse) was obtained from Boehringer Ingelheim (Ingelheim, Germany). Bovine serum albumin (BSA) fraction $V$ and mannan extracted from Saccharomyces cerevisiae, prepared by the cetavlon method were obtained from the Sigma Chemical Co. (St.Louis, MO, USA). The fusion protein of glutathione-S-transferase and $\alpha_{2}$-macroglobulin receptor-associated protein (GST-RAP) was prepared by Dr. J. Kuiper (Sylvius Laboratory, Leiden) using the Salmonella japonicum glutathione-Stransferase (GST)-RAP expression plasmid ${ }^{20}$ (kindly provided by Dr. J.Herz, University of Texas, Southwestern Medical Center, Dallas). Dextran T40 and Dextran T70 and Macrodex ( $6 \%$ Dextran 70 in $0.9 \% \mathrm{NaCl}$ ) were obtained from Pharmacia Fine Chemicals AB (Uppsala, Sweden).
\end{abstract}

\section{Inhibition of t-PA binding to the immobilised mannose receptor.}

Melanoma t-PA $(0.1 \mathrm{mg} / \mathrm{ml})$ was dialysed against $0.1 \mathrm{M} \mathrm{NaHCO}_{3}, 0.01 \%(\mathrm{~V} / \mathrm{V})$ Tween $80, \mathrm{pH} 8.4$ and incubated with NHS-biotin at room temperature for 3 hours at molar ratio 1:200. After incubation biotinylated-t-PA (biot-t-PA) was dialysed against $20 \mathrm{mM} \mathrm{Tris/HCl,}$ $150 \mathrm{mM} \mathrm{NaCl}, 0.01 \%(\mathrm{v} / \mathrm{v})$ Tween $80, \mathrm{pH} 7.4$. Mannose receptor was isolated and purified from human placenta on a mannosylatedalbumin-Sepharose column. ${ }^{21,22}$ The receptor was adsorbed overnight at $4 \mathrm{C}$ to microtitreplates in $20 \mathrm{mM}$ Tris/ $\mathrm{HCl}$ buffer, $150 \mathrm{mM}$ $\mathrm{NaCl}, 5 \mathrm{mM} \mathrm{CaCl}, \mathrm{pH}$ 7.4. The wells were incubated for $0.5 \mathrm{~h}$ at room temperature with binding buffer $(20 \mathrm{mM} \mathrm{Tris} / \mathrm{HCl}, \mathrm{pH} 7.4$ containing $0.5 \%(\mathrm{v} / \mathrm{V})$ Tween $80,150 \mathrm{mM} \mathrm{NaCl}, 5 \mathrm{mM} \mathrm{CaCl}$, and $1 \mathrm{mg} / \mathrm{ml} \mathrm{BSA}$ ). The immobilised receptor was incubated with varying concentrations of inhibitor in binding buffer for $0.5 \mathrm{~h}$. Subsequently a nonsaturating concentration of biot-t-PA (100 ng/ml, final concentration) was added and the mixture was incubated at room temperature for $2 \mathrm{~h}$. Bound biot-t-PA was quantified by incubation at room temperature for $1 \mathrm{~h}$ with alkaline phosphatase-conjugated streptavidine. Between each incubation step the wells were washed 3 times with binding buffer. Bound conjugate was detected by measuring the conversion rate of the chromogenic substrate p-nitrophenyl phosphate at $25^{\circ} \mathrm{C}$. The results were corrected for non-specific binding obtained in wells which were "coated" with buffer without mannose receptor.

\section{Monocyte isolation and cultivation.}

Monocytes were isolated from pooled human buffy coats as described earlier. ${ }^{18}$ Buffy coat (100 ml) was diluted with $180 \mathrm{ml}$ phosphate buffered saline $\left(2.7 \mathrm{mM} \mathrm{KCl}, 137 \mathrm{mM} \mathrm{NaCl}, 8.1 \mathrm{mM} \mathrm{Na}_{2} \mathrm{HPO}_{4}, 1.46 \mathrm{mM} \mathrm{KH}_{2} \mathrm{PO}_{4}, \mathrm{pH} 7.4\right)$ containing 10 units/ml heparin. Using density gradient centrifugation with Lymphoprep ${ }^{\top \mathrm{M}}$, routinely 5 to $10 \times 10^{8}$ cells were obtained. These cells were resuspended in culture medium (M199 containing $10 \mathrm{mg} / \mathrm{ml}$ glutamine, $50 \mathrm{U} / \mathrm{ml}$ penicillin, $50 \mu \mathrm{g} / \mathrm{ml}$ streptomycin) and $2.5 \times 10^{6}$ cells/well were seeded in 24 wells culture plates. After one hour the non-adherent cells were removed with medium, and cells were cultured in culture medium containing $0.1 \mu \mathrm{g} / \mathrm{ml}$ dexamethasone and $10 \%(\mathrm{~V} / \mathrm{N})$ human $\mathrm{AB}^{+}$serum. After 2 days the monocytes were 
differentiated to macrophages and used for degradation studies.

\section{Degradation of ${ }^{125}$ I-t-PA by human macrophages.}

Recombinant $t$-PA was labelled with ${ }^{125} \mathrm{I}$ using the iodogen method. ${ }^{18}$ The macrophages were washed (3x with PBS containing 0.9 $\mathrm{mM} \mathrm{CaCl}, 0.5 \mathrm{mM} \mathrm{MgCl}_{2}, 10 \mathrm{mg} / \mathrm{ml} \mathrm{BSA}, \mathrm{pH} 7.4,4^{\circ} \mathrm{C}$ ), and incubated with $17 \mathrm{nM}^{125} \mathrm{l}$-t-PA with or without $100 \mathrm{nM}$ GST-RAP and inhibitor in $300 \mu \mathrm{M} 199,10 \mathrm{mg} / \mathrm{ml} \mathrm{BSA}, 0.01 \%(\mathrm{~V} / \mathrm{V})$ Tween 80 , at $37^{\circ} \mathrm{C}$ in $5 \% \mathrm{CO}_{2} / 95 \%$ air. After one hour of incubation, cell media were collected and trichloroacetic acid (TCA) was added (final conc. $10 \%$ w/v). Non-degraded ${ }^{125}$ I-t-PA was precipitated by centrifugation $\left(10 \mathrm{~min} 15000 \mathrm{~g}\right.$ ). To eliminate the possibility that the cells might deiodinate rather than degrade ${ }^{125}$ I-t-PA, free ${ }^{125} \mathrm{I}$ was extracted. To the $500 \mu \mathrm{l} \mathrm{TCA}$ soluble supernatant obtained, $5 \mu \mathrm{l} 400 \mathrm{mg} / \mathrm{ml} \mathrm{Kl}$ and $25 \mu_{\mathrm{l}} \mathrm{H}_{2} \mathrm{O}_{2} 30 \%(\mathrm{v} / \mathrm{v}$ ) were added. After 5 minutes the free iodine was extracted with $800 \mu \mathrm{l}$ chloroform. The radioactivity of the remaining ${ }^{125}$-tyrosine (and possibly ${ }^{125}$ I-peptides) in the upper layer $\left(5 \mathrm{~min} 15000 \mathrm{~g}\right.$ ) representing degraded ${ }^{125} \mathrm{I}$-t-PA was determined. Data were corrected for radioactivity of the medium incubated in wells without cells.

\section{The effect of dextran infusion in vivo in the rat.}

Male Wistar rats $(300 \mathrm{~g})$ were anaesthetised with Nembutal $(1 \mathrm{ml} / \mathrm{kg}$ i.p.) and Hypnorm/aqua $(25 \mu \mathrm{l} / \mathrm{rat}$ i.m.). The arteria carotis and the vena femoralis were canulated with heparinized canules. A blood sample was taken from the a. carotis, and $2 \mathrm{ml} \mathrm{of} 0.9 \% \mathrm{NaCl}$ or $6 \%$ dextran 70 in $0.9 \% \mathrm{NaCl}$ (Macrodex) was infused via the vena femoralis in 45 minutes. Samples of blood were taken after $25 \mathrm{~min}$ and $45 \mathrm{~min}$. Thereafter $500 \mu \mathrm{g} / \mathrm{kg}$ bw. recombinant t-PA was injected via the vena femoralis. Blood samples were taken on time $=1,2$, $3,4,5,7,10$ and 15 minutes after injection. Haematocrit was measured at $0,25,45$ and 60 min. All blood samples were diluted with $3.8 \%(\mathrm{~W} / \mathrm{v})$ trisodium citrate. $2 \mathrm{H}_{2} \mathrm{O}$ (1 vol. to $9 \mathrm{vol}$. blood), kept on ice during the experiment, centrifugated (10 min $\left.2000 \mathrm{~g}\right)$, and plasma was frozen to $-20{ }^{\circ} \mathrm{C}$ until analysis. Rat endogenous t-PA concentrations were measured using an Elisa specific for rat $t-P A,{ }^{23}$ and recombinant t-PA was measured using an Elisa specific for human t-PA. ${ }^{24}$

\section{Analysis of inhibition curves and t-PA clearance}

Inhibition of the binding or degradation of labelled-t-PA will lead to a decreased value for labelled-t-PA binding or degradation expressed as a percentage of control. Isolated mannose receptor or cells were incubated with a concentration range of inhibitor and a nonsaturating concentration of labelled t-PA, the binding or degradation was measured and corrected for non-specific binding or degradation. The resulting inhibition curves were fitted as a sigmoid curve using nonlinear regression analysis with the computer program GraphPAD (ISI Software, Philadelphia, PA, USA), yielding half maximal inhibitory concentration (IC $\mathrm{C}_{50}$ ), and Hill-slopes. "Goodness of fit" was assessed by evaluating the actual distance of the measurements from the fitted line (no weighing).

Endogenous t-PA concentrations were corrected for the citrate dilution and the haematocrit measured at the corresponding sample time. The plasma concentration of the injected recombinant t-PA at zero time was calculated using the previously determined blood volume $\left(7.3 \mathrm{ml}\right.$ blood $100 \mathrm{~g}$ rat $\left.{ }^{25}\right)$, the measured haematocrit and the citrate dilution. Using the above-mentioned computer program the t-PA clearance curves were fitted using a two-compartment model. Clearance was calculated by dividing the calculated initial concentration in plasma by the area under the clearance curve calculated from 0 to 15 minutes. Data are expressed as mean \pm standard error of the mean (SEM), and statistical significance of differences was determined using the program SOLO 4.0 (BMDP Statistical software, Los Angeles, CA).

\section{RESULTS}

We tested the effect of dextran and various monosaccharides on the binding of t-PA to the isolated and immobilised human mannose receptor. As shown in Fig 1 the polymers of glucose, dextran 40 and dextran 70 , inhibited t-PA binding with $\mathrm{IC}_{50}$ values of respectively 14 and $4 \mathrm{mg} / \mathrm{ml}$. Though the name of the mannose receptor suggests that it only has an affinity for mannose-containing ligands, the receptor has a lower affinity for other carbohydrates. As shown in Fig $2 \mathrm{D}$-mannose, D-glucose and N-acetyl-Dgalactosamine inhibited $t-P A$ binding with decreasing affinities $\left(\mathrm{IC}_{50}\right.$ respectively 2,7 and $\left.57 \cdot \mathrm{mg} / \mathrm{ml}\right)$. On a weight basis dextran 40 and 70 inhibited t-PA binding with an affinity comparable to that of $D$-glucose. We tested whether dextran was also able to inhibit mannose receptor-mediated degradation by human monocyte-derived macrophages. These cells express the mannose receptor and LRP. ${ }^{18}$ In order to study mannose receptor-mediated degradation we upregulated the mannose receptor using dexamethasone and we used GST-RAP to inhibit LRP-mediated t-PA degradation. ${ }^{18}$ As shown in Fig 3 , the mannose receptor-mediated t-PA degradation is inhibited by dextran 40 and dextran $70\left(\mathrm{IC}_{50}\right.$ respectively 7 and $2 \mathrm{mg} / \mathrm{ml}$ ). 


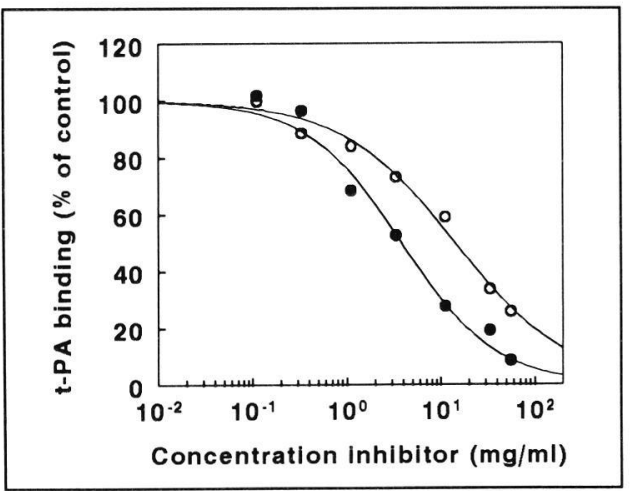

Fig 1 Inhibition of t-PA binding to the isolated human mannose receptor by dextran.

Isolated immobilised human mannose receptor was incubated with biotinylated t-PA and increasing concentrations of dextran. Residual binding was determined and expressed as a percentage of control. Data represent the mean of duplicates, curves were fitted from 100 to $0 \%$. Dextran $70(\bullet)$ or dextran $40(0)$.

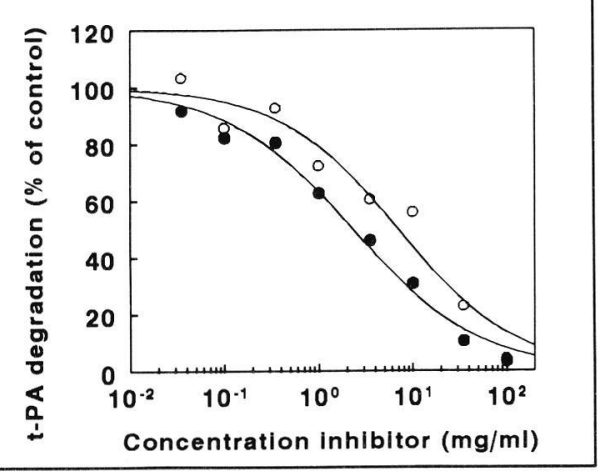

Fig 3 Inhibition of mannose receptor-mediated t-PA degradation by dextran.

Human monocyte-derived macrophages were incubated with radiolabelled $t-P A$ and a range of dextran concentrations in the presence of $100 \mathrm{nM}$ GST-RAP (mannose receptor-mediated degradation). Degradation was determined and expressed as a percentage of control. Data represent the mean of duplicates, curves were fitted from 100 to $0 \%$. Mannan $(1 \mathrm{mg} / \mathrm{ml})$ inhibited tPA degradation for $93.4 \%$. Dextran $70(\bullet)$, dextran $40(0)$.

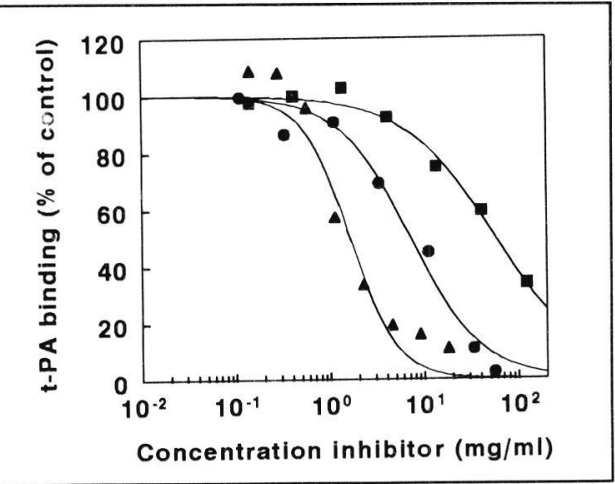

Fig 2 Inhibition of t-PA binding to the isolated human mannose receptor by monosaccharides.

Isolated immobilised human mannose receptor was incubated with biotinylated t-PA and increasing concentrations of monosaccharides. Residual binding was determined and expressed as a percentage of control. Data represent the mean of duplicates and curves were fitted from 100 to $0 \%$. D-mannose $(\mathbf{\Lambda})$, D-glucose (•), N-acetyl-D-galactosamine (घ).

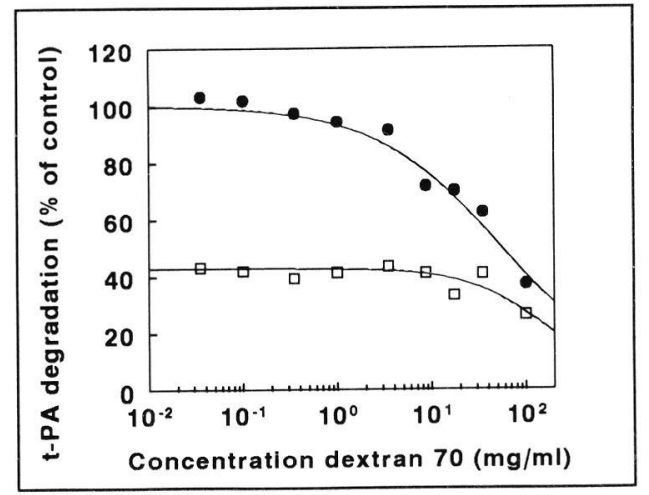

Fig 4 Inhibition of total and LRP-mediated t-PA degradation by dextran 70 .

Human monocyte-derived macrophages were incubated with radiolabelled $\mathrm{t}-\mathrm{PA}$ and a range of dextran 70 concentrations in the absence (total degradation (-)) or presence of $1 \mathrm{mg} / \mathrm{ml}$ mannan (LRP mediated degradation ( $\square$ )). Degradation was determined and expressed as a percentage of control. Data represent the mean of duplicates; curves were fitted from $100 \%$ or from the level obtained in the presence of mannan without dextran to $0 \%$. 
To study whether LRP-mediated degradation by the macrophages was inhibited by dextran we looked at the effect of dextran 70 on total t-PA degradation (mediated by both LRP and the mannose receptor) and on degradation in the presence of an excess of mannan (mediated by LRP). As shown in Fig 4 total degradation was only partially inhibited by dextran 70 at concentrations that inhibited mannose receptormediated degradation completely (Fig 3 ). Dextran 70 did not affect LRP degradation at low and intermediate concentrations, only the highest concentration used $(100 \mathrm{mg} / \mathrm{ml})$ started to inhibit LRPmediated degradation. Therapeutic amounts of dextran 70 reach plasma concentrations of about 10 $\mathrm{mg} / \mathrm{ml}$ directly after infusion, after 5 hours the concentration is reduced to $6 \mathrm{mg} / \mathrm{ml}$. ${ }^{10}$ Figures 3 and 4 shows that at $10 \mathrm{mg} / \mathrm{ml}$ of dextran 70 approximately $60 \%$ of mannose receptor-mediated t-PA degradation was inhibited, while LRP mediated t-PA degradation was not affected.

We tested the effect of dextran 70 infusion on the plasma concentration of endogenous t-PA, and on the clearance of a bolus injection of t-PA in vivo in the rat. A schematic overview of the experiment is shown in Fig 5A. During and after infusion of $\mathrm{NaCl}$ the haematocrit remained at $44 \%$, while in the dextrantreated rats the haematocrit increased during infusion to $54 \%$ ( $t=25 \mathrm{~min}$ ) and then steadily decreased to $49 \%$ ( $t=60 \mathrm{~min}$ ). As shown in Fig $5 \mathrm{~B}$ and Table 1, the endogenous $\mathrm{t}-\mathrm{PA}$ concentration decreased during and after $\mathrm{NaCl}$ infusion, while it increased during and after dextran infusion in most rats. On average the clearance of exogenous t-PA was inhibited for $33 \pm 9 \%$ by dextran $(0.56 \pm 0.07 \mathrm{ml} / \mathrm{min})$ compared to $\mathrm{NaCl}$ treatment $(0.85 \pm 0.07 \mathrm{ml} / \mathrm{min})$ (Fig $5 \mathrm{C}$ ). Both half-lives of t-PA were decreased (see Table 1), while the amount of t-PA cleared in each phase remained the same for both treatments (approximately $70 \%$ was cleared in the $\alpha$ phase, and $30 \%$ in the $B$ phase). The rats treated with dextran that had the highest endogenous t-PA concentrations, were also the rats that had the lowest clearance of exogenous t-PA (Fig 5D). We conclude that our data support the hypothesis that dextran inhibits t-PA clearance in vivo.

Table 1 The effect of dextran on plasma endogenous t-PA concentrations and exogenous t-PA clearance in vivo in the rat.

Summary and significance of the differences between the effect of $0.9 \% \mathrm{NaCl}$ or $6 \%$ dextran 70 in $0.9 \% \mathrm{NaCl}$ infusions (see Fig 5 ) on the endogenous t-PA concentration and exogenous $t-P A$ clearance in the rat. Data are represented as mean $\pm S E M(n=5)$, the probability of difference between $\mathrm{NaCl}$ versus dextran treatment is calculated using the Mann-Whitney test.

\begin{tabular}{|c|c|c|c|}
\hline Parameter & $\mathrm{NaCl}$ infusion & Dextran infusion & Probability value \\
\hline $\begin{array}{l}\text { endogenous } t-P A \\
t=25 \min (\% t=0)\end{array}$ & $53 \pm 6$ & $162 \pm 33$ & 0.009 \\
\hline $\begin{array}{l}\text { endogenous } t-P A \\
t=45 \text { min }(\% t=0)\end{array}$ & $54 \pm 7$ & $122 \pm 35$ & 0.009 \\
\hline $\begin{array}{l}\text { t-PA clearance } \\
(\mathrm{ml} / \mathrm{min})\end{array}$ & $0.85 \pm 0.07$ & $0.56 \pm 0.07$ & 0.047 \\
\hline $\begin{array}{l}\text { t-PA clearance } \\
\text { half-life } \propto(\mathrm{min})\end{array}$ & $0.24 \pm 0.08$ & $0.53 \pm 0.07$ & 0.028 \\
\hline $\begin{array}{l}\text { t-PA clearance } \\
\text { half-life } B \text { (min) }\end{array}$ & $2.3 \pm 0.4$ & $4.1 \pm 0.7$ & 0.117 \\
\hline
\end{tabular}



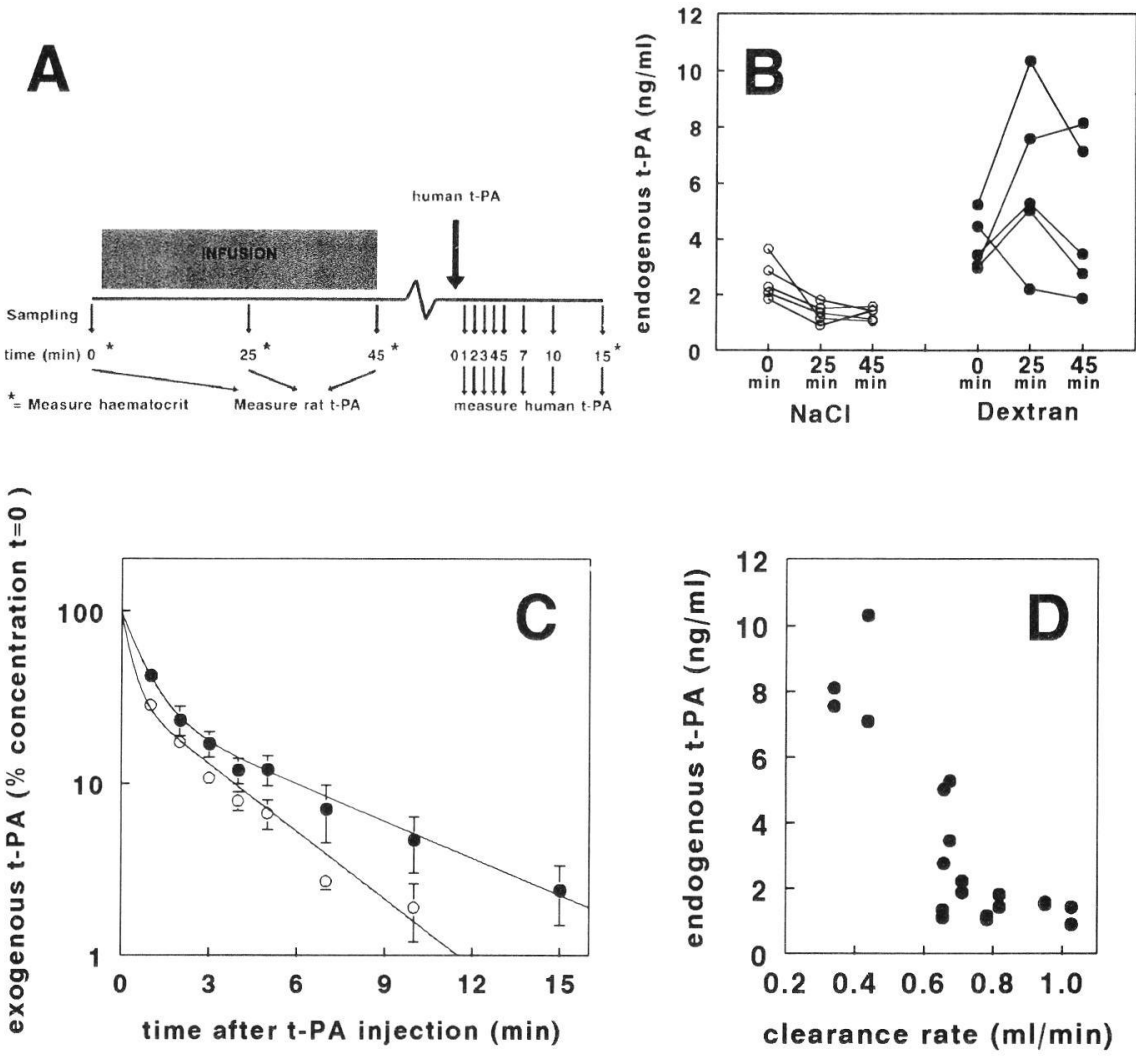

Fig 5 The effect of dextran on plasma endogenous t-PA concentration and exogenous t-PA clearance in vivo in the rat. A schematic overview of the in vivo experiment is shown in Fig $5 A$. Before ( $t=0 \mathrm{~min})$, during $(t=25 \mathrm{~min})$, and after ( $t=45 \mathrm{~min})$ the infusion of $2 \mathrm{ml} 0.9 \% \mathrm{NaCl}(n=5)$ or $2 \mathrm{ml} 6 \%$ dextran 70 in $0.9 \% \mathrm{NaCl}(n=5)$ in the rat, plasma samples were taken and the endogenous t-PA plasma concentration was measured. Data were corrected for the haematocrit and citrate dilution, and are represented in Fig 5B (mean \pm SEM; NaCl-treated rats open circles; dextran treated rats closed circles). After the infusion a bolus injection of $500 \mu \mathrm{g} / \mathrm{kg} \mathrm{bw}$. recombinant t-PA was given. At the time points indicated plasma samples were taken and human t-PA plasma concentration was measured. Data were expressed as a percentage of the calculated initial plasma concentration corrected for haematocrit and citrate dilution $(11.0 \mu \mathrm{g} / \mathrm{ml} \mathrm{NaCl}$-treated rats, $12.2 \mu \mathrm{g} / \mathrm{ml}$ dextran-treated rats) and are shown in Fig 5C (lines: two-compartment model using the average clearance paramenters mentioned in Table 1, NaCl-treated rats (O); dextran-treated rats (-), mean plasma concentrations \pm SEM). The correlation between clearance rates and endogenous $t-P A$ concentration at $t=25$ min and $\mathrm{t}=45 \mathrm{~min}$ of the rats is shown in Fig 5D. 


\section{DISCUSSION}

Dextran has antithrombotic properties when used in vivo in man. ${ }^{13-16}$ The antithrombotic effect of dextran is attributed to decreased coagulation by decreased platelet aggregation and adhesion, and to increased fibrinolysis by influencing fibrin structure. ${ }^{10,13,26,27}$ However when at therapeutic concentrations dextran is added in vitro to normal blood or plasma, there is no reduction in platelet adhesiveness and no increased lysability of in vitro formed thrombi, while in vitro formed thrombi from blood obtained from patients receiving dextran were more easely lysed. ${ }^{10}$ Thus dextran probably affects plasma concentrations of components of the coagulation and/or the fibrinolytic cascade in vivo.

The plasma levels of coagulation factors are not affected more than what would be expected from haemodilution except for the decrease in factor VIII:C and von Willebrand factor plasma concentrations which could contribute to the effects of dextran on platelet function. ${ }^{10,28-30}$ Recently it has been shown that $t-P A$ antigen and t-PA activity were increased during dextran infusions in surgical patients (by 18 and $43 \%$ respectively). PAl-1 activity was decreased by $19 \%$ probably by the increase in t-PA. ${ }^{17}$ These findings are, however, not consistently found. Early studies showed that t-PA antigen as well as PAl-1 activity were significantly increased compared to preoperative values when measured one day after total hip replacement and dextran infusion. ${ }^{23}$ No significant increase of t-PA activity was observed after dextran infusion, ${ }^{28}$ and the desmopressin induced increase of t-PA antigen appeared not to be affected by dextran when studied in volunteers. ${ }^{29}$ Whether these differences in observations were due to a difference in study design (such as blood sampling, patients versus volunteers, or number of participants) remains to be determined.

As dextran has been shown to be a possible ligand of the mannose receptor, ${ }^{9}$ we hypothesized that inhibition of the mannose receptor-mediated t-PA clearance could contribute to the antithrombotic effect of dextran. In this study we tested whether dextran was able to inhibit mannose receptor-mediated t-PA degradation in vitro and in vivo. We showed that dextran inhibited binding of t-PA to the isolated immobilised mannose receptor. We also showed that mannose receptor-mediated t-PA degradation was inhibited (approximately by $60 \%$ ) by dextran at therapeutic concentrations ( $10 \mathrm{mg} / \mathrm{ml}$ ), whereas LRP mediated t-PA degradation was not. It appeared that dextran 70 had a 3 fold higher affinity than dextran 40 (6 fold higher when expressed in molar concentrations). Dextran 40 is clinically used in higher concentrations than dextran $70(10 \%$ and $6 \% \mathrm{w} / \mathrm{v}$ solutions, respectively). The clinical plasma concentrations of dextran 40 are therefore higher, and based on our competition experiments the effects of both dextran forms on the t-PA clearance will be similar in vivo.

In vivo dextran treatment increased the plasma concentration of endogenous t-PA in the rat. This can be caused by stimulation of t-PA release and by inhibition of t-PA clearance. Therefore we also measured in the same rats the clearance of a bolus injection of recombinant t-PA. We found that the dextran treatment inhibited the clearance of exogenous t-PA by about $33 \%$. The half-lives of both the rapid $\alpha$ phase and the slower B-phase were reduced by dextran, as observed previously with other inhibitors of mannose receptor-mediated t-PA clearance ${ }^{6,32}$ 
Dextran reduces thrombus formation and thrombus weight in a venous occlusion rabbit model. ${ }^{33,34}$ Increased t-PA concentrations present during thrombus formation cause increased lysability of thrombi. ${ }^{27,35,36}$ Recently it has been shown that even a doubling of plasma t-PA concentrations (within the physiological t-PA concentration range) is able to significantly reduce thrombus formation in a rat arterial thrombosis model. ${ }^{37}$ Thus the increased t-PA concentrations during dextran infusion could contribute to the antithrombotic effect of dextran.

If partial inhibition of mannose receptor-mediated t-PA clearance already results in increased endogenous plasma t-PA concentrations, thereby reducing the risk of thrombosis in man, complete inhibition would even be more effective. A recently synthesized cluster mannoside with a high affinity for the mannose receptor ${ }^{8}$ was able to fully inhibit mannose receptor-mediated t-PA clearance at plasma concentrations in the $\mu \mathrm{g} / \mathrm{ml}$ range without showing any toxic effect in rats. ${ }^{7}$ Would this compound be more efficient than dextran and be a better agent for preventing deep venous thrombosis in man? Further studies are required to provide evidence for this intriguing possibility.

In conclusion we showed that at therapeutic concentrations dextran is able to inhibit mannose receptor tPA binding and to interfere with mannose receptor-mediated t-PA degradation by cells in vitro. We also showed that in rats dextran increases endogenous t-PA concentrations and inhibits t-PA clearance in vivo. As increased t-PA concentrations present during clot formation increase the thrombus lysability, the increased t-PA concentrations in plasma can contribute to the antithrombotic effect of dextran.

\section{ACKNOWLEDGEMENT}

We wish to thank C.M. van den Hoogen for expert technical assistance. This study was financially supported by grant no. 90.294 from the Netherlands Heart Foundation.

\section{REFERENCES}

1 Bachmann F. Fibrinolytic agents. Fibrinolysis 1995; 9 Suppl 1: 9-15.

2 Emeis JJ, Verheijen JH, Ronday HK, de Maat MPM, Brakman P. Progress in clinical fibrinolysis. Fibrinolysis \& Proteolysis 1997; 11: 67-84

3 Collen D. Fibrin-selective thrombolytic therapy for acute myocardial infarction. Circulation 1996; 93: 857-65.

4 Spellman MW, Basa LJ, Leonard CK, Chakel JA, o'Connor JV, Wilson S, Van Halbeek $H$. Carbohydrate structures of human tissue-type plasminogen activator expressed in Chinese hamster ovary cells. J Biol Chem 1989; 264: 14100-11.

5 Otter M, Kuiper J, Bos R, Rijken DC, van Berkel ThJC. Characterization of the interaction both in vitro and in vivo of tissue-type plasminogen activator (t-PA) with rat liver cells. Biochem J 1992; 284: 545-50.

6 Narita M, Bu G, Herz J, Schwartz AL. Two receptor systems are involved in the plasma clearance of tissuetype plasminogen activator (t-PA) in vivo. J Clin Invest 1995; 96: 1164-8.

7 Biessen EAL, van Teijlingen $M$, Vietsch $H$, BarrettBergshoeff MM, Bijsterbosch MK, Rijken DC, van Berkel ThJC, Kuiper J. Antagonists of the mannose receptor and the LDL receptor-related protein dramatically delay the clearance of tissue-type plasminogen activator. Circulation 1997; 95: 46-52.

8 Biessen EAL, Noorman F, van Teylingen M, Kuiper J, Barrett-Bergshoeff MM, Rijken DC, Bijsterbosch MK, van Berkel ThJC. Lysine-based cluster mannosides that inhibit ligand binding to the human mannose receptor at nanomolar concentration. J Biol Chem 1996; 271: 2802428030. Chapter 6 of this thesis.

9 Sallusto F, Cella M, Danieli C, Lanzavecchia A. Dendritic cells use macropinocytosis and the mannose receptor to concentrate macromolecules in the major histocompatibility complex class II compartment: Downregulation by cytokines and bacterial products. J Exp Med 1995; 182: 389-400.

10 Ảberg $\mathrm{M}$, Hedner $\mathrm{U}$, Bergentz SE. The antithrombotic effect of dextran. Scand J Haematol Suppl 1979; 334: 618.

11 Dubick MA, Wade CEA. Review of the efficacy and safety of $7.5 \% \mathrm{NaCl} / 6 \%$ Dextran 70 in experimental animals and in humans. J Trauma 1994; 36: 323-30.

12 Schött U, Djöstrand U, Thorén T, Berséus O. Three per cent dextran 60 as a plasma substitute in blood component 
therapy. An altemative in surgical blood loss replacement. Acta Anaesthesiol Scand 1985; 29: 767-74.

13 Ljungström KG. The antithrombotic efficacy of dextran. Acta Chir Scand Suppl 1988; 543: 26-30.

14 Clagett GP, Reisch JS. Prevention of venous thromboembolism in general surgical patients. Results of meta-analysis. Ann Surg 1988; 208: 227-40

15 Potyk DK, Tabbarah HJ. The pathogenesis and prevention of thromboembolic complications in patient undergoing total hip replacement. J Gener Int Med 1993; 8: 213-19.

16 Imperiale TF, Speroff TA. Meta analysis of methods to prevent venous thromboembolism following total hip replacement. J A M A 1994; 271: 1781-5.

17 Eriksson M, Saldeen T. Effect of dextran on plasma tissue plasminogen activator ( $\mathrm{t}$-PA) and plasminogen activator inhibitor (PAI-1) during surgery. Acta Anaestesiol Scand 1995; 39: 163-6.

18 Noorman F, Braat EAM, Rijken DC. Degradation of tissuetype plasminogen activator by human monocyte derived macrophages is mediated by the mannose receptor and by the low density lipoprotein-related protein. Blood 1995; 86: 3421-7. Chapter 2 of this thesis.

19 Kluft C, Van Wezel AL, Van der Velden CAM, Emeis JJ, Verheijen $\mathrm{JH}$, Wijngaards $\mathrm{G}$. Large scale production of extrinsic (tissue-type) plasminogen activator from human melanoma cells. In: Advances in biotechnological processes, vol 2. Mizrahi A, Van Wezel AL, eds. Alan R., Liss Inc, New York USA 1983: pp 97-110.

20 Herz J, Goldstein JL, Strickland DK, Ho YK, Brown MS. 39-kDa protein modulates binding of ligands to low density lipoprotein receptor-related protein/ $\alpha 2$-macroglobulin receptor. J Biol Chem 1991; 266: 21232-8.

21 Otter M, Barrett-Bergshoeff MM, Rijken DC. Binding of tissue-type plasminogen activator by the mannose receptor. J Biol Chem 1991; 266: 13931-5.

22 Otter M, Zockova P, Kuiper J, van Berkel ThJC, BarrettBergshoeff MM, Rijken DC. Isolation and characterization of the mannose receptor from human liver potentially involved in the plasma clearance of tissue-type plasminogen activator. Hepatology 1992; 16: 54-9.

23 Emeis JJ, Hoekzema R, Vos AF. Inhibiting interleukin-1 and tumor necrosis factor- $\alpha$ does not reduce induction of plasminogen activator inhibitor type- 1 by endotoxin in rats in vivo. Blood 1995; 85: 115-120.

24 Bos R, Hoegee-de Nobel E, Laterveer R, Meyer P, Nieuwenhuizen $W$. A one- step enzyme immunoassay for the determination of total tissue-type plasminogen activator (t-PA) antigen in plasma. Blood Coagul Fibrinol 1992; 3: 303-307.
25 Rijken DC, Emeis JJ. Clearance of the heavy and light polypeptide chains of human tissue-type plasminogen activator in rats. Biochem J 1986; 238: 643-646

26 Bergqvist D. Dextran and haemostasis. Acta Chir Scand 1982; 148: 633-40.

27 Carr ME, Alving BM. Effect of fibrin structure on plasminmediated dissolution of plasma clots. Blood Coagul Fibrinol 1995; 6: 567-73.

28 Flordal PA, Svensson J, Ljungström KG. Effects of desmopressin and dextran on coagulation and fibrinolysis in healthy volunteers. Thromb Res 1991; 62: 355-64.

29 Lethagen S, Rugarn P, Åberg M, Nilsson IM. Effects of desmopressin acetate (DDAVP) and dextran on hemostatic and thromboprophylactic mechanisms. Acta Chir Scand 1990; 156: 597-602.

30 Battle J, del Rio F, López Fernandez MF, Martin R, López Borrasca A. Effect of dextran on factor VIII/von Willebrand factor structure and function. Thromb Haemostas 1985; 54: 697-9.

31 Eriksson BI, Eriksson E, Gyzander E, Teger-Nilsson AC, Risberg B. Thrombosis after hip replacement. Relationship to the fibrinolytic system. Acta Orthop Scand 1989; 60: 159-63.

32 Lucore CL, Fry ETA, Nachowiak DA, Sobel BE. Biochemical determinants of clearance of tissue-type plasminogen activator from the circulation. Circulation 1988; 77: 906-914.

33 Matthiasson SE, Lindblad B, Matzach T, Holst J, Bergqvist D. Effect of low molecular weight heparin, dextran and their combinations on experimental venous thrombosis in rabbits. Thromb Haemostas 1994; 71: 363-5.

34 Matthiasson SE, Lindblad B, Bergqvist D. Prevention of experimental venous thrombosis in rabbits with low molecular weight heparin, dextran and their combinations, administered before or during induction of venous endothelial trauma. Thromb Res 1994; 6: 655-63.

35 Brommer EJP. The level of extrinsic plasminogen activator ( $t$-PA) during clotting as a determinant of the rate of fibrinolysis: inefficiency of activators added afterwards. Thromb Res 1984; 34: 109-15.

36 Zamarron C, Lijnen HR, Collen D. Influence of exogenous and endogenous tissue-type plasminogen activator on the lysability of clots in a plasma milieu in vitro. Thromb Res 1984; 35: 335-45.

37 Emeis JJ, Bekkers M. Low-dose infusion of tissue-type plasminogen activator (t-PA) prevents arterial thrombosis in a rat thrombosis model: $t-P A$ as antithrombotic agent. Fibrinolysis 1996; 10 Suppl 3: 128. 


\section{CHAPTER 9}

\section{General discussion}

Regulation of tissue-type plasminogen activator concentrations by clearance via the mannose receptor and other receptors.

Femke Noorman and Dingeman C. Rijken

Gaubius Laboratory, TNO Prevention and Health, Leiden, The Netherlands

Reproduced from

Fibrinolysis and Proteolysis; 1997, in press. 


\section{SUMMARY}

This review describes the identity, tissue distribution, ligands and functions of the mannose receptor and other tissue-type plasminogen activator (t-PA) clearance receptors like the low density lipoprotein receptor-related protein (LRP). The receptor binding sites of t-PA and the corresponding t-PA binding sites of the receptors are summarized, and recently developed inhibitors of t-PA clearance are described. The contribution of the receptors to the systemic clearance of t-PA and (patho)physiological conditions that may influence receptor expression, t-PA clearance and plasma t-PA concentrations are evaluated. Furthermore the potential use of mannose receptor inhibitors in thrombolytic and antithrombotic therapy is discussed.

\section{Tissue-type plasminogen activator}

Tissue-type plasminogen activator ( $t-P A)$ is one of the activators that is able to convert plasminogen into plasmin which cleaves fibrin into soluble degradation products. t-PA was purified from uterine tissue and found to be closely similar to the vascular plasminogen activator present in blood and in the human vascular wall. ${ }^{1}$ It was isolated from the culture fluid of a melanoma cell line in 1981 and cloned and expressed in $1983 .{ }^{2}$ High concentrations of active t-PA can rapidly activate the dissolution of blood clots. Infusions of recombinant t-PA are therefore successfully used in thrombolytic therapy. ${ }^{3.5} \mathrm{New}$ fibrinolytic agents such as t-PA mutants are currently in development. ${ }^{4,6}$

$\mathrm{t}-\mathrm{PA}$ is a $69 \mathrm{kDa}$ serine protease consisting of five domains: finger domain, growth factor domain, kringle 1 , kringle 2, and a protease domain. Three potential $\mathrm{N}$-glycosylation sites are present on the molecule, of which each is able to bear an oligosaccharide of a size comparable to that of a kringle domain (recently reviewed ${ }^{7}$ ). The oligosaccharide found on Asn 117 in kringle 1 is a high mannose-type oligosaccharide; Asn 148 in kringle 2 of t-PA may (type I t-PA) or may not (type II t-PA) be glycosylated with a complex-type oligosaccharide; and the protease domain bears a complex-type oligosaccharide on Asn 448. In addition a fucose unit is O-linked to Thr 61 in the growth factor domain of t-PA. Circulating plasma t-PA is synthesized and released by the endothelial cells that line the blood vessels. ${ }^{8}$ The physiological plasma concentration of t-PA is low. Synthesis and blood clearance of t-PA as well as inhibition of $t-P A$ by its inhibitor plasminogen activator inhibitor- 1 (PAI-1) control the activity of t-PA in the blood. ${ }^{9}$ High concentrations of PAl-1 in the blood lead to low t-PA activity. Low t-PA activity is associated with the risk of cardiovascular diseases such as myocardial infarction. ${ }^{9,10}$

Clot dissolution is a highly regulated process. ${ }^{11}$ One intriguing phenomenon is that some coagulation factors (for example thrombin and factor Xa in combination with phospholipids) stimulate the endothelial cells to release large amounts of t-PA. ${ }^{12,13}$ The concentration of active t-PA present during clot formation determines the lysability of the clot afterwards. ${ }^{14,15}$ Recently it has been shown that very low dose t-PA infusions during thrombus formation (resulting in doubling of the physiological concentration of $t-P A$ ) reduces thrombus formation in vivo in the rat. ${ }^{16}$ Instead of low dose infusions of t-PA, other ways to achieve higher active t-PA concentrations for prevention and therapy would be the administration of PAI1 antagonists, ${ }^{17}$ stimulators of t-PA synthesis and release ${ }^{18}$ or t-PA clearance inhibitors.

This report describes the properties and the functioning of the mannose receptor and other clearance receptors. Furthermore, it evaluates their role in the regulation of the t-PA plasma concentration and discusses the potential therapeutic applications of $t-P A$ clearance inhibitors. 


\section{Clearance of $t-P A$}

The clearance of $t-P A$ from the circulation is very rapid. In man both endogenous and recombinant t-PA have half-lives of approximately 5 minutes. ${ }^{19-23}$ The liver is the main organ responsible for the clearance of t-PA. ${ }^{19,21}$ In 1985 it was suggested for the first time that the mannose receptor is involved in the clearance of t-PA. ${ }^{24}$ The first reports providing evidence for this process were published in $1988 .{ }^{25-28}$ The $175 \mathrm{kDa}$ mannose receptor isolated from bovine lung, ${ }^{29}$ from human liver ${ }^{30}$ and from human placenta, ${ }^{31}$ has been shown to bind t-PA. Furthermore polyclonal antibodies against the human mannose receptor are able to inhibit endocytosis of t-PA by rat liver endothelial cells in vitro. ${ }^{32}$ Recently we developed a panel of monoclonal antibodies against the human mannose receptor isolated from placenta. All monoclonal antibodies bind to the $175 \mathrm{kDa}$ human mannose receptor in a Western blot and in an ELISA. Three of these monoclonal antibodies, which recognise the same epitope, are able to inhibit the binding of $\mathrm{t}-\mathrm{PA}$ to the isolated mannose receptor and the mannose receptor-mediated t-PA degradation by human macrophages in culture. ${ }^{33}$

Inhibitors of the mannose receptor, however, only partially inhibit t-PA clearance. ${ }^{26-28}$ After the identification of the mannose receptor as a t-PA clearance receptor, it took another four years before the $\alpha_{2}$-macroglobulin receptor also called the low density lipoprotein receptor-related protein (LRP) was identified as another t-PA clearance receptor. ${ }^{34-37}$ An inhibitor of the LRP also partially inhibited t-PA clearance. ${ }^{38}$ Both the mannose receptor and LRP are about equally involved in the clearance of $t$ $P A .{ }^{39,40}$ Administration of inhibitors of the mannose receptor and the LRP inhibited t-PA clearance each by approximately $60 \%$, whereas a combination of these inhibitors inhibited clearance by approximately $90 \%$ in the rat. ${ }^{40}$

However, it cannot be excluded that besides the mannose receptor and LRP, other receptors were inhibited in these in vivo experiments. The $39 \mathrm{kDa}$ receptor-associated protein (RAP) that was used to inhibit LRP-mediated t-PA clearance, also inhibits ligand binding to other receptors of the LDL receptor gene family such as the very low density lipoprotein (VLDL) receptor, epithelial glycoprotein 330 (gp330), and the low density lipoprotein (LDL) receptor. ${ }^{41}$ Apart from LRP, both the VLDL receptor ${ }^{42}$ and gp330 ${ }^{37}$ also have been shown to bind t-PA at least when complexed to PAl-1 (t-PA-PAl-1). Inhibitors of the mannose receptor-mediated clearance may also inhibit the binding of ligands to other mannose-binding proteins (MBP) like serum amyloid $\mathrm{P}^{43}$ and $\mathrm{MBP}-\mathrm{C}^{44}$ which have a ligand spectrum similar to that of the mannose receptor. It has been shown that serum contains a MBP that inhibits mannose receptor-mediated uptake by liver endothelial cells. ${ }^{45}$ It is however not known whether t-PA binds to MBP.

Although t-PA clearance is already approximately $90 \%$ inhibited by a combination of mannose receptor and LRP inhibitors, other t-PA receptors may have a minor role in t-PA clearance. A fucose receptor has been suggested as mediating t-PA binding to hepatoma cells. ${ }^{46}$ However, this could not be confirmed in another study ${ }^{47}$ and no additional inhibition of t-PA clearance with fucosyl-BSA was found in vivo. ${ }^{39}$ Some cell-associated molecules bind to the lysine binding site of t-PA (amphoterin, ${ }^{48}$ gangliosides, $\alpha$ enolase, ${ }^{49}$ and other proteins ${ }^{50}$ ). These molecules are thought to play a role in the colocalization of $\mathrm{t}$ PA and plasminogen and the formation of plasmin on the cell surface. Cell-associated proteins which do not bind t-PA in a lysine binding site or active site dependent way have also been found. ${ }^{51-53}$ Furthermore it has been shown that t-PA is able to bind in a finger and kringle 2 domain-dependent manner to heparin. ${ }^{54,55}$ Proteoglycans from vascular endothelial cells have been shown to bind t-PA. ${ }^{57}$ Cell-bound proteoglycans have been shown to increase the binding of some ligands to the cell and 
thereby the uptake by the LRP ${ }^{56}$ and the VLDL receptor. ${ }^{58}$ The contribution of the above-mentioned putative t-PA binding molecules to the clearance of t-PA is, however, still unknown.

The functioning of both the human mannose receptor and the LRP can be studied at the same time in cultured human monocyte derived macrophages. Inhibitors of the mannose receptor and the LRP inhibit t-PA degradation by macrophages each by approximately $50 \%$ and in combination by $95 \%$. Furthermore, t-PA binding to these cells is partially inhibited by a lysine analog but this analog does not affect t-PA degradation. ${ }^{59}$ We have shown that the effects of inhibitors studied in this human in vitro model are representative of the effects of inhibitors on the t-PA clearance in vivo in the rat. ${ }^{60,61}$

\section{Tissue distribution of the mannose receptor and LRP}

One of the above-mentioned monoclonal antibodies against the human mannose receptor was used in flow cytometry and immunohistochemistry to determine the cellular expression and the tissue distribution of the mannose receptor. ${ }^{33,60,62,63}$ We have shown that isolated human monocytes and lymphocytes do not express the mannose receptor. Cultured human monocytes start to express the mannose receptor after a few days in culture. Expression of the mannose receptor as detected by this antibody is upregulated by dexamethasone and downregulated by lipopolysaccharide. ${ }^{62}$

By use of immunohistochemistry we have shown that the mannose receptor is expressed by only a few human cell types. In all vital organs resident tissue macrophages expressed the mannose receptor (including the alveolar macrophages, ${ }^{63}$ Kupffer cells, ${ }^{60}$ Hofbauer cells, ${ }^{33}$ perivascular glial cells, and synovial lining cells ${ }^{63}$ ). Not all macrophages express the mannose receptor; the macrophages in the thymus medulla, ${ }^{62}$ in the B cell areas of lymph nodes ${ }^{62}$ and spleen, ${ }^{63}$ and the microglial cells in the brain ${ }^{63}$ were all mannose receptor-negative. In these studies the only non-mononuclear phagocytes expressing the mannose receptor in human tissue are liver sinusoidal endothelial cells, ${ }^{60}$ spleen sinusoidal endothelial cells ${ }^{63}$ and sperm cells. ${ }^{63}$ In these studies it was also shown that the monoclonal antibody is specific for the $175 \mathrm{Kd}$ mannose receptor; the antibody did not stain cells that express MBP like liver parenchymal cells ${ }^{64}$ and lymphocytes ${ }^{65}$ nor did it stain cells that express receptors with a configuration similar to that of the mannose receptor (DEC-205 ${ }^{66}$ and phospholipase A2 receptor ${ }^{67}$ ).

In contrast to the mannose receptor, LRP is expressed in many more cell types such as neurons, astrocytes, epithelial cells, smooth muscle cells, fibroblasts, lipocytes, fibroblasts, chondrocytes, hepatocytes, syncytiotrophoblasts, Leydig cells, monocytes, macrophages, Kupffer cells, and Hofbauer cells. ${ }^{68}$ gp330 is not expressed in the liver but only in kidney, lung and intestine. ${ }^{69}$ The VLDL receptor is found in skeletal muscle, heart muscle and vascular endothelial cells. ${ }^{70}$

\section{The ligands and functions of the mannose receptor}

Alveolar macrophages are able to bind the lysosomal enzyme ß-glucuronidase in a mannan-inhibitable way. ${ }^{71,72}$ Non-parenchymal liver cells are found also to endocytose similarly glycosylated lysosomal enzymes in a mannan-inhibitable way. ${ }^{73,74}$ After the binding of the ligand to this mannan-inhibitable receptor, the ligand-receptor complex is internalised, the ligand dissociates from the receptor in the acidic environment of the endosome $(\mathrm{pH} \mathrm{5-6)}$ and the receptor is recycled to the membrane while the ligand is delivered to the lysosome. ${ }^{75-77}$ The $175 \mathrm{kDa}$ mannose receptor has been purified from extracts of macrophages, ${ }^{78}$ placenta ${ }^{79}$ and liver.$^{30}$ In 1990 the primary structure of the receptor was elucidated ${ }^{80,}$ and the characteristics of the individual mannose receptor domains were studied by using mutant receptors. ${ }^{81-84}$ 
An overview of the mannose receptor ligands is shown in Table 1 (see page 108). All mannose receptor ligands are also ligands for other receptors. Various (lysosomal) enzymes are cleared by the mannose receptor as well as the mannose-6-phosphate receptor or the galactose receptor. ${ }^{85}$ The contribution of each receptor to the clearance of endogenous lysosomal enzymes can be different from the clearance of administrated isolated enzymes. ${ }^{85}$ Some enzymes, for example renin, ${ }^{93}$ consists of different isoenzymes and only a subpopulation (subtype B of renin) of the isoenzymes contains a mannose receptor recognition site. Therefore it is difficult to predict what inhibition of the mannose receptor would do to the concentrations of endogenous ligands in vivo. Until now only one study has shown that inhibition of the mannose receptor in vivo results in increased endogenous t-PA plasma concentrations. ${ }^{61}$

In the liver the mannose receptor functions mainly as a clearance receptor of ligands in the circulation. Some lysosomal enzymes are not degraded after uptake, instead they continue to function in the endothelial cell lysosome. ${ }^{86.89}$ It has been shown that the mannose receptor-mediated endocytosis by liver endothelial cells is 3 to 7 times higher than by Kupffer cells. ${ }^{115}$ This is also reflected in the in vivo uptake of t-PA where the endothelial cells contain six times more t-PA per mg cell protein than the Kupffer cells. ${ }^{26}$ In contrast to healthy human cells, apoptotic human cells expose mannose and galactose residues on their surface. The mannose receptor is one of the receptors used in the liver by non-parenchymal cells to phagocytose apoptic cells. ${ }^{105,106}$ In contrast to endocytosis, mannose receptormediated phagocytosis is more rapidly mediated by the Kupffer cells than by liver endothelial cells. ${ }^{105}$

In addition to the clearance of glycoproteins, the mannose receptor functions to mediate the phagocytosis of various pathogens. ${ }^{98}$ Furthermore the mannose receptor is likely to be involved in antigen presentation, ${ }^{116}$ foreign body-type giant cell formation, ${ }^{117}$ the homing of lymphocytes to the spleen, ${ }^{118}$ retinal phagocytosis ${ }^{104}$ and sperm fertility. ${ }^{119}$

\section{$t$-PA binding sites of the mannose receptor}

Unlike the LRP ligands (see below) many mannose receptor ligands have been shown to inhibit each other's binding, though with different affinities. Studies with mutant t-PA and endo $\mathrm{H}$ treated t-PA have shown that the (tri-antennary) high mannose-type oligosaccharide present on kringle 1 of t-PA binds to the mannose receptor and mediates part of the t-PA clearance. ${ }^{29,120}$ We have shown recently that the binding of t-PA to the mannose receptor is much stronger (500 fold) than the binding of two other ligands containing a similar high mannose-type oligosaccharide: ribonuclease $B$ and ovalbumin. The complex-type oligosaccharides and the O-linked fucose in the growth factor domain of t-PA did not significantly contribute to this high affinity binding of t-PA. The affinity of the trypsin digest of t-PA was 500 fold lower than that of intact t-PA, whereas trypsin digests of ribonuclease $B$ and ovalbumin had a 23 fold lower affinity than intact ribonuclease $B$ and ovalbumin. This indicated that the high affinity of t-PA was not caused by a different type of oligosaccharide. We hypothesized that the conformation of the high mannose-type oligosaccharide is influenced by the protein part of t-PA in such a way that it has a higher affinity for the mannose receptor. Complex formation with PAl-1 or $\alpha_{2}$-antiplasmin did not affect the affinity of t-PA for the mannose receptor. ${ }^{31}$ 
The mannose receptor (Fig 1 ) is a type I transmembrane protein consisting of a $\mathrm{N}$-terminal cysteine rich domain, a fibronectin type II repeat, eight carbohydrate recognition domains (CRD), and a C-terminal transmembrane region and cytoplasmatic tail. ${ }^{88}$ Using truncated mutant receptors it has been found that CRD 4, 5 and 7 are essential for the high affinity ( $\mathrm{Ki}$ in the $\mathrm{nM}$ range) binding of mannan; mutant mannose receptors missing one or two of these domains have much lower affinities for mannan ( $K i$ in the $\mu \mathrm{M}$ to $\mathrm{mM}$ range). CRD 4 is essential for efficient endocytosis, and CRD 6 and/or CRD 7 is essential for the release of the ligand at $\mathrm{pH} 5-6$.

The affinity of monosaccharides for the receptor is low ( $\mathrm{mM}$ range) in the order D-mannose = L-fucose $>\mathrm{N}$-acetylglucosamine $\geq \mathrm{D}$-glucose $>\mathrm{D}$-galactose $>\mathrm{N}$-acetylgalactosamine. ${ }^{29,72,78}$ The affinity of polysaccharides for the receptor is much higher. Synthetic ligands like mannose ${ }_{48}$-albumin (48 molecules mannose per molecule albumin) and mannose ${ }_{104}$-polylysine have affinities in the $\mathrm{nM}$ range for the mannose receptor expressed on cells ${ }^{77,122}$ while synthetic ligands containing less mannose residues like mannose ${ }_{5}$-albumin ${ }^{122}$ and polylysines containing two to four mannose residues ${ }^{123}$ have affinities in the $\mu \mathrm{M}$ range. Isolated glycopeptides containing tri-antennary high mannose-type oligosaccharides have affinities in the $\mu \mathrm{M}$ range and glycopeptides containing di-antennary oligosaccharides are not detectably endocytosed by rat liver endothelial cells in vitro. ${ }^{124}$ Tri-antennary oligosaccharides with long antennae are able to inhibit antigen presentation by macrophages in the $\mathrm{nM}$ range while tri-antennary oligosaccharides with shorter antennae have affinities in the $\mu \mathrm{M}$ range. ${ }^{125}$

The above-mentioned differences in affinity of the mannose receptor-ligand interactions suggest that the number of, and spacing between, the terminal saccharides determine the number of carbohydrate recognition domains the ligand can bind to and thereby its affinity for the mannose receptor. Recently, lysine-based cluster mannosides have been synthesized with two (mannose $e_{2}-$ lysine $_{1}, M_{2} L_{1}$ ) to six (mannose $e_{6}$-lysine ${ }_{5}, \mathrm{M}_{6} \mathrm{~L}_{5}$ ) terminal $\alpha$-D-mannose residues that are connected to a polylysine backbone with flexible elongated spacers. We have shown that all mannosides are able to inhibit t-PA and ribonuclease $\mathrm{B}$ binding to the isolated mannose receptor. The affinity of this series of mannosides continuously increases from $20 \mu \mathrm{M}$ to $1 \mathrm{nM}$ per mannoside with mannose valency increasing from two to six. $^{126}$

We have tested the same mannosides for their affinity towards isolated rat liver endothelial cells and cultured human macrophages that both express the mannose receptor. The affinity of the mannosides towards the mannose receptor expressed on cells show no species or cell-type differences. The mannosides $\mathrm{M}_{5} \mathrm{~L}_{4}$ and $\mathrm{M}_{6} \mathrm{~L}_{5}$ inhibit t-PA binding and degradation in the $\mu \mathrm{M}$ and the $n M$ range, respectively. This difference in affinity is also found in vivo; $0.03 \mathrm{mg} / \mathrm{rat}$ or $0.3 \mathrm{mg} / \mathrm{rat} \mathrm{M}_{6} \mathrm{~L}_{5}$ inhibit t-PA clearance much stronger (respectively $50 \%$ and $60 \%$ ) than $0.3 \mathrm{mg} / \mathrm{rat} \mathrm{M}_{5} \mathrm{~L}_{4}(40 \%)$. ${ }^{60} \mathrm{~A}$ combination of $0.3 \mathrm{mg} / \mathrm{rat} \mathrm{M}_{6} \mathrm{~L}_{5}$ and $10 \mathrm{mg} / \mathrm{rat}$ RAP inhibit t-PA clearance by $90 \% .{ }^{40}$

In conclusion: t-PA binds with its tri-antennary high mannose-type oligosaccharide with high affinity to the mannose receptor. This binding is completely blocked by mannose and by poly-mannosides. The affinity of the inhibitors increases with increasing mannose valency. The high affinity of t-PA for the mannose receptor suggests that the high mannose-type oligosaccharide of t-PA interacts with more than one carbohydrate recognition domain of the mannose receptor. A simple model for the interaction between the mannose receptor and t-PA is shown in Fig 1. 
Fig 1

Schematic representation of the putative Interaction of t-PA with the mannose receptor.

Mannose receptor (MR) with the $\mathrm{N}$ terminal cysteine rich domain (C), fibronectin type II repeat $\left(F_{n}\right)$, eight carbohydrate recognition domains (1-8) with the mannose binding sites ( in 4 , 5 and 7), and a C-terminal transmembrane region and cytoplasmatic tail. t$P A$ with the finger domain (F), growth factor domain (G), kringle 1 (K1) containing a high mannose-type oligosaccharide with $2 \mathrm{~N}$-acetylglucosamine residues $(\mathrm{O})$ and at least 6 mannose residues $(\bullet)$, kringle 2 $(\mathrm{K} 2)$, and the protease domain $(\mathrm{P})$.

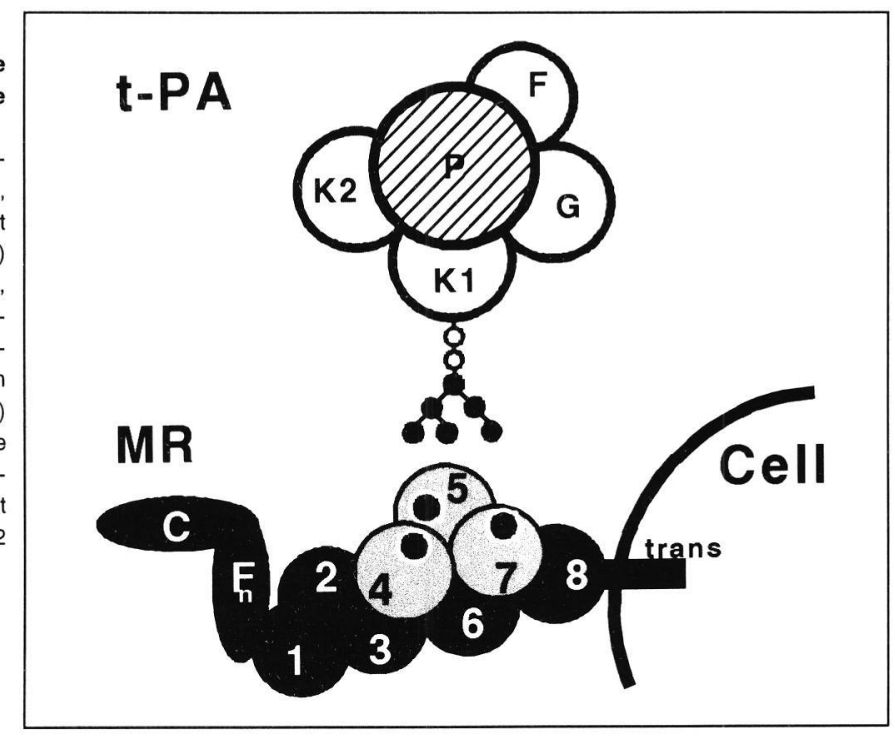

\section{The ligands and functions of the LDL receptor family}

The LRP is a member of the LDL receptor family, ${ }^{127}$ and is involved in the clearance of a lot of different ligands: proteinases, inhibitors and their complexes with proteinases, and the lipoproteins $L D L$ and apolipoprotein E (apo E) or lipoprotein lipase (LPL) enriched VLDL (apo E-VLDL, LDL-VLDL) (see Table 1 , for reviews see ${ }^{41,107,128-131}$ ). No other functions than uptake and degradation of its ligands have been described for the various members of the LDL-receptor family. LRP is a very large type 1 transmembrane receptor consisting of two subunits of $515 \mathrm{kDa}$ and $85 \mathrm{kDa}$, respectively. RAP is frequently used in inhibition studies to demonstrate involvement of the LRP, ${ }^{132}$ but it has later been show that RAP also inhibits ligand binding to gp330 and the VLDL receptor. ${ }^{41}$ gp330 is a receptor analogous to the LRP. It has a similar size and ligand spectrum as the LRP including the ligands t-PA-PAI-1, ${ }^{37}$ urokinase-PAI-1 (UPA-PAI-1) ${ }^{133}$ and thrombin-PAI-1. ${ }^{110}$ As gp330 is not expressed in the liver or vascular endothelial cells ${ }^{69}$ it is not likely to be involved in t-PA clearance. The VLDL receptor is a $130 \mathrm{kDa}$ protein which does not recognise activated (fast form) $\alpha_{2}$-macroglobulin $\left(\alpha_{2} M^{*}\right)$ but does mediate internalisation of pro-uPA, UPA-PAI-1, LPL, ${ }^{134}$ and apo E-VLDL. ${ }^{58}$ In contrast to the LRP ${ }^{133}$ the VLDL receptor is expressed by vascular endothelial cells. ${ }^{70}$ t-PA-PAI-1 binds to the VLDL-receptor, ${ }^{42}$ and it has been shown that vascular endothelial cells degrade t-PA probably after complex formation with PAI-1, ${ }^{135,136}$ and that degradation by these cells could be inhibited by RAP. ${ }^{136}$ Thus the VLDL receptor on endothelial cells might contribute to the plasma clearance of t-PA.

\section{t-PA binding sites of LRP}

Some controversy exists whether the LRP is able to mediate binding of free t-PA. t-PA does not bind to the LRP in a ligand blot, while t-PA-PAl-1 does. ${ }^{36,137}$ On the other hand t-PA can bind to the isolated immobilised LRP ${ }^{109}$ and inactivated t-PA, unable to interact with PAI-1, is still degraded by the LRP expressed on hepatoma cells ${ }^{36,138}$ and human macrophages. ${ }^{59}$ It cannot be excluded that t-PA binds in an active site-independent manner to a third molecule that is lost during ligand blotting and that $t-P A$, after binding to this molecule, is taken up via the LRP expressed on cells. 
Table 1. An overview of the ligands of the mannose receptor and of LRP.

\section{Mannose receptor ligands}

enzymes

tissue-type plasminogen activator (t-PA) (see text)

B-glucuronidase ${ }^{71,72}$

$\mathrm{N}$-acetyl-B-glucuronidase ${ }^{73}$

$\alpha$-mannosidase ${ }^{73}$

B-galactosidase ${ }^{74,85}$

glycosylasparaginase ${ }^{86}$

hyaluronidase ${ }^{87}$

arylsulfatase $A^{85}$

salivary amylase ${ }^{88}$

myeloperoxidase ${ }^{89}$

dopamine-ß-hydroxylase ${ }^{90}$

acetylcholine esterase ${ }^{91}$

tissue kallikrein ${ }^{92}$

renin (subtype B) ${ }^{93.94}$

\section{glycoproteins}

B-cell modified $\alpha_{2}$-macroglobulin (slow form) ${ }^{95}$

C-terminal propeptide type I procollagen ${ }^{96}$

uteroferrin ${ }^{97}$

\section{organisms}

Kliebsella Pneumoniae ${ }^{98}$

Escherichia Coli ${ }^{98}$

Mycobacterium Avium $^{98}$

Mycobacterium Tuberculosis ${ }^{98,99}$

Pseudomonas Aeroginosa ${ }^{98}$

Aspergillus Fumigatus ${ }^{98}$

Candida Albicans ${ }^{98}$

Candida Kruse ${ }^{98}$

Cryptococcus Neoformans ${ }^{98}$

Saccharomyces Cerevisae ${ }^{100}$

Pneumocytis Carinii ${ }^{98}$

Trypanosoma Cruzi amastigotes ${ }^{10}$

Leishmania Donovani ${ }^{98}$

other ligands

ricin $^{102}$

bee venom phospholipase $A^{103}$

photoreceptor outer segments ${ }^{104}$

apoptotic lymphocytes/apoptotic bodies ${ }^{105,106}$

\section{LRP ligands}

\section{enzymes}

tissue-type plasminogen activator (t-PA) (see text)

urokinase (U-PA) ${ }^{41,107}$

pro-urokinase (pro-u-PA) ${ }^{108,109}$

lipoprotein lipase (LPL) ${ }^{41.107}$

kallikrein ${ }^{108}$

\section{inhibitors}

plasminogen activator inhibitor-1 (PAI-1) ${ }^{110}$

tissue factor pathway inhibitor (TFPI) ${ }^{41}$

\section{enzyme-inhibitor complexes}

t-PA-PAl- ${ }^{41,107}$ u-PA-PAl- $1^{41,107}$ and thrombin-PAl- $1^{111}$

$\alpha_{2}$-macroglobulin-proteinase (fast form) $\alpha_{2} \mathrm{M}, \alpha_{2} \mathrm{M}^{\star 41,107}$ pregnancy zone protein-proteinase ${ }^{41,107}$

elastase- $\alpha_{1}$-antitrypsin ${ }^{41}$

thrombin-antithrombin III ${ }^{112}$

thrombin-heparin cofactor ${ }^{11}{ }^{112}$

u-PA-protease nexin $1^{41}$

\section{lipoproteins}

low density lipoprotein (LDL) ${ }^{113}$

apolipoprotein $E$ enriched B-very low density lipoprotein (apo E-B-VLDL) ${ }^{41,107}$

LPL enriched VLDL (LPL-VLDL) ${ }^{41,107}$

LPL enriched B-VLDL (LPL-B-VLDL) ${ }^{41,107}$

matrix proteins

thrombospondin $1^{41}$ and $2^{114}$

\section{toxins and viruses}

Pseudomonas exotoxin $A^{41,107}$

minor-group human rhinovirus ${ }^{41.107}$

other ligands

apolipoprotein E (apo E) ${ }^{41,107}$

lactoferrin ${ }^{41,107}$

receptor associated protein (RAP) ${ }^{41,107}$ 
The LRP binds to its ligands with different sites on the receptor. Although RAP seems to inhibit binding of all ligands, not every ligand competes with all other ligands for binding to the LRP. LPL-VLDL, apo EVLDL, lactoferrin nor $\alpha_{2} \mathrm{M}^{*}$ are able to inhibit t-PA-PAI-1 degradation by human fibroblasts. ${ }^{37} \mathrm{t}-\mathrm{PA}$ and pro-u-PA have different binding sites since the isolated immobilised LRP binds t-PA and this binding is not inhibited by pro-u-PA. ${ }^{109}$ Using a mutant LRP (amino acids 836-2501) it was found that the binding sites of t-PA, t-PA-PAI-1 and uPA-PAl-1 are located on region II of LRP. ${ }^{137}$ This mutant receptor is not able to interact with $\alpha_{2} \mathrm{M}^{*}$, while in another study an isolated LRP fragment (amino acids 776-1399) has been found to bind the light chain of $\alpha_{2} \mathrm{M}$ (binding domain similar to $\alpha_{2} \mathrm{M}^{*}$ ) and u-PA-PAl-1. ${ }^{139}$ uPA-PAl-1 binding to the isolated LRP is inhibited by uPA-PAI-1, pro-u-PA, UPA, t-PA-PAI-1 and active or latent PAl1 with high affinity, while t-PA inhibits UPA-PAI- 1 binding with a very low affinity. ${ }^{108,110}$ This indicates that u-PA-PAl-1 has overlapping binding sites with pro-u-PA, PAI-1 and t-PA-PAl-1 but not with t-PA.

The t-PA growth factor and finger domain appear to mediate binding of t-PA and t-PA-PAl-1 to the LRP. Inhibition studies with isolated t-PA domains show that a fragment containing the finger and growth factor domain of t-PA is able, and mutant t-PA lacking the finger and growth factor domain is unable, to inhibit t-PA and t-PA-PAl-1 degradation by Novikoff hepatoma cells. ${ }^{47,141}$ Mutant t-PA lacking the finger and growth factor domain has also been shown to be unable to inhibit t-PA binding to smooth muscle cells. ${ }^{135}$ The clearance of t-PA mutants is delayed when they have deletions in the finger or growth factor domain indicating the involvement of these domains in the binding of t-PA to clearance receptors in vivo. ${ }^{142} \mathrm{~A}$ t-PA mutant consisting only of the kringle 2 and protease domain ("reteplase") has a low affinity for isolated parenchymal cells and RAP did not significantly affect the plasma clearance of reteplase. ${ }^{140}$ Compared to t-PA, reteplase is also less efficiently degraded by vascular endothelial cells, the degradation was RAP inhibitable. ${ }^{136}$ Though only a small amount of reteplase is cleared by the liver, it is still taken up by the liver in a RAP inhibitable way, which indicates that the liver-mediated clearance of reteplase and/or complexes of reteplase with PAI- 1 is mediated by the LRP. ${ }^{140}$

It appears that the LRP binding sites of t-PA and t-PA-PAI-1 are only partially overlapping. RAP binds in a $\mathrm{Ca}^{2+}$-dependent and a $\mathrm{Ca}^{2+}$-independent way to the various ligand binding sites of LRP. ${ }^{132} \mathrm{t}$-PA binding by hepatic cells is $\mathrm{Ca}^{2+}$-dependent ${ }^{143,144}$, while the binding of t-PA-PAl- 1 is not. ${ }^{145}$ it has been shown that Fab fragments against $\mathrm{Ca}^{2+}$-dependent binding sites of LRP are able to inhibit u-PA-PAl-1 and pro-u-PA binding to the isolated LRP, while they are not able to inhibit t-PA-PAl-1 binding. ${ }^{146}$ Binding studies with mutants of t-PA revealed that t-PA lacking the growth factor domain binds in a $\mathrm{Ca}^{2+}$ independent way, while t-PA lacking the finger domain binds in a $\mathrm{Ca}^{2+}$ dependent way to rat liver parenchymal cells. ${ }^{144}$

In the above-mentioned studies the affinities of t-PA and t-PA-PAI-1 for LRP expressed on intact cells were in the range of 1-30 nM. Compared to u-PA or PAI-1, u-PA-PAl-1 has a higher affinity for the LRP ${ }^{110}$; similarly, compared to t-PA, t-PA-PAI-1 has a higher affinity for human hepatocytes ${ }^{147}$ and is degraded faster than t-PA by rat novikoff hepatoma cells. ${ }^{141}$ The clearance of t-PA-PAI-1 is twice as fast as the clearance of free t-PA and six times faster than the clearance of free PAI-1 in an isolated perfused rat liver. ${ }^{148}$ However it also has been found that $\mathrm{t}$-PA is cleared faster in healthy human volunteers with low levels of PAI-1 activity than in volunteers with high PAl-1 activity. ${ }^{149}$ Thus it appears that active t-PA is cleared faster than t-PA-PAI-1 in man. A similar conclusion was reached by Chandler et al. ${ }^{150}$ 
In conclusion: the LRP binding site of t-PA not complexed to PAI-1 is partially overlapping with the t-PAPAI-1 binding site. t-PA and t-PA-PAl-1 probably bind with the finger and/or growth factor domain to the LRP. PAI-1 increases the affinity of t-PA for the LRP probably by binding of the PAI-1 moiety to a PAI-1 binding site on the LRP. The LRP binding sites of t-PA and pro-u-PA are different. The binding sites of tPA-PAI-1 and UPA-PAI-1 are partially overlapping probably by the PAl-1 binding site, and the binding sites of pro-uPA and UPA-PAl-are partially overlapping probably by the u-PA binding site. PAl-1 also increases the affinity of u-PA for the LRP. All these binding sites are likely to be localized on the second cluster of the complement-type cysteine-rich repeat (amino acids 836-1399) of LRP.

\section{Regulation of the mannose receptor and LRP}

Upon maturation from monocytes (which do not express the mannose receptor) to macrophages the mannose receptor is expressed. ${ }^{59,62,151}$ Interleukin-4, ${ }^{152}$ interleukin-13, ${ }^{153}$ prostaglandin E2 ${ }^{154}$ and dexamethasone ${ }^{59,62,155,156}$ upregulate the mannose receptor expression on macrophages. Bacillus Calmette Guerin, ${ }^{158}$ lipopolysaccharide, ${ }^{59,62,116,159}$ oxidant, $\quad{ }^{160}$ proteolysis, $\quad{ }^{16} \mathrm{Y}$-interferon, $\quad{ }^{162}$ and a combination of interleukin-1 and tumour necrosis factor- $\alpha{ }^{116}$ all downregulate mannose receptormediated ligand uptake by macrophages. Only for $y$-interferon it has been shown that it downregulates mannose receptor biosynthesis. The downregulation by $\mathrm{Y}$-interferon can be counteracted on the mRNA level by prostaglandin E2 ${ }^{162}$ and dexamethasone. ${ }^{163}$ These studies were all performed on macrophages in vitro. Recently, we have shown that up- or downregulation of the mannose receptor also occurs in vivo in man. ${ }^{63}$ Upregulated mannose receptor expression is found in a foreign body reaction in the synovium, and downregulated mannose receptor expression is found on macrophages in human tissue affected by diseases such as cancer, tuberculosis and rheumatoid arthritis. ${ }^{63}$

Little is known about the regulation of mannose receptor expression by liver endothelial cells but it might be regulated differently from macrophages. It has been shown that tumour necrosis factor- $\alpha$ and interleukin- $1 \beta$ do not downregulate but instead upregulate the uptake of mannan in liver endothelial cells in vitro. This was not caused by upregulation of receptor expression but by upregulation of the endocytotic efficiency. ${ }^{164}$ The mannose receptor expression on liver endothelial cells increases shortly after birth and decreases during ageing in the rat. ${ }^{165}$ Furthermore glucose has been shown to downregulate mannose receptor expression on macrophages, ${ }^{166}$ and high plasma glucose levels decrease the clearance of mannose receptor ligands in diabetic rats. ${ }^{90,167,168}$

Upon differentiation from monocytes (which do express the LRP) to macrophages the LRP is upregulated. ${ }^{59}$ Activation by Bacillus Carmette Guerin and lipopolysaccharide downregulates the LRP expression on macrophages ${ }^{59.158}$ while dexamethasone has no effect. ${ }^{59}$ Dexamethasone upregulates the LRP on hepatoma cells. ${ }^{169}$ Furthermore it has been shown that insulin upregulates the LRP on adipocytes ${ }^{170}$ and on hepatoma cells. ${ }^{171}$

\section{Conditions that may influence systemic t-PA clearance in vivo.}

The expression of the mannose receptor and LRP on cells in tissues ${ }^{63,68}$ may play an important role in regulating the local concentrations of t-PA, but this remains to be shown. The liver plays a major role in the clearance of t-PA from the blood. ${ }^{19,21}$ The clearance by the liver is very efficient and not easily saturated. Exercise reduces the liver blood flow and increases thereby endogenous t-PA concentrations, while increase of the liver blood flow has no strong effect on t-PA concentrations. ${ }^{22,23,150}$ The importance of efficient clearance of t-PA by the liver in maintaining homeostasis becomes evident in chronic liver disease where severe bleeding complications often are found. In this situation the concentration of t-PA 
increases strongly while the PAI-1 concentration increases less strongly, ${ }^{173}$ or even decreases. ${ }^{174}$

Some conditions have been shown to affect t-PA concentrations and have the same influence on the concentrations of other ligands of the mannose receptor. Increased levels of t-PA antigen and mannose receptor ligands are found under the following circumstances: liver disease (t-PA, ${ }^{173,174} \mathrm{~N}$-acetyl- 3 glucosaminidase, $\beta$-glucuronidase ${ }^{175}$ ), gender and age (male $>$ female and increase with age, t-PA, ${ }^{176}$ B-glucuronidase, $\mathrm{N}$-acetyl-B-glucosaminidase ${ }^{177,178}$ ), pregnancy (t-PA, ${ }^{179,180} \quad B$-glucuronidase and $\mathrm{N}$ acetyl- $B$-glucosaminidase ${ }^{181,182}$ ), high body mass index (t-PA, ${ }^{183} \mathrm{~N}$-acetyl-B-glucosaminidase ${ }^{178}$ ), and obesity (t-PA, ${ }^{180} \mathrm{~N}$-acetyl-B-glucosaminidase and $\alpha$-D-mannosidase ${ }^{184}$ ). One study demonstrated that hyperlipidaemic rats have a decreased clearance of t-PA. ${ }^{185}$ Whether in all above-mentioned conditions t-PA clearance is really affected remains to be shown.

A more complicated condition where both mannose receptor and LRP mediated t-PA clearance could be influenced is diabetes. Diabetic rats have a decreased mannose receptor mediated clearance and increased plasma concentrations of the mannose receptor ligand dopamine B-hydroxylase. ${ }^{90,167,168}$ Insulin has been shown to upregulate LRP expression on adipocytes and hepatoma cells. ${ }^{170,171}$ In diabetes type I patients increased concentrations of $\mathrm{N}$-acetyl-B-glucosaminidase and Bglucuronidase ${ }^{186-188}$ have been found. Diabetes type 1 patients have decreased ${ }^{189,190}$ or increased ${ }^{191} \mathrm{t}$ PA antigen concentrations. t-PA antigen is increased in diabetes type I patients before insulin treatment and decreased to below control values after insulin treatment. ${ }^{192}$ In diabetes type II patients t-PA antigen positively correlates with insulin resistance. ${ }^{193,194}$ In these patients both t-PA antigen ${ }^{194,195}$ and N-acetyl-Bglucuronidase ${ }^{186}$ are increased and decreased concentrations are observed with glycemic control. ${ }^{186,195}$ However, it remains to be determined whether mannose receptor and/or LRP-mediated t-PA clearance is influenced in diabetic type I and type II patients before and after insulin treatment.

\section{Possible use of clearance inhibitors in thrombolytic and antithrombotic therapy}

In thrombolytic therapy high doses of recombinant t-PA are used since it is cleared so fast from the circulation. Mutants of t-PA that have a lower affinity for the clearance receptors would require a lower dose for equal efficiency. Different mutants have been synthesized and tested for their efficiency compared to recombinant t-PA. Few mutants having a lower clearance rate retained the fibrin specificity and plasminogen activating capacity. These are currently being tested for their efficacy in thrombolytic therapy. ${ }^{4,6,142,196}$ Beside mutants of t-PA, inhibitors of clearance may be used in combination with t-PA to diminish the dosage of t-PA necessary for thrombolytic therapy.

An additional effect of reducing the clearance of the plasminogen activator used in thrombolytic therapy would be to diminish the side effect of bleeding complications. High concentrations of t-PA can induce systemic plasminogenolysis and increased bleeding complications. ${ }^{197} \mathrm{t}-\mathrm{PA}$ is a high clearance drug which means that the clearance is largely dependent on the liver blood flow. ${ }^{172}$ Myocardial infarct patients can have a decreased liver blood flow and thereby they may be more susceptible to overdosage and thus to bleeding complications. 22,172 Mutants of t-PA have a lower clearance because they bind with a lower affinity (or not at all) to the liver receptors. Clearance inhibitors reduce t-PA clearance by competing with t-PA for liver receptors. The clearance of low clearance drugs is less influenced by the liver blood flow. Thus use of low clearance t-PA mutants or coadministration of t-PA clearance inhibitors with a lower dose of t-PA may diminish the differences in clearance and thus t-PA plasma concentrations between patients with a high and low liver blood flow and may reduce the risk of t-PA overdosing in myocardial infarction patients. 
An additional potential use of clearance inhibitors in therapy would be the increase of endogenous t-PA concentrations. Since a low increase in the t-PA concentration present during clot formation already results in decreased thrombus formation, ${ }^{16}$ such inhibitors may be used without exogenous t-PA in the prevention of thrombosis. A drug that may exert its antithrombotic effect by inhibition of t-PA clearance is dextran. Dextran is used as a plasma volume expander, as a blood substitute and as a prophylactic agent against deep venous thrombosis in surgery. ${ }^{198,199}$ Dextran increases t-PA antigen concentrations and even more strongly increases the t-PA activity in patients. ${ }^{200}$ As dextran is a glucose-polymer it is a potential inhibitor of mannose receptor-mediated t-PA clearance. We showed ${ }^{63}$ that dextran inhibits the binding of $t-P A$ to the isolated mannose receptor. At therapeutic concentrations dextran partially $(60 \%)$ inhibits mannose receptor-mediated but not the LRP-mediated t-PA degradation by human macrophages. Furthermore we showed in the same report that an infusion of dextran increases endogenous t-PA concentrations in plasma by partially $(33 \%)$ inhibiting t-PA clearance in rats. Thus the inhibition of t-PA clearance by dextran resulted in increased endogenous t-PA concentrations which may explain the antithrombotic effect of dextran in man. Since patients can be treated for days with dextran and dextran does not appear to have toxic side effects (beside immediate allergic reactions, or bleeding complications at a very high dosage, ${ }^{198,199}$ ) the inhibition of mannose receptor-mediated t-PA clearance may be a safe prophylactic therapy against thrombosis.

A recently developed cluster mannoside is able to inhibit t-PA clearance by $60 \%$ apparently without toxic effects in rats. ${ }^{40}$ This compound could be more efficient than dextran and may have a stronger effect on endogenous t-PA concentrations and thus could be a better agent than dextran for preventing deep venous thrombosis in man. Further studies are required to provide evidence for this intriguing possibility of a new type of antithrombotic therapy.

\section{Conclusion}

The plasma clearance of t-PA is mainly mediated by the mannose receptor and the LRP expressed in the liver. The high mannose-type oligosaccharide of $t-P A$ binds to the mannose receptor; the growth factor and finger domain are involved in the binding of t-PA to the LRP. The expression of these receptors in the liver possibly influences the clearance of t-PA under (patho)physiological conditions and thereby the plasma concentration of endogenous t-PA. Inhibitors of the (mannose receptor-mediated) clearance are of potential interest in thrombolytic and antithrombotic therapy.

\section{ACKNOWLEDGEMENT}

This study wers financially supported by the Netherlands Heart Foundation grant no. 90.294.

\section{REFERENCES}

1 Rijken D C, Wijngaards G, Welbergen J. Relationship between uterine plasminogen activator and the activators in blood and vascular wall. Thromb Res 1980; 18: 815-830.

2 Pennica D, Holmes W E, Kohr W J, Harkins R N, Vehar G $A$, Ward C A, Bennett W F, Yelverton E, Seeburg P $H$, Heyneker H L, Goeddel D V, Collen D. Cloning and expression of human tissue-type plasminogen activator cDNA in E.coli. Nature 1983; 301: 214-221

3 Gillis J C, Wagstaff A J, Goa K L. Alteplase. A reappraisal of its pharmacological properties and therapeutic use in acute myocardial infarction. Drugs 1995; 50: 102-136.

4 Collen D. Fibrin-selective thrombolytic therapy for acute 9 myocardial infarction. Circulation 1996; 93: 857-865.

5 Califf R M, White H D, van der Werf F, Sadowski Z,
Armstrong $P$ W, Vahanian A, Simoons M L, Simes R J, Lee $\mathrm{K} \mathrm{L}$, Topol E J. One-Year results from the global utilization of streptokinase and TPA for occluded coronary arteries (GUSTO-I trial). Circulation 1996; 94: 1233-1238.

6 Bachmann F. Fibrinolytic agents. Fibrinolysis 1995; 9, Suppl 1: 9-15.

7 Rijken D C. Plasminogen activators and plasminogen activator inhibitors: biochemical aspects. Baillière's Clinical Haematology 1995; 8: 291-312.

8 Emeis $\mathrm{J}$ J. The control of TPA and PAl-1 secretion from the vessel wall. Vasc Med Rev 1995; 6: 153-166.

Kluft C. Constitutive synthesis of tissue-type plasminogen activator (t-PA) and plasminogen activator inhibitor type I (PAI-1): Conditions and therapeutic targets. Fibrinolysis 
1994; 8, Suppl 2: 1-7

10 Juhan-Vague I, Alessi M C, Declerck P J. Pathophysiology of fibrinolysis. Baillière's Clinical Hematology 1995; 8: 329343.

11 Binder B R Physiology and pathophysiology of the fibrinolytic system. Fibrinolysis 1995; 9, Suppl 1: 3-8.

12 Schrauwen $Y$, de Vries R E M, Kooistra T, Emeis $\mathrm{J} J$. Acute release of tissue-type plasminogen activator (t-PA) from the endothelium; regulatory mechanisms and therapeutic target. Fibrinolysis 1994; 8, Suppl 2: 8-12.

13 Giles A R, Nesheim, M E, Herring S W, Hoogendoom H, Stump D C, Heldebrandt C M. The fibrinolytic potential of the normal primate following the generation of thrombin in vivo. Thromb Haemostas 1990; 63: 476-481.

14 Brommer E J P. The level of extrinsic plasminogen activator (t-PA) during clotting as a determinant of the rate of fibrinolysis; inefficiency of activators added afterwards. Thromb Res 1984; 34: 109-115.

15 Zamarron C, Lijnen H R, Collen D. Influence of exogenous and endogenous tissue-type plasminogen activator on the lysability of clots in a plasma milieu in vitro. Thromb Res $1984 ; 35: 335-345$.

16 Emeis $\mathrm{J} \mathrm{J}$, Bekkers M. Low-dose infusion of tissue-type plasminogen activator (t-PA) prevents arterial thrombosis in a rat thrombosis model: IPA as an antithrombotic agent. Fibrinolysis 1996; 10, Suppl 3: 128. (abstract)

17 Charlton P A, Faint R W, Bent F, Bryans J, ChicarelliRobinson I, Mackie I, Machin S, Bevan P. Evaluation of a low molecular weight modulator of human plasminogen activator inhibitor-1 activity. Thromb Haemostas 1996; 75 : 808-815.

18 Kooistra T, Schrauwen Y, Arts J, Emeis J J. Regulation of endothelial cell t-PA synthesis and release. Int $\mathrm{J}$ Hematol 1994; 59: 233-255.

19 Nilsson $\mathrm{T}$, Wallén $\mathrm{P}$, Mellbring $\mathrm{G}$. In vivo metabolism of human tissue-type plasminogen activator. Scand $J$ Haematol 1984; 33: 49-53.

20 Verstraete $\mathrm{M}$, Bounameaux $\mathrm{H}$, de Cock $\mathrm{F}$, van de Werf $\mathrm{F}$, Collen D. Pharmacokinetics and systemic fibrinogenolytic effects of recombinant human tissue-type plasminogen activator (rt-PA) in humans. J Pharmacol Exp Ther 1985; 235: 506-511.

21 Brommer A J P, Derkx F H M, Schalekamp M A D H, Dooijewaard G. Renal and hepatic handling of endogenous tissue-type plasminogen activator (t-PA) and its inhibitor in man. Thromb Haemostas 1988; 59: 404-411.

22 de Boer A, Kluft C, Kroon J M, Kasper F J, Schoemaker H C, Pruis J, Breimer D D, Soons P A, Emeis J J, Cohen A F. Liver blood flow as a major determinant of the clearance of recombinant human tissue-type plasminogen activator. Thromb Haemostas 1992; 67: 83-87.

23 de Boer A, Kluft C, Dooijewaard G, Kasper F J, Kroon J M, Breimer D D, Stiekema J C, Cohen A F. Influence of heparin and a low molecular weight heparinoid on specific endogenous and exogenous fibrinolytic factors during rest and exercise. Thromb Haemostas 1992; 68: 550-555.

24 Einarsson $M$, Smedsrød B, Pertoft $H$. Endocytosis of tissue plasminogen activator (TPA) by rat liver cells. Thromb Haemostas 1985; 54: P1603. (abstract)

25 Hotchkiss A, Refino C J, Leonard C K, O'Connor J V, Crowley C, McCabe J, Tate K, Nakamura G, Powers D, Levinson A, Mohler M, Spellman M W. The influence of carbohydrate structure on the clearance of recombinant tissue-type plasminogen activator. Thromb Haemostas 1988; 60: 255-261.

26 Kuiper J, Otter M, Rijken D C, van Berkel Th J C. Characterization of the interaction in vivo of tissue-type plasminogen activator with liver cells. J Biol Chem 1988;
266: 13931-13935.

27 Lucore C L, Fry E T, Nachowiak D A, Sobel B E. Biochemical determinants of clearance of tissue-type plasminogen activator from the circulation. Circulation 1988; 77: 906-914.

28 Smedsrød B, Einarsson M, Pertoft $\mathrm{H}$. Tissue plasminogen activator is endocytosed by mannose and galactose receptors of rat liver cells. Thromb Haemostas 1988; 59 : 480-484.

29 Otter M, Barrett-Bergshoeff M M, Rijken D C. Binding of tissue-type plasminogen activator by the mannose receptor. J Biol Chem 1991; 266: 13931-13935.

30 Otter M, Zockova P, Kuiper J, van Berkel Th J C, BarrettBergshoeff M M, Rijken D C. Isolation and characterization of the mannose receptor from human liver potentially involved in the plasma clearance of tissue-type plasminogen activator. Hepatology 1992; 16: 54-59.

31 Noorman F, Barrett-Bergshoeff M M, Rijken D C. Role of carbohydrate in the binding of tissue-type plasminogen activator to the human mannose receptor. (submitted). Chapter 1 of this thesis.

32 Otter M, Kuiper J, Rijken D C, van Berkel Th J C. Characterization of the interaction both in vitro and in vivo of tissue-type plasminogen activator (t-PA) with rat liver cells. Effect of monoclonal antibodies to t-PA. Biochem $\mathrm{J}$ 1992; 284: 545-550.

33 Barrett-Bergshoeff M M, Noorman F, Bos R, Rijken D C. Monoclonal antibodies against the human mannose receptor that inhibit the binding of tissue-type plasminogen activator. Thromb Haemostas 1997;77:718-724. Chapter 3 of this thesis.

34 Bu G, Morton P A, Schwartz A L. Identification and partial characterization by chemical cross-linking of a binding protein for tissue-type plasminogen activator ( $t-P A)$ on rat hepatoma cells. A plasminogen activator inhibitor type 1independent t-PA receptor. J Biol Chem 1992; 267: 1559515602.

35 Bu G, Williams S, Strickland D K, Schwartz A L. Low density lipoprotein-related protein/ $\alpha_{2}$-macroglobulin receptor is an hepatic receptor for tissue-type plasminogen activator. Proc Nat Acad Sci USA 1992; 89: 7427-7431.

36 Orth K, Madison E L, Gething M J, Sambrook J F, Herz J. Complexes of tissue-type plasminogen activator and its serpin inhibitor plasminogen-activator inhibitor type 1 are intemalized by means of the low density lipoprotein receptor-related protein/ $\alpha_{2}$-macroglobulin receptor. Proc Nat Acad Sci USA 1992; 89: 7422-7426.

37 Willnow T E, Goldstein J L, Orth K, Brown M S, Herz J. Low densitiy lipoprotein receptor-related protein and gp330 bind similar ligands, including plasminogen activatorinhibitor complexes and lactoferrin, an inhibitor of chylomicron remnant clearance. J Biol Chem 1992; 267: 26172-26180.

38 Warshawsky I, Bu G, Schwartz A L. 39-kD protein inhibits tissue-type plasminogen activator clearance in vivo. J Clin Invest 1993; 92: 937-944.

39 Narita M, Bu G, Herz J, Schwartz A L. Two receptor systems are involved in the plasma clearance of tissuetype plasminogen activator ( $t-P A)$ in vivo. J Clin Invest 1995; 96: 1164-1168.

40 Biessen $E A L$, van Teijlingen $M$, Vietsch $H$, BarrettBergshoeff M M, Bijsterbosch M K, Rijken D C, van Berkel Th J C, Kuiper J. Antagonists of the mannose receptor and the LDL-receptor-related protein dramatically delay the clearance of tissue-type plasminogen activator. Circulation 1997; 95: 46-52.

41 Strickland D K, Kounnas M Z, Argraves W S. LDLreceptor-related protein: a multiligand receptor for 
lipoprotein and proteinase catabolism. FASEB J 1995; 9: 890-898.

42 Heegaard C W, Kasza A, Patersen $\mathrm{H} \mathrm{H}$, Simonsen A C $W$, Oka $K$, Chan $L$, Andreasen $P$ A. Binding and endocytosis of plasminogen activator serpin complexes by very low density lipoprotein receptor. Fibrinolysis 1996; 10, Suppl 3: 12 (abstract)

43 Kubak B M, Potempa L A, Anderson B, Mahklouf S, Venegas M, Gewurz H, Gewurz A T. Evidence that serum amyloid $\mathrm{P}$ component binds to mannose-terminated sequences of polysaccharides and glycoproteins. Mol Immunol 1988; 25: 851-858.

44 Childs R A, Feizi T, Yuen C T, Drickamer K, Quesenberry M S. Differential recognition of core and terminal portions of oligosaccharide ligands by carbohydrate-recognition domains of two mannose-binding proteins. J Biol Chem 1990; 265: 20770-20777.

45 Taylor M E, Summerfield J A. Human serum contains a lectin which inhibits hepatic uptake of glycoproteins. FEBS Lett 1984; 173: 63-66.

46 Hajjar K A, Reynolds C M. $\alpha$-Fucose-mediated binding and degradation of tissue-type plasminogen activator by HepG2 cells. J Clin Invest 1994; 93: 703-710.

47 Camani $\mathrm{C}$, Kruithof $\mathrm{E} \mathrm{K} \mathrm{O}$. The role of the finger and growth factor domains in the clearance of tissue-type plasminogen activator by hepatocytes. J Biol Chem 1995; 270: 26053-26056.

48 Parkkinen $\mathrm{J}$. Rauvala $\mathrm{H}$. Interactions of plasminogen and tissue plasminogen activator (t-PA) with amphoterin. Enhancement of t-PA-catalysed plasminogen activation by amphoterin. J Biol Chem 1991; 266: 16730-16735.

49 Felez J, Chanquia J, Fabregas P, Plow E F, Miles L A. Competition between plasminogen and tissue plasminogen activator for cellular binding sites. Blood 1993; 82: 24332441.

50 Fukao $H$, Hagiya $Y$, Nonaka $T$, Okada $K$, Matsuo $O$. Analysis of binding protein for tissue-type plasminogen activator in human endothelial cells. Biochem Biophys Res Comm 1992; 187:956-962.

51 Nguyen G, Self S J, Camani C, Kruithof E K O. Demonstration of a specific clearance receptor for tissuetype plasminogen activator on rat Novikoff hepatoma cells. J Biol Chem 1992; 267: 6249-6256.

52 Cheng $X F$, Back O, Nilsson T K, Nylander Lundqvist E, Pohl G, Wallén P. Binding of tissue-type plasminogen activator to human endothelial cells. Importance of the Bchain as a ligand. Biochem J 1992; 287: 407-413.

53 Haijar K A. Cellular receptors in the regulation of plasmin generation. Thromb Haemostas 1995; 74: 294-301.

54 Stein $\mathrm{P}$ L, van Zonneveld A J, Pannekoek H, Strickland S Structural domains of human tissue-type plasminogen activator that confer stimulation by heparin. $\mathrm{J}$ Biol Chem 1989; 264: 15441-15444.

55 Rijken D C, Jie A F H. Interaction of reteplase with heparin. A comparison between reteplase and alteplase. Blood Coag Fibr 1996; 7: 561-566.

56 Mahley R W, Ji Z S, Brecht W J, Miranda R D, He D. Role of heparan sulphate proteoglycans and the LDL receptorrelated protein in remnant lipoprotein metabolism. Ann N Y Acad Sci 1994; 737: 39-52.

57 Bohm T, Geiger M, Binder B R. Isolation and characterization of tissue-type plasminogen activatorbinding proteoglycans from human umbilical vein endothelial cells. Arterioscl Thromb Vasc Biol 1996; 16: 665-672.

58 Takahashi S, Suzuki J, Kohno M, Oida K, Tamai T, Miyabo $\mathrm{S}$, Yamamoto T, Nakai T. Enhancement of the binding of triglyceride-rich lipoproteins to the very low density lipoprotein receptor by apolipoprotein $E$ and lipoprotein lipase. J Biol Chem 1995; 270: 15747-15754.

59 Noorman F, Braat E A M, Rijken D C. Degradation of tissue-type plasminogen activator by human monocytederived macrophages is mediated by the mannose receptor and by the low density lipoprotein receptor-related protein. Blood 1995; 86: 3421-3427. Chapter 2 of this thesis.

60 Noorman F. Barrett-Bergshoeff M M, Biessen E A L, van de Bilt E, van Berkel Th J C, Rijken D C. Cluster mannosides can inhibit mannose receptor-mediated tissuetype plasminogen activator (t-PA) degradation by both rat and human cells. Hepatology 1997; in press. Chapter 7 of this thesis.

61 Noorman F, Barrett-Bergshoeff M M, Bekkers M, Emeis J $J$, Rijken D C. Inhibition of mannose receptor mediated clearance of tissue-type plasminogen activator ( $t$-PA) by dextran: a new explanation for its antithrombotic effect. Thromb Haemostas 1997; in press. Chapter 8 of this thesis.

62 Noorman F, Braat E A M, Barrett-Bergshoeff M M, Barbé E, van Leeuwen A, Lindeman J, Rijken D C. Monoclonal antibodies against the human mannose receptor as a specific marker in flow cytometry and immunohistochemistry for macrophages. J Leuk Biol 1997; 61: 6372. Chapter 4 of this thesis.

63 Noorman F, Barbé E, van Leeuwen A, Lindeman J, Rijken DC. Expression of the human mannose receptor under physiological and pathological conditions; An immunohistochemical study using monoclonal antibody 152. (submitted). Chapter 5 of this thesis.

64 Mori K, Kawasaki T, Yamashina I. Subcellular distribution of the mannan-binding protein and its endogenous inhibitors in rat liver. Arch Biochem Biophys 1988; 264 : 647-656.

65 Brock J, Schulze H A, Neels P, Fischer A, Bremer H, $W$ alzel $H$. Detection of mannose-binding proteins on mouse lymphocytes. Eur J Cell Biol 1991; 54: 90-94.

66 Jiang W, Swiggard WJ, Heufler C, Peng M, Mirza A, Steinman R M, Nussenzweig M C. The receptor DEC-205 expressed by dendritic cells and thymic epithelial cells is involved in antigen processing. Nature 1995; 375: 151-154.

67 Ishizaki J, Hanasaki K, Higashino K, Kishino J, Kikuchi N, Ohara O, Arita $\mathrm{H}$. Molecular cloning of pancreatic group I phospholipase A2 receptor. J Biol Chem 1994; 8: 5897 5904.

68 Moestrup SK, Gliemann J, Pallesen G. Distribution of the $\alpha_{2}$-macroglobulin receptor/ low density lipoprotein receptorrelated protein in human tissues. Cell Tissue Res 1992; 269: 375-382.

69 Chatelet F, Brianti E, Ronco P, Roland J, Verroust P. Ultrastructural localization by monoclonal antibodies of brush border antigens expressed by glomeruli. II Extrarenal distribution. Am J Pathol 1986; 122: 512-519.

70 Multhaupt H A B, Gafvels M E, Kariko K, Jin H, ArenasElliott C, Goldman B I, Strauss J F, Angelin B, Warhol M J, McCrae K R. Expression of very low density lipoprotein receptor in the vascular wall. Analysis of human tissues by in situ hybridization and immunohistochemistry. Am J Pathol 1996; 148: 1985-1997.

71 Stahl P D, Somsel Rodman J, Miller M J, Schlesinger P H. Evidence for receptor-mediated binding of glycoproteins, glycoconjugates, and lysosomal glycosidases by alveolar macrophages. Proc Nat Acad Sci USA 1978; 75: 13991403.

72 Shepherd V L, Lee Y C, Schlesinger P H, Stahl P D. Lfucose-terminated glycoconjugates are recognized by pinocytosis receptors on macrophages. Proc Nat Acad Sci USA 1981; 78: 1019-1022. 
73 Ullrich K, Gieselmann V, Mersmann G, von Figura K. Endocytosis of lysosomal enzymes by non-parenchymal rat liver cells. Biochem J 1979; 182: 329-335.

74 Steer C J, Kusiak J W, Brady R O, Jones E A. Selective hepatic uptake of human B-hexosaminidase $A$ by a specific glycoprotein recognition system on sinusoidal cells. Proc Nat Acad Sci USA 1979; 76: 2774-2778.

75 Stahl P, Schlesinger P H, Sigardson E, Rodman J S, Lee $Y$ C. Receptor-mediated pinocytosis of mannose glycoconjugates by macrophages: characterization and evidence for receptor recycling. Cell 1980; 19: 207-215.

76 Wileman $T$, Boshans R L, Schlesinger $P$, Stahl $P$ Monensin inhibits recycling of macrophage mannoseglycoprotein receptors and ligand delivery to lysosomes. Biochem J 1984; 220: 665-675

77 Hoppe C A, Lee Y C. Accumulation of a nondegradable mannose ligand within rabbit alveolar macrophages. Receptor reutilization is independent of ligand degradation. Biochemistry 1984; 33: 1723-1730.

78 Haltiwanger R S, Hill R L. The ligand binding specificity and tissue localization of a rat alveolar macrophage lectin. J Biol Chem 1986; 261: 15696-15702.

79 Lennartz M R, Cole F S, Shepherd V L, Wileman T E, Stahl P D. Isolation and characterization of a mannosespecific endocytosis receptor from human placenta. J Biol Chem 1987; 262: 9942-9944

80 Taylor M E, Conary J T, Lennartz M R, Stahl P D, Drickamer K. Primary structure of the mannose receptor contains multiple motifs resembling carbohydraterecognition domains. J Biol Chem 1990; 265: 2156-12162.

81 Taylor M E, Bezouska K, Drickamer K. Contribution to ligand binding by multiple carbohydrate-recognition domains in the macrophage mannose receptor. J Biol Chem 1992; 267: 1719-1726.

82 Kruskal B A, Sastry K, Warner A B, Mathieu C E, Ezekowitz $R$ A. Phagocytotic chimeric receptors require both transmembrane and cytoplasmatic domains from the mannose receptor. J Exp Med 1992; 176: 1673-1680.

83 Taylor M E, Drickamer K. Structural requirements for high affinity binding of complex ligands by the mannose receptor. J Biol Chem 1993; 268: 399-404.

84 Mullin N P, Hall K T, Taylor M E. Characterization of ligand binding to a carbohydrate-recognition domain of the macrophage mannose receptor. J Biol Chem 1994; 269 : 28405-28413.

85 Koster A, van Figura K, Pohlmann R. Mistargeting of lysosomal enzymes in $\mathrm{Mr} 46000$ mannose-6-phosphate receptor deficient mice is compensated by carbohydratespecific endocytotic receptors. Eur J Biochem 1994; 224 : 685-689.

86 Smedsrød B, Tollersrud O K. Sinusoidal liver endothelial cells recruit lysosomal enzymes from the circulation by mannose-receptor mediated endocytosis. In: Wisse $E$, Knook D L, Wake K (eds.) Cells of the hepatic sinusoid. Vol 5 Leiden: The Kupffer Cell Foundation, 1995: 180-183.

87 Earnshaw J S. Curtis C G, Powell G M, Dodgson K S, Olavesen A $H$, Gacesa $P$. The fate of intravenously administered highly purified bovine testicular hyaluronidase (hyalosidase) in the rat. Biochem Pharmacol 1985; 34: 2199-2203.

88 Niesen T E, Alpers D H, Stahl P D, Rosenblum J L. Metabolism of glycosylated human salivary amylase: in vivo plasma clearance by rat hepatic endothelial cells and in vitro receptor mediated pinocytosis by rat macrophages. J Leuk Biol 1984; 36: 307-320.

89 Shepherd V L, Hoidal J R. Clearance of neutrophil-derived myeloperoxidase by the macrophage mannose receptor. Am J Respir Cell Mol Biol. 1990; 2: 335-340.
90 Munoz A, Serrano C, Garcia-Estan J, Quesada T, Miras M $T$. Effect of diabetic hyperglycemia and other sugars on plasma dopamine-ß-hydroxilase activity. Diabetes 1984; 33: 1127-1132.

91 Klegeris A, Budd T C, Greenfield S A Acetylcholinesterase-induced respiratory burst in macrophages: evidence for the involvement of the macrophage mannose-fucose receptor. Biochim Biophys Acta 1996; 1289: 159-168

92 Kouyoumdjian M, Birges D R, Prado E S, Prado J L. Identification of receptors in the liver that mediate endocytosis of circulating tissue kallikreins. Biochim Biophys Acta 1989; 980: 299-304

93 Kim S, Hiruma M, Ikemoto F, Yamamoto K. Importance of glycosylation for hepatic clearance of renal renin. Am J Physiol 1988; 255: E642-E651.

94 Marks D I, Kost L J, Kuntz S M, Romero J C, La Russo N $F$. Hepatic processing of recombinant human renin: mechanisms of uptake and degradation. Am J Physiol 1991; 261: G349-G358.

95 Murai $M$, Aramaki $Y$. Tsuchiya S. Identification of the serum factor required for liposome-primed activation of mouse peritoneal macrophages. Modified $\alpha_{2}$-macroglobulin enhances Fcy receptor-mediated phagocytosis of opsonized sheep red blood cells. Immunology 1995; 86: 64-70.

96 Smedsrød B, Melkko J, Risteli L, Risteli J. Circulating Cterminal propeptide of type I procollagen is cleared mainly via the mannose receptor in liver endothelial cells. Biochem J 1990: $271: 345-350$

97 Saunders P T K, Renegar R H, Raub T J, Baumbach G A Atkinson $\mathrm{P} \mathrm{H}$, Bazer $\mathrm{F} \mathrm{W}$, Roberts $\mathrm{R} \mathrm{M}$. The carbohydrate structure of porcine uteroferrin and the role of the high mannose chains in promoting uptake by the reticuloendothelial cells of the fetal liver. J Biol Chem 1985; 260: 3658-3665.

98 Ofec I, Goldhar J, Keisari Y, Sharon N. Nonopsonic phagocytosis of microorganisms. Annu Rev Microbiol 1995; 49: 239-276.

99 Schlesinger L S. Role of mononuclear phagocytes in $M$. Tuberculosis pathogenesis. J Invest Med 1996; 44: 312 323.

100 Giaimis J, Lombard Y, Fonteneau P, Muller C D, Levy R, Makaya-Kumba M, Lazdins J, Poindron P. Both mannose and B-glucan receptors are involved in phagocytosis of unopsinized, heat-killed Saccharomyces Cerevisiae by murine macrophages. J Leuk Biol 1993; 54: 564-571.

101 Kahn S, Wleklinski M, Aruffo A, Farr A, Coder D, Kahn M. Trypanosoma Cruzi amastigote adhesion to macrophages is facilitated by the mannose receptor J Exp Med 1995; 182: 1243-1258.

102 Magnussen S, Kjeken R, Berg T. Characterization of two distinct pathways of endocytosis of ricin by rat liver endothelial cells. Exp Cell Res 1993; 205: 118-125.

103 Mukhopadhyay A, Stahl P. Bee venom phospholipase A2 is recognized by the macrophage mannose receptor. Arch Biochem Biophys 1995; 324: 78-84.

104 Boyle D, Tien L, Cooeper N G F, Shepherd V, McLaughlin $B$ J. A mannose receptor is involved in retinal phagocytosis. Invest Ophtalmol Vis Sci 1991;32: 14641470.

105 Dini L, Ruzittu M T, Vergine M C, Sozzo A, Montinari M R, Falasca $L$. Role of the carbohydrate-specific receptor of liver in the recognition of apoptotic cells: an electron microscopic study on in situ rat livers and isolated endothelial and Kupffer cells. In: Wisse E, Knook D L Wake $\mathrm{K}$ (eds.) Cells of the hepatic sinusoid. Vol 5 Leiden: The Kupffer Cell Foundation, 1995: 85-87. 
106 Falasca L, Bergamini A, Serafino A, Balabaud C, Dini L. Human Kupffer cell recognition and phagocytosis of apoptotic peripheral blood lymphocytes. Exp Cell Res 1996; 224: 152-162.

107 Williams S E, Kounnas M Z, Argaves K M, Argaves S, Strickland D K. The $\alpha_{2}$-macroglobulin/ low density lipoprotein receptor-related protein and the receptor associated protein. Ann N Y Acad Sci 1994; 737: 1-13.

108 Kounnas M Z, Henkin J, Argraves W S, Strickland D K. Low density lipoprotein receptor-related protein/ $\alpha_{2}$ Macroglobulin receptor mediates cellular uptake of prourokinase. J Biol Chem 1993; 268: 21862-21867.

109 Nykjaer A, Kjoller L, Cohen R L, Lawrence D A, Gliemann $\mathrm{J}$, Andreasen $\mathrm{PA}$. Both pro-uPA and UPA:PAl-1 complex bind to the $\alpha_{2}$-macroglobulin receptor/low density lipoprotein receptor-related protein. Evidence for multiple independent contacts between the ligands and receptor. Ann N Y Acad Sci 1994; 737: 483-485.

110 Nykjaer A, Kjoller L, Cohen R L, Lawrence D A, GarniWagner B A, Todd III R F, van Zonneveld A J, Gliemann J, Andreassen P A. Regions involved in binding of urokinasetype-1 inhibitor complex and pro-urokinase to the endocytotic $\alpha_{2}$-macroglobulin receptor/ow density lipoprotein receptor-related protein. J Biol Chem 1994; 269 : 25668-25676.

111 Stefansson S, Lawrence D A, Argraves W S. Plasminogen activator inhibitor-1 and vitronectin promote the cellular clearance of thrombin by density lipoprotein receptorrelated protein. J Biol Chem 1996; 271: 8215-8220.

112 Kounnas M Z, Church F C, Argraves W S, Strickland D K. Cellular internalization and degradation of antithrombin IIIthrombin, heparin cofactor II-thrombin, and $\alpha 1$-antitrypsintrypsin complexes is mediated by the low density lipoprotein receptor-related protein. J Biol Chem 1996; 271: 6523-6529.

113 Wu S M, Pizzo S V. Low-density lipoprotein receptorrelated protein $/ \alpha_{2}$-macroglobulin receptor on murine peritoneal macrophages mediates the binding and catabolism of low-density lipoprotein. Arch Biochem Biophys 1996; 326: 39-47.

114 Chen H, Strickland D K, Mosher D F. Metabolism of thrombospondin 2. Binding and degradation by $3 \mathrm{~T} 3$ cells and glycosaminoglycan-variant Chinese hamster ovary cells. J Biol Chem 1996; 271: 15993-15999.

115 Praaning-van Dalen D P, de Leeuw A M, Brouwer A, Knook D L. Rat liver endothelial cells have a greater capacity than Kupffer cells to endocytose $\mathrm{N}$ acetylglucosamine- and mannose- terminated glycoproteins. Hepatology 1987; 7: 672-679.

116 Sallusto F, Cella M, Danieli C, Lanzavecchia A. Dendritic cells use macropinocytosis and the mannose receptor to concentrate macromolecules in the major histocompatibility complex class II compartment: Downregulation by cytokines and bacterial products. J Exp Med 1995; 182: 389-400.

117 McNally A K, DeFife K M, Anderson J M. Interleukin-4induced macrophage fusion is prevented by inhibitors of mannose receptor activity. Am J Pathol 1996; 149: 975985.

118 Weston S A, Parish C R. Evidence that mannose recognition by splenic sinusoidal cells plays a role in the splenic entry of lymphocytes. Eur J Immunol 1992; 22 : 1975-1981.

119 Benoff S, Hurley I, Cooper G W, Mandel F S, Hershlag A, Scholl $G M$, Rosenfeld D L. Fertilization potential in vitro is correlated with head-specific mannose-ligand receptor expression, acrosome status and membrane cholesterol content. Hum Repr 1993; 8: 2155-2166.
120 Paqûes $E$ P, Just $M$, Reiner G, Romisch J. Pharmacological and pharmacokinetic properties of a deglycosylated mutant of tissue-type plasminogen activator expressed in $\mathrm{CHO}$ cells. Fibrinolysis 1992; 6: 125-130.

121 Kery V, Krepinsky J J F, Warren C D, Capek P, Stahl P D. Ligand recognition by purified human mannose receptor. Arch Biochem Biophys 1992; 298: 49-55.

122 Ohsumi Y, Hoppe C A, Ogawa T, Lee Y C. Enhancement of macromolecular ligand binding by rabbit alveolar macrophages by mannose oligosaccharides and related compounds. Arch Biochem Biophys 1988; 260: 241-249.

123 Robbins J C, Lam M H, Tripp C S, Bugianesi R L, Ponpipom M M, Shen T Y. Synthetic glycopeptide substrates for receptor-mediated endocytosis by macrophages. Proc Nat Acad Sci 1981; 78: 7294-7298.

124 Maynard $Y$, Baenziger J U. Oligosaccharide specific endocytosis by isolated rat hepatic reticuloendothelial cells. J Biol Chem 1981; 256: 8063-8068.

125 Muchmore A V, Sathyamoorthy N, Decker J, Sherblom A $P$. Evidence that specific high-mannose oligosaccharides can directly inhibit antigen-driven T-cell responses. J Leuk Biol 1990; 48: 457-464.

126 Biessen E A L, Noorman F, van Teijlingen M E, Kuiper J, Barrett-Bergshoeff M M, Bijsterbosch M K, Rijken D C, van Berkel Th J C. Lysine-based cluster mannosides that inhibit ligand binding to the human mannose receptor at nanomolar concentration. J Biol Chem 1996; 271: 2802428030. Chapter 6 of this thesis.

127 Herz J, Willnow T E. Functions of the LDL receptor gene family. Ann N Y Acad Sci 1994; 737: 14-19.

128 Herz J. The LDL-receptor-related protein - portrait of a multifunctional receptor. Curr Opin Lipidol 1993; 4: 107 113.

129 Andreasen P A, Sottrup-Jensen L, Kjoller L, Nykjaer A, Moestrup S K, Petersen C M, Gliemann J. Receptormediated endocytosis of plasminogen activators and activator/inhibitor complexes. FEBS letters 338: 239-245.

130 Gliemann J, Nykjaer A, Petersen C M, Jorgensen K E, Nielsen M, Andreasen P A, Christensen E I, Lookene A, Olivecrona G, Moestrup $S \mathrm{~K}$. The multiligand $\alpha_{2}-$ macroglobulin receptor/ow density lipoprotein receptorrelated protein. $\left(\alpha_{2}\right.$ MR/LRP) Binding and endocytosis of fluid phase and membrane-associated ligands. Ann N Y Acad Sci 1994; 737: 20-38.

131 Warshawsky I, Bu G, Schwartz A L. LRP and the receptormediated endocytosis of plasminogen activators. Ann N Y Acad Sci 1994; 737: 70-87.

132 Herz J, Goldstein J L, Strickland D K, Ho Y K, Brown M S. 39-kDa protein modulates binding of ligands to low density lipoprotein receptor related protein/ $\alpha_{2}$-macroglobulin receptor. J Biol Chem 1991; 266: 21232-21238.

133 Moestrup S K, Nielsen S, Andreasen P, Jorgensen K E, Nykjaer A, Roigaard $\mathrm{H}$, Gliemann J, Christensen E I. Epithelial glycoprotein-330 mediates endocytosis of plasminogen activator-plasminogen activator inhibitor type1 complexes. J Biol Chem 1993; 268: 16564-16570.

134 Argraves K M, Battey F D, McCalman C D, McCrae K R, Gafvels M, Kozarsky K F, Chappell D A, Strauss III J F, Strickland D K. The very low density lipoprotein receptor mediates the cellular catabolism of lipoprotein lipase and urokinase-plasminogen activator inhibitor type 1 complexes. J Biol Chem 1995; 270: 26550-26557.

135 Grobmeier S R, Kuo A, Orishimo M, Okada S S, Cines D $B$, Barnathan $E S$. Determinants of binding and internalisation of tissue-type plasminogen activator by human vascular smooth muscle and endothelial cells. J Biol Chem 1993; 268: 13291-13300.

136 Mulder M, Kohnert U, Fisher S, van Hinsbergh V W M, 
Verheijen $\mathrm{J} \mathrm{H}$. The interaction of recombinant tissue type plasminogen activator and recombinant plasminogen activator ( $\mathrm{r}$-PA/ BM 06.022) with human endothelial cells. Blood Coag Fibrin 1997; 8:1-10.

137 Willnow T E, Orth K, Herz J. Molecular dissection of ligand binding sites on the low density lipoprotein receptor-related protein. J Biol Chem 1994; 269: 15827-15832.

138 Orth K, Wilnow T, Herz J, Gething M J, Sambrook J. Low density lipoprotein receptor-related protein is necessary for the internalization of both tissue-type plasminogen activator-inhibitor complexes and free tissue-type plasminogen activator. J Biol Chem 1994; 269: $21117-$ 21122

139 Moestrup S K, Holtet T L, Etzerodt M, Thogersen H C, Nykjaer A, Andreasen P A, Rasmussen $H$ H, SottrupJensen L, Gliemann J. $\alpha_{2}$-macroglobulin-proteinase complexes, plasminogen activator inhibitor type-1plasminogen activator complexes, and receptor-associated protein bind to a region of the $\alpha_{2}$-macroglobulin receptor containing a cluster of eight complement-type repeats. $J$ Biol Chem 1993; 268: 13691-13696.

140 Kuiper J, Vandebilt H, Martin U, van Berkel Th J C. Uptake, internalization and degradation of the novel plasminogen activator reteplase (BM 06.022) in the rat. Thromb Haemostas 1995; 74: 1501-1510.

141 Camani C, Bachmann F, Kruithof E K O. The role of plasminogen activator inhibitor type 1 in the clearance of tissue-type plasminogen activator by rat hepatoma cells. $J$ Biol Chem 1994; 269: 5770-5775.

142 Higgins D L, Bennett W F. Tissue plasminogen activator: the biochemistry and pharmacology of variants produced by mutagenesis. Ann Rev Pharmacol Toxicol 1990; 30: 91121.

143 Otter M, van Berkel Th J C, Rijken D C. Binding and degradation of tissue-type plasminogen activator by the human hepatoma cell line Hep G2. Thromb Haemostas 1989; 62: 667-672.

144 Kuiper J, van 't Hof A, Otter M, Biessen E A L, Rijken D C, van Berkel Th J C. Interactions of mutants of tissue-type plasminogen activator with liver cells, effect of domain deletions. Biochem J 1996; 313: 775-780.

145 Kuiper J, Otter M, Voorschuur A H, van Zonneveld A J, Rijken D C, van Berkel Th J C. Characterization of the interaction of a complex of tissue-type plasminogen activator and plasminogen activator inhibitor type 1 with rat liver cells. Thromb Haemostas 1995; 74: 1298-12304.

146 Horn I R, Moestrup S K, van den Berg B M M, Pannekoek $\mathrm{H}$, Nielsen M S, van Zonneveld A J. Analysis of the binding of pro-urokinase and urokinase-plasminogen activator inhibitor-1 complex to the low density lipoprotein receptorrelated protein using a Fab fragment selected from a phage-displayed Fab library. J Biol Chem 1995; 270: 11770-11775.

147 Wing $L$ R, Bennett $B$, Booth N A. The receptor for tissuetype plasminogen activator ( $t-P A)$ in complex with its inhibitor, PAI-1, on human hepatocytes. FEBS Lett 1991; 278: 95-97.

148 Wing LR, Hawksworth GM, Bennett B, Booth NA. Clearance of t-PA, and t-PA-PAl-1 complex in an isolated perfused rat liver system. J Lab Clin Med 1991; 117: 109114.

149 Juhan-Vague I, Chandler W L, Aillaud M F, Alessi M C, Vague $P$, Henderson $P$. Humans clear active t-PA faster than IPAPAl-1 complex. Fibrinolysis 1996; 10, Suppl 3: 102. (abstract)

150 Chandler W L, Levy W C, Stratton J R. The circulatory regulation of TPA and UPA secretion, clearance, and inhibition during exercise and during the infusion of isoproterol and phenylepinephrine. Circulation 1995; 92: 2984-2994

151 Shepherd V L, Campbell E J, Senior R M, Stahl P D. Characterization of the mannose/fucose receptor on human mononuclear phagocytes. I Reticuloendoth Soc 1982; 32: 423-431.

152 Stein M, Keshav S, Harris N, Gordon S. Interleukin 4 potently enhances murine macrophage mannose receptor activity: a marker of alternative immunologic macrophage activation. J Exp Med 1992; 176: 287-292.

153 Doyle A G, Herbein G, Montaner L J, Minty A J, Caput D, Ferrera $P$, Gordon $S$. Interleukin-13 alters the activation state of murine macrophages in vitro: comparison with interleukin-4 and interferon-y Eur J Immunol 1994; 24: 1441-1445.

154 Schreiber S, Perkins S L, Teitelbaum S L, Chappel J, Stahl $P D$, Blum J $S$. Regulation of mouse bone marrow macrophage mannose receptor expression and activation by prostaglandin E and IFN-Y. J Immunol 1993; 151: 49734981.

156 Shepherd V L, Konish M G, Stahl P. Dexamethasone increases expression of mannose receptors and decreases extracellular lysosomal enzyme accumulation in macrophages. J Biol Chem 1985; 260: 160-164.

157 Cowan H B, Vick S, Conary J T, Shepherd V L. Dexamethasone up-regulates mannose receptor activity by increasing mRNA levels. Arch Biochem Biophys 1992; 296: 314-320.

158 Imber M J, Pizzo S V, Johnson J, Adams D O. Selective diminution of the binding of mannose receptor by murine macrophages in the late stages of activation. J Biol Chem 1982; 257: 5129-5135.

159 Shepherd V L, Abdorasulnia R, Garrett M, Cowan H B. Down-regulation of mannose receptor activity in macrophages after treatment with lipopolysaccharide and phorbol esters. J Immunol 1990; 145: 1530-1536.

160 Bozeman P M, Hoidal J R, Shepherd V L. Oxidantmediated inhibition of ligand uptake by the macrophage mannose receptor. J Biol Chem 1988; 263: 1240-1247.

161 Shepherd V L, Abdorasulnia R, Stephenson J, Crenshaw C. Modulation of mannose receptor activity by proteolysis. Biochem J 1990; 270: 771-776.

162 Schreiber S, Perkins S L, Teitelbaum S L, Chappel J, Stahl $P D$, Blum J $S$. Regulation of mouse bone marrow macrophage mannose receptor expression and activation by prostaglandin E and IFN-y. J Immunol 1993; 151: 49734981.

163 Shepherd V L, Cowan H B, Abdolrasulnia R, Vick S. Dexamethasone blocks the interferon- $y$-mediated downregulation of the macrophage mannose receptor. Arch Biochem Biophys 1994; 312: 367-374.

164 Martinez I, Sveinbjørnsson B, Vidal-Vanaclocha $F$, Asumendi A, Smedsrød B. Differential cytokine-mediated modulation of endocytosis in rat liver endothelial cells. Biochem Biophys Res Commun 1995; 212: 235-241.

165 Dini L, Lentini A, Conti L, Devergilis L C. Binding and uptake of ligands for mannose-specific receptors in liver cells: an electron microscopic study during development and aging in rat. Mech Age Developm 1990; 56: 117-128.

166 W eiel J E, Salvatore V P. Down regulation of macrophage mannose/ $\mathrm{N}$-acetylglucosamine receptors by elevated glucose concentrations. Biochim Biophys Acta 1983; 759: 170-175.

167 Pizzo S V, Lehrman M A, Imber M J, Guthrow C E. The clearance of glycoproteins in diabetic mice. Biochem Biophys Res Commun 1981; 101: 704-708.

168 Summerfield J A, Vergalla J, Jones E A. Modulation of a glycoprotein recognition system on rat hepatic endothelial 
cells by glucose and diabetes mellitus. J Clin Invest 1982; 69: 1337-1347.

169 Kancha R K, Hussain M M. Up-regulation of the low density receptor-related protein by dexamethasone in Hep G2 cells. Biochim Biophys Acta 1996; 1301:213-220

170 Descamps O, Bilheimer D, Herz J. Insulin stimulates receptor-mediated uptake of apo-E-enriched lipoproteins and activated $\alpha_{2}$-macroglobulin in adipocytes. J Biol Chem 1993; 268: 974-981.

171 Anfosso F, Bannwarth S, Alessi M C, Peiretti F, JuhanVague I. Insulin up-regulates the synthesis of the low density lipoprotein-related protein (LRP) and the uptake of t-PA/PAl-1 complexes in HEP G2 cells. Fibrinolysis 1996; 10, Suppl 3: 33 (abstract)

172 Cohen A F, Burggraaf K, de Boer A, Kluft C. Clearance of plasminogen activators - A major determinant of plasma concentration: therapeutic and diagnostic implications. Ann N Y Acad Sci 1992; 667: 443-449.

173 Leiper K, Croll A, Booth N A, Moore N R, Sinclair T, Bennett B. Tissue plasminogen activator, plasminogen activator inhibitors, and activator-inhibitor complex in liver disease. J Clin Pathol 1994; 47: 214-217.

174 Piatkowska M, Kotchy M, Halota W. The fibrinolytic activity in blood of patients with liver cirrhosis. Fibrinolysis 1996; 10, Suppl 3: 51. (abstract)

175 Hultberg B, Isakson A, Tiderstrom G. B-hexosaminidase, leucine aminopeptidase, cystidyl aminopeptidase, hepatic enzymes and bilirubin in serum of chronic alcoholics with acute ethanol intoxication. Clin Chim Acta 1980; 105: 317323.

176 Eliasson M, Evrin P E, Lundblad D, Asplund K, Ranby M. Influence of gender, age and sampling time on plasma fibrinolytic variables and fibrinogen. A population study. Fibrinolysis 1993; 7: 316-323.

177 Lombardo A, Goi G C, Marchesini S, Luigi C, Moro M, Tettamanti $G$. Influence of age and sex on five human plasma lysosomal enzymes assayed by automated procedures. Clin Chim Acta 1981; 113: 141-152.

178 Goi G. Bairati C, Roggi C, Maccarini L, Tettamanti G, Meloni C, Lombardo A. The lysosomal N-acetyl-B-Dglucosaminidase (NAG) isoenzymes in plasma: study of distribution in a general population by a simple routine chromatofocusing procedure. Clin Chim Acta 1993; 321: 47-57.

179 Stegnar M, Zore A, Novak-Antolic Z, Vovk N, Kruithof E K $O$. Tissue-type plasminogen activator after venous occlusion in pregnancy and puerperium. Thromb Haemostas 1993; 70: 486-490.

180 Juhan-Vague I, Alessi M C, Raccah D, Aillaud M F, Billerey $M$, Ansaldi J, Philip-Joet $C$, Vague P. Daytime fluctuations of plasminogen activator inhibitor 1 (PAI-1) in populations with high PAl-1 levels. Thromb Haemostas 1992; 67: 76-82.

181 Hultberg B, Isaksson A. A possible explanation for the occurrence of increased B-hexosaminidase activity in pregnancy serum. Clin Chim Acta 1981; 113: 135-140.

182 Lombardo A, Goi G C, Pistolesi E, Rocca A, Agosti S, Fabi A, Giuliani A, Burlina A B, Tettamanti G. Behaviour of several enzymes of lysosomal origin in human plasma during pregnancy. Clin Chim Acta 1984; 143: 253-264.

183 Folsom A R, Qamhieh H T, Wing R R, Jeffery R W, Stinson V L, Kuller L H, Kenneth K W. Impact of weight loss on plasminogen activator inhibitor (PAI-1), factor VII, and other haemostatic factors in moderately overweight adults. Arterioscl Thromb 1993; 13: 162-169.

184 Corral J, Mirrales J M, Garcia-Pascual I J, Corrales I J, Garcia-Sastre A, Villar E. Increased serum N-acetyl-Bglucosaminidase and $\alpha$-mannosidase activities in obese subjects. Clin Invest 1992; 70: 880-884.

185 Padro T, van den Hoogen C M, Emeis J J. Changes in tissue content and hepatic clearance of tissue-type plasminogen activator during diet-induced hyperlipidaemia in rats. Fibrinolysis 1992; 6: 250-255.

186 Poon P Y W, Davis T M E, Dornan T L, Turner R C. Plasma $\mathrm{N}$-acetyl-B-D-glucosaminidase activities and glycemia in diabetes mellitus. Diabetologia 1983; $24: 433$ 436.

187 Waters P J, Flynn M D, Corrall R J M, Pennock C A. Increase in plasma lysosomal enzymes in type 1 (insulindependent) diabetus mellitus: relationship to diabetic complications and glycemic control. Diabetologia 1992; 35 991-995.

188 Skiha J, Hodinar A, Kvasnicka J, Stibor V, Sperl M, Stolba $\mathrm{P}$, Hilgertova J. Early changes of serum $\mathrm{N}$-acetyl- $\mathrm{B}$ glucosaminidase, tissue plasminogen activator and erythrocyte superoxide dismutase in relation to retinopathy in type I diabetes mellitus. Clin Chim Acta 1994; 229: 5-14.

189 Myrup B, Rossing P, Jensen T, Gram J, Kluft C, Jespersen $\mathrm{J}$. The effect of the relationship between tissuetype plasminogen activator and plasminogen activator inhibitor type 1 on tisue-type plasminogen activator activity in insulin-dependent diabetes mellitus. Fibrinolysis 1994; 8 , Suppl 2: 22-24.

190 Jensen T, Bierre-Knudsen J, Feldt-Rasmussen B, Deckert $T$. Features of endothelial dysfunction in early diabetic nephropathy. Lancet 1989; 8636: 461-463.

191 Amiral J, Seigneur M, Vissac A M, Boisseau M, Scarabin $P Y$, Gin $H$. Highly impaired fibrinolysis in non-insulin dependent but not in insulin-dependent diabetes.(thrombocheck study) Fibrinolysis 1996; 10 , Suppl 3: 87. (abstract)

192 Juhan-Vague I, Vague P, Poisson C, Aillaud M F, Mendez C, Collen D. Effect of 24 hours of normoglycemia on tissue-type plasminogen activator plasma levels in insulindependent diabetes. Thromb Haemostas 1984; 51: 97-98.

193 Kluft C, Potter van Loon B J, de Maat M P M. Insulin resistance and changes in haemostatic variables. Fibrinolysis 1992; 6, Suppl 3: 11-6

194 Landin K, Tengborn L, Smith U. Treating insulin resistance in hypertension with metformin reduces both blood pressure and metabolic risk factors. J Intern Med 1991; 229: 181-187.

195 Gough S C L, McCormack L, Rice P J S, Grant P J. The fibrinolytic response to exercise at diagnosis and after 12 months in patients with type 2 diabetes mellitus. Fibrinolysis 1994; 8: 372-377.

196 Erickson L A, Marotti K R. Design of novel thrombolytic agents via domain modifications. Toxicol Pathol 1990; 18 : 597-602.

197 Thomas G R, Thibodeaux H, Errett C J, Badillo J M, Wu D $T$, Refino C J, Key B A, Bennett W F. Limiting systemic plasminogenolysis reduces the bleeding potential for tissue-type plasminogen activators but not for streptokinase. Thromb Haemostas 1996; 76:915-920.

198 Potyk D K, Tabbarah H J. The pathogenesis and prevention of thromboembolic complications. in patients undergoing total hip replacement. J Gener Int Med 1993; 8: 213-219.

199 Dubick M A, Wade C E A. A review of the efficacy and safety of $7.5 \% \mathrm{NaCl} / 6 \%$ dextran 70 in experimental animals and in humans J Trauma 1994; 36: 323-330.

200 Eriksson M, Saldeen T. Effect of dextran on plasma tissue plasminogen activator (t-PA) and plasminogen activator inhibitor-1 (PAl-1) during surgery. Acta Anaestesiol Scand 1995; 39: 163-166. 


\title{
SUMMARY
}

\section{The mannose receptor, localization and role in the clearance of tissue-type plasminogen activator.}

\begin{abstract}
After damage to a blood vessel a blood clot is formed (coagulation) and after tissue repair the clot is degraded (fibrinolysis). Coagulation and fibrinolysis are controlled by production of enzymes and enzyme inhibitors. The balance between these processes determines whether the clot is formed or degraded. Tissue-type plasminogen activator (t-PA) is an enzyme which converts plasminogen into plasmin, which in turn converts the insoluble network of the blood clot, fibrin, into soluble fibrin degradation products. Plasma t-PA is continuously synthesized and secreted by the endothelial cells that line the blood vessels, and continuously degraded (clearance) by the liver.
\end{abstract}

The clearance of t-PA by the liver is very efficient; within 5 minutes half of an injected dose of t-PA has disappeared from the plasma. The clearance of t-PA by the liver is a receptor-mediated process. $t-P A$ binds to receptors expressed on the surface of cells in the liver. After binding the receptor-t-PA complex is internalized, t-PA is degraded in the cell and the receptor is recycled to the cell surface where it again can bind t-PA. The mannose receptor and the $\alpha_{2}$-macroglobulin receptor (also called the low density lipoprotein receptor-related protein (LRP)) are mainly responsible for the clearance of t-PA by the liver. When a clot is formed t-PA is incorporated into the clot. The more t-PA is incorporated the higher the lysability of the clot. A high concentration of t-PA shifts the balance of coagulation and fibrinolysis towards fibrinolysis. Therefore recombinant t-PA is successfully used as a thrombolytic drug for instance after myocardial infarction and low dosage infusion of t-PA may be useful in antithrombotic therapy.

In this thesis we hypothesized that inhibitors of the mannose receptor-t-PA binding might decrease the clearance of t-PA. By inhibition of the clearance it might be possible to increase the efficacy of exogenous and endogenous t-PA. These inhibitors could thus be useful drugs in thrombolytic and antithrombotic therapy. The aim of this study was to extend our knowledge of the mannose receptor in order to develop efficient mannose receptor inhibitors. These inhibitors may in the future be used to treat thrombotic (and other) diseases. 


\section{Study design}

To evaluate the human mannose receptor-t-PA interaction and to characterize the efficacy of inhibitors we developed two in vitro assays (chapter 1 and 2). Monoclonal antibodies (mAb) against the human mannose receptor were developed to specifically study the mannose receptor that is able to bind t-PA (chapter 3). To assess the possible role(s) of the mannose receptor in man, these mAb were used to visualize the mannose receptor expression on cells in vitro and in human tissues under physiological and pathological conditions (chapter 4 and 5). The inhibitory efficacy of newly synthesized mannose receptor ligands and the antithrombotic agent dextran was tested in vitro and in vivo (chapter 6,7 and 8). In the last chapter (chapter 9) the results of this study are discussed and the regulation of plasma t-PA concentrations by receptor-mediated clearance is reviewed.

\section{In vitro models of the interaction between the human mannose receptor and $t-P A$}

The mannose receptor contains multiple carbohydrate recognition domains. The more carbohydrate binding sites the ligand binds to, the higher the affinity of the ligand. Previous research showed that the high mannose-type oligosaccharide (a carbohydrate polymer with three terminal mannose residues) of t-PA binds to the mannose receptor. In chapter 1 we further characterized the interaction of t-PA with the isolated human mannose receptor. The mannose receptor was isolated from human placenta, and the binding of t-PA and t-PA variants was measured in a microtitre plate binding assay. Compared to two other glycoproteins, ribonuclease $B$ and ovalbumin, that also contain a high mannose-type oligosaccharide, t-PA binds with a much higher (500 times) affinity to the human mannose receptor. The binding of $t-P A$ to the mannose receptor was specific since the binding was fully inhibited by mannan (a polymer of mannose) or by polyclonal antibodies against the mannose receptor. Since a variant of t-PA that did not contain oligosaccharides did not inhibit the binding of t-PA to the mannose receptor, it is unlikely that protein-protein interactions contribute significantly to the high affinity binding of t-PA. Complex formation of t-PA with plasminogen activator inhibitor type 1 (PAl-1) or $\alpha_{2}$-antiplasmin did not affect the affinity of t-PA for the mannose receptor. Furthermore the complex-type oligosaccharides or the O-linked fucose residue of t-PA were not involved in the high affinity of t-PA.

The protein moieties of t-PA, ribonuclease $B$ and ovalbumin were fully digested with trypsin, an enzyme that does not digest the oligosaccharides of the glycoproteins. The trypsin digest of t-PA had a 500 -fold lower affinity than intact t-PA, whereas trypsin digests of ribonuclease $B$ and ovalbumin only had a 2 to 3 times lower affinity than the intact glycoproteins. This indicated that the high mannose-type oligosaccharide of t-PA did not bind differently from that of ribonuclease B or ovalbumin to the mannose receptor. It is likely that the conformation of the high mannose-type oligosaccharide of t-PA is influenced by the protein core in such a way that the oligosaccharide binds to more carbohydrate recognition domains of the mannose receptor and thus causes the high affinity of intact t-PA for the mannose receptor. The binding assay with isolated human mannose was in further studies used as an in vitro model to study the efficacy of inhibitors of the mannose receptor-t-PA binding (see chapter $3,6,7,8$ ) 
In chapter 2 we characterized the receptor systems involved in the binding, association and degradation of t-PA by human macrophages in culture. Monocytes were isolated from human buffy coats and cultured. Within two days the monocytes were differentiated to macrophages. At $4^{\circ} \mathrm{C}$ t-PA bound to macrophages with high $(\mathrm{Kd}=1-5 \mathrm{nM})$ and low $(\mathrm{Kd}>350 \mathrm{nM})$ affinity. The low affinity binding sites were inhibited with the lysine analog 6-aminohexanoic acid (6-AHA). At $37^{\circ} \mathrm{C}$ the macrophages internalised and degraded t-PA. This process was partially inhibited by mannan or a monoclonal antibody against the mannose receptor (see chapter 3). The non-mannan-inhibitable degradation of t-PA was inhibited by receptor associated protein (RAP), an inhibitor of LRP. Neither inactivation of t-PA nor the addition of 6 AHA influenced the degradation of t-PA. The degradation of t-PA by monocytes was not mannaninhibitable. The mannose receptor- and LRP-mediated t-PA degradation was upregulated during the differentiation of monocytes to macrophages. Dexamethasone upregulated only the mannose receptormediated t-PA degradation. Lipopolysaccharide downregulated both mannose receptor-mediated and LRP-mediated t-PA degradation. We concluded that human macrophages use two independently regulated receptors, namely the mannose receptor and LRP, for the uptake and degradation of t-PA. Since these receptors are mainly responsible for the clearance of t-PA in the liver, cultured human macrophages are a suitable in vitro model for evaluating inhibitors of t-PA clearance. Therefore the macrophages were used in further studies to assess the efficacy of inhibitors to inhibit the mannose receptor-mediated t-PA degradation (see chapter $3,7,8$ )

\section{Development and applications of monoclonal antibodies against the human mannose receptor}

A set of five monoclonal antibodies $(\mathrm{mAb})$ was generated against the mannose receptor isolated from human placental tissue and characterized (chapter 3). All mAb specifically recognised the $175 \mathrm{kDa}$ mannose receptor in a crude placenta extract, as shown in Western blot analysis. By use of immunohistochemistry we showed that in human placenta only the Hofbauer cells (fetal macrophages) express the mannose receptor. Cross-competition experiments indicated that the mAb bound to at least two different epitopes on the isolated mannose receptor. One of these epitopes was located closely to the t-PA binding site, since the mAb directed against this epitope strongly inhibited the binding of t-PA to the isolated mannose receptor and the mannose receptor-mediated degradation of $\mathrm{t}-\mathrm{PA}$ by cultured human macrophages.

These mAb were used to study the expression of the mannose receptor on isolated cells and human lymphoid tissues (chapter 4). Isolated human monocytes and lymphocytes did not and cultured macrophages did express the mannose receptor as determined with flow cytometry. The mannose receptor was upregulated on dexamethasone-treated macrophages, and downregulated on lipopolysaccharide-treated macrophages. The mannose receptor expression of a number of cell types involved in the immune system was evaluated by the use of immunohistochemistry (with mAb 15-2). Monocytes, lymphocytes, granulocytes and Langerhans cells were mannose receptor-negative, tissue macrophages in thymus, lymph nodes, bone marrow and skin were mannose receptor-positive. Interestingly the macrophages in the thymus medulla and $T$ cell areas of the lymphodes were mannose receptor-positive, whereas the macrophages in thymus cortex and B cell areas of lymph nodes were mannose receptor-negative. Monocytes can differentiate into antigen-presenting cells (dendritic cells). It has been shown that the mannose receptor is involved in the uptake of antigens by dendritic cells in vitro. When these cells are stimulated to present the antigen to $T$ cells, the mannose receptor is downregulated. In the thymus cortex and the B cell areas antigen is presented by dendritic cells, which could explain the absence of mannose receptor-positive cells in these areas. 
Besides mediating the clearance of glycoproteins that contain high mannose-type oligosaccharides in the liver, the mannose receptor has been shown to be involved in several other processes. In vitro experiments have shown that the mannose receptor is involved in the macrophage complementindependent phagocytosis of pathogens such as Candida and Tuberculosis, and probably is involved in the fusion of macrophages into foreign body-type giant cells, the homing of lymphocytes to the spleen, and sperm fertility. The mannose receptor expression correlates to the type of macrophage activation in vitro; the T-helper type 1 cytokine $y$-interferon activate the macrophage in such a way that the mannose receptor expression is downregulated, whereas the T-helper type 2 cytokines interleukin-4 and interleukin-13 activate the macrophage in such a way that the mannose receptor is upregulated (also called immunosuppression or alternative activation).

In chapter 5 we used one of the mAb (mAb 15-2) to evaluate the tissue distribution of the human mannose receptor under physiological and pathogenic conditions. Only a few cell types expressed the receptor under physiological conditions: resident macrophages in all tissues, liver and spleen sinus endothelial cells, and sperm cells. Some macrophages were mannose receptor-negative: the microglial cells in the brain and the macrophages in the thymus cortex, B cell areas in lymph nodes and spleen. In tissues affected by tuberculosis, leprosy, carcinoma or rheumatoid arthritis the macrophage mannose receptor appeared to be downregulated which indicated that the macrophages were activated, whereas in a reaction against polyethylene the macrophage mannose receptor appeared to be upregulated, which indicated that the macrophages were alternatively activated. It was concluded that in vivo few human cell types express the mannose receptor, and that the mannose receptor expression in vivo also reflects the type of macrophage activation. mAb 15-2 proved to be a specific tool in studying the mannose receptor expression in human tissues.

\section{Inhibitors of the mannose receptor-mediated t-PA clearance}

A series of mannose receptor inhibitors was synthesized. The series consisted of lysine- or polylysinebased oligomannosides containing two $\left(M_{2} L_{1}\right)$ to six $\left(M_{6} L_{5}\right)$ terminal $\alpha$-D-mannose groups that were connected to the backbone by flexible elongated spacers. The efficacy of these cluster mannosides to inhibit the interaction of $\mathrm{t}-\mathrm{PA}$ or ribonuclease $\mathrm{B}$ with the mannose receptor was tested in the microtitre plate binding assay (chapter 6 ). The cluster mannosides all inhibited the binding of t-PA or ribonuclease $B$ completely. The affinity of these inhibitors increased with the number of terminal mannose residues connected to the lysine backbone ( $M_{2} L_{1}$ micromolar range and $M_{6} L_{5}$ nanomolar range). The shape of the inhibition curves indicated that the mannosides bound to multiple carbohydrate recognition domains on the mannose receptor. The nanomolar affinity of $M_{6} L_{5}$ makes it the most potent synthetic mannose receptor ligand yet developed, and besides the inhibition of ligand binding to the mannose receptor it also is a promising targeting device to accomplish cell-specific delivery of drugs (for instance in gene therapy) to cells that express the mannose receptor. 
In chapter 7 we studied whether these cluster mannosides would also be effective t-PA clearance inhibitors in man. By use of immunohistochemistry we showed that, as in the rat liver, the human liver endothelial cells and human Kupffer cells do express the mannose receptor. The mannosides inhibited mannose receptor-mediated t-PA binding, association and degradation by isolated rat liver endothelial cells and t-PA association and degradation by cultured human macrophages with similar affinities. $M_{5} L_{4}$ inhibited t-PA degradation in the micromolar range whereas $M_{6} L_{5}$ was able to inhibit t-PA degradation in the nanomolar range. The concentrations of mannoside necessary to inhibit t-PA degradation in vitro were comparable to the concentrations necessary to inhibit mannose receptor-mediated t-PA clearance in vivo in the rat. Since there was no species difference between rat and man with respect to the distribution of the mannose receptor in the liver and the affinity of the cluster mannosides, it is likely that $M_{6} L_{5}$, as observed in the rat, will be an efficient inhibitor of mannose receptor-mediated t-PA clearance in man.

In chapter 8 we provide evidence for a possible antithrombotic effect of mannose receptor inhibitors in vivo in man. Dextran is a blood substitute with antithrombotic properties. Recently it has been shown that dextran increases the t-PA plasma concentration and activity in patients. Dextran is a glucose polymer and a potential ligand for the mannose receptor.

We studied the effect of dextran on the mannose receptor-t-PA interaction in our in vitro models, and in vivo in the rat. At therapeutic concentrations, dextran was able to inhibit t-PA binding to the isolated receptor and the mannose receptor-mediated t-PA degradation by macrophages, while leaving the LRP-mediated t-PA degradation unaffected. In vivo dextran increased endogenous t-PA concentrations and inhibited exogenous t-PA clearance. Furthermore, the endogenous t-PA concentrations correlated strongly with the clearance of exogenous t-PA. We concluded that the dextran-induced increase of endogenous t-PA concentrations are a result of the inhibition of mannose receptor-mediated t-PA clearance by dextran, which is a new explanation for the antithrombotic effect of dextran.

In chapter 9 the role of the mannose receptor and other clearance receptors in the regulation of t-PA concentrations is discussed. We concluded that the plasma clearance of t-PA is mainly mediated by the mannose receptor and the LRP expressed in the liver. The high mannose-type oligosaccharide of t-PA binds to the mannose receptor; the growth factor and finger domain are involved in the binding of t-PA to the LRP. The expression of these receptors in the liver possibly influences the plasma concentrations of t-PA under (patho)physiological conditions such as ageing, pregnancy, obesity and diabetes. Inhibitors of (mannose receptor-mediated) clearance might be useful in thrombolytic and antithrombotic therapy. 


\section{Conclusions and perspectives}

We developed useful assays and tools to study the $175 \mathrm{kD}$ human mannose receptor and high affinity ligands that are able to inhibit its interaction with t-PA. We showed that the mannose receptor is expressed on macrophages in human tissues, and that its expression depends on the type of macrophage activation. The monoclonal antibodies against the mannose receptor may offer new insights into the role of macrophages in various diseases. The mannose receptor expressed on liver endothelial cells and Kupffer cells plays an important role in the clearance of t-PA. It was demonstrated that mannose receptor ligands could partially inhibit the clearance of exogenous t-PA and increase endogenous t-PA plasma concentrations. Thus mannose receptor ligands such as $M_{6} L_{5}$ can be considered as a new strategy to increase the t-PA concentration in blood and thereby increase the efficacy of thrombolytic and antithrombotic therapy.

The mannose receptor ligands described in this thesis may in the future besides in the treatment of thrombotic diseases also be used in the treatment of other diseases. One can think of connecting drugs to these ligands in order to target the drugs towards mannose receptor-expressing cells (sinusoidal cells in liver and spleen, and macrophages and dendritic cells in all tissues). In combination with a dextran 70 (macrodex) infusion it may be possible to target the ligand-connected drug mainly to the cells residing outside the bloodstream, since dextran inhibits the mannose receptor-mediated clearance and is too large to escape from the bloodstream. In this way drugs may be targetted towards macrophages and dendritic cells. This would make it possible to activate or suppress the immune system. One could, for example, load dendritic cells with cell type-specific antigens in order to activate the immune system to kill these cell types (such as cancer cells or cells that produce autoantibodies). It is a hopeful thought that maybe in the future we will be able to manipulate the immune system in this way. 


\section{SAMENVATTING}

\section{De mannose receptor, localisatie en rol in de klaring van weefseltype plasminogeenactivator.}

$\mathrm{Na}$ beschadiging van een bloedvat wordt een bloedstolsel gevormd en na herstel van het weefsel wordt het stolsel weer afgebroken. Stolselvorming en stolselafbraak worden gecontroleerd door de productie en afbraak van enzymen en enzymremmers. De balans tussen deze processen bepaalt of het stolsel gevormd dan wel afgebroken wordt. Weefseltype plasminogeenactivator (t-PA) is een enzym dat plasminogeen om kan zetten in plasmine, welke de onoplosbare struktuur van een stolsel, fibrine, om kan zetten in oplosbare fibrine afbraak producten. Het t-PA dat in bloed circuleert wordt in het lichaam continu aangemaakt door de endotheelcellen die de bloedvaten bekleden, en continu opgenomen en afgebroken (klaring) door de lever. De klaring van t-PA door de lever is een zeer efficient proces; binnen 5 minuten is de helft van een toegediende dosis t-PA uit de bloedbaan verdwenen. De klaring van t-PA door de lever is een receptor-gemedieerd proces. t-PA bindt aan receptoren die op het oppervlak van de cellen in de lever zitten. Na binding wordt het receptor-t-PA complex opgenomen door de cel, het tPA wordt afgebroken en de receptor keert terug naar het celoppervlak waar het opnieuw t-PA kan binden. Vooral de mannose receptor en de $\alpha_{2}$-macroglobulin receptor (ook wel de "low density lipoprotein receptor-related protein" (LRP) genoemd) zijn verantwoordelijk voor de klaring van t-PA door de lever. Wanneer een bloedstolsel gevormd wordt, wordt t-PA in het stolsel ingebouwd. Hoe meer t-PA in het stolsel zit, hoe sneller het stolsel daarna afgebroken kan worden. Een grote hoeveelheid t-PA kan ervoor zorgen dat de balans van stolselvorming en stolselafbraak doorslaat naar stolselafbraak. Daarom wordt recombinant t-PA succesvol gebruikt als een thrombolytisch medicijn na bijvoorbeeld een hartinfarct, en zou infusie van lage hoeveelheiden t-PA bruikbaar kunnen zijn in antithrombotische therapie.

In dit proefschrift is de hypothese gesteld dat remmers van de mannose receptor-t-PA binding, de klaring van t-PA kunnen remmen. Door remming van de klaring zou de effectiviteit van toegediend of endogeen t-PA verhoogd kunnen worden. Deze remmers zouden dan nuttige medicamenten kunnen zijn in thrombolytische en antithrombotische therapie. Het doel van deze studie was de kennis over de werking en de functie van de mannose receptor te vergroten teneinde effectieve mannose receptor remmers te ontwikkelen. Deze kunnen in de toekomst mogelijk gebruikt worden in de behandeling van thrombotische (en andere) ziektes. 


\section{Opzet van het onderzoek}

Om de humane mannose receptor-t-PA interactie te kunnen karakteriseren en de effectiviteit van remmers te kunnen evalueren ontwikkelden we twee in vitro meetsystemen (hoofdstuk 1 en 2). Monoclonale antilichamen ( $\mathrm{mAb}$ ) tegen de humane mannose receptor werden geproduceerd om specifiek die mannose receptor te kunnen bestuderen die in staat is om t-PA te binden (hoofdstuk 3 ). Om de mogelijke functie(s) van de mannose receptor in de mens vast te kunnen stellen, werden deze $\mathrm{mAb}$ gebruikt om de expressie van de mannose receptor op cellen in vitro en in gezond en ziek humaan weefsel zichtbaar te maken (hoofdstuk 4 en 5). Van een serie synthetische mannose receptor liganden en van het antithrombotische middel dextran, werd de effectiviteit om de mannose receptor-t-PA interactie in bovengenoemde in vitro modellen en in vivo te remmen, getest (hoofdstuk 6, 7 en 8). In het laatste hoofdstuk (hoofdstuk 9) worden de resultaten van deze studie bediscussieerd en wordt een overzicht gegeven van de regulatie van plasma t-PA concentraties door receptor-gemedieerde klaring.

\section{In vitro meetmodellen van de humane mannose receptor-t-PA interactie}

De mannose receptor heeft een aantal suiker herkenningsdomeinen. Hoe meer suiker herkenningsdomeinen van de mannose receptor het ligand binden, hoe hoger de affiniteit van het ligand. Uit voorgaand onderzoek was gebleken dat het hoog mannose-type suiker (een suiker polymeer met 3 eindstandige mannoseresiduen) van t-PA aan de mannose receptor bindt. In hoofdstuk 1 werd de binding van t-PA aan de geisoleerde humane mannose receptor nader gekarakteriseerd. De mannose receptor werd geisoleerd uit humane placenta, en de binding van t-PA en t-PA varianten werd gemeten in een microtiterplaat bindingsassay. Het bleek dat t-PA met een veel hogere (500 maal) affiniteit aan de mannose receptor bindt dan twee andere hoog mannose-type suiker bevattende eiwitten, ribonuclease $B$ en ovalbumine. De binding van t-PA was specifiek aangezien het volledig geblokkeerd kon worden met mannan (een mannose polymeer) of met polyclonale antilichamen tegen de mannose receptor. Het is onwaarschijnlijk dat eiwit-eiwit interacties significant bijdragen aan de hoge affiniteits binding van tPA aan de mannose receptor aangezien een suikerloze t-PA variant de binding van t-PA niet kon remmen. Complex vorming van t-PA met plasminogeen activator remmer type 1 (PAl-1) of $\alpha_{2}$ antiplasmine had geen invloed op de affiniteit van t-PA voor de mannose receptor. Verder bleek dat de complex-type suikers of de fucose suiker van t-PA niet betrokken waren bij de hoge affiniteit van t-PA.

Het eiwit gedeelte van t-PA, ribonuclease B en ovalbumine werd volledig geknipt met trypsine, een enzym dat de suiker polymeren van de eiwitten intact laat. Het trypsine afbraakproduct van t-PA had een 500 -voud lagere affiniteit dan intact t-PA, terwijl de trypsine afbraakproducten van ribonuclease $\mathrm{B}$ en ovalbumine slechts een 2- tot 3-voudige lagere affiniteit dan de intacte eiwitten hadden. Dit gaf aan dat het hoog mannose-type suiker van t-PA niet anders aan de mannose receptor bond dan de hoog mannose-type suikers van ribonuclease $B$ en ovalbumine. Waarschijnlijk beinvloedt het eiwit van t-PA de conformatie van het hoog mannose-type suiker op t-PA zodanig dat de het suiker polymeer aan meerdere suiker herkenningsdomeinen van de mannose receptor kan binden waardoor intact t-PA een hoge affiniteit heeft voor de mannose receptor. De bindingsassay met geisoleerde humane mannose receptor werd in verdere studies als een in vitro meetsysteem gebruikt om de effectiviteit van remmers van de mannose receptor-t-PA binding te bepalen (zie hoofdstuk $3,6,7,8$ ). 
In hoofdstuk 2 werden de receptoren die verantwoordelijk zijn voor de binding, opname en afbraak van t-PA door gekweekte humane macrofagen gekarakteriseerd. Uit buffy coats van donor bloed, werden monocyten geïsoleerd en gekweekt. Binnen 2 dagen waren de monocyten gedifferentieerd tot macrofagen. t-PA bond bij $4^{\circ} \mathrm{C}$ met hoge $(\mathrm{Kd}=1-5 \mathrm{nM})$ en lage $(\mathrm{Kd}>350 \mathrm{nM})$ affiniteit aan de macrofagen. De lage affiniteits bindingsplaatsen waren rembaar met de lysine analoog 6-aminohexaan zuur (6-AHA). Bij $37^{\circ} \mathrm{C}$ werd t-PA opgenomen en afgebroken door de macrofagen Dit proces was gedeeltelijk rembaar met mannan of een monoclonaal antilichaam tegen de mannose receptor (zie hoofdstuk 3). Het niet mannan-rembare deel van de afbraak kon geblokkeerd worden met receptor associated protein (RAP), een remmer van de LRP. Inactivatie van t-PA noch toevoeging van 6-AHA had invloed op de afbraak van t-PA. De afbraak van t-PA door monocyten was niet rembaar met mannan. De mannose receptor- en LRP-gemedieerde t-PA afbraak werd hoger tijdens differentiatie van monocyt tot macrofaag. Wanneer de macrofagen gestimuleerd werden door dexamethason werd alleen de mannose receptor-gemedieerde afbraak verhoogd. Wanneer de macrofagen gestimuleerd werden met lipopolysaccharide werd de mannose receptor- en de LRP-gemedieerde t-PA afbraak verlaagd. We concludeerden dat humane macrofagen twee onafhankelijk gereguleerde receptoren, de mannose receptor en de LRP, gebruiken voor de opname en afbraak van t-PA. Gekweekte humane macrofagen zijn, aangezien vooral deze twee receptoren verantwoordelijk zijn voor de klaring van t-PA in de lever, een praktisch in vitro meetsysteem voor de evaluatie van t-PA klaringsremmers. In verdere studies werden deze macrofagen dan ook gebruikt om de effectiviteit van mannose receptorgemedieerde t-PA afbraak remmers te bepalen (zie hoofdstuk $3,7,8$ ).

\section{Ontwikkeling en toepassingen van monoclonal antilichamen tegen de humane mannose receptor}

Een set van 5 monoclonale antilichamen $(\mathrm{mAb})$ werd opgewekt tegen de mannose receptor geisoleerd uit humane placenta en gekarakteriseerd (hoofdstuk 3). Uit Western blots bleek dat alle mAb de $175 \mathrm{kD}$ mannose receptor in het ruwe placenta extract herkenden. Met behulp van immunohistochemie toonden we aan dat de mannose receptor in de placenta tot expressie gebracht wordt door de Hofbauer cellen (foetale macrofagen). Uit remmings experimenten bleek dat de mAb minstens twee verschillende epitopen op de geisoleerde mannose receptor herkenden. Een van deze epitopen ligt in de buurt van de bindingsplaats van t-PA, aangezien de mAb die dit epitoop herkenden, de binding van t-PA aan de geisoleerd mannose receptor en de mannose receptor-gemedieerde t-PA afbraak door macrofagen sterk konden remmen.

Deze mAb werden gebruikt om de mannose receptor expressie op geïsoleerde cellen en in lymfoide organen te bestuderen (hoofdstuk 4). Met behulp van flow cytometrie bleek dat geisoleerde humane monocyten en lymfocyten niet en gekweekte macrofagen wel de mannose receptor tot expressie brengen. Dexamethason behandelde macrofagen brachten meer mannose receptor tot expressie en lipopolysaccharide behandelde macrofagen brachten minder mannose receptor tot expressie. De mannose receptor expressie van een aantal celtypes die betrokken zijn bij de afweer werd bestudeerd met behulp van immunohistochemie (met mAb 15-2). Monocyten, lymfocyten, granulocyten en Langerhans cellen waren mannose receptor-negatief, weefsel macrofagen in thymus, lymfknopen, beenmerg en huid waren mannose receptor-positief. Opvallend was dat de macrofagen in thymus schors en de $T$ cel gebieden van de lymfknopen mannose receptor-positief waren, terwijl de macrofagen in de thymus merg en de $B$ cel gebieden van de lymfknopen mannose receptor-negatief waren. 
Monocyten kunnen zich differentieren tot antigen presenterende cellen (dendritische cellen). Bekend is dat de mannose receptor een rol speelt bij de opname van antigenen door dendritische cellen in vitro. Als deze cellen gestimuleerd worden om antigen te presenteren aan $T$ cellen, dan is de mannose receptor expressie verlaagd. Antigen presentatie vindt plaats in de thymus schors en in de B cel gebieden van lymfknopen en dit zou de afwezigheid van mannose receptor-positieve cellen in deze gebieden kunnen verklaren.

De mannose receptor is behalve bij de klaring van hoog mannose-type suikers bevattende eiwitten in de lever, ook betrokken bij andere processen. Uit in vitro experimenten is gebleken dat de mannose receptor betrokken is bij de complement onafhankelijke opname van pathogenen zoals Candida en Tuberculose, bij een afweerreactie tegen lichaamsvreemde stoffen waarbij macrofagen de mannose receptor waarschijnlijk gebruiken om te fuseren tot reuze cellen, bij de 'homing' van lymfocyten naar de milt, en bij de vruchtbaarheid van spermacellen. De mannose receptor expressie op macrofagen correleert met het type van macrofaag activatie in vitro; het T-helper type 1 cytokine $\gamma$-interferon activeert de macrofagen op zo'n manier dat de mannose receptor expressie wordt verlaagd, terwijl de T-helper type 2 cytokines interleukine- 4 en interleukine-13 de macrofagen op zo'n manier activeren dat de mannose receptor wordt verhoogd (ook wel immunosuppressie of alternatieve activatie genoemd).

Met behulp van één van de mAb (mAb 15-2) hebben we in hoofdstuk 5 de weefsel distributie van de mannose receptor in gezond en ziek menselijk weefsel geevalueerd. Slechts een klein aantal celtypes brengt de mannose receptor tot expressie in gezond weefsel; de residente macrofagen in alle weefsels, de sinusoidale endotheel cellen in de lever en milt, en de spermacellen. Sommige macrofagen waren mannose receptor-negatief: de microgliacellen in de hersenen en de macrofagen in de thymus schors en in de B cel gebieden van de milt en lymfknopen. In tuberculose, lepra, kanker of reumatoide arthritis aangetaste weefsels leek de mannose receptor expressie op macrofagen verlaagd te zijn wat aangeeft dat de macrofagen geactiveerd zijn, terwijl in een afweereactie tegen polyethyleen de mannose receptor expressie verhoogd leek te zijn wat aangeeft dat de macrofagen alternatief geactiveerd zijn. We hebben geconcludeerd uit deze studie dat de mannose receptor in vivo slechts door een aantal cellen tot expressie wordt gebracht, en dat de mannose receptor expressie ook in vivo correleert met het type van macrofaag activatie. mAb 15-2 bleek een specifiek middel om de mannose receptor expressie in weefsels aan te tonen.

\section{Remmers van de mannose receptor-gemedieerde t-PA klaring}

Een serie mannose receptor liganden werd gesynthetiseerd. Aan een skelet van lysine of polylysine werden, via flexibele tussenstukken, twee $\left(M_{2} L_{1}\right)$ tot zes eindstandige $\alpha$-D-mannose residuen $\left(M_{6} L_{5}\right)$ gekoppeld. De effectiviteit van deze 'cluster mannosides' om de t-PA of de ribonuclease B binding aan de geïsoleerde mannose receptor te remmen, werd getest (hoofdstuk 6). Alle cluster mannosides remden de binding van $t-P A$ of ribonuclease $B$ compleet. De affiniteit van de remmers nam toe met het aantal eindstandige mannose residuen dat aan het lysineskelet was gekoppeld $\left(M_{2} L_{1}\right.$ micromolair affiniteit, $M_{6} L_{5}$ nanomolair affiniteit). De vorm van de remmings curves gaf aan dat de clustermannosides aan meerdere suiker herkenningsdomeinen van de mannose receptor kunnen binden. De nanomolair affiniteit van $\mathrm{M}_{6} \mathrm{~L}_{5}$ maakt het tot het meest krachtige synthetische mannose receptor ligand tot nog toe ontwikkeld, en is behalve als remmer voor ligand binding aan de mannose receptor een vulbelovend middel om medicamenten (zoals gentherapeutica) specifiek af te leveren bij celtypes die de mannose receptor tot expressie brengen. 
In hoofdstuk 7 werd getest of deze cluster mannosides ook effectieve t-PA klaringsremmers in de mens zouden kunnen zijn. Allereerst toonden we met behulp van immunohistochemie aan dat, net zoals in de rattelever, in de humane lever de mannose receptor tot expressie wordt gebracht door lever sinusoidale endotheelcellen en Kupffercellen. De mannosides remden met vergelijkbare affiniteit de mannose receptor-gemedieerde t-PA binding, opname en afbraak door sinusoidale endotheelcellen geïsoleerd uit rattelevers en de t-PA opname en afbraak door gekweekte humane macrofagen. $M_{5} L_{4}$ remde $t-P A$ afbraak met micromolair affiniteit terwijl $M_{6} L_{5}$ de t-PA afbraak met nanomolair affiniteit remde. De concentraties nodig om t-PA afbraak in vitro te remmen waren vergelijkbaar met de concentraties nodig om t-PA klaring in vivo in de rat te remmen. Het is waarschijnlijk dat $M_{6} L_{5}$, zoals waargenomen in de rat, een efficiente remmer van de t-PA klaring in de mens zal zijn, aangezien er geen species verschil tussen de expressie van de mannose receptor in de lever en in de affiniteit van remming was.

In hoofdstuk 8 leveren we aanwijzingen dat mannose receptor remmers in vivo in de mens, mogelijk een antithrombotisch effect hebben. Dextran is een bloedvervanger met een antithrombotische werking. Recente studies hebben aangetoond dat dextran de plasma t-PA concentratie en activiteit verhoogt in patienten. Dextran is een glucose polymeer en een mogelijk ligand van de mannose receptor. We hebben het effect van dextran op de mannose receptor-t-PA interactie in onze beide in vitro modellen en in vivo in de rat getest. Bij therapeutische concentraties, bleek dextran in staat om de binding van tPA aan de geïsoleerde receptor, en de mannose receptor-gemedieerde t-PA afbraak door macrofagen te remmen, terwijl de LRP-gemedieerde t-PA afbraak onaangetast bleef. Dextran bleek in vivo endogene t-PA concentraties te verhogen en de klaring van exogeen t-PA te remmen. Tevens correleerde de endogene t-PA concentraties met de klaringssnelheid van exogeen t-PA. We concludeerden dat de dextran gemedieerde verhoging van endogene t-PA concentraties een gevolg is van de remming van de mannose receptor-gemedieerde t-PA klaring door dextran, hetgeen een nieuwe verklaring is voor het antithrombotische effect van dextran.

In hoofdstuk 9 werd de rol van de mannose receptor en andere klarings receptoren in de regulatie van tPA concentraties geevalueerd. Hierin concluderen we dat de plasmaklaring van t-PA voornamelijk gemedieerd wordt door de mannose receptor en de LRP in de lever. Het hoog mannose-type suiker van t-PA bindt aan de mannose receptor, terwijl het groeifactor- en het vinger-domein van t-PA betrokken zijn bij de binding aan LRP. De expressie van deze receptoren in de lever beinvloedt mogelijk de endogene plasma t-PA concentraties bij (patho)fysiologische condities zoals veroudering, zwangerschap, overgewicht en diabetes. Remmers van de (mannose receptor-gemedieerde) t-PA klaring zijn een mogelijkheid orn de effectiviteit van thrombolytische en antithrombotische therapie te verhogen. 


\section{Conclusies en toekomstperspectief}

In deze studie werden nuttige meetmodellen en middelen om de $175 \mathrm{kDa}$ mannose receptor te bestuderen, en hoge affiniteits liganden om zijn interactie met t-PA te remmen ontwikkeld. We toonden aan dat in menselijke weefsel de mannose receptor door macrofagen tot expressie wordt gebracht, en dat deze expressie afhankelijk is van het type van macrofaag activatie. De monoclonale antilichamen tegen de mannose receptor kunnen mogelijk nieuwe informatie verschaffen over de rol van macrofagen in verschillende ziekten. De mannose receptor op lever sinusoidale endotheelcellen en Kupffercellen speelt een belangrijke rol in de klaring van t-PA. Het bleek dat mannose receptor liganden/remmers de klaring van exogene t-PA gedeeltelijk konden remmen, en de endogene t-PA plasma concentratie konden verhogen. Mannose receptor remmers zoals $M_{6} L_{5}$ kunnen dus beschouwd worden als een nieuwe strategie om de t-PA concentratie in bloed te verhogen en daarmee de effectiviteit van thrombolytische en antithrombotische therapie te verhogen.

De in dit proefschrift beschreven mannose receptor liganden zouden behalve bij de behandeling van thrombotische aandoeningen in de toekomst misschien gebruikt kunnen worden bij de behandeling van andere ziektes. Men kan daarbij denken aan koppeling van medicijnen aan deze liganden om de medicijnen specifiek te sturen naar mannose receptor bevattende cellen (de sinusoidale cellen in de lever en milt, en de macrofagen en dendritische cellen in alle weefsels). Om vooral die cellen die zich buiten de bloedbaan bevinden te bereiken, zouden ligand-gekoppelde therapeutica in combinatie met dextran 70 (macrodex) gebruikt kunnen worden. Dextran 70 remt immers de mannose receptorgemedieerde klaring en is te groot om uit de bloedbaan ontsnappen. Op deze manier zouden therapeutica naar macrofagen en dendritische cellen gestuurd kunnen worden waardoor het mogelijk wordt om het afweersysteem te activeren of te onderdrukken. Men zou dan bijvoorbeeld het afweersysteem kunnen activeren om bepaalde celtypes te doden (zoals kankercellen of afweercellen die verkeerde antilichamen aanmaken), door dendritische cellen op te laden met antigenen van die celtypes. Het is een hoopvolle gedachte dat we in de toekomst misschien op deze manier in staat zullen zijn om het afweersysteem van het lichaam te manipuleren. 


\section{PUBLICATIONS}

F Noorman, DC Rijken.

Mannose receptor-mediated uptake and degradation of tissue-type plasminogen activator (t-PA) by human monocyte-derived macrophages.

Fibrinolysis 1992; 6 Suppl 2: 165. (abstract)

F Noorman, MM Barrett-Bergshoeff, CJM van Leuven, EAM Braat, R Bos, DC Rijken.

Monoclonal antibodies raised against the human mannose receptor inhibit t-PA degradation by human monocyte-derived macrophages.

Abstracts of papers presented at the 1993 meeting on Molecular \& Cellular Biology of Plasminogen Activation. Eds F Blasi, K Danø, J Quigley, D Rifkin, S Strickland. Cold Spring Harbor Laboratory, New York. pp 77. (abstract)

F Noorman, EAM Braat, DC Rijken.

Macrofagen breken t-PA af na opname via de mannose receptor en de low density lipoprotein receptor-related protein (LRP).

Trombose, Atherosclerose en ontsteking. 9e Amstol Symposium Amsterdam 1994. Eds. JW ten Cate, BM Bas, E Briët, SJH van Deventer, JJP Kastelein, H Pannekoek. Stichting Amstol, Leiden. pp 125-127.

F Noorman, EAM Braat, DC Rijken.

Degradation of tissue-type plasminogen activator by human monocyte-derived macrophages is mediated by the mannose receptor and by the low density lipoprotein receptor-related protein.

Blood 1995; 86: 3421-3427.

EAL Biessen, F Noorman, ME van Teijlingen, J Kuiper, MM Barrett-Bergshoeff, MK Bijsterbosch, DC Rijken, ThJC van Berkel.

Lysine-based cluster mannosides that inhibit ligand binding to the human mannose receptor at nanomolar concentration.

Journal of Biological Chemistry 1996; 271: 28024-28030.

F Noorman, EAM Braat, MM Barrett-Bergshoeff, E Barbé, A van Leeuwen, J Lindeman, DC Rijken. Monoclonal antibodies against the human mannose receptor as a specific marker in flow cytometry and immunohistochemistry for macrophages.

Journal of Leukocyte Biology 1997; 61: 63-72.

MM Barrett-Bergshoeff, F Noorman, R Bos, DC Rijken.

Monoclonal antibodies against the human mannose receptor that inhibit the binding of tissuetype plasminogen activator.

Thrombosis and Haemostasis 1997; 77: 718-724. 
F Noorman, MM Barrett-Bergshoeff, EAL Biessen, ThJC van Berkel, DC Rijken.

Cluster mannosides can inhibit mannose receptor-mediated tissue-type plasminogen activator degradation by both rat and human cells.

Hepatology 1997, in press.

F Noorman, MM Barrett-Bergshoeff, M Bekkers, JJ Emeis, DC Rijken.

Inhibition of mannose receptor-mediated clearance of tissue-type plasminogen activator (t-PA) by dextran: a new explanation for its antithrombotic effect.

Thrombosis and Haemostasis 1997; Suppl; pp 745-746. (abstract)

F Noorman, MM Barrett-Bergshoeff, M Bekkers, JJ Emeis, DC Rijken.

Inhibition of mannose receptor-mediated clearance of tissue-type plasminogen activator (t-PA) by dextran: a new explanation for its antithrombotic effect.

Thrombosis and Haemostasis 1997, in press.

F Noorman, DC Rijken.

Regulation of tissue-type plasminogen activator (t-PA) concentrations by clearance via the mannose receptor and other receptors.

Fibrinolysis and Proteolysis 1997, in press.

F Noorman, MM Barrett-Bergshoeff, DC Rijken.

Role of carbohydrate in the binding of tissue-type plasminogen activator (t-PA) to the human mannose receptor.

Submitted.

F Noorman, E Barbé, A van Leeuwen, J Lindeman, DC Rijken.

Expression of the human mannose receptor under physiological and pathological conditions. An immunohistochemical study using monoclonal antibody 15-2.

Submitted. 


\section{CURRICULUM VITAE}

Femke Noorman werd geboren op 15 september 1966 te Hengelo. In 1984 beëindigde zij het Gymnasium Juvenaat Heilig Hart te Bergen op Zoom en ging Biologie studeren aan de Rijksuniversiteit te Utrecht. Na het behalen van de propadeuse Biologie en het afronden van de eerste subfase van deze studie, studeerde zij van 1987 tot 1990 Bio-Farmaceutische Wetenschappen (BFW) aan de Rijksuniversiteit Leiden. In het laatste jaar van deze studie heeft zij als hoofdvak (gesubsidieerd door het Platform Alternatieven voor Proefdieren) bij de afdeling Toxicologie van BFW (o.l.v. Dr. J.F. Nagelkerke en Prof. Dr. G.J. Mulder) varken- en mensen- niercelkweken opgezet om in vitro niertoxiciteit te kunnen meten. In augustus 1990 behaalde zij het doctoraalexamen. Vervolgens heeft zij gewerkt als chemisch analiste bij de apotheek van het St. Elisabeth Ziekenhuis te Leiderdorp en als medewerker bij de afdeling Biofarmacie van BFW (o.I.v. Dr. J. Kuiper en Prof. Dr. Th.J.C. van Berkel). Vanaf september 1991 is zij werkzaam geweest als assistent in opleiding bij de afdeling Vaat-en Bindweefsel Onderzoek van het Gaubius Laboratorium, TNO Preventie en Gezondheid, te Leiden. Onder leiding van Dr. D.C. Rijken en Prof. Dr. P. Brakman werd het promotieonderzoek (gesubsidieerd door de Nederlandse Hartstichting) uitgevoerd zoals in dit proefschrift beschreven is. 


\section{NAWOORD}

Graag wil ik alle collega's bij het Gaubius Laboratorium van TNO-PG, de afdeling Biofarmacie van het Leiden/Amsterdam Center for Drug Research en de afdeling Pathologie van het Slotervaart Ziekenhuis in Amsterdam, familieleden en vrienden bedanken voor hun bijdrage aan het tot stand komen van dit proefschrift. De volgende mensen wil ik in het bijzonder bedanken: Dick, Marrie, Ellen, Erik en Ellis voor hun aandeel in het werk, Helen voor de engelse correcties, Jaap voor de goede verzorging van Noppes de geit, Ria, Monique en Jan voor gezelligheid en inspiratie, en mijn ouders en Xris voor hun niet aflatende morele steun. 


\section{APPENDIX}

\section{Coloured figures belonging to chapter 3,5 and 7}

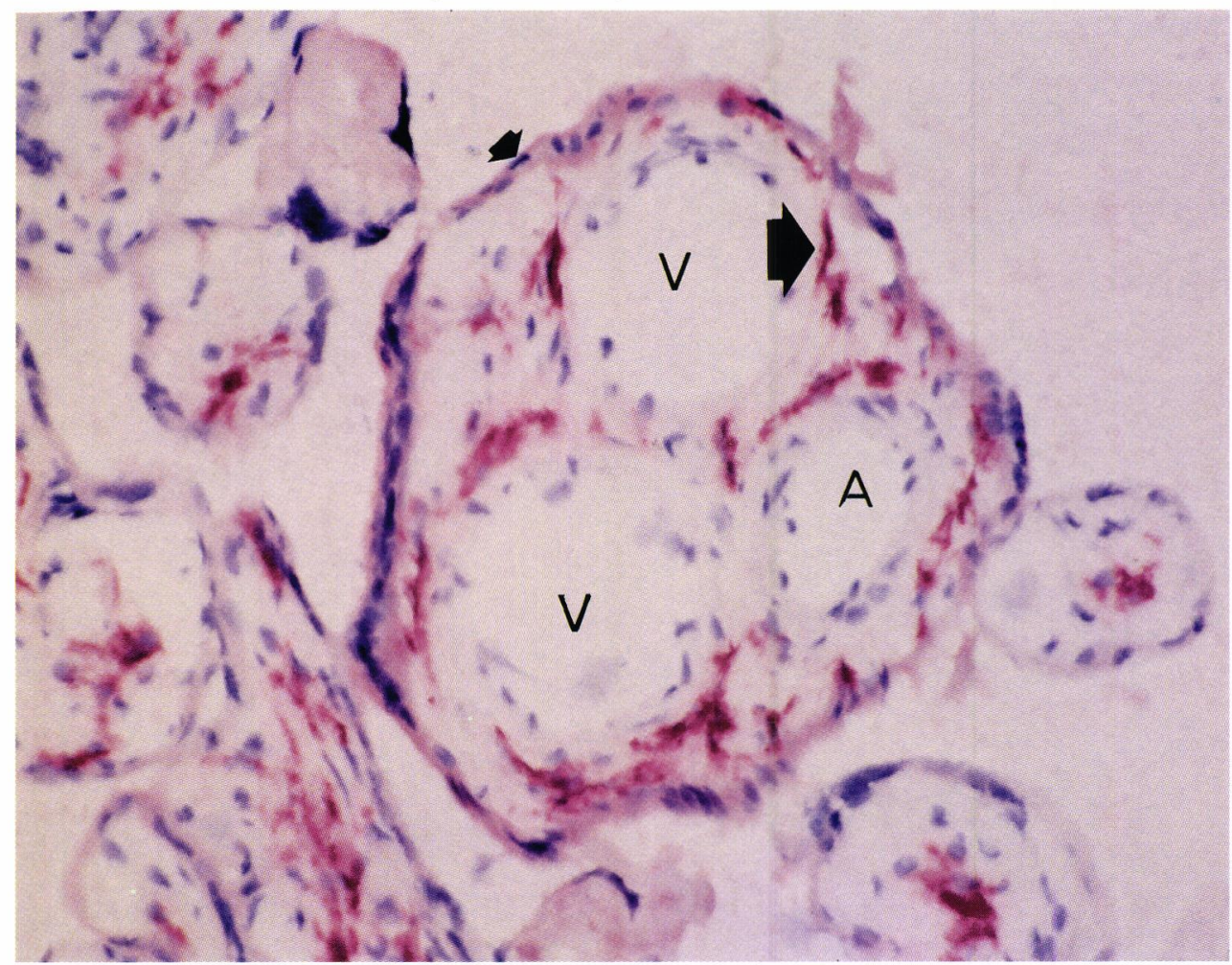

\section{Figure belonging to chapter 3;}

Monoclonal antibodies against the human mannose receptor that inhibit the binding of tissue-type plasminogen activator. Thrombosis and Haemostasis 1997; 77:718-724

Fig 2 Immunohistochemical staining of the mannose receptor in human placenta.

Typical staining pattern (by use of mAb 15-2) of a cryostat section of human placenta. In the middle a cross section of a chorionic villus is shown. In the periphery of the villus the mannose receptor negative syncytiotrophoblasts (small arrow) are located that form the interface between maternal blood and fetal tissue. In the centre of the villus one can discriminate one artery (A) and two venules (V) surrounded by a stroma where the mannose receptor positive (intense red staining, large arrow) Hofbauer cells are located. 

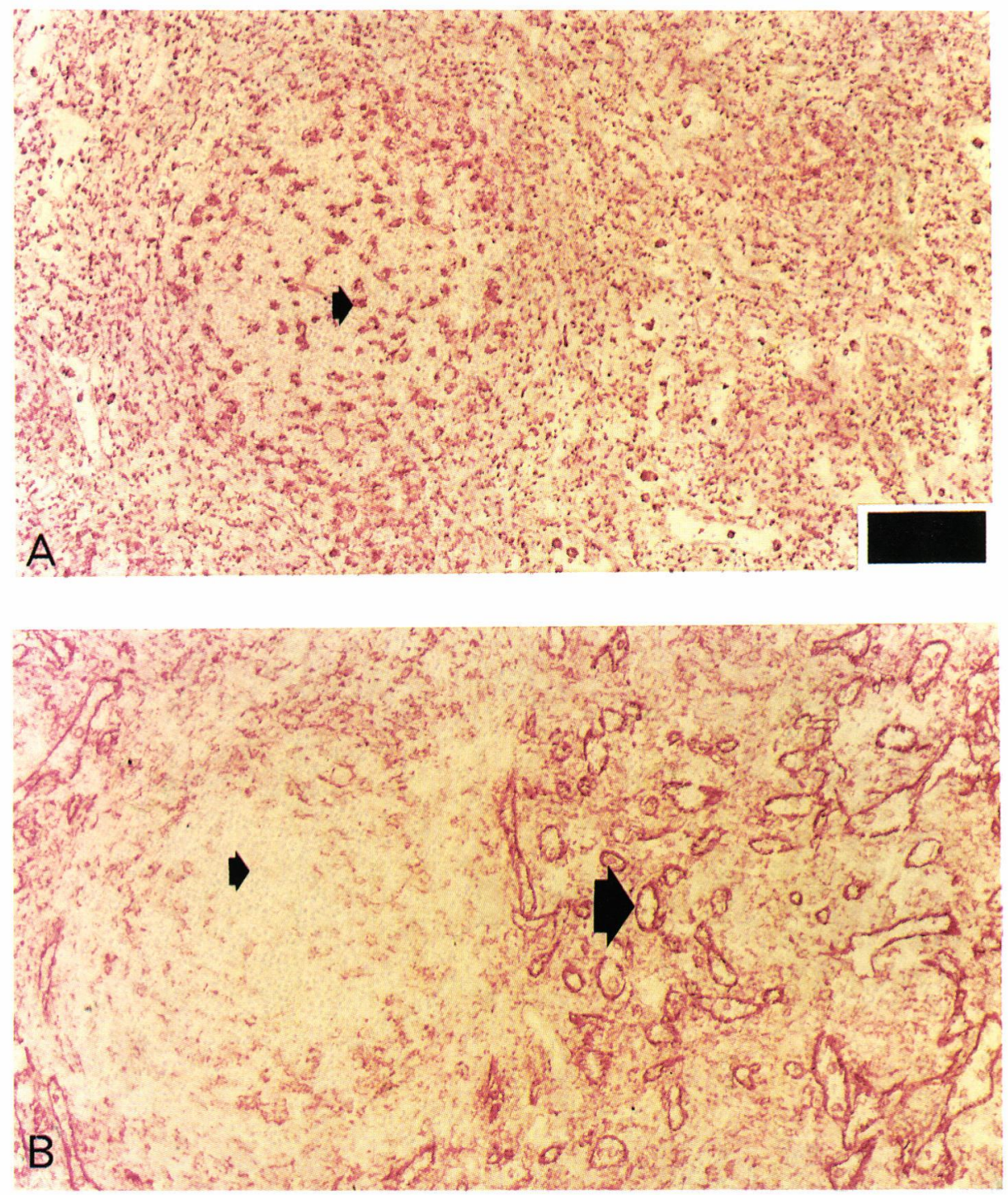

Figure belonging to chapter 5;

Expression of the human mannose receptor under physiological and pathological conditions; An immunohistochemical study using monoclonal antibody 15-2. (submitted)

\section{Fig 1A-B Mannose receptor and CD68 expression in tissue under physiological conditions.}

The distribution of CD68 (A) and the mannose receptor (B) in spleen. Bar represents $400 \mu \mathrm{m}$.

In the spleen, the macrophages inside the germinal centres (follicular dendritic cells, small arrow) were CD68 positive. In this area only few cells were mannose receptor-positive (small arrow). The splenic sinusoidal endothelial cells however abundantly express the mannose receptor (large arrow). 

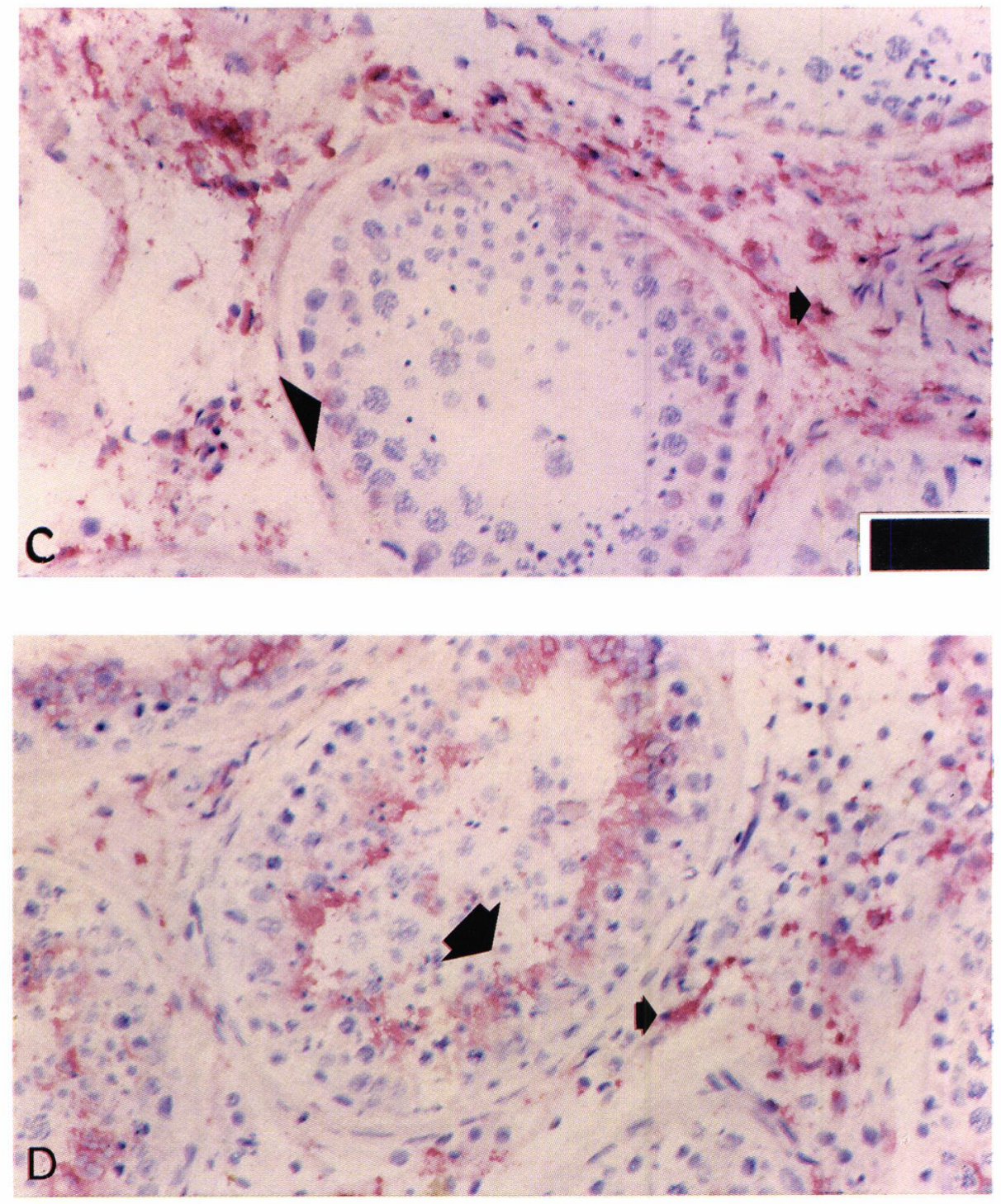

Figure belonging to chapter 5 ;

Expression of the human mannose receptor under physiological and pathological conditions; An immunohistochemical study using monoclonal antibody 15-2. (submitted)

Fig 1C-D Mannose receptor and CD68 expression in tissue under physiological conditions.

The distribution of CD68 (C) and the mannose receptor (D) in testis. Bar represents $200 \mu \mathrm{m}$.

In the testis, the resident macrophages surrounding the tubuli were mannose receptor- and CD68-positive (small arrow). The Leydig cells were CD68-positive (arrowhead) and mannose receptor-negative, whereas the spermatids and spermatozoa (large arrow) inside the seminoferous tubuli were mannose receptor-positive and CD68-negative. 

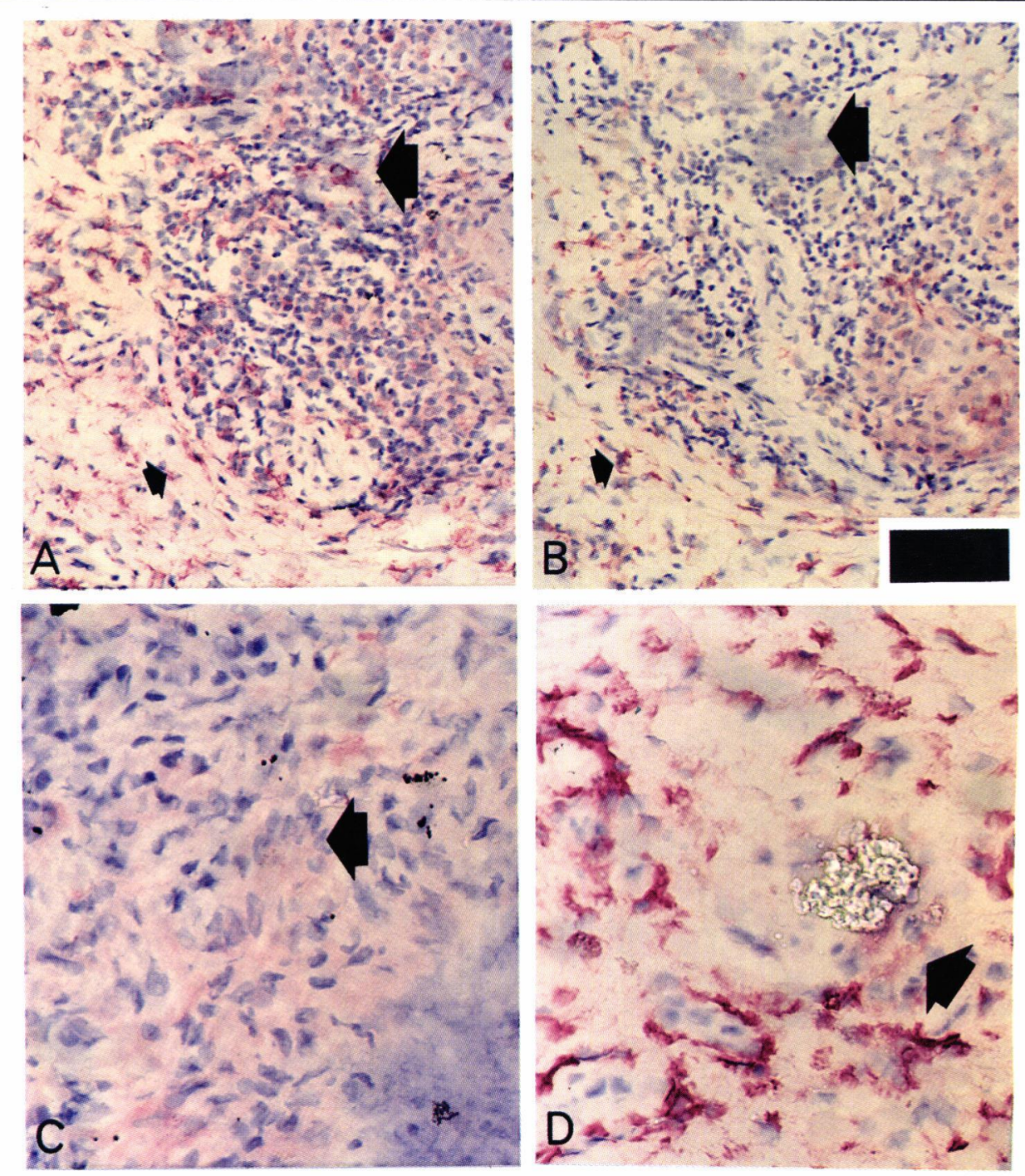

\section{Figure belonging to chapter 5;}

Expression of the human mannose receptor under physiological and pathological conditions; An immunohistochemical study using monoclonal antibody 15-2. (submitted)

Fig 2A-D Mannose receptor and CD68 expression in tissue under pathological conditions.

Tissues under various pathological conditions were stained with KP-1 (A) or mAb 15-2 (B,C,D). Bar represents 200 $\mu \mathrm{m}(\mathbf{A}, \mathbf{B})$ or $100 \mu \mathrm{m}(\mathbf{C}, \mathbf{D})$

The edge of a granuloma of skin affected by tuberculoid leprosy is shown (A,B). Unaffected skin tissue contained CD68-positive (A) and mannose receptor-positive (B) resident macrophages (small arrow). Inside the granulomas CD68-positive (A) and few weakly mannose receptor-positive macrophages (B) were present. The Langhans-type giant cells (large arrow) were slightly CD68-positive and mannose receptor-negative. Giant cells in tuberculosis affected lung (C), and in the synovium affected by a foreign body reaction (D) stained weakly with mAb 15-2 (large arrow). The macrophages surrounding the Langhans-type giant cells (C) also only weakly stained with mAb 15-2, whereas the macrophages surrounding the foreign body-type giant cells strongly stained with mAb 15-2 (D). 

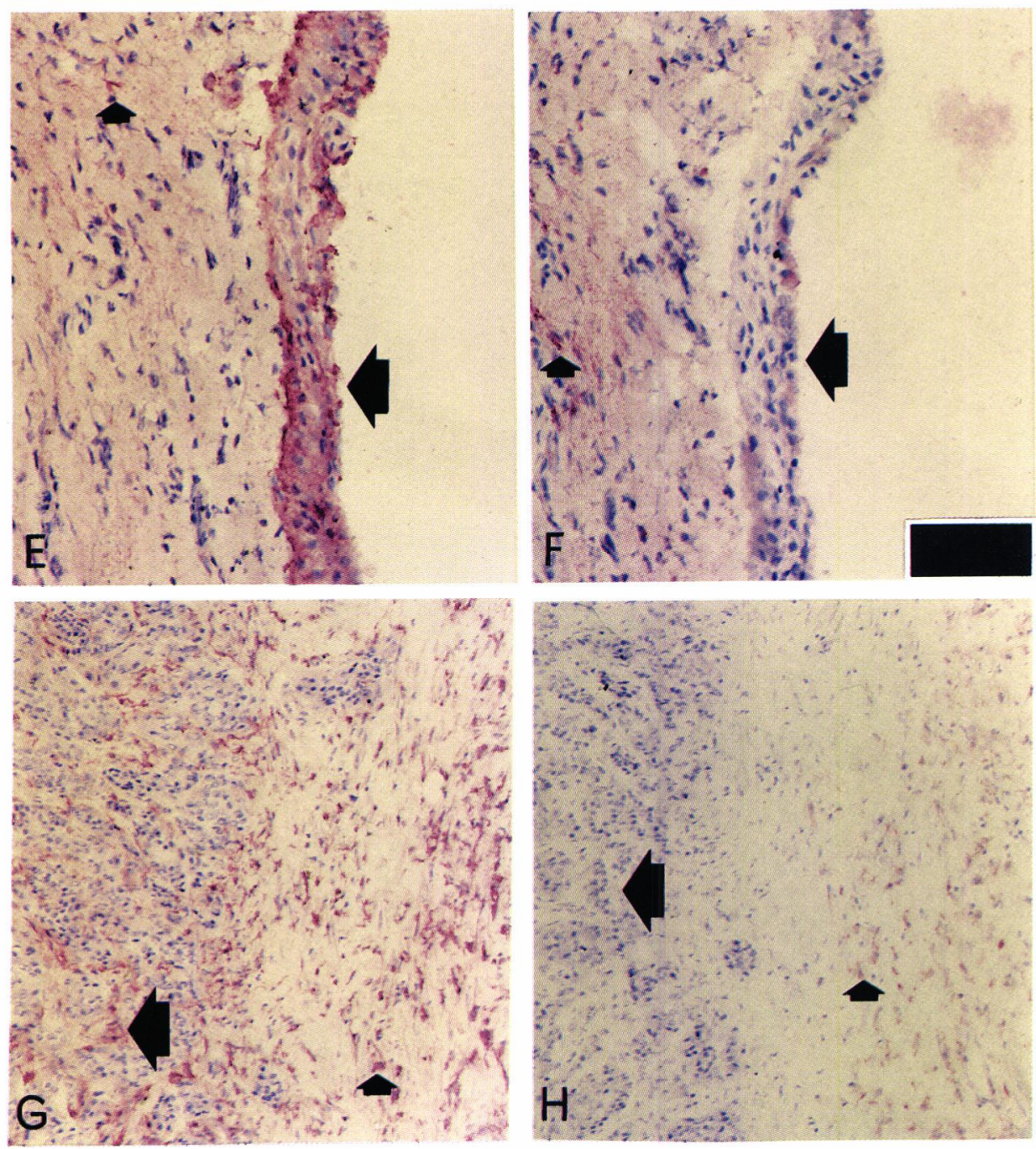

\section{Figure belonging to chapter 5 ;}

Expression of the human mannose receptor under physiological and pathological conditions; An immunohistochemical study using monoclonal antibody 15-2. (submitted)

Fig 2E-H Mannose receptor and CD68 expression in tissue under pathological conditions.

Tissues under various pathological conditions were stained with KP-1 (E,G) or mAb 15-2 (F,H). Bar represents 200

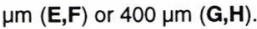

In a synovium affected by rheumatoid arthritis most of the hypertrophic and hyperplastic synovial lining cells (large arrow) were CD68positive $(E)$ and mannose receptor-negative $(F)$, whereas the stromal macrophages were CD68- and mannose receptor-positive (small arrow). In breast affected by cancer (ductal type) normal stroma macrophages (small arrow) still expressed the CD68 antigen (G) and the mannose receptor $(\mathbf{H})$. Inside the desmoplastic tumor stroma the macrophages were mannose receptor-negative and CD68-positive (large arrow). 

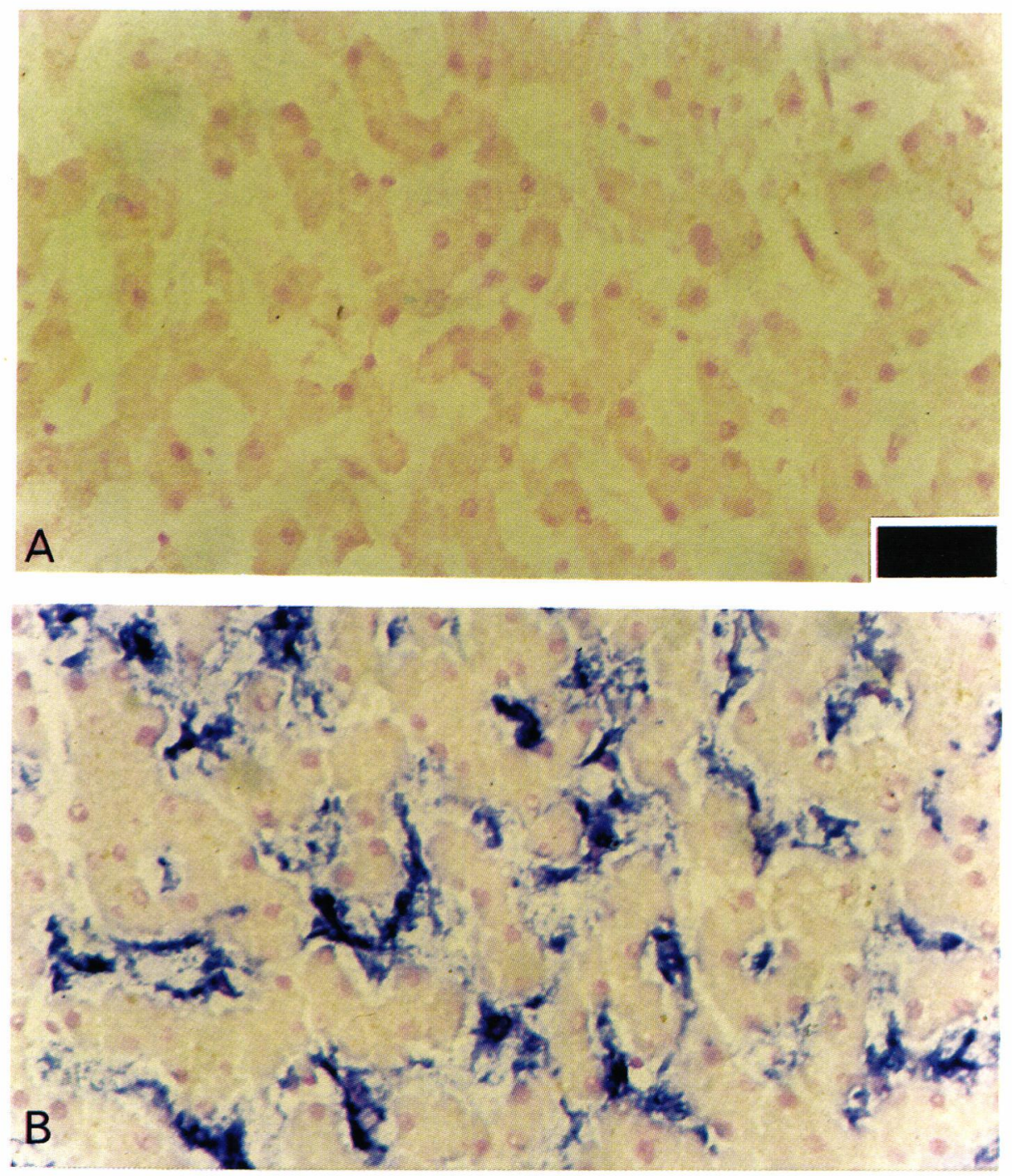

\section{Figure belonging to chapter 7;}

Cluster mannosides can inhibit mannose receptor-mediated tissue-type plasminogen activator (t-PA) degradation by both rat and human cells. Hepatology 1997, in press.

Fig 1A,B The presence of mannose receptor on human liver endothelial cells and Kupffer cells.

Representative area of a cryostat section of human liver stained without (A) or with (B) anti-mannose receptor monoclonal antibody 15-2 (blue) (both with red nuclear staining). Bar represents $100 \mu \mathrm{m}$ (light microscope; magnification x40). 

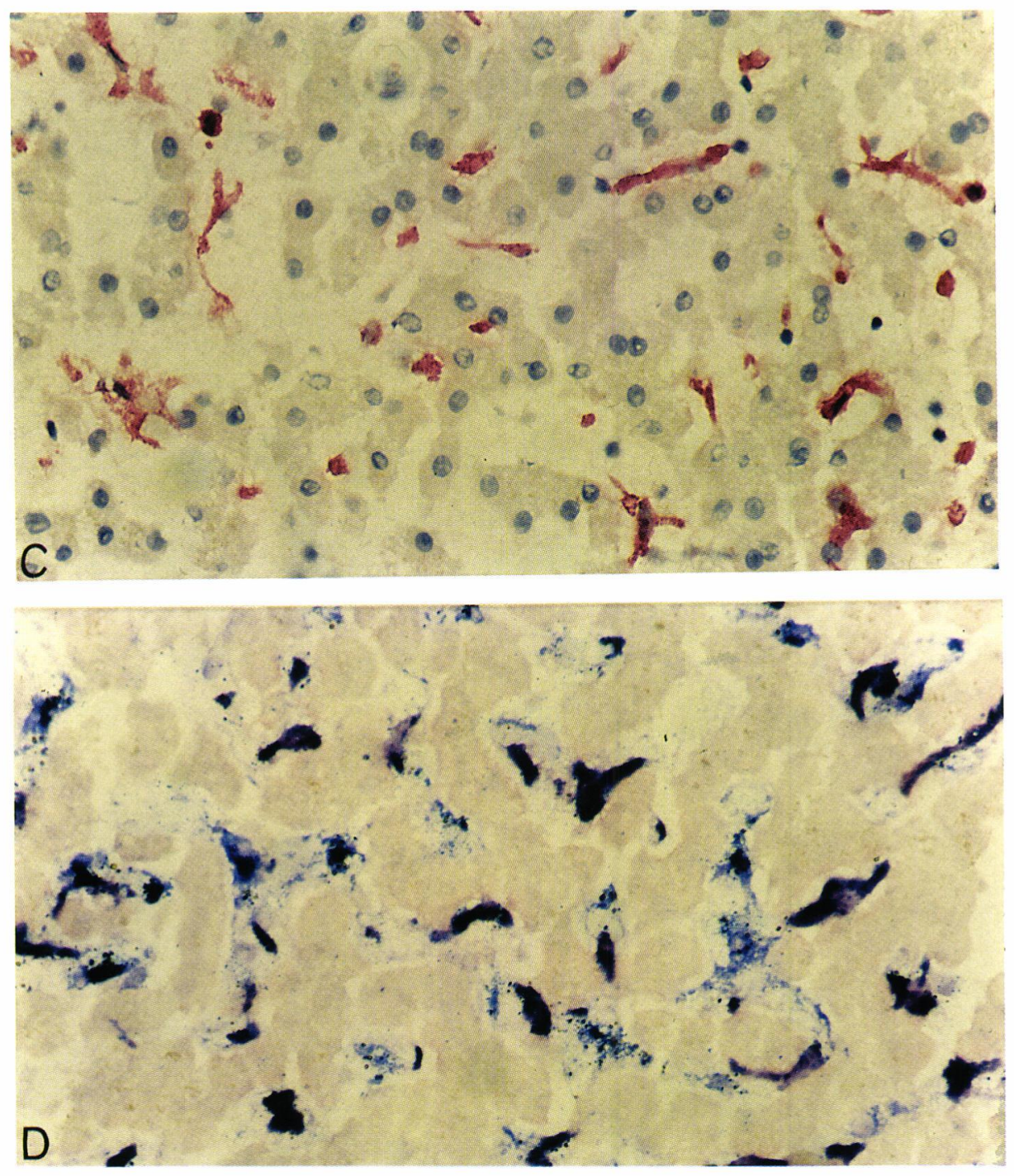

\section{Figure belonging to chapter 7;}

Cluster mannosides can inhibit mannose receptor-mediated tissue-type plasminogen activator (t-PA) degradation by both rat and human cells. Hepatology 1997, in press.

Fig 1C,D The presence of mannose receptor on human liver endothelial cells and Kupffer cells.

Representative area of a cryostat section of human liver stained with (C) anti CD68 monoclonal antibody KP-1 (red) (blue nuclear staining). The double staining with (D) KP-1 (red) plus mAb 15-2 (blue) (no nuclear staining) shows that sinus liver endothelial cells are mannose receptor-positive and CD68-negative (blue), and the Kupffer cells are both CD68- and mannose receptor-positive (purple). 


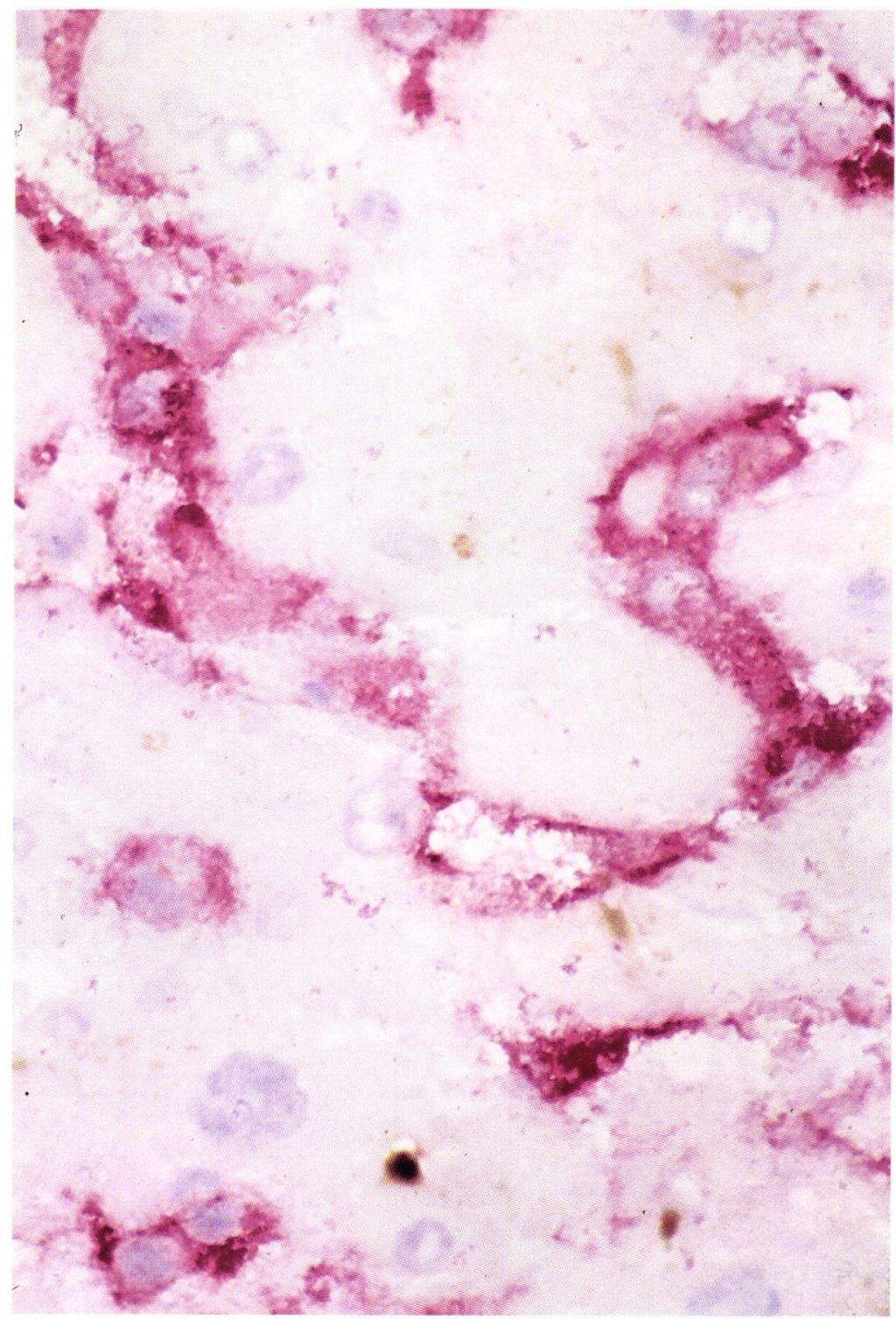

\section{Mannose receptor staining in the human liver with mAb 15-2.}

This picture was used for the design of the cover of this thesis. Both Kupffer cells and liver sinusoidal cells express the mannose receptor and stain intensely red with mAb 15-2. The staining procedure was the same procedure as used for the staining of the mannose receptor in the placenta (chapter 3). Because it is difficult to discriminate between the Kupffer cells and the sinusoidal endothelial cells we performed a double staining in Hepatology (see the pictures on page 148,149). 